University of Denver

Digital Commons @ DU

Marketing: Faculty Scholarship

Marketing

$5-2020$

\title{
Conceptualizing the Electronic Word-of-mouth Process: What we Know and Need to Know about eWOM Creation, Exposure, and Evaluation
}

\author{
Ana Babić Rosario \\ University of Denver \\ Kristine de Valck \\ HEC Paris \\ Francesca Sotgiu \\ HEC Paris
}

Follow this and additional works at: https://digitalcommons.du.edu/marketing_fac

Part of the Marketing Commons, and the Other Business Commons

\section{Recommended Citation}

Babić Rosario, Ana; de Valck, Kristine; and Sotgiu, Francesca, "Conceptualizing the Electronic Word-ofmouth Process: What we Know and Need to Know about eWOM Creation, Exposure, and Evaluation" (2020). Marketing: Faculty Scholarship. 1.

https://digitalcommons.du.edu/marketing_fac/1

This Article is brought to you for free and open access by the Marketing at Digital Commons @ DU. It has been accepted for inclusion in Marketing: Faculty Scholarship by an authorized administrator of Digital Commons @ DU. Formore information, please contact jennifer.cox@du.edu,dig-commons@du.edu. 


\section{Conceptualizing the Electronic Word-of-mouth Process: What we Know and Need to Know about eWOM Creation, Exposure, and Evaluation}

\section{Publication Statement}

This is an Accepted Manuscript of:

Babić Rosario, A., de Valck, K., \& Sotgiu, F. (2020). Conceptualizing the electronic word-of-mouth process: What we know and need to know about eWOM creation, exposure, and evaluation. Journal of the Academy of Marketing Science, 48, 422-448. https://doi.org/10.1007/s11747-019-00706-1

Copyright held by the Academy of Marketing Science. User is responsible for all copyright compliance. 


\title{
Conceptualizing the electronic word-of-mouth process:
}

\section{What we know and need to know about eWOM creation, exposure, and evaluation}

October 2019

\author{
Forthcoming in the Journal of the Academy of Marketing Science \\ Ana Babić Rosario \\ Kristine de Valck \\ Francesca Sotgiu
}

Ana Babić Rosario is Assistant Professor of Marketing at the University of Denver, email: ana.babic-rosario@du.edu. Kristine de Valck is Associate Professor of Marketing a HEC Paris, email: devalck@hec.fr. Francesca Sotgiu is Associate Professor of Marketing at Vrije Universiteit Amsterdam, email: f.sotgiu@vu.nl. Some of the research was conducted when Ana Babić Rosario was a doctoral student at the Department of Marketing at HEC Paris, and an earlier version of this article is part of Ana Babić Rosario's doctoral dissertation. The authors thank Michael Haenlein, Ko de Ruyter, Donald Bacon, and the participants of the 2017 INFORMS Marketing Science, 2018 BI-JAMS Thought Leaders', and 2019 AMA Winter conferences for their constructive feedback on earlier versions of this work, as well as Daniel Zheng and Stephanie Panozzo for valuable research assistance. The authors gratefully acknowledge the financial support of the HEC Foundation (F1307), Labex ECODEC (Investissements d'Avenir ANR-11-IDEX-0003/ Labex Ecodec/ ANR-11-LABX-0047), and the University of Denver's Internationalization Office (grants 86587-150401 and 86849-150401). The authors also thank the JAMS review team for their very constructive comments. Address correspondence to Ana Babić Rosario. 


\title{
Conceptualizing the electronic word-of-mouth process: What we know and need to know about eWOM creation, exposure, and evaluation
}

\begin{abstract}
Electronic word of mouth (eWOM) is a prevalent consumer practice that has undeniable effects on the company bottom line; yet it remains an over-labeled and under-theorized concept. Thus, marketers could benefit from a practical, science-based roadmap to maximize its business value. Building on the consumer motivation-opportunity-ability framework, this study conceptualizes three distinct stages in the eWOM process: eWOM creation, eWOM exposure, and eWOM evaluation. For each stage, we adopt a dual lens—-from the perspective of the consumer (who sends and receives eWOM) and that of the marketer (who amplifies and manages eWOM for business results) — to synthesize key research insights and propose a research agenda based on a multi-disciplinary systematic review of 1,050 academic publications on eWOM published between 1996 and 2019. We conclude with a discussion of the future of eWOM research and practice.
\end{abstract}

Keywords: Electronic word of mouth (eWOM); motivation, opportunity, ability (MOA) framework; eWOM process; eWOM creation; eWOM exposure; eWOM evaluation; systematic review; research agenda 


\section{Introduction}

More than 60 years after its introduction to the literature (Brooks 1957), word of mouth (WOM) has been revitalized and given new significance by means of the Internet (Dellarocas 2003). The proliferation of digital technologies has enabled consumers to share their consumption-related opinions, thereby creating electronic WOM (eWOM)—a “statement made by potential, actual, or former customers about a product or company, which is made available to a multitude of people and institutions via the Internet” (Hennig-Thurau et al. 2004, p. 39). These technologies have further amplified the importance of WOM as a buying influence. On Yelp alone, for example, 186 million people post nearly 150 million business reviews each month on which $90 \%$ of consumers rely for buying decisions (Capoccia 2018). Yet marketers are still struggling to maximize the business value of eWOM (Liousas 2018).

Despite the vast increase of eWOM research in the past two decades (see Lamberton and Stephen 2016), insights have accumulated in different directions, providing fragmented evidence on the meaning and market implications of this phenomenon. Why are eWOM conceptualization and assessment so challenging? To begin with, eWOM has been used to denote different online phenomena, as evidenced in the proliferation of conceptual labels across academic studies and among marketing practitioners. Depending on the research perspective, scholars have used different labels, including “sentiment,” for work on consumer attitudes, and “user-generated content (UGC),” in the information systems literature. In addition, certain aspects of eWOM are emphasized with specific conceptual labels, such as consumer knowledge (e.g., "amateur rating”), the facilitator role of marketers (e.g., Amazon.com “Like”), the consumption aspect (e.g., "product review”), or contextual characteristics (e.g., “tweet,” "brand community”). These 
different labels highlight a fragmented academic discourse and the need to distinguish eWOM from related concepts that may be mislabeled as eWOM.

Further complicating the academic debate on eWOM is consumers' dual role in the eWOM exchange. Consumers may progress along the eWOM communication process, moving from the eWOM creation, to exposure, to evaluation stages, acting at times as senders and at other times receivers of eWOM and shifting between these stages and roles in a non-linear way (Kannan and Li 2017). To date, most research has focused on one of these roles at a time and on consumers' motivations behind sending and receiving eWOM. However, the impact of any communication process, including that of eWOM, depends not only on consumers' motivations but also on their opportunities and abilities (MOA; Batra and Keller 2016; MacInnis et al. 1991). A framework that integrates consumers' dual role in the eWOM process and their MOA along this process can help marketers understand (1) when and how to facilitate consumers' MOA (e.g., by incentivizing the creation of eWOM) and (2) how to shape the outcome of the MOA on both eWOM senders (e.g., eWOM volume, valence, credibility) and eWOM receivers (e.g., buying influence, business value).

Marketing research needs a unifying effort to organize and discuss key research insights, emerging trends, and avenues for further research. The current study takes a step in this direction. First, we reflect on the different definitions and labels of eWOM to clarify what eWOM is and what it is not. Second, we propose an organizing framework that accounts for the dual role of consumers (senders, receivers) and their MOA in the eWOM process. Building on the vast body of eWOM literature, for each stage we summarize consumers' MOA and identify the most effective strategies for marketers. We are guided by four research questions: (1) What is eWOM? (2) What do consumers experience in the eWOM process? (3) How can marketers 
support the consumer and amplify the business value of eWOM? and (4) What remains to be known about the process, antecedents, and consequences of eWOM?

To address these questions and develop a research agenda on eWOM, we take stock of academic articles published between 1996 and 2019 and survey the main research findings on consumers' MOAs in terms of creating, being exposed to, and evaluating eWOM as well as the implications of these findings for marketing practice. In the remainder of the article, we detail the methodology, the eWOM concept, and the organizing framework. We then present what we know and need to know along the three-stage eWOM process, providing recommendations for scholars and marketers.

\section{Methodology}

We searched for published studies on eWOM in scientific databases (e.g., Business Source Premier, Google Scholar, JSTOR) using keywords, including “buzz,” “consumer-generated content," “electronic word of mouth,” “online review," “online word of mouth,” “social earned media,” and “user-generated content.” We included publications across several fields of research and applied a snowballing procedure by examining publications’ references to find additional studies. Finally, we searched for articles that use netnographic data (even if they do not refer to eWOM explicitly), as this method helps investigate consumer-to-consumer interactions in online communities (Kozinets 2016). We focused on research that (1) specifically investigates eWOM (e.g., antecedents, consequences), (2) employs eWOM as a crucial part of data collection (e.g., investigation of fashion blogs), (3) discusses technological or methodological advances that enable the study of eWOM (e.g., netnography), and (4) focuses on consumption-related, consumer-generated online content. Thus, we excluded articles that investigate purely marketergenerated online communication (e.g., online advertising); offline interactions such as offline 
WOM, complaints, and face-to-face brand communities; recommendations by critics, experts, and celebrity endorsers; and phenomena not related to consumption (e.g., general conversation topics, social media usage). Our final sample consists of 1,050 articles published between 1996 and 2019 in 86 different publication outlets (see Web Appendices 1 and 2), 59\% of which pertain to marketing and consumer research, $23 \%$ to information systems and computer science, $11.5 \%$ to economics and management, and $6.5 \%$ to tourism.

We performed a content analysis (Webster and Watson 2002). In addition to the descriptive information for each article (e.g., year of publication, research discipline), we coded the conceptual labels and definitions of eWOM used by authors, key theoretical approaches, research methodology, consumer MOAs in terms of participating in the eWOM exchange (as either senders or receivers), stage of the eWOM process (creation, exposure, or evaluation), characteristics of the eWOM exchange (source, message, channel, and audience), and key findings and implications.

\section{The concept and theoretical underpinnings of eWOM}

The literature provides a plethora of definitions and theorizations of eWOM that differ in scope and reference to particular elements of the eWOM exchange, i.e., the message, source, receiver, and channel (see Table 1). Liu’s (2006) definition of buzz, for example, stresses eWOM participants, but not the digital context; Dhar and Chang’s (2009) definition of UGC emphasizes the opposite. The different facets of the eWOM exchange are reflected not only in the many eWOM definitions but also in the 390 eWOM conceptual labels used, such as buzz, UGC, online reviews, and consumer-to-consumer know-how exchange (for an overview of the research evolution and major milestones in eWOM research, see Web Appendix 3; for the complete list of labels, see Web Appendix 4). 
--- Insert Table 1 about here ---

\section{Lack of clarity on the meaning of eWOM}

As evidenced in Table 1, eWOM is sometimes implied at the mere mention of certain platforms (e.g., virtual communities; Kozinets 1999), actions (e.g., virality, diffusion, online sharing), and data collection methods (e.g., netnography). When explicitly mentioned, eWOM is often used outside the marketing and consumer context to denote a general way of sharing information from person to person, rather than any consumer-generated content with commercial implications (e.g., Daugherty et al. 2008). We argue that any online consumer-generated content about products, even if far from a direct recommendation to other consumers, should be recognized as eWOM. To advance the holistic understanding of the phenomenon, we contend that "eWOM" can serve as an umbrella term to denote online consumer-generated content.

However, it is necessary to first clarify the concept of eWOM by distinguishing its essential properties from those of related concepts: (1) sharing general information, (2) offline WOM, (3) critics' reviews, (4) advertising, (5) UGC, (6) electronic recommendation systems, (7) online search rankings, and (8) observational learning. Confusing eWOM with any of these concepts or using them interchangeably may impair the retrieval and comparison of findings across publications and hinder progressive knowledge building (MacInnis 2011).

eWOM is not a form of sharing general information. eWOM is more specific than a broadly conceptualized channel for content transmission, which may, but does not need to, have commercial implications. Prior work has examined mechanisms such as email transmission (Rapp et al. 2013) and controversial conversation topics (Chen and Berger 2013). While insights from these studies may have implications for the eWOM phenomenon, the content investigated therein should not be equated with eWOM. 
eWOM is not offline WOM. The differences between eWOM and traditional WOM have been extensively discussed (e.g., Berger 2014; Hennig-Thurau et al. 2015; Lovett et al. 2013) and can be summarized along four elements. First, the communication network in eWOM is larger than that of traditional WOM because eWOM extends its reach via the Internet. Second, eWOM eliminates the restrictions on time and location, as asynchronous information is usually kept online for some time (Hoffman and Novak 1996). This has expanded the scope of eWOM communication from consumer-to-consumer exchanges to a broader phenomenon that includes online consumer-generated communication directed at marketers but visible to other consumers (Kim and Slotegraaf 2015). Third, whereas traditional WOM refers to mostly spoken or written formats, eWOM takes place in many other formats, and this has implications for information processing and adoption (Schweidel and Moe 2014). Fourth, eWOM is embedded in an online context whose idiosyncrasies shape its credibility and effectiveness (Babić Rosario et al. 2016). eWOM is not critics' reviews. It is important to distinguish between eWOM and critics' reviews. Simply put, consumers generate eWOM, whereas critics' reviews are largely provided by independent, third-party experts. The recognized expertise of critics amplifies the credibility of their message, leading to a significantly greater impact than that of eWOM on consumers' purchase decision (Floyd et al. 2014). Some confusion may arise from using terminology typical of consumer-generated information (e.g., "online buzz,” “online reviews”) for critics’ and experts' reviews. In addition, the rise of influencer marketing is blurring the distinction between regular consumers and critics as some influencers turn their hobby into a business generating income by professionally reviewing. We contend that paid influencers' reviews should be considered a form of advertising (see below) rather than eWOM. 
eWOM is not advertising. While marketer-generated messages and paid advertisements can spark eWOM (Dichter 1966), they are conceptually different from eWOM because they are not originally generated by consumers and are commercial in nature (Tellis et al. 2019). When consumers share advertisements, these may "go viral," that is, be shared by a large number of others (Akpinar and Berger 2017). In general, this act of sharing, liking, or commenting on an advertisement can be considered part of the eWOM phenomenon.

eWOM is not UGC. UGC is a broad concept that refers to any content created by users and primarily distributed on the Internet (Daugherty et al. 2008). By contrast, eWOM is necessarily consumption-related. For example, eWOM does not include communication that merely reflects people's moods or expressions that are not related to products, brands, companies, or consumption experiences. This is important because some research investigating the effects of UGC (e.g., Lee and Workman 2014) or, as discussed earlier, marketer-generated content (e.g., Thorson and Rodgers 2006) has used the term "eWOM,” making it more difficult to identify and progressively build on existing knowledge on this topic.

eWOM is not electronic recommendation systems. eWOM is a mechanism characterized by human social interaction and thus is quite different from electronic recommendation agents that "assist consumers in making product decisions by generating rankordered alternative lists based on consumer preferences” (Aksoy et al. 2006, p. 297). We acknowledge that eWOM may be "fed into" such recommendation systems via proprietary algorithms that may represent consumer opinions (Piramuthu et al. 2012); nonetheless, because the resulting recommendation may be significantly altered by the marketer and based on additional business intelligence, we consider this information marketer-generated and thus distinct from eWOM. 
eWOM is not online search rankings. We further distinguish eWOM from online activities that yield no recorded content. For example, Karniouchina (2011, p. 63) defines buzza common alias for eWOM—as “consumer excitement, interest, and communication around a [movie] project or a participating star that is capable of increasing their visibility with both moviegoers and movie industry participants.” This "buzz,” however, is measured by the intensity of Internet searches rather than actual consumer-generated content. In other words, it does not convey consumer opinions but rather levels of public awareness and/or interest. In that respect, these rankings resemble marketer-facilitated observational learning, in which others’ search behavior becomes visible to the public in aggregate form.

eWOM is more than observational learning. Prior research has clearly distinguished between WOM and observational learning (Chen et al. 2011b; Godes and Silva 2012; Libai et al. 2010; Ludwig et al. 2013). Compared with eWOM, which often reveals consumers' motivations behind an opinion or a recommendation, observational learning contains less information-it reveals the actions of other consumers, but not the reasons behind them (Bikhchandani et al. 1998). Online, observational learning assumes marketer facilitation. Consider, for example, the electronic recommendation systems employed by online retailers, which use algorithms to aggregate and report consumer behavior (e.g., “people who bought X also bought Y”). Increasingly popular are the so-called social contexts—online advertisements linked to snippets of text that show which friends have "liked" a page, event, or application (Li et al. 2014). Pauwels et al. (2016, p. 640) state that "eWOM includes observing the actions of peers ... [as this is part of] informal communications directed at other consumers about the ownership, usage, or characteristics of particular goods and services or their sellers.” Other scholars (e.g., Risselada et al. 2018) theorize observational learning as an underlying mechanism for eWOM, in which 
certain metrics (e.g., eWOM volume) signal the actions of others (e.g., eWOM volume implies the number of products sold) and therefore can be used for judgment. In summary, while some studies include observational learning in their scope of (e)WOM investigations (e.g., Pauwels et al. 2016), eWOM and observational learning are conceptually different—consumers' online actions may become visible through no action of their own but from the explicit effort on the side of the marketer. Therefore, we propose that eWOM is a broader phenomenon that has traditionally included explicit recommendations and mere mentions of products and brands and has expanded to non-textual mentions, implicit recommendations, and other online consumer actions (e.g., products featured in YouTube tutorials).

\section{Revised definition of eWOM}

As outlined, eWOM is conceptually distinct from other related online phenomena, and it is differentially shaped by consumers' circumstances and technological affordances. Furthermore, in light of the dynamic changes in the marketplace and the digital context, the prevailing views on eWOM have become outdated. For example, the most frequently used eWOM definition to date has the word "statement" at its core (see Table 1), which evokes mainly textual postings while ignoring other available formats. Similarly, eWOM may be directed to non-consumer audiences, such as company customer service representatives on specialized Twitter accounts, and still be visible to other consumers, due to the open nature of many platforms. Consequently, we recognize the need to revise the definition to reflect these and future changes. Thus, to facilitate consistent use of the eWOM construct and progressive knowledge building on this topic, we offer the following revised definition: eWOM is consumer-generated, consumptionrelated communication that employs digital tools and is directed primarily to other consumers. ${ }^{1}$

\footnotetext{
${ }^{1}$ We thank one of our anonymous reviewers for valuable feedback regarding this revised definition.
} 
This proposed definition of eWOM parsimoniously addresses the prevailing confusion about this concept. In addition, it allows us to delineate the key components for theory development: the source (i.e., consumers as senders of eWOM), the message (i.e., consumptionrelated content), the channel (i.e., digital conversation tools), and the receiver (i.e., primarily other consumers), in line with the source-message-channel-audience model of communication (Berlo 1960). For purposes of theory development, these elements continue to be "the key components [that] still represent a valuable starting point” (Yadav and Pavlou 2014, p. 32). To complete the discussion of the eWOM concept, we next address its theoretical foundations.

\section{Theoretical underpinnings of eWOM}

To date, many researchers have referred to the WOM theory to explain eWOM (e.g., Abrantes et al. 2013; Steffes and Burgee 2009). Less clear, however, is what such an overarching theory entails. Typically, three classic, enduring frameworks are evoked as (e)WOM theory: (1) Katz and Lazarsfeld's (1955) two-step flow theory, according to which information trickles down from mass media to opinion leaders and then to the general public; (2) Dichter's (1966) theory of involvement and motivations to engage in (e)WOM; and (3) Brown and Reingen's (1987) theory of strong and homophilous ties among (e)WOM participants. Common among all these early theories is their focus on influential consumers and their role in spreading information.

With the evolution of eWOM, other scholars have departed from this influence model. For example, Kozinets et al. (2010) critique the one-to-one interpersonal WOM theory and propose a revised, many-to-many network model made available by web-based technologies. Von Wangenheim (2005, p. 68) posits that there is "no single or consistent WOM theory that explains why and when [e]WOM is given [but rather that there are several] ... theories.” Relatedly, in their summary of early eWOM research, Cheung and Thadani (2012) distinguish 
between 13 theoretical approaches to eWOM; however, some of these approaches represent literature streams rather than particular theories (e.g., impression formation literature, trust literature, negativity bias). In line with these authors, we acknowledge a multiplicity of theories in extant eWOM scholarship. Over time, a range of economics, communication, information systems, psychological, and sociological theories have been invoked to explain the eWOM process. In particular, the number of psychological theories may seem overwhelming and lead us to conclude that the majority of knowledge on eWOM pertains to individual-level, underlying psychological processes; however, we find that as many as 767 studies (73\% of our sample) use field data (including surveys, quasi-experiments, and real-market data) to investigate eWOM and 239 of them (23\%) use lab data. ${ }^{2}$ Thus, a large part of extant eWOM research has drawn from real-life phenomena (for an overview of key theories and methodologies used per stage of the eWOM process, see Web Appendix 5). In the remainder of this article, we develop an organizing framework in which we describe how eWOM informs consumer decision making and how marketers can use it to support and influence consumer decision making.

\section{Organizing framework: The eWOM process}

Our central research focus is on identifying the enduring principles of eWOM (i.e., organize insights from extant research and trends related to eWOM) and highlighting outstanding debates and research avenues. Our organizing framework builds on the established MOA framework.

\section{Consumer MOA}

To organize extant eWOM research, we draw on the MOA framework and its underlying theory, which implies that the degree to which people process information is based on three factors: motivation, opportunity, and ability (MacInnis et al. 1991). Early work understood motivation as

\footnotetext{
${ }^{2}$ Some studies use both field and lab data. The sum is not $100 \%$ because the remaining studies use a purely conceptual, meta-analytic, or simulated analytical approach.
} 
"goal-directed arousal [or] ... the desire or readiness to process ... information” (MacInnis et al. 1991, p. 34); opportunity as "the extent to which distractions or limited exposure time affect consumers' attention to ... information” (MacInnis et al. 1991, p. 34); and ability as "the extent to which consumers have the necessary resources (e.g., knowledge, intelligence, money) to make an outcome happen” (Peters et al. 2013, p. 286). In the eWOM domain, research has used the MOA framework to explore how eWOM senders participate in discussion forums or in social media (e.g., Ashley and Tuten 2015; Lee et al. 2008), as well as how eWOM receivers process eWOM (e.g., Park et al. 2007; Tang et al. 2014). We extend these efforts and use MOA as a theoretical lens to synthesize extant literature from both consumers' (i.e., eWOM senders and receivers) and marketers' perspectives. In doing so, we map the research findings and gaps in this domain onto the three stages in the eWOM process: creation, exposure, and evaluation.

\section{Three-stage eWOM process}

As illustrated in Fig. 1, we conceptualize a three-stage process of eWOM that captures distinct consumer needs and behaviors, and we parallel marketers' needs and actions with respect to this phenomenon. This process is inspired by new conceptualizations of the consumer journey (e.g., Hamilton and Price 2019; Lemon and Verhoef 2016). For example, a common path is for consumers first to be exposed to eWOM before purchase and then to create eWOM after purchase; however, technological affordances now allow different paths. Thus, we propose that

this process is non-linear, as consumers may create eWOM in the form of pre-purchase buzz but never proceed to the eWOM exposure or evaluation stages for the same product category, and recursive (i.e., repeating on an individual level), in which consumers may re-experience the first stage (eWOM creation) as part of the decision process for another product. Throughout this process, consumers shift roles from (potential) eWOM receivers to (potential) eWOM senders, 
and vice versa. Moreover, they may skip stages, compress them, or extend them. This reality, however, does not negate the usefulness of conceptualizing the eWOM process as consisting of different stages that have a distinct nature and different goals and influences. For simplicity, we begin with a description of the eWOM process from the creation stage, as this stage is necessary for the subsequent stages of exposure and evaluation. Tables 2-4 summarize the key insights for the three stages.

--- Insert Figure 1 and Tables 2-4 about here ---

\section{Stage 1: eWOM creation}

eWOM creation includes consumer contributions of original content—either in a short-term fashion through one-time product reviews or through long-term engagement such as prolonged participation in online communities—and sharing other consumers' or companies' content such as re-tweeting (Gong et al. 2017). In turn, the marketer can support this creation by encouraging eWOM participation and designing benefits for the consumer (eWOM sender).

eWOM creation from a consumer perspective. In the past two decades, scholars have devoted significant attention to understanding consumers' motivations to create eWOM. The primary motivations identified in the literature are altruism toward other consumers or the company (Hennig-Thurau et al. 2004); social value from community interaction (Kozinets 1999; Peters et al. 2013); hedonic benefits, such as personal enjoyment and gratification (Kozinets 2016; McGraw et al. 2015; Motyka et al. 2018); impression management and identity formation (Belk 2013; Berger 2014; Moe and Schweidel 2012); balance restoration, venting, and retribution (Anderson and Simester 2014; Hennig-Thurau et al. 2004); and economic incentives (Ahrens et al. 2013; Godes and Mayzlin 2009). Researchers have also identified product characteristics that may prompt eWOM creation; for example, hyper-differentiated and niche 
products (e.g., craft beer [Clemons et al. 2006], limited-edition sneakers [Berger 2014]) may attract eWOM senders because impression management encourages consumers to talk about high-status, distinctive products and experiences. Overall, these motivations differently influence consumers' propensity to create eWOM and their specific eWOM content (e.g., negative opinions to signal expertise; Schlosser 2005). However, over time, eWOM senders’ motivations have changed owing to technological and social developments.

Three classic works illustrate these changes and the debate on the primary motivation to create eWOM: Kozinets (1999), Hennig-Thurau et al. (2004), and Berger (2014). In the early 1980s, consumers gathered in online communities of consumption in the form of email lists, Usenet newsgroups, bulletin board systems, and chat rooms (Okleshen and Grossbart 1998). Kozinets (1999, p. 254) highlights the prevalence of eWOM in these communities by defining them as "affiliative groups whose online interactions are based upon shared enthusiasm for, and knowledge of, a specific consumption activity or related group of activities.” Online communities, which attract consumers because of their mix of "social" and "topical” (i.e., product-related) benefits, are the cradle of eWOM. In the early 2000s, eWOM creation expanded with the introduction of dedicated online opinion platforms. Hennig-Thurau et al. (2004) developed a motivation-based segmentation of eWOM creators on these platforms that distinguishes among (1) self-interested helpers driven by economic incentives, (2) consumer advocates who act out of concern for other consumers, (3) altruists who want to help other consumers and companies, and (4) multiple-motive consumers. A decade later, Berger (2014) challenged the rationale that consumers can hold truly altruistic motives to create eWOM and posited that they engage in this behavior primarily out of self-interest (e.g., impression management, status). Berger's (2014) assessment is in line with academic discourse that 
identifies an evolution of online communication and consumer culture brought about by changes in the platforms and devices that consumers use to connect. Thus, while consumers' motivations are still multiple, as they are shaped by the platforms and communities in which they occur, they may be less social and altruistic than they were in the early days of the Internet.

In addition to motivation, consumers' creation of eWOM depends on their opportunity to access the Internet (e.g., device, connectivity; Mariani et al. 2019) and a platform on which to post eWOM. Greatly expanding this opportunity was the introduction of 3G, 4G, and 5G networks; widespread Wi-Fi; lower connectivity costs; and the global adoption of smartphones. As a consequence, eWOM has become more instantaneous (Berger 2014), and consumers can more immediately create eWOM throughout their decision-making journey (Liu et al. 2013). For example, they can check into a store and announce their intent to purchase, they can rate the service provider while enjoying a meal in a restaurant, and they can post a video of unpacking a product. However, consumers’ opportunities to create eWOM are often restricted (e.g., connection availability; Gruen et al. 2006). In this direction, research has examined the role of posting costs (e.g., eWOM senders may need to purchase the product or register as a member to post a review; Yadav et al. 2013). Another important technological development extending consumers' opportunity to create eWOM is the proliferation of eWOM formats (Berger 2014): text, ratings, images, videos, “Likes,” tags, and audios. Each format differentially affects eWOM effectiveness and its persuasiveness (Schweidel and Moe 2014).

Finally, eWOM creation is shaped by consumers' ability to access necessary resources (knowledge, expertise, skill) to create eWOM. To engage in eWOM communication, consumers must be familiar with the product (Lovett et al. 2013). Whereas the ability to create offline WOM may not have varied much among consumers, the increasingly complex technological 
environment causes considerable differences in consumers' abilities to create eWOM (Gruen et al. 2006). For example, more skill is required to create a video and post it on social media than to click on a star rating (Eisingerich et al. 2015). Despite the clear implications of consumers' abilities to create eWOM, this area remains under-theorized.

eWOM creation from a marketer perspective. Marketers have long attempted to stimulate eWOM—more of it, specific kinds of it, specific timing of it, or directed at a specific audience - by leveraging consumer motivations to create it through communication, incentives, and community building. Specifically, marketers often use short-term prompts or nudges (e.g., post-purchase Q\&A, requests to share top-of-mind brand experiences; Eelen et al. 2017). For example, Amazon.com, eBay, Sephora, and TripAdvisor have all introduced a consumer “questions and answers” feature (Hamilton et al. 2017; Kozinets 2016). By inviting verified purchasers to answer other consumers' questions about a product, these companies are appealing to altruism (Schulze et al. 2014). This information may prevent product returns by reducing uncertainty for other consumers; research has shown that products with more answered questions are indeed less likely to be returned (Minnema et al. 2016). Marketers have leveraged other consumer motivations to create eWOM, such as social value from interaction, by engaging with consumers in firm-owned or third-party communities. In these communities, eWOM creation can be stimulated, for example, through product co-development challenges (Beckers et al. 2018) or user testimonies, such as Harley Owners Group’s riding stories. Marketers sometimes resort to subtler approaches centered on self-presentation (Berger 2014). Consider, for example, firm investments in designing picture-perfect settings such as the Paul Smith pink wall in Los Angeles (Bean et al. 2018). These investments leverage consumers' interest in creating eWOM (e.g., the perfect pink wall pictures on Instagram) and are tied to their self-interested impression 
management motivations. Extant research in this area indicates that providing social status markers on a platform, such as reviewer badges (e.g., Baek et al. 2012) and helpfulness scores (e.g., Hong et al. 2017), motivates consumers to create eWOM to increase their status, which may even shape the valence of their opinions (e.g., make them less extreme; Schuckert et al. 2015).

In addition to these firm-to-consumer communication efforts to stimulate eWOM, marketers can offer incentives to eWOM senders, which may include economic rewards (Du Plessis et al. 2014). For example, the cosmetics brand Jane Iredale offers loyalty points when registered members post online reviews on the brand's platform. Marketing research documents reasons marketers should (and should not) incentivize eWOM creation. First, offering economic benefits is more effective than offering none or offering only social benefits (Ahrens et al. 2013; Dose et al. 2019). Yet caution is warranted: extrinsic rewards may weaken the relationship between loyal consumers and the brand (Godes and Mayzlin 2009), as well as decrease their referral behavior (Dose et al. 2019). Second, research also documents that monetary rewards motivate passive members (Garnefeld et al. 2012) and those with few social connections (Sun et al. 2017) but demotivate active and well-connected members (for whom normative incentives and status markers may be more effective; Garnefeld et al. 2012). Finally, a caveat regarding extrinsic rewards lies in the resulting valence of eWOM and a long-term change in senders' attitudes_-incentives may increase negative eWOM (Poch and Martin 2015) and bias senders’ attitudes toward the product (Kim et al. 2016).

The marketer’s role in eWOM creation has been further complicated by regulatory changes. Incentivizing eWOM may have gone undisclosed for a long time-making the incentives a purer individual benefit driver-but today eWOM senders are often legally 
obligated to disclose any benefits (see, e.g., Federal Trade Commission’s [2017] “Endorsement Guidelines”). Through such disclosures, eWOM senders’ benefits become visible to others and may acquire social status (e.g., "She has a professional connection to Louis Vuitton”), thereby creating positive externalities, such as increased credibility and subsequent eWOM, that may affect future consumers' attitudes and purchasing behaviors (Carr and Hayes 2014). By contrast, such disclosures may discredit eWOM senders in the eyes of their audiences (e.g., "She is selling out to Louis Vuitton”; Ashley and Leonard 2009; Kozinets et al. 2010) and lower eWOM receivers’ product quality expectations (Du Plessis et al. 2014).

In addition to triggering consumers' motivation to create eWOM, marketers at times get involved in eWOM creation by demotivating consumers from eWOM creation (e.g., by inviting negative feedback to be sent directly to the firm, instead of being shared publicly). Some firms are actively trying to combat this marketer practice; for example, Amazon.com provides guidelines that help regulate buyer-seller messaging (i.e., discourage sellers from diverting buyers' dissatisfaction from public to private channels or from requesting that the consumer alter an unfavorable review following webcare interventions). While such guidelines prohibit deceptive eWOM conduct, some marketer efforts to encourage eWOM creation remain unethical and, at times, unlawful. Scholars have assessed the impact of incentivizing fake positive reviews (Mayzlin et al. 2014) and "injecting” competitors with negative eWOM (Lappas et al. 2016). Broadly, marketers' manipulations decrease eWOM usefulness and value (Mayzlin et al. 2014). Marketers' involvement with eWOM creation actually begins by securing the necessary opportunities for consumers' contributions, such as designing a web page on which consumers can leave textual reviews. eWOM creation is further shaped by technological and platform affordances, which marketers can control. On some platforms, consumers have the opportunity 
to access a platform (e.g., no barriers to enter; Gruner et al. 2014), reach and form ties with others (e.g., Stephen and Lehmann 2016), and create eWOM (e.g., posting a review following a verified purchase on Expedia.com vs. posting unrestrictedly on TripAdvisor.com; Mayzlin et al. 2014). At times, platforms try to minimize the manipulation of eWOM creation to ensure highquality information (e.g., GameSpot allows only one review per consumer per game; Zhu and Zhang 2010). Another important factor is consumers’ opportunities to self-present via status markers (e.g., VIP badge; Hanson et al. 2019), and this may support eWOM creation.

Marketers can also benefit from building online communities. Schau et al. (2009) describe community practices that marketers can support to increase value co-creation. Many of these practices directly relate to eWOM; consider milestoning, for example, which is the practice of noting landmark events in brand ownership and consumption, such as Saab drivers relaying tales of their cars’ odometers hitting 100,000 miles (Schau et al. 2009, p. 44). Marketers can also support community members in their evolution from mere lurkers to active contributors, thus increasing the pool of members who create eWOM (De Valck et al. 2009; Kozinets 1999).

Marketers can further shape eWOM creation by prescribing the eWOM format, such as the length of text (e.g., 140-280 characters on Twitter, six-second videos on Vine; Schweidel and Moe 2014), and other features, such as the color and size of online rating scales (Jiang and Guo 2015) or the "Like” button, which allows users to show support for specific online content (e.g., comments, images). Research indicates that these opportunities influence eWOM creation and that consumers respond differently to the varying elements of communication. For example, in their study on online product reviews, Chen and Godes (2012) show that consumers report higher eWOM creation intentions when rating on a 5- versus a 100-point scale, presumably because of "rating certainty" (i.e., the extent to which an online context allows consumers to rate 
in a way that accurately captures their underlying utility). Smith et al. (2012) demonstrate that the volume, valence, and content of eWOM — even for the same brand — can all differ across platforms because of consumers’ varying opportunities for expression (e.g., brands are more central in eWOM on Twitter than on YouTube or Facebook). Furthermore, the mere number of opportunities to create eWOM may change (i.e., bias) the eWOM sender's attitude (Kim et al. 2016). Many marketers have experimented with these elements to influence eWOM creation (e.g., Facebook’s multiple changes to its ratings format since 2011).

Finally, in addition to leveraging motivations and opportunities, marketers can support eWOM creation by increasing consumers' abilities—skills, proficiencies, and competencies to engage in eWOM exchange with other consumers (Gruen et al. 2006)—-thereby helping them mitigate the risks associated with using certain platforms (Eisingerich et al. 2015). Without the necessary cognitive resources, even a motivated consumer will not create eWOM (Gruen et al. 2006). Marketers may assist consumers with the complex aspects of eWOM creation; for example, Sephora provides detailed guidelines for rating and reviewing products to educate consumers on how to compose and submit eWOM.

\section{Research gaps for eWOM creation.}

The first goal of this article was to provide a multidisciplinary overview of extant knowledge on eWOM. To complement knowledge development efforts in this area, we provide a research agenda for each stage in the eWOM process, which we hope will stimulate future research. Here, we first discuss the research gaps identified for eWOM creation.

1. Settle debates on incentivizing eWOM creation. As discussed previously, debate is ongoing about the benefits and optimal structure of eWOM incentive programs. This debate raises questions such as whom to incentivize (loyal consumers vs. others), how to incentivize 
them (with economic or non-economic benefits), and whether and how to disclose the incentive to others. In addition, how do incentives and rewards affect $e W O M$ senders (e.g., motivation to post, brand perceptions, consumer engagement, loyalty) and the nature of eWOM (positive or negative)? A promising avenue for future research lies in the overlap of eWOM and consumer loyalty program design, as marketers increasingly offer loyalty points to spark eWOM creation. Recently, Breugelmans et al. (2015) called for research on the cost and reward structure of loyalty programs because it is unclear how redemption of loyalty points affects consumers and firms. We argue that, in light of incentivization-related debates in the eWOM literature, the question of redemption would be especially relevant when consumers receive points to create eWOM. For example, Jane Iredale rewards consumers with 20 points for each written online review. It is plausible that loyalty point redemption may negatively affect consumer engagement, brand attitudes, and firm profitability.

2. Explore eWOM senders' abilities. Prior research shows that differential levels of consumer ability influence eWOM (Gruen et al. 2006). However, it is not clear specifically how eWOM senders' ability influences eWOM creation and how that, in turn, shapes the subsequent stages of the eWOM process (i.e., on eWOM receivers’ side). For example, Internet proficiency and past experience with eWOM may help shape consumers’ eWOM contributions (in terms of information formats, metrics, and so on). On the marketer side, how effective are practices to structure eWOM, as well as to educate and guide consumers through eWOM creation? How does this affect eWOM content and eWOM valence? For example, if consumer abilities are high and perceived level of difficulty to create eWOM is low, will eWOM be more balanced as a result? If perceived as difficult, will consumers engage in more extreme eWOM? In which case is eWOM more persuasive? 
3. Explore eWOM and privacy issues for unsought products. What are the consequences of the identified trends in eWOM creation? If consumers indeed hold more self-oriented motivations, will they ever be interested in sending eWOM about products that have less identity-signaling value or that threaten identity preservation? Will there be an unbalanced representation of the types of products referenced by eWOM? Extant research has not yet captured the contexts of unsought products. For example, an Amazon.com product page for a \#1 best-selling hemorrhoid cream shows merely 183 reviews (despite more than 10 million annual cases in the United States, according to the Mayo Clinic ${ }^{3}$ ). By contrast, best-sellers in other Health \& Personal Care categories receive significantly more eWOM (e.g., more than 3,400 reviews for top brands of allergy medicine). Consequently, it is important to explore how to motivate consumers to create eWOM for unsought products and increase public selfconsciousness (Townsend et al. 2019).

\section{Explore the helpfulness of altruistic eWOM creation. Because the market for eWOM} has professionalized with the rise of pay-per-post arrangements, influencer marketing, and other marketer-driven tactics geared toward boosting the creation of eWOM, the weight of altruistic eWOM has declined in favor of incentivized eWOM providing individual-oriented benefits, such as recognitions through badges. At the same time, research on the effectiveness of altruistic eWOM creation encouraged by the marketer is lacking. For example, how helpful is eWOM that results from a firm’s invitation to participate in Q\&A about a purchased product? Anecdotal evidence suggests that altruistic eWOM creation is not always helpful or useful, as consumers sometimes reply to a question by stating "I do not know about this feature."

\footnotetext{
${ }^{3}$ Mayo Clinic. (2016, May 13). Retrieved May 20, 2019, from https://www.mayoclinic.org/medicalprofessionals/digestive-diseases/news/hemorrhoidal-disease-diagnosis-and-management/mac20430067\#targetText=Diagnosis,so\%20they\%20suffer\%20in\%20silence.
} 
5. Investigate the types of online communities in which eWOM creation is most valuable for both consumers and marketers. Generating and maintaining engagement in online communities is critical for marketers to enhance relationships and gain customer loyalty (Hanson et al. 2019; Kozinets 1999). Marketers can invest in a firm-owned brand community or collaborate with third-party or consumer-initiated communities. However, online communities vary in ownership and governance structure (Sibai et al. 2015), platform characteristics and affordances (Dholakia et al. 2004), community culture (Kozinets et al. 2010), and purpose (e.g., fan vs. activist communities; Kozinets and Handelman 2004). Although much is known about consumer participation in online communities and its effect on consumer decision making (e.g., Adjei et al. 2010; Relling et al. 2016; Wiertz and De Ruyter 2007), little is known about how eWOM creation differs (e.g., in volume) across these different types of communities. A better understanding of how community governance, affordances, and culture influence eWOM creation will help marketers make strategically informed decisions about which communities to target. For example, when is it appropriate to support a brand public versus a brand community? How should marketers deal with negative eWOM in consumer activist communities?

\section{Stage 2: eWOM exposure}

After eWOM is created (by eWOM senders), other consumers (eWOM receivers) take note of it. This awareness may be the result of either an active search or consumers' accidental exposure, and it may be supported by marketer actions. In this stage, marketers may try to facilitate this exposure by maintaining online platforms on which eWOM receivers can access eWOM, as well as through online tactics such as search engine optimization. Further understanding of "best practices in capturing exposures across platforms" is important, to enable a holistic view of the consumer (Marketing Science Institute 2018). 
eWOM exposure from a consumer perspective. What do we know about consumers' MOAs with regard to eWOM? In a recent survey, $63 \%$ of respondents reported that reading reviews before buying an unfamiliar product or selecting a new service provider is highly important (Worldpay 2017). In general, consumers' motivations to seek eWOM are shaped by individual traits (e.g., need for cognition [Gupta and Harris 2010], perceived expertise, market mavenism [Adjei et al. 2010]) and goals throughout their decision-making journey. One important goal is to reduce pre-purchase uncertainty and the perception of risk (Moe and Trusov 2011). Products with attributes that are difficult to observe, predict, verify, or control are associated with higher levels of risk (Lee and Bell 2013), which in turn may motivate consumers to seek eWOM. For example, consumers may search for eWOM when they perceive high functional risk (e.g., new products whose performance is unknown; Ho-Dac et al. 2013), high financial risk (e.g., long-term investments; Grewal et al. 2004), and/or high social risk (e.g., publicly consumed products; You et al. 2015). Finally, consumers seek eWOM after purchase to reduce cognitive dissonance (Bailey 2005) or to problem-solve (Mathwick et al. 2008).

Whereas these motivations for seeking eWOM are primarily utility-driven, recent research has also identified consumers search for eWOM as a leisure activity (Goldsmith and Horowitz 2006). This trend may be related to the proliferation of humorous eWOM (McGraw et al. 2015) and the prevalence of online influencers. Online influencers exert a greater-thanaverage social influence through eWOM (Kozinets et al. 2010; Kupfer et al. 2018), due to their large audience, authority, and/or trustworthiness (Algesheimer et al. 2005). Consumers are motivated to follow influencers—and are exposed to their eWOM—because they find their posts entertaining, interesting, and inspirational (Gong and Li 2017). The decision of an influencer to recommend a brand —and, thus, the probability of consumers to be exposed to eWOM—is a 
function of the influencer's social network (e.g., size) and recipient type (e.g., platform member vs. non-member). Notably, long-term influencers recommend brands less frequently than new influencers, but their recommendations have higher conversion rates (e.g., receivers are more likely to act on their recommendation to visit a website; Chatterjee 2011).

Consumers gain exposure to eWOM not only from their active search behavior related to purchasing but also from accidental exposure to eWOM (Hildebrand and Schlager 2019). This happens when consumers spend time on social media, watch online videos, or surf the Internet (Chen and Berger 2016). In effect, every time consumers create eWOM, they are exposing their first-circle connections to it (Lipsman et al. 2012). Given the penetration of certain platforms (e.g., 26\% of the world's population uses Facebook; Internet World Stats 2017), such accidental exposure to eWOM is significant (Moran et al. 2014). We also argue that such exposure has increased over time from FOMO (fear of missing out), as this makes consumers exceptionally attentive to messages from those in their social circle (Beyens et al. 2016).

Consumers' opportunity to be exposed to eWOM is determined by contextual factors, such as Internet penetration, available time, platform characteristics, and network-related factors. For example, when consumers participate in online communities of consumption, they are more likely to be exposed to eWOM because they linger at reservoirs of consumer knowledge (De Valck et al. 2009). In addition, prior research has shown that eWOM exchange is shaped by specific periods including holidays (Bruce et al. 2012) and days of the week because of Internet searching patterns (e.g., increased search on the weekend; Rutz and Bucklin 2011).

Furthermore, eWOM receivers may incur platform and/or eWOM access costs, such that they must overcome certain entry barriers or complete steps (e.g., registration) before they can gain access to eWOM (Gruen et al. 2006). By contrast, some platforms expose visitors to eWOM 
immediately on arrival (Schau et al. 2009). Considering access costs, we distinguish between restricted and open-access platforms (Gruner et al. 2014). A recent study finds that open-access and more "loosely knit" sharing environments, such as Twitter, are particularly effective for viral dissemination and may significantly increase exposure to eWOM (Hayes et al. 2016). Other platform affordances also allow consumers to access more eWOM than ever before: for example, a Google search for a restaurant returns average ratings from different sites (e.g., Facebook, Foursquare, OpenTable), thereby exposing consumers to unsolicited eWOM. This may be more common for products with high signaling value (e.g., high-end restaurants), as these types of products are typically featured on people's social accounts (Moran et al. 2014).

Building on the strength-of-weak-ties theory (Granovetter 1973), prior research also demonstrates that larger consumer networks (Peters et al. 2013), higher in-degree centrality of the consumer in those networks (Lu et al. 2013), and boundary-spanner positions with high betweenness centrality (Schulze et al. 2014) all increase the probability of exposure to eWOM. In addition, research on eWOM contagion and diffusion finds that more consumers get exposed to eWOM as a function of (1) the depth of influence (e.g., the number of social connections that an eWOM message jumped [Kumar et al. 2013], the proportion of the population reached by the message [Langley et al. 2014]), (2) the velocity or speed of contagion (Kumar et al. 2013), and (3) the uniformity of direction (i.e., the existence of a dominant opinion shared among eWOM senders; Langley et al. 2014).

Finally, we posit that consumers' exposure to eWOM is shaped by their abilities, which are driven by the particular consumption context and individual characteristics, such as age, literacy, language and Internet proficiency, and also the capabilities to join eWOM platforms and navigate different eWOM formats (e.g., online reviews, social media posts). Prior research finds 
that higher Internet proficiency lowers online search costs and subsequently increases consumers’ likelihood of using eWOM to expand product knowledge (Zhu and Zhang 2010).

eWOM exposure from a marketer perspective. In this section, we explore what is known about marketers’ role in consumers’ exposure to eWOM. For example, what can Amazon.com do to effectively facilitate consumers’ active search for or accidental exposure to eWOM? Primarily, the traditional marketing-mix elements such as product design and advertising (e.g., more complex, risky, and controversially advertised products) can motivate consumers to search for additional product information (Schmidt and Spreng 1996). In addition, marketers can more directly invite consumers to complement their internal knowledge and reduce uncertainty through eWOM (e.g., to follow a brand on Twitter [Rui et al. 2013], to check other shoppers’ opinions [Aldo 2017]).

Marketers can also increase consumers’ opportunities to be exposed to eWOM. For example, they can make eWOM more visible and more searchable. eWOM that is indexed and displayed by search engines and social media platforms holds large potential for worldwide exposure (Moran et al. 2014). Marketers may also feature eWOM in their owned media, such as in store (e.g., Hansen and Sia 2015), in promotional materials and newsletters, as well as through search engine advertising (e.g., star ratings displayed in Google ads). Similarly, when searching for brands or companies on Facebook, consumers can see average ratings and recommendations; they may also see when network members are seeking recommendations (e.g., on Facebook), effectively stumbling upon incidental eWOM. This accidental exposure to eWOM may happen more on social media and online community platforms, which are inherently designed to support social interaction rather than retailer services. 
In addition, marketers may help consumers' search for eWOM by building a sorting feature (e.g., by date) in the platform and by allowing customized eWOM search (e.g., checking a box to ensure similar skin type via Beauty Matches on Sephora.com). Some platforms also offer partial, on-demand displays of eWOM, such that users can search for specific content or sort eWOM by, for example, favorability (Ghose et al. 2014), recency (e.g., "sort by newest” on Travelocity.com), their own preferences (e.g., eye color on Sephora.com), or eWOM sender characteristics (e.g., family status on HolidayCheck.com; Brandes et al. 2011). Finally, to expose consumers to eWOM, marketers can reduce the signal-to-noise ratio on their platforms, that is, minimize the distracting "information [within eWOM] with little or no relevance to specific products and brands” (Tirunillai and Tellis 2012, p. 199).

As part of the strategy in this stage of the eWOM process, however, marketers may also want to restrict exposure to eWOM for strategic and brand preservation reasons. This primarily occurs through controlled displays of eWOM in owned media. Prior research documents many examples of this practice; on some platforms, eWOM is displayed only after a minimum volume threshold has been reached (e.g., four ratings per restaurant [Lu et al. 2013], 10 reviews per eWOM sender [Clemons et al. 2006]). In addition, marketers can control the exposure to eWOM by determining the amount of eWOM displayed per page (e.g., five reviews per page on Travelocity, 10 per page on TripAdvisor; Ghose et al. 2012). Overall, platform design may limit consumers' opportunities to be exposed to eWOM and may even result in eWOM bias (e.g., because some consumers only seek eWOM on the first page of a site; Ghose et al. 2012).

Finally, to expose consumers to eWOM, marketers can influence their ability. To this end, they can lower consumers' platform access costs and eWOM search costs and educate them on searching through large amounts of eWOM (e.g., how to use the hashtag to retrieve tweets on 
a topic or to sort reviews on a retailer platform). Consider the case of Amazon.com in 2003, when consumers needed to invest significant search efforts to find eWOM on a product page (Babić Rosario et al. 2016); today, eWOM is immediately visible. Ultimately, today’s consumers do not need to be particularly skilled to find eWOM on most platforms.

\section{Research gaps for eWOM exposure.}

In the eWOM literature, researchers have mainly considered how consumers search for eWOM. The following initial insights regarding eWOM exposure still need further exploration.

\section{Investigate maximizing versus satisficing eWOM search behaviors. Prior studies} confirm that eWOM is a risk-reducing mechanism (Lovett et al. 2013). However, what specific behaviors do consumers engage in to mitigate risk? For example, what are the effects of searching for eWOM on one versus multiple platforms, maximizing versus satisficing eWOM search behavior, or soliciting versus not soliciting eWOM to reduce risk? It is possible that consumers faced with many alternatives may engage in satisficing eWOM searches (You et al. 2015). While maximizing and satisficing strategies in online information seeking are widely available in the information systems literature, eWOM scholars have not yet investigated the socalled cognitive economy (Warwick et al. 2009). Relatedly, in light of emerging technologies, consumers are using augmented reality (e.g., viewing a couch in own room using a smartphone camera) and other sampling opportunities (e.g., "look inside” a book on Amazon.com). So, what will be the role of eWOM relative to this new risk reduction?

2. Investigate curated and altered eWOM. As discussed previously, extant research indicates that marketers' actions shape consumers' opportunities to be exposed to eWOM (e.g., by controlling its display online; Brandes et al. 2011). Scholarly attention in this area has focused on digital environments, even though the modern consumer engages in an omni-channel journey. 
Elements of digital communication are seeping into people’s analog lives, as marketers are including eWOM in their offline settings (Hansen and Sia 2015). Examples include the cardboard Instaframe cutouts used at social events and Amazon.com's recent opening of "4-star" stores, stocking four-star-and-above-rated products from various categories and featuring electronic price tags that show average star ratings updated several times a day (Goldberg 2018). Consumer behavior across offline and online environments has been the subject of several recent investigations. For example, Pauwels et al. (2011) show that consumers exposed to offline marketing further browse online for convenience, and vice versa. Kushwaha and Shankar (2013) demonstrate that consumers who shop for hedonic products across the two environments spend more money than those who use just one channel. De Haan et al. (2018) show that consumers who switch between channels (e.g., from a smartphone to a desktop computer) exhibit a higher conversion rate. Lacking in extant research, however, is knowledge about the effectiveness of cross-channel or omni-channel marketers' curated displays of eWOM. Specifically, academic attention has largely neglected marketers' use of eWOM for promotional purposes in owned media, such as quoting consumers' online reviews in official newsletters, instore product description labels, and mass promotion. This marketer practice is prevalent and interesting because it contains elements of — while remaining conceptually distinct from— testimonials and eWOM. On the one hand, it is possible that these hybrid forms of marketrelevant information will replace both advertising and eWOM. On the other hand, eWOM senders' original intentions and disassociation from commercial interest (Dichter 1966) may be questioned, potentially reducing the credibility of the message (see Thompson and Malaviya 2013) and activating consumers' persuasion knowledge. Further research could address the 
question: How does the embeddedness of eWOM in marketing messages alter its meaning and effectiveness?

3. Investigate optimal platform design in high-social-risk contexts. Perceived social risk tends to be higher for hedonic and high-status products because of their symbolic value for social groups (Miller et al. 1993). This necessitates reliance on reference groups and implies higher susceptibility to peer-generated information such as eWOM (Childers and Rao 1992). Thus, marketers need to ensure that eWOM is available when and where consumers need it. However, marketer actions may not be intuitive in this particular consumption context, as eWOM may signal messages incongruent with the brand. For example, a high volume of online reviews signals wide adoption of the product (Babić Rosario et al. 2016), which is counterintuitive to luxury marketing in which scarcity and unavailability are considered dominant appeals. While several studies have explored the role of eWOM for luxury hotels (e.g., Dinçer and Alrawadieh 2017), restaurants (Hoffman and Daugherty 2013), and fashion (e.g., Kim and Ko 2012), research in this area has been scant overall. Consequently, it is pertinent to explore ways to reduce uncertainty with eWOM while preserving the brand in contexts with high social risk.

4. Distinguish eWOM as a proxy from eWOM as a market influence. Future research should better distinguish between eWOM metrics that are visible to consumers (e.g., average rating) and econometrically derived metrics researchers and practitioners use to approximate underlying issues in the market (e.g., variance, "incremental” rating). More insight is necessary into the way consumers respond to eWOM that they have actually read, seen, or heard versus eWOM that was merely present on a platform but never seen (Cadario 2015). Thus, we call for research to employ eye-tracking methodology to advance understanding of consumers’ processing of eWOM. 


\section{Stage 3: eWOM evaluation}

Consumers (eWOM receivers) evaluate eWOM to inform their decisions. Marketers manage eWOM to ensure its relevance for consumers and perform webcare to preserve brand image.

eWOM evaluation from a consumer perspective. Motivation in this stage refers to consumer readiness, interest, desire, or willingness to process eWOM (Tang et al. 2014). Prior research suggests several motivational drivers among the characteristics of (1) eWOM receivers, (2) senders, (3) message characteristics, and (4) other contextual characteristics.

Primarily, the motivation to process information is shaped by eWOM receivers’ psychological characteristics, such as their susceptibility to interpersonal influence (Naylor et al. 2012), innate desire to think about information (i.e., need for cognition; Gupta and Harris 2010), and psychological need for uniqueness (Wang et al. 2012). For example, consumers scoring high on need for uniqueness tend to resist majority influence, which makes them less susceptible to certain eWOM signals such as the high volume of messages (Wang et al. 2012). Early studies on eWOM evaluation also highlight gender as an important factor, with men finding eWOM to be of higher quality than women (Awad and Ragowsky 2008). Cultural characteristics such as uncertainty avoidance, individualism, and power distance also help explain which consumers value peer information for reducing consumption risk (Kübler et al. 2018).

Furthermore, prior research notes a strong relationship between involvement and eWOM processing: as involvement increases, consumers are more motivated to comprehend salient information (Lee et al. 2008). Otherwise, as involvement to process eWOM decreases, consumers want to reduce pre-purchase evaluation efforts (King et al. 2014) and tend to use other people’s opinions as a decision heuristic (Risselada et al. 2018). For example, consumers are presumably more involved when they are members of an online community of consumption 
and when they actively search for eWOM (vs. being exposed to it accidentally); here, their motivation to evaluate eWOM is generally already high, and they are likely to engage in more effortful information processing (Lu et al. 2013). However, when involvement is low, consumers rely on peripheral cues such as sender credibility, expertise, trustworthiness, and personal similarity (Lee et al. 2008). In general, eWOM from credible senders is more valuable and more influential (Mayzlin 2006). Similarly, a credible eWOM message—one that is similar to the eWOM receiver’s own product evaluation (Zhao et al. 2013), complete and detailed (Jiménez and Mendoza 2013), objective (Kusumasondjaja et al. 2012), or rated as helpful (Ghose and Ipeirotis 2011) — exerts more influence on consumer behavior (Jiménez and Mendoza 2013).

Research highlights other message characteristics that affect consumers' motivation to evaluate eWOM. Overall, consumers prefer simple eWOM information to complicated content (Dillard et al. 2007) and more neutral to valenced eWOM (Tang et al. 2014). Yet an important finding in the literature is that not all neutral messages are created equal. Neutral eWOM, which contains mixed information (with both positive and negative valence), can stimulate consumers' curiosity to evaluate additional eWOM (Tang et al. 2014). However, when neutral eWOM lacks both positive and negative assessments, consumers' motivation to further evaluate eWOM decreases, as they consider indifferent messages less interesting (Tang et al. 2014).

With regard to consumers' opportunities to evaluate eWOM, research is in disagreement. Gruen et al. (2006) find that eWOM receivers' opportunity does not influence their perceived value of eWOM (while motivation and ability do). However, subsequent studies demonstrate that consumers may evaluate eWOM differently depending on the opportunity provided, in terms of devices, format, length, or order of presentation. For example, receivers may absorb emotion that is expressed in textual eWOM (e.g., anger; Fox et al. 2018) and perceive longer eWOM 
messages as more accurate and informative (Risselada et al. 2018); at the same time, they may perceive longer eWOM messages as more complex and requiring additional cognitive resources (Ghose and Ipeirotis 2011).

Consumers’ abilities to evaluate eWOM refer to their cognitive resources, skills, or “proficiency in interpreting information given prior knowledge” (Peters et al. 2013, p. 286). If consumers' abilities to evaluate eWOM are inadequate, the resulting processing of information will be superficial and/or partial (Mafael et al. 2016), leading to impoverished persuasion and attenuated bottom-line effects (Kuo and Nakhata 2019; Tang et al. 2014). Research also finds that as eWOM proliferates, consumers filter information on the basis of certain characteristics, as they are not able to evaluate all of it at once (De Langhe et al. 2016; Risselada et al. 2018). For example, sorting reviews by helpfulness may simplify consumers’ evaluation. By contrast, consumers may adopt a more advanced cognitive elaboration of eWOM (Kozinets 2016; Simonson 2016); in particular, experienced eWOM receivers have learned to integrate disparate product claims and to infer unstated product attributes (Tang et al. 2014). Similarly, consumers often adopt a systematic processing strategy when eWOM is complex (e.g., it contains both positive and negative information; Tang et al. 2014).

eWOM evaluation from a marketer perspective. How can marketers leverage consumers’ MOA to evaluate eWOM? Furthermore, how can they evaluate and moderate eWOM on their end to ensure the preservation of their brand image? Scholars have been debating whether marketers can truly influence consumers' motivations and abilities to evaluate eWOM. Research in this area is limited, but some studies show that providing monetary compensation to increase eWOM receivers' involvement results in differing eWOM evaluations and increased usage of central cues, such that the message is more heavily elaborated by the 
consumers (Ahrens et al. 2013). Risselada et al. (2018) find that structured eWOM (e.g., highlighting pros and cons of a product or displaying a bulleted list) is easier to comprehend and ultimately evaluated as more helpful than unstructured eWOM. On some platforms, marketers use color to guide consumers and increase their ability to spot outdated content (e.g., older eWOM is brighter; Brandes et al. 2011).

Importantly, by shaping the technological affordances of the platforms, marketers provide consumers with opportunities to evaluate eWOM. For example, they may include information known to affect credibility assessments (e.g., status markers such as “top reviewer” badges, social cues such as helpfulness votes; Baek et al. 2012), determine the format of eWOM, and make managerial responses observable or not (Wang and Chaudhry 2018); these activities can substantively influence consumer perceptions and purchase intentions (Babić Rosario et al. 2016). In their study on online reviews, Xu et al. (2015) demonstrate that text, image, and video formats differ in perceived credibility and persuasiveness, ultimately resulting in differential intentions to purchase the product. Other marketer-afforded opportunities to evaluate eWOM include supporting eWOM creation by adding a spelling checker and specifying the length of a review (i.e., the maximum number of words); in supplying these features, marketers do not affect actual eWOM content but influence how consumers process the information.

In addition to leveraging consumers' MOA to shape their eWOM evaluation, marketers need to evaluate eWOM for themselves. We identify three key guidelines on the basis of extant research. First, marketers should track eWOM across different platforms because their inherent characteristics have implications for the nature and scope of the eWOM exchange. Research has shown that "listening in" on just one (type of) platform may lead to erroneous estimations of the scope and consequences of eWOM because platforms "are different and can show varied 
patterns of [e]WOM" (Lovett et al. 2013, p. 442). However, "little attention has been given to [platform] differences, [which] is particularly troubling” (Schweidel and Moe 2014, p. 388). Second, when listening in, marketers should understand and use advanced methodological approaches developed to collect eWOM and information about its senders and receivers. One of the most acclaimed methods in this area is netnography (Kozinets 2002). In addition, it is important to account for the dynamic and endogenous nature ${ }^{4}$ of eWOM. In comparing methodologies, several recent studies (e.g., Babić Rosario et al. 2016) have found that relying on simpler regression techniques instead of statistically more robust methods may lead to serious overestimations of eWOM effectiveness. Marketers should also be sensitive to the time necessary for eWOM to yield measurable marketplace effects. For example, Tirunillai and Tellis (2012) observe that eWOM might take from a few days to weeks to be fully reflected in business performance. Other methodologies, adapted for eWOM processing and analysis, include natural language processing, sentiment analysis, stylometric analysis, and advanced text classification (e.g., Lee and Bradlow 2011). Third, following their own evaluation of eWOM, marketers can (and should) engage in webcare (e.g., by directly responding to eWOM senders). Recent research suggests that such communication should be personalized (Schamari and Schaefers 2015), moderately frequent (Homburg et al. 2015), and observable to subsequent eWOM senders (Wang and Chaudhry 2018).

\section{Research gaps for eWOM evaluation.}

We see much room for additional research on eWOM evaluation. There is a strong need to examine the robustness of consumer MOA in an increasingly complex digital environment.

\footnotetext{
${ }^{4}$ The endogenous nature of eWOM signifies that eWOM is not only a driver of firm performance (e.g., sales measures), but it could also be its outcome (e.g., high-selling products attract more eWOM) (Chintagunta et al. 2010).
} 
1. Explore the role of devices used to evaluate eWOM. A fruitful area for further research is the role of the device consumers use to access the platform and evaluate eWOM, such as desktop computers, touch-based devices (e.g., smartphones), or touchless devices (e.g., wearables, Microsoft Kinect) (Yadav and Pavlou 2014). We know that consumers tend to selfidentify with mobile devices (Liu et al. 2013), and these devices can act as influential agents that deliver eWOM and meet consumers' expectations of staying connected, informed, and entertained (De Haan et al. 2018). These factors may, consequently, influence the way consumers evaluate eWOM. Academic research finds that certain devices differently affect the other two stages of the eWOM process (i.e., eWOM creation and exposure) (Mariani et al. 2019; Melumad et al. 2019; Xu et al. 2015). Some managerial studies find that consumers prefer to research products on personal computers over smartphones (Shannon-Missal 2013), suggesting that devices may differentially affect eWOM evaluation as well. However, to the best of our knowledge, marketing scholars have not fully explored this notion (notable exceptions include recent studies by Grewal and Stephen [2019] and März et al. [2017]).

\section{Explore the consequences of facilitated eWOM creation on eWOM evaluation. As}

discussed previously, marketers aim to facilitate consumer engagement by making eWOM more searchable. For example, they create hashtags to allow consumers to more easily locate mentions of products. Such social tagging systems have become prevalent; "images are tagged and shared on Pinterest and Facebook, videos are tagged on YouTube, and Tweets are tagged (using hashtags) on Twitter” (Nam and Kannan 2014, p. 21). Yet, while hashtags can increase eWOM exposure, it is unknown how they affect evaluation and downstream consequences. Because eWOM senders can (ab)use hashtags, eWOM receivers plausibly find multiple perspectives but not a guaranteed, true sense of community (Arvidsson and Caliandro 2016). Consider the failure 
of McDonald's \#McDStories Twitter campaign, which resulted in an online firestorm (Pfeffer et al. 2014). While prior research offers a marketer perspective on the value of tagging systems (Nam and Kannan 2014), little is known about how consumers evaluate such eWOM and how it influences their engagement and choice.

3. Explore the role of other eWOM formats (e.g., visual). It is time to consider formats other than text and numerical ratings, as well as new, rapidly growing visual platforms such as YouTube, Instagram, Pinterest, and Snapchat. We echo recent calls for additional research on visual eWOM (e.g., King et al. 2014) and urge marketing researchers to develop robust methodologies for in-depth analysis of visual content and for parsing the manifested from latent content. While visual analysis of eWOM may be cumbersome, due to high context dependence and the vast amount of information to be analyzed, it may yield high rewards. Farace et al. (2017) recently described sharing visual content as a global phenomenon, and consumers and marketing practitioners are increasingly expressing interest in this format. For example, Xu et al. (2015) find that consumers perceive visual information as more credible, helpful, and persuasive than textual eWOM. However, methodological tools and issues, as well as broader implications of non-textual eWOM on the marketplace and consumer culture, have not yet been discussed.

4. Explore the impact of heuristic eWOM evaluation. As noted previously, consumers often rely on peripheral eWOM cues, such as review helpfulness votes (Ghose and Ipeirotis 2011). Knowledge has accumulated in the past decade on consumers’ motivations (e.g., low involvement) for heuristic eWOM evaluation and reliance on others' judgment; however, little is known about its consequences. Limited research in this area shows that such online heuristics can reinforce consumer biases, ultimately hindering their decision making (Risselada et al. 2018). Future research could explore whether consumers are more satisfied with their product 
choice when they rely on more helpful reviews. Do consumers believe they are making better, less risky decisions in such cases? In turn, does such reliance on eWOM helpfulness votes lead to greater product satisfaction and fewer product returns?

\section{Conclusion}

In the past two decades, eWOM has remained a stable point of interest and inquiry. Perhaps because of its unwaning popularity as a research topic fueled by continuous evolution of the phenomenon due to technological, social, and cultural developments, academic literature became fragmented in light of eWOM definitions and conceptual labels. Moreover, the multi-faceted nature of eWOM complicates the integration of findings, which affects future research. This article discusses these complexities through a “conceptual-empirical blend” (MacInnis 2011) that provides (1) an updated view of eWOM, (2) key research findings organized in a three-stage eWOM process, and (3) a research agenda made timely by the many expansions of eWOM in the fast-evolving digital environment. We organized prior work into a framework structured around consumer MOAs that we investigate along a three-stage non-linear eWOM process. For each stage, we describe key findings, identify relevant research gaps, and provide a roadmap for marketers to support consumers' MOA to (1) create, (2) be exposed to, and (3) evaluate eWOM.

In addressing the research gaps outlined herein, scholars should consider both the evolution of the eWOM phenomenon and eWOM research per se. Technological developments will continue to affect all three stages of the eWOM process, and eWOM formats will continue to change. For example, TechHive (2019) predicts that Bose’s augmented reality audio sunglasses will present eWOM in audial form, possibly affecting eWOM creation, exposure, and evaluation. Artificial intelligence is already influencing the exposure and evaluation of eWOM, making it more automated and data-driven. 
In addition to technological developments, from an economic perspective, eWOM is taking a central part in platform economics, from the news industry in which eWOM facilitates interactions between readers and journalists and guides further news consumption, to the sharing economy (e.g., HomeExchange) in which eWOM is at the heart of the business model (Dellaert 2019). In contexts in which eWOM has become big business, marketers are increasingly incentivized to influence, manage, and alter consumption-related communication among consumers. Thus, we wonder how much space there will be for organic eWOM. Will it change the heuristics that consumers use to seek out and evaluate eWOM? Will it lead them to view eWOM as persuasion attempts? In short, which new MOAs will emerge?

Finally, researchers should consider the impact of regulations on the eWOM phenomenon. Recent regulatory trends in business practices (e.g., the European Union’s General Data Protection Regulation 2016/6795) mandate a revision of marketers’ approaches to collecting and analyzing eWOM. This trend is also visible in research (e.g., INFORMS journals' data provenance and web-scraping restriction; Simchi-Levi 2019), thus affecting academic practice. Specifically, the ethics of tracking consumers' digital footprints represent a disruption to the collection and research of eWOM. In addition, consumers can now own and trade their own data in the data-driven economy (e.g., HAT—Hub of All Things; Ng and Wakenshaw 2017). Going forward, marketing scholars may be challenged for scraping the web for eWOM because of these privacy and ethics issues. The question of who owns online consumer data is quickly becoming a relevant one. In conclusion, eWOM is a dynamic phenomenon offering a rich well of research opportunities that is not likely to dry up soon.

\footnotetext{
${ }^{5}$ Regulation of the European Parliament and of the Council of the EU. Retrieved from https://publications. europa.eu/en/publication-detail/-/publication/3e485e15-11bd-11e6-ba9a-01aa75ed71a1/language-en.
} 


\section{References}

Abrantes, J.L., Seabra, C., Lages, C.R., \& Jayawardhena, C. (2013). Drivers of in-group and out-ofgroup electronic word-of-mouth (eWOM). European Journal of Marketing, 47(7), 10671088.

Adjei, M.T., Noble, S.M., \& Noble, C.H. (2010). The influence of C2C communications in online brand communities on customer purchase behavior. Journal of the Academy of Marketing Science, 38(5), 634-653.

Ahrens, J., Coyle, J.R., \& Strahilevitz, M.A. (2013). Electronic word of mouth: The effects of incentives on e-referrals by senders and receivers. European Journal of Marketing, 47(7), 1034-1051.

Akpinar, E., \& Berger, J. (2017). Valuable virality. Journal of Marketing Research, 54(2), 318-330.

Aksoy, L., Bloom, P.N., Lurie, N.H., \& Cooil, B. (2006). Should recommendation agents think like people? Journal of Service Research, 8(4), 297-315.

Aldo. (2017, June 20). "Í Í í í í ” - said YOU + Sale: Up to 50\% off. E-mail newsletter.

Algesheimer, R., Dholakia, U.M., \& Herrmann, A. (2005). The social influence of brand community: Evidence from European car clubs. Journal of Marketing, 69(3), 19-34.

Anderson, E.T., \& Simester, D.I. (2014). Reviews without a purchase: Low ratings, loyal customers, and deception. Journal of Marketing Research, 51(3), 249-269.

Anderson, M., \& Magruder, J. (2012). Learning from the crowd: Regression discontinuity estimates of the effects of an online review database. The Economic Journal, 122(563), 957-989.

Arvidsson, A., \& Caliandro, A. (2016). Brand public. Journal of Consumer Research, 42(5), $727-$ 748.

Ashley, C., \& Leonard, H.A. (2009). Betrayed by the buzz? Covert content and consumer-brand relationships. Journal of Public Policy \& Marketing, 28(2), 212-220.

Ashley, C., \& Tuten, T. (2015). Creative strategies in social media marketing: An exploratory study of branded social content and consumer engagement. Psychology \& Marketing, 32(1), 15-27.

Awad, N.F., \& Ragowsky, A. (2008). Establishing trust in electronic commerce through online word of mouth: An examination across genders. Journal of Management Information Systems, 24(4), 101-121.

Babić Rosario, A., Sotgiu, F., De Valck, K., \& Bijmolt, T.H.A. (2016). The effect of electronic word of mouth on sales: A meta-analytic review of platform, product, and metric factors. Journal of Marketing Research, 53(3), 297-318.

Baek, H., Ahn, J., \& Choi, Y. (2012). Helpfulness of online consumer reviews: Readers' objectives and review cues. International Journal of Electronic Commerce, 17(2), 99-126.

Bailey, A.A. (2005). Consumer awareness and use of product review websites. Journal of Interactive Advertising, 6(1), 68-81.

Batra, R., \& Keller, K.L. (2016). Integrating marketing communications: New findings, new lessons, and new ideas. Journal of Marketing, 80(6), 122-145.

Bean, J., Khorramian, A., \& O’Donnell, K. (2018). Kinfolk magazine: Anchoring a taste regime. Consumption Markets \& Culture, 21(1), 82-92.

Beckers, S.F., Van Doorn, J., \& Verhoef, P.C. (2018). Good, better, engaged? The effect of company-initiated customer engagement behavior on shareholder value. Journal of the Academy of Marketing Science, 46(3), 366-383.

Belk, R.W. (2013). Extended self in a digital world. Journal of Consumer Research, 40(3), 477-500.

Berger, J. (2014). Word of mouth and interpersonal communication: A review and directions for future research. Journal of Consumer Psychology, 24(4), 586-607.

Berlo, D.K. (1960). The process of communication: An introduction to theory and practice. New York, NY: Holt, Rinehart, and Winston. 
Berthon, P., Pitt, L., \& Campbell, C. (2008). Ad lib: When customers create the ad. California Management Review, 50(4), 6-30.

Beyens, I., Frison, E., \& Eggermont, S. (2016). “I don’t want to miss a thing”: Adolescents' fear of missing out and its relationship to adolescents' social needs, Facebook use, and Facebook related stress. Computers in Human Behavior, 64(November), 1-8.

Bikhchandani, S., Hirshleifer, D., \& Welch, I. (1998). Learning from the behavior of others: Conformity, fads, and informational cascades. Journal of Economic Perspectives, 12(3), 151170.

Brandes, L., Nolte, I., \& Nolte, S. (2011). "Where do the Joneses go on vacation? Social distance and the influence of online reviews on product sales.” Working paper, University of Lucerne.

Breugelmans, E., Bijmolt, T.H.A., Zhang, J., Basso, L.J., Dorotic, M., Kopalle, P., Minnema, A., Mijnlieff, W.J., \& Wünderlich, N.V. (2015). Advancing research on loyalty programs: A future research agenda. Marketing Letters, 26(2), 127-139.

Bronner, F., \& De Hoog, R. (2011). Vacationers and eWOM: Who posts, and why, where, and what? Journal of Travel Research, 50(1), 15-26.

Brooks Jr., R.C. (1957). “Word-of-mouth” advertising in selling new products. Journal of Marketing, 22(2), 154-161.

Brown, J.J., \& Reingen, P.H. (1987). Social ties and word-of-mouth referral behavior. Journal of Consumer Research, 14(3), 350-362.

Bruce, N.I., Foutz, N.Z., \& Kolsarici, C. (2012). Dynamic effectiveness of advertising and word of mouth in sequential distribution of new products. Journal of Marketing Research, 49(4), 469486.

Cadario, R. (2015). The impact of online word-of-mouth on television show viewership: An inverted u-shaped temporal dynamic. Marketing Letters, 26(4), 411-422.

Capoccia, C. (2018). Online reviews are the best thing that ever happened to small businesses. Forbes. April 11. Retrieved February 2, 2019 from

https://www.forbes.com/sites/forbestechcouncil/2018/04/11/online-reviews-are-the-best-thingthat-ever-happened-to-small-businesses/.

Carr, C.T., \& Hayes, R.A. (2014). The effect of disclosure of third-party influence on an opinion leader's credibility and electronic word of mouth in two-step flow. Journal of Interactive Advertising, 14(1), 38-50.

Chatterjee, P. (2011). Drivers of new product recommending and referral behaviour on social network sites. International Journal of Advertising, 30(1), 77-101.

Chen, Z., \& Berger, J. (2016). How content acquisition method affects word of mouth. Journal of Consumer Research, 43(1), 86-102.

Chen, Y., Fay, S., \& Wang, Q. (2011a). The role of marketing in social media: How online consumer reviews evolve. Journal of Interactive Marketing, 25(2), 85-94.

Chen, Y., Wang, Q., \& Xie, J. (2011b). Online social interactions: A natural experiment on word of mouth versus observational learning. Journal of Marketing Research, 48(2), 238-254.

Chen, Y.-J., \& Godes, D. (2012). Rating with confidence: Rating certainty and word-of-mouth behavior. In Z. Gürhan-Canli, C. Otnes, \& R. (Juliet) Zhu (Eds.), Advances in consumer research (Vol. 40, pp. 228-231). Provo, UT: Association for Consumer Research.

Chen, Z., \& Berger, J. (2013). When, why, and how controversy causes conversation. Journal of Consumer Research, 40(3), 580-593.

Cheung, C.M.K., \& Thadani, D.R. (2012). The impact of electronic word-of-mouth communication: A literature analysis and integrative model. Decision Support Systems, 54(1), 461-470.

Childers, T.L., \& Rao, A.R. (1992). The influence of familial and peer-based reference groups on consumer decisions. Journal of Consumer Research, 19(2), 198-211. 
Chintagunta, P.K., Gopinath, S., \& Venkataraman, S. (2010). The effects of online user reviews on movie box office performance: Accounting for sequential rollout and aggregation across local markets. Marketing Science, 29(5), 944-957.

Choi, J., Bell, D.R., \& Lodish, L.M. (2012). Traditional and IS-enabled customer acquisition on the Internet. Management Science, 58(4), 754-769.

Clemons, E.K., Gao, G.G., \& Hitt, L.M. (2006). When online reviews meet hyperdifferentiation: A study of the craft beer industry. Journal of Management Information Systems, 23(2), 149-171.

Dambrin, C., \& De Valck, K. (2007). Look who’s talking! Technology-supported impression formation in virtual communities. In G. Fitzsimons \& V. Morwitz (Eds.), Advances in consumer research (Vol. 34, pp. 450-453). Duluth, MN: Association for Consumer Research.

Daugherty, T., Eastin, M.S., \& Bright, L. (2008). Exploring consumer motivations for creating usergenerated content. Journal of Interactive Advertising, 8(2), 1-24.

De Haan, E., Kannan, P.K., Verhoef, P.C., \& Wiesel, T. (2018). Device switching in online purchasing: Examining the strategic contingencies. Journal of Marketing, 82(5), 1-19.

De Valck, K., Van Bruggen, G.H., \& Wierenga, B. (2009). Virtual communities: A marketing perspective. Decision Support Systems, 47(3), 185-203.

Dellaert, B.G. (2019). The consumer production journey: Marketing to consumers as co-producers in the sharing economy. Journal of the Academy of Marketing Science, 47(2), 238-254.

Dellarocas, C. (2003). The digitization of word of mouth: Promise and challenges of online feedback mechanisms. Management Science, 49(10), 1407-1424.

Dhar, V., \& Chang, E.A. (2009). Does chatter matter? The impact of user-generated content on music sales. Journal of Interactive Marketing, 23(4), 300-307.

Dholakia, U.M., Bagozzi, R.P., \& Pearo, L.K. (2004). A social influence model of consumer participation in network- and small-group-based virtual communities. International Journal of Research in Marketing, 21(3), 241-263.

Dichter, E. (1966). How word-of-mouth advertising works. Harvard Business Review, 44(6), 147166.

Dillard, J.P., Shen, L., \& Vail, R.G. (2007). Does perceived message effectiveness cause persuasion or vice versa? 17 consistent answers. Human Communication Research, 33(4), 467-488.

Dinçer, M.Z., \& Alrawadieh, Z. (2017). Negative word of mouse in the hotel industry: A content analysis of online reviews on luxury hotels in Jordan. Journal of Hospitality Marketing \& Management, 26(8), 785-804.

Dose, D.B., Walsh, G., Beatty, S.E., \& Elsner, R. (2019). Unintended reward costs: The effectiveness of customer referral reward programs for innovative products and services. Journal of the Academy of Marketing Science, 47(3), 438-459.

Du Plessis, C., Stephen, A.T., Bart, Y., \& Goncalves, D. (2014). When paying does (not) pay off: Incentivized consumer-generated product reviews and avoiding disclosure-induced backlash. Working paper, INSEAD.

Eelen, J., Özturan, P., \& Verlegh, P.W. (2017). The differential impact of brand loyalty on traditional and online word of mouth: The moderating roles of self-brand connection and the desire to help the brand. International Journal of Research in Marketing, 34(4), 872-891.

Eisingerich, A.B., Chun, H.H., Liu, Y., Jia, H., \& Bell, S.J. (2015). Why recommend a brand face-toface but not on Facebook? How word-of-mouth on online social sites differs from traditional word-of-mouth. Journal of Consumer Psychology, 25(1), 120-28.

Farace, S., Van Laer, T., De Ruyter, K., \& Wetzels, M. (2017). Assessing the effect of narrative transportation, portrayed action, and photographic style on the likelihood to comment on posted selfies. European Journal of Marketing, 51(11/12), 1961-1979. 
Federal Trade Commission. (2017, September 7). The FTC's endorsement guides: What people are asking. Retrieved March 3, 2019, from https://www.ftc.gov/tips-advice/businesscenter/guidance/ftcs-endorsement-guides-what-people-are-asking.

Filieri, R. (2015). What makes online reviews helpful? A diagnosticity-adoption framework to explain informational and normative influences in e-WOM. Journal of Business Research, 68(6), 1261-1270.

Floyd, K., Freling, F., Alhogail, S., Cho, H.Y., \& Freling, T. (2014). How online product reviews affect retail sales: A meta-analysis. Journal of Retailing, 90(2), 217-232.

Fong, J., \& Burton, S. (2008). A cross-cultural comparison of electronic word-of-mouth and countryof-origin effects. Journal of Business Research, 61(3), 233-242.

Forman, C., Ghose, A., \& Wiesenfeld, B. (2008). Examining the relationship between reviews and sales: The role of reviewer identity disclosure in electronic markets. Information Systems Research, 19(3), 291-313.

Fox, A. K., Deitz, G. D., Royne, M. B., \& Fox, J. D. (2018). The face of contagion: Consumer response to service failure depiction in online reviews. European Journal of Marketing, 52(1/2), 39-65.

Garnefeld, I., Iseke, A., \& Krebs, A. (2012). Explicit incentives in online communities: Boon or bane? International Journal of Electronic Commerce, 17(1), 11-38.

Ghose, A., \& Ipeirotis, P.Q. (2011). Estimating the helpfulness and economic impact of product reviews: Mining text and reviewer characteristics. IEEE Transactions on Knowledge and Data Engineering, 23(10), 1498-1512.

Ghose, A., Ipeirotis, P.G., \& Li, B. (2012). Designing ranking systems for hotels on travel search engines by mining user-generated and crowdsourced content. Marketing Science, 31(3), 493520.

Ghose, A., Ipeirotis, P.G., \& Li, B. (2014). Examining the impact of ranking on consumer behavior and search engine revenue. Management Science, 60(7), 1632-1654.

Godes, D., \& Mayzlin, D. (2009). Firm-created word-of-mouth communication: Evidence from a field test. Marketing Science, 28(4), 721-739.

Godes, D., \& Silva, J.C. (2012). Sequential and temporal dynamics of online opinion. Marketing Science, 31(3), 448-473.

Goldberg, J. (2018, October 3). What competitors are missing about Amazon's new 4-star retail concept. Forbes. Retrieved November 14, 2018, from https://www.forbes.com/sites/jasongoldberg/2018/10/03/what-competitors-are-missing-aboutamazons-new-4-star-retail-concept/.

Goldsmith, R.E., \& Horowitz, D. (2006). Measuring motivations for online opinion seeking. Journal of Interactive Advertising, 6(2), 2-14.

Gong, W., \& Li, X. (2017). Engaging fans on microblog: the synthetic influence of parasocial interaction and source characteristics on celebrity endorsement. Psychology \& Marketing, 34(7), 720-732.

Gong, S., Zhang, J., Zhao, P., \& Jiang, X. (2017). Tweeting as a marketing tool: A field experiment in the TV industry. Journal of Marketing Research, 54(6), 833-850.

Granovetter, M.S. (1973). The strength of weak ties. American Journal of Sociology, 78(6), 13601380.

Grewal, L., \& Stephen, A. T. (2019). In mobile we trust: The effects of mobile versus nonmobile reviews on consumer purchase intentions. Journal of Marketing Research, https://doi.org/10.1177/0022243719834514.

Grewal, R., Mehta, R., \& Kardes, F.R. (2004). The timing of repeat purchases of consumer durable goods: The role of functional bases of consumer attitudes. Journal of Marketing Research, 41(1), 101-115. 
Gruen, T.W., Osmonbekov, T., \& Czaplewski, A.J. (2006). eWOM: The impact of customer-tocustomer online know-how exchange on customer value and loyalty. Journal of Business Research, 59(4), 449-456.

Gruner, R.L., Homburg, C., \& Lukas, B.A. (2014). Firm-hosted online brand communities and new product success. Journal of the Academy of Marketing Science, 42(1), 29-48.

Gupta, P., \& Harris, J. (2010). How e-WOM recommendations influence product consideration and quality of choice: A motivation to process information perspective. Journal of Business Research, 63(9-10), 1041-1049.

Gursoy, D. (2019). A critical review of determinants of information search behavior and utilization of online reviews in decision making process. International Journal of Hospitality Management, 76, 53-60.

Hamilton, R.W., \& Price, L.L. (2019). Consumer journeys: Developing consumer-based strategy. Journal of the Academy of Marketing Science, 47(2), 187-191.

Hamilton, R.W., Schlosser, A., \& Chen, Y.-J. (2017). Who's driving this conversation? Systematic biases in the content of online consumer discussions. Journal of Marketing Research, 54(August), 540-555.

Hansen, R., \& Sia, S.K. (2015). Hummel's digital transformation toward omnichannel retailing: Key lessons learned. MIS Quarterly Executive, 14(2), 51-66.

Hanson, S., Jiang, L., \& Dahl, D. (2019). Enhancing consumer engagement in an online brand community via user reputation signals: A multi-method analysis. Journal of the Academy of Marketing Science, 47(2), 349-367.

Hayes, J.L., King, K.W., \& Ramirez Jr., A. (2016). Brands, friends, \& viral advertising: A social exchange perspective on the ad referral processes. Journal of Interactive Marketing, 36(November), 31-45.

Hennig-Thurau, T., Gwinner, K.P., Walsh, G., \& Gremler, D.D. (2004). Electronic word of mouth via consumer-opinion platforms: What motivates consumers to articulate themselves on the Internet? Journal of Interactive Marketing, 18(1), 38-52.

Hennig-Thurau, T., Wiertz, C., \& Feldhaus, F. (2015). Does Twitter matter? The impact of microblogging word of mouth on consumers' adoption of new movies. Journal of the Academy of Marketing Science, 43(3), 375-394.

Hildebrand, C. \& Schlager, T. (2019). Focusing on others before you shop: Exposure to Facebook promotes conventional product configurations. Journal of the Academy of Marketing Science, 47(2), 291-307.

Ho-Dac, N.N., Carson, S.J., \& Moore, W. (2013). The effects of positive and negative online customer reviews: Do brand strength and category maturity matter? Journal of Marketing, 77(6), 37-53.

Hoffman, E., \& Daugherty, T. (2013). Is a picture always worth a thousand words? Attention to structural elements of eWOM for consumer brands within social media. In S. Botti \& A. Labroo (Eds.), Advances in consumer research, 41(1), 326-331. Duluth, MN: Association for Consumer Research.

Hoffman, D.L., \& Novak, T.P. (1996). Marketing in hypermedia computer-mediated environments: Conceptual foundations. Journal of Marketing, 60(3), 50-68.

Homburg, C., Ehm, L., \& Artz, M. (2015). Measuring and managing consumer sentiment in an online community environment. Journal of Marketing Research, 52(5), 629-641.

Hong, H., Xu, D., Wang, G.A., \& Fan, W. (2017). Understanding the determinants of online review helpfulness: A meta-analytic investigation. Decision Support Systems, 102(October), 1-11.

Internet World Stats. (2017). Facebook World Stats and Penetration in the World. Retrieved January 24, 2019, from http://www.internetworldstats.com/facebook.htm. 
Jiang, Y., \& Guo, H. (2015). Design of consumer review systems and product pricing. Information Systems Research, 26(4), 714-730.

Jiménez, F.R., \& Mendoza, N.A. (2013). Too popular to ignore: The influence of online reviews on purchase intentions of search and experience products. Journal of Interactive Marketing, 27(3), 226-235.

Kannan, P.K., \& Li, H. (A.) (2017). Digital marketing: A framework, review and research agenda. International Journal of Research in Marketing, 34(1), 22-45.

Karniouchina, E. V. (2011). Impact of star and movie buzz on motion picture distribution and box office revenue. International Journal of Research in Marketing, 28(1), 62-74.

Katz, E. \& Lazarsfeld, P.F. (1955). Personal influence: The part played by people in the flow of mass communications. Glencoe, IL: The Free Press.

Keller, E., \& Fay, B. (2012). Word-of-mouth advocacy: A new key to advertising effectiveness. Journal of Advertising Research, 52(4), 459-464.

Kim, A.J., \& Ko, E. (2012). Do social media marketing activities enhance customer equity? An empirical study of luxury fashion brand. Journal of Business Research, 65(10), 1480-1486.

Kim, J., Naylor, G., Sivadas, E., \& Sugumaran, V. (2016). The unrealized value of incentivized eWOM recommendations. Marketing Letters, 27(3), 411-421.

Kim, Y., \& Slotegraaf, R.J. (2015). Brand-embedded interaction: A dynamic and personalized interaction for co-creation. Marketing Letters, 27(1), 183-93.

King, R.A., Racherla, P., \& Bush, V.D. (2014). What we know and don't know about online wordof-mouth: A review and synthesis of the literature. Journal of Interactive Marketing, 28(3), 167-183.

Kozinets, R.V. (1999). E-tribalized marketing? The strategic implications of virtual communities of consumption. European Management Journal, 17(3), 252-264.

Kozinets, R.V. (2002). The field behind the screen: Using netnography for marketing research in online communities. Journal of Marketing Research, 39(1), 61-72.

Kozinets, R.V. (2016). Amazonian forests and trees: Multiplicity and objectivity in studies of online consumer-generated ratings and reviews, a commentary on De Langhe, Fernbach, and Lichtenstein. Journal of Consumer Research, 42(April), 834-839.

Kozinets, R.V., De Valck, K., Wojnicki, A.C., \& Wilner, S.J. (2010). Networked narratives: Understanding word-of-mouth marketing in online communities. Journal of Marketing, 74(2), 71-89.

Kozinets, R.V., \& Handelman, J.M. (2004). Adversaries of consumption: Consumer movements, activism, and ideology. Journal of Consumer Research, 31(3), 691-704.

Kübler, R., Pauwels, K., Yildirim, G., \& Fandrich, T. (2018). App popularity: Where in the world are consumers most sensitive to price and user ratings? Journal of Marketing, 82(5), 20-44.

Kumar, V., Bhaskaran, V., Mirchandani, R., \& Shah, M. (2013). Creating a measurable social media marketing strategy: Increasing the value and ROI of intangibles and tangibles for hokey pokey. Marketing Science, 32(2), 194-212.

Kuo, H.-C., \& Nakhata, C. (2019). The impact of electronic word-of-mouth on customer satisfaction. Journal of Marketing Theory and Practice, 27(3), 331-348.

Kupfer, A.-K., Pähler vor der Holte, N., Kübler, R.V., \& Hennig-Thurau, T. (2018). The role of the partner brand's social media power in brand alliances. Journal of Marketing, 82(3), 25-44.

Kushwaha, T., \& Shankar, V. (2013). Are multichannel customers really more valuable? The moderating role of product category characteristics. Journal of Marketing, 77(4), 67-85.

Kusumasondjaja, S., Shanka, T., \& Marchegiani, C. (2012). Credibility of online reviews and initial trust: The roles of reviewer's identity and review valence. Journal of Vacation Marketing, 18(3), 185-195. 
Lamberton, C.P., \& Stephen, A.T. (2016). A thematic exploration of digital, social media, and mobile marketing research's evolution from 2000 to 2015 and an agenda for future research. Journal of Marketing, 80(6), 146-172.

Langan, R., Besharat, A., \& Varki, S. (2017). The effect of review valence and variance on product evaluations: An examination of intrinsic and extrinsic cues. International Journal of Research in Marketing, 34(2), 414-429.

Langley, D.J., Hoeve, M.C., Ortt, J., Pals, N., \& Van Der Vecht, B. (2014). Patterns of herding and their occurrence in an online setting. Journal of Interactive Marketing, 28(1), 16-25.

Lappas, T., Sabnis, G., \& Valkanas, G. (2016). The impact of fake reviews on online visibility: A vulnerability assessment of the hotel industry. Information Systems Research, 27(4), 940-961.

Lee, J.Y., \& Bell, D.R. (2013). Neighborhood social capital and social learning for experience attributes of products. Marketing Science, 32(6), 960-976.

Lee, J., Park, D.-H., \& Han, I. (2008). The effect of negative online consumer reviews on product attitude: An information processing view. Electronic Commerce Research and Applications, 7(3), 341-352.

Lee, S.-H., \& Workman, J.E. (2014). Gossip, self-monitoring and fashion leadership: Comparison of US and South Korean consumers. Journal of Consumer Marketing, 31(6/7), 452-463.

Lee, T.Y., \& Bradlow, E.T. (2011). Automated marketing research using online customer reviews. Journal of Marketing Research, 48(5), 881-894.

Lemon, K.N., \& Verhoef, P.C. (2016). Understanding customer experience throughout the customer journey. Journal of Marketing, 80(6), 69-96.

Li, Y.-M., Lin, L., \& Chiu, S.-W. (2014). Enhancing targeted advertising with social context endorsement. International Journal of Electronic Commerce, 19(1), 99-128.

Libai, B., Bolton, R., Bügel, M.S., De Ruyter, K., Götz, O., Risselada, H., \& Stephen, A.T. (2010). Customer-to-customer interactions: Broadening the scope of word of mouth research. Journal of Service Research, 13(3), 267-282.

Liousas, E.A. (2018). Ratings \& reviews: What's old should be new again. Forrester Research Blog. March 16. Retrieved December 12, 2018 from https://go.forrester.com/blogs/whats-old-shouldbe-new-again/.

Lipsman, A., Mudd, G., Rich, M., \& Bruich, S. (2012). The power of "Like”: How brands reach (and influence) fans through social-media marketing. Journal of Advertising Research, 52(1), 4052.

Litvin, S.W., Goldsmith, R.E., \& Pan, B. (2008). Electronic word-of-mouth in hospitality and tourism management. Tourism Management, 29(3), 458-468.

Liu, Y. (2006). Word of mouth for movies: Its dynamics and impact on box office revenue. Journal of Marketing, 70(3), 74-89.

Liu, H., Lurie, N., \& Ransbotham, S. (2013). The content and impact of mobile versus desktop reviews. In S. Botti \& A. Labroo (Eds), Advances in consumer research (Vol. 41, p. 117). Duluth, MN: Association for Consumer Research.

Lovett, M.J., Peres, R., \& Shachar, R. (2013). On brands and word of mouth. Journal of Marketing Research, 50(4), 427-444.

Lu, Y., Jerath, K., \& Singh, P.V. (2013). The emergence of opinion leaders in a networked online community: A dyadic model with time dynamics and a heuristic for fast estimation. Management Science, 59(8), 1783-1799.

Ludwig, S., De Ruyter, K., Friedman, M., Brüggen, E.C., Wetzels, M., \& Pfann, G. (2013). More than words: The influence of affective content and linguistic style matches in online reviews on conversion rates. Journal of Marketing, 77(1), 87-103.

MacInnis, D.J. (2011). A framework for conceptual contributions in marketing. Journal of Marketing, 75(4), 136-154. 
MacInnis, D.J., Moorman, C., \& Jaworski, B.J. (1991). Enhancing and measuring consumers’ motivation, opportunity, and ability to process brand information from ads. Journal of Marketing, 55(4), 32-53.

Mafael, A., Gottschalk, S.A., \& Kreis, H. (2016). Examining biased assimilation of brand-related online reviews. Journal of Interactive Marketing, 36, 91-106.

Marchand, A., Hennig-Thurau, T., \& Wiertz, C. (2017). Not all digital word of mouth is created equal: Understanding the respective impact of consumer reviews and microblogs on new product success. International Journal of Research in Marketing, 34(2), 336-354.

Mariani, M.M., Borghi, M., \& Gretzel, U. (2019). Online reviews: Differences by submission device. Tourism Management, 70(February), 295-298.

Marketing Science Institute. (2018). 2018-2020 Research Priorities: Marketers' strategic imperatives. Retrieved January 13, 2019, from https://www.msi.org/articles/marketers-top-challenges-20182020-research-priorities.

März, A., Schubach, S., \& Schumann, J.H. (2017). “Why would I read a mobile review?” Device compatibility perceptions and effects on perceived helpfulness. Psychology \& Marketing, 34(2), 119-137.

Mathwick, C., Wiertz, C., \& De Ruyter, K. (2008). Social capital production in a virtual P3 community. Journal of Consumer Research, 34(6), 832-849.

Mayzlin, D. (2006). Promotional chat on the Internet. Marketing Science, 25(2), 155-163.

Mayzlin, D., Dover, Y., \& Chevalier, J. (2014). Promotional reviews: An empirical investigation of online review manipulation. American Economic Review, 104(8), 2421-2455.

McAlexander, J.H., Schouten, J.W., \& Koenig, H.F. (2002). Building brand community. Journal of Marketing, 66(1), 38-54.

McQuarrie, E. F., Miller, J., \& Phillips, B. J. (2013). The megaphone effect: Taste and audience in fashion blogging. Journal of Consumer Research, 40(1), 136-158.

McGraw, A.P., Warren, C., \& Kan, C. (2015). Humorous complaining. Journal of Consumer Research, 41(5), 1153-1171.

Melumad, S., Inman, J.J., \& Pham, M.T. (2019). Selectively emotional: How smartphone use changes user-generated content. Journal of Marketing Research, 56(2), 259-275.

Miller, C.M., McIntyre, S.H., \& Mantrala, M.K. (1993). Toward formalizing fashion theory. Journal of Marketing Research, 30(2), 142-157.

Minnema, A., Bijmolt, T.H.A., Gensler, S., \& Wiesel, T. (2016). To keep or not to keep: Effects of online customer reviews on product returns. Journal of Retailing, 92(3), 253-267.

Mix.com. (2019). Curate the best of the Internet. Retrieved May 21, 2019, from http://mix.com.

Moe, W.W., \& Schweidel, D.A. (2012). Online product opinions: Incidence, evaluation, and evolution. Marketing Science, 31(3), 372-386.

Moe, W.W., \& Trusov, M. (2011). The value of social dynamics in online product ratings forums. Journal of Marketing Research, 48(3), 444-456.

Moran, G., Muzellec, L., \& Nolan, E. (2014). Consumer moments of truth in the digital context: How "search" and "e-word of mouth" can fuel consumer decision making. Journal of Advertising Research, 54(2), 200-204.

Motyka, S., Grewal, D., Aguirre, E., Mahr, D., De Ruyter, K., \& Wetzels, M. (2018). The emotional review-reward effect: How do reviews increase impulsivity? Journal of the Academy of Marketing Science, 46(6), 1032-1051.

Mudambi, S.M., \& Schuff, D. (2010). What makes a helpful online review? A study of customer reviews on Amazon.com. MIS Quarterly, 34(1), 185-200.

Nam, H., \& Kannan, P.K. (2014). The informational value of social tagging networks. Journal of Marketing, 78(4), 21-40. 
Naylor, R.W., Lamberton, C.P., \& West, P.M. (2012). Beyond the "Like” button: The impact of mere virtual presence on brand evaluations and purchase intentions in social media settings. Journal of Marketing, 76(6), 105-120.

Ng, I.C.L., \& Wakenshaw, S.Y.L. (2017). The Internet-of-Things: Review and research directions. International Journal of Research in Marketing, 34(1), 3-21.

Okleshen, C., \& Grossbart, S. (1998). Usenet groups, virtual community and consumer behaviors. In J.W. Alba \& J.W. Hutchinson (Eds.), Advances in consumer research (Vol. 25, pp. 276-282). Provo, UT: Association for Consumer Research.

Palmatier, R.W., Dant, R.P., Grewal, D., \& Evans, K.R. (2006). Factors influencing the effectiveness of relationship marketing: A meta-analysis. Journal of Marketing, 70(4), 136-153.

Park, H.H., \& Jeon, J. O. (2018). The impact of mixed eWOM sequence on brand attitude change: Cross-cultural differences. International Marketing Review, 35(3), 390-411.

Park, D.-H., Lee, J., \& Han, I. (2007). The effect of on-line consumer reviews on consumer purchasing intention: The moderating role of involvement. International Journal of Electronic Commerce, 11(4), 125-148.

Pauwels, K., Aksehirli, Z., \& Lackman, A. (2016). Like the ad or the brand? Marketing stimulates different electronic word-of-mouth content to drive online and offline performance. International Journal of Research in Marketing, 33(3), 639-655.

Pauwels, K., Leeflang, P.S., Teerling, M.L., \& Huizingh, K.E. (2011). Does online information drive offline revenues? Only for specific products and consumer segments! Journal of Retailing, 87(1), 1-17.

Peters, K., Chen, Y., Kaplan, A.M., Ognibeni, B., \& Pauwels, K. (2013). Social media metrics: A framework and guidelines for managing social media. Journal of Interactive Marketing, 27(4), 281-298.

Pfeffer, J., Zorbach, T., \& Carley, K.M. (2014). Understanding online firestorms: Negative word-ofmouth dynamics in social media networks. Journal of Marketing Communications, 20(1-2), 117-128.

Pinch, T. \& Kesler, F. (2011). How aunt Amy gets her free lunch: A study of the top-thousand customer reviewers at Amazon.com. In B. Czarniawska \& O. Lofgren (Eds.), Managing Overflow in Affluent Societies. New York, NY: Routledge.

Piramuthu, S., Kapoor, G., Zhou, W., \& Mauw, S. (2012). Input online review data and related bias in recommender systems. Decision Support Systems, 53(3), 418-424.

Poch, R., \& Martin, B. (2015). Effects of intrinsic and extrinsic motivation on user-generated content. Journal of Strategic Marketing, 23(4), 305-317.

Pühringer, S., \& Taylor, A. (2008). A practitioner's report on blogs as a potential source of destination marketing intelligence. Journal of Vacation Marketing, 14(2), 177-187.

Rapp, A., Beitelspacher, L.S., Grewal, D., \& Hughes, D.E. (2013). Understanding social media effects across seller, retailer, and consumer interactions. Journal of the Academy of Marketing Science, 41(5), 547-566.

Relling, M., Schnittka, O., Sattler, H., \& Johnen, M. (2016). Each can help or hurt: Negative and positive word of mouth in social network brand communities. International Journal of Research in Marketing, 33(1), 42-58.

Risselada, H., De Vries, L., \& Verstappen, M. (2018). The impact of social influence on the perceived helpfulness of online consumer reviews. European Journal of Marketing, 52(3/4), 619-636.

Rui, H., Liu, Y., \& Whinston, A.B. (2013). Whose and what chatter matters? The impact of tweets on movie sales. Decision Support Systems, 55(4), 863-870.

Rutz, O.J., \& Bucklin, R.E. (2011). From generic to branded: A model of spillover in paid search advertising. Journal of Marketing Research, 48(1), 87-102. 
Salwen, M. \& Sacks, D.W. (2008). An integrated approach to communication theory and research. Mahwah, NJ: Routledge.

Schamari, J., \& Schaefers, T. (2015). Leaving the home turf: How brands can use webcare on consumer-generated platforms to increase positive consumer engagement. Journal of Interactive Marketing, 30, 20-33.

Schau, H.J., Muñiz, A.M., \& Arnould, E.J. (2009). How brand community practices create value. Journal of Marketing, 73(5), 30-51.

Schlosser, A.E. (2005). Posting versus lurking: Communicating in a multiple audience context. Journal of Consumer Research, 32(2), 260-265.

Schmidt, J.B., \& Spreng, R.A. (1996). A proposed model of external consumer information search. Journal of the Academy of Marketing Science, 24(3), 246-256.

Schuckert, M., Liu, X., \& Law, R. (2015). Hospitality and tourism online reviews: Recent trends and future directions. Journal of Travel \& Tourism Marketing, 32(5), 608-621.

Schulze, C., Schöler, L., \& Skiera, B. (2014). Not all fun and games: Viral marketing for utilitarian products. Journal of Marketing, 78(1), 1-19.

Schweidel, D.A., \& Moe, W.W. (2014). Listening in on social media: A joint model of sentiment and venue format choice. Journal of Marketing Research, 51(4), 387-402.

Shannon-Missal, L. (2013, January 3). Different priorities in smartphone vs. computer use, but some common ground. CISION PR Newswire, Retrieved April 27, 2019, from

https://www.prnewswire.com/news-releases/different-priorities-in-smartphone-vs-computeruse-but-some-common-ground-185534492.html.

Sibai, O., De Valck, K., Farrell, A.M., \& Rudd, J.M. (2015). Social control in online communities of consumption: A framework for community management. Psychology \& Marketing, 32(3), 250-264.

Simchi-Levi, D. (2019, January 18). From the Editor. Retrieved February 16, 2019, from https://www.informs.org/Blogs/ManSci-Blogs/From-the-Editor/From-the-Editor-January2019.

Simonson, I. (2016). Imperfect progress: An objective quality assessment of the role of user reviews in consumer decision making, a commentary on de Langhe, Fernbach, and Lichtenstein. Journal of Consumer Research, 42(6), 840-845.

Smith, A.N., Fischer, E., \& Yongjian, C. (2012). How does brand-related user-generated content differ across YouTube, Facebook, and Twitter? Journal of Interactive Marketing, 26(2), 102113.

Steffes, E.M., \& Burgee, L.E. (2009). Social ties and online word of mouth. Internet Research, 19(1), 42-59.

Stephen, A.T., \& Lehmann, D.R. (2016). How word-of-mouth transmission encouragement affects consumers' transmission decisions, receiver selection, and diffusion speed. International Journal of Research in Marketing, 33(4), 755-766.

Sun, Y., Dong, X., \& McIntyre, S. (2017). Motivation of user-generated content: Social connectedness moderates the effects of monetary rewards. Marketing Science, 36(3), 329-337.

Tang, T., Fang, E., \& Wang, F. (2014). Is neutral really neutral? The effects of neutral user-generated content on product sales. Journal of Marketing, 78(4), 41-58.

TechHive. (2019, February 1). Bose Frames review: Made in the shades. Retrieved March 15, 2019 from https://www.techhive.com/article/3337530/bose-frames-review.html.

Tellis, G.J., MacInnis, D.J., Tirunillai, S., \& Zhang, Y. (2019). What drives virality (sharing) of online digital content? The critical role of information, emotion, and brand prominence. Journal of Marketing, 83(4), 1-20.

Thompson, D.V., \& Malaviya, P. (2013). Consumer-generated ads: Does awareness of advertising co-creation help or hurt persuasion? Journal of Marketing, 77(3), 33-47. 
Thorson, K.S., \& Rodgers, S. (2006). Relationships between blogs as eWOM and interactivity, perceived interactivity, and parasocial interaction. Journal of Interactive Advertising, 6(2), 3444.

Tirunillai, S., \& Tellis, G.J. (2012). Does chatter really matter? Dynamics of user-generated content and stock performance. Marketing Science, 31(2), 198-215.

Townsend, C., Neal, D.T., \& Morgan, C. (2019). The impact of the mere presence of social media share icons on product interest and valuation. Journal of Business Research, 100(July), 245254.

Trusov, M., Bucklin, R.E., \& Pauwels, K. (2009). Effects of word-of-mouth versus traditional marketing: Findings from an internet social networking site. Journal of Marketing, 73(5), 90 102.

Von Wangenheim, F.V. (2005). Postswitching negative word of mouth. Journal of Service Research, 8(1), 67-78.

Wang, X., Yu, C., \& Wei, Y. (2012). Social media peer communication and impacts on purchase intentions: A consumer socialization framework. Journal of Interactive Marketing, 26(4), 198208.

Wang, Y., \& Chaudhry, A. (2018). When and how managers' responses to online reviews affect subsequent reviews. Journal of Marketing Research, 55(2), 163-177.

Warwick, C., Rimmer, J., Blandford, A., Gow, J., \& Buchanan, G. (2009). Cognitive economy and satisficing in information seeking: A longitudinal study of undergraduate information behavior. Journal of the American Society for Information Science and Technology, 60(12), 2402-2415.

Webster, J., \& Watson, R.T. (2002). Analyzing the past to prepare for the future: Writing a literature review. MIS Quarterly, 26(2), 13-23.

Wiertz, C., \& De Ruyter, K. (2007). Beyond the call of duty: Why customers contribute to firmhosted commercial online communities. Organization Studies, 28(3), 347-376.

Worldpay. (2017). For each of the following circumstances, how important is it to read online reviews before purchasing a product or selecting a service provider? Retrieved January 10, 2019, from http://www-statista-com.du.idm.oclc.org/statistics/713258/online-reviewimportance-circumstances-usa/.

$\mathrm{Xu}, \mathrm{P}$., Chen, L., \& Santhanam, R. (2015). Will video be the next generation of e-commerce product reviews? Presentation format and the role of product type. Decision Support Systems, 73(May), 85-96.

Yadav, M.S., De Valck, K., Hennig-Thurau, T., Hoffman, D.L., \& Spann, M. (2013). Social commerce: A contingency framework for assessing marketing potential. Journal of Interactive Marketing, 27(4), 311-323.

Yadav, M.S., \& Pavlou, P.A. (2014). Marketing in computer-mediated environments: Research synthesis and new directions. Journal of Marketing, 78(1), 20-40.

You, Y., Vadakkepatt, G.G., \& Joshi, A.M. (2015). A meta-analysis of electronic word-of-mouth elasticity. Journal of Marketing, 79(2), 19-39.

Zhao, Y., Yang, S., Narayan, V., \& Zhao, Y. (2013). Modeling consumer learning from online product reviews. Marketing Science, 32(1), 153-169.

Zhu, F., \& Zhang, X. (2010). Impact of online consumer reviews on sales: The moderating role of product and consumer characteristics. Journal of Marketing, 74(2), 133-148. 
Table 1 What eWOM is and is not: Definition of eWOM and related phenomena

\begin{tabular}{|c|c|c|c|c|c|c|}
\hline \multirow{2}{*}{$\begin{array}{l}\text { Original } \\
\text { Conceptual } \\
\text { Label }\end{array}$} & \multirow{2}{*}{ Definition } & \multirow{2}{*}{ Consumption } & \multicolumn{2}{|c|}{ Consumer } & \multirow[b]{2}{*}{ Digital } & \multirow{2}{*}{$\begin{array}{l}\text { Is } \\
\text { eWOM? }\end{array}$} \\
\hline & & & Sender & Receiver & & \\
\hline \multirow{6}{*}{ eWOM } & $\begin{array}{l}\text { 1. "eWOM communication [is] any positive or negative statement made by potential, actual, or former customers about a product } \\
\text { or company, which is made available to a multitude of people and institutions via the Internet [and which] can take place in many } \\
\text { ways (e.g., Web-based opinion platforms, discussion forums, boycott Web sites, news groups)" (Hennig-Thurau et al. 2004, p. 39). }\end{array}$ & $\mathrm{X}$ & $\mathrm{X}$ & $\mathrm{X}$ & $\mathrm{X}$ & Yes \\
\hline & $\begin{array}{l}\text { 2. eWOM referral is an invitation to others to join the social network using easy-to-use tools such as "import your address book" } \\
\text { (Trusov et al. 2009). }\end{array}$ & & & & $\mathrm{X}$ & \\
\hline & 3. eWOM is "positive or negative information about [a] product ... obtain[ed] from fellow consumers (Forman et al. 2008, p. 291). & $\mathrm{X}$ & $\mathrm{X}$ & $\mathrm{X}$ & & Yes \\
\hline & $\begin{array}{l}\text { 4. "eWOM can be defined as all informal communications directed at consumers through Internet-based technology related to the } \\
\text { usage or characteristics of particular goods and services, or their sellers" (Litvin et al. 2008, p. 461). }\end{array}$ & $\mathrm{X}$ & $\mathrm{X}$ & $\mathrm{X}$ & $\mathrm{X}$ & Yes \\
\hline & $\begin{array}{l}\text { 5. "eWOM involves consumers' comments about products and services posted on the Internet; for example, ... the rating on a 10- } \\
\text { point scale of a hotel and textual comments on the service and location" (Bronner and De Hoog 2011, p. 15). }\end{array}$ & $\mathrm{X}$ & $\mathrm{X}$ & & $\mathrm{X}$ & Yes \\
\hline & 6. "Online WOM includes referrals through online message boards, blogs, and online communities" (Choi et al. 2012, p. 758). & & $\mathrm{X}$ & & $\mathrm{X}$ & \\
\hline \multirow{3}{*}{ Reviews } & $\begin{array}{l}\text { 1. "[O]nline reviews, now often called simply “word of mouse” ... are available for ... virtually every imaginable [product] } \\
\text { category. While some of them are prepared by expert reviewers ..., increasingly reviews are prepared and posted by individuals } \\
\text { who have been profoundly delighted, or truly appalled, by an individual product or service experience” (Clemons et al. 2006, p. } \\
\text { 151). }\end{array}$ & $X$ & $\mathrm{X}$ & & $\mathrm{X}$ & Yes \\
\hline & $\begin{array}{l}\text { 2. "Online consumer reviews (OCRs), which are the electronic version of word of mouth, . . are enabling consumers to share their } \\
\text { experiences, opinions, and feedback regarding products, services, or brands ... for other consumers" (Filieri 2015, p. 1261). }\end{array}$ & $\mathrm{X}$ & $\mathrm{X}$ & $\mathrm{X}$ & $\mathrm{X}$ & Yes \\
\hline & $\begin{array}{l}\text { 3. "Online customer reviews can be defined as peer-generated product evaluations posted on company or third-party websites" } \\
\text { (Mudambi and Schuff 2010, p. 186). }\end{array}$ & $\mathrm{X}$ & $\mathrm{X}$ & $\mathrm{X}$ & $\mathrm{X}$ & Yes \\
\hline \multirow[b]{2}{*}{ UGC } & 1. UGC refers to "the conjunction of blogs and social networking sites" (Dhar and Chang 2009, p. 300). & & & & $\mathrm{X}$ & \\
\hline & $\begin{array}{l}\text { 2. UGC "refers to media content created or produced by the general public rather than by paid professionals and primarily } \\
\text { distributed on the Internet" (Daugherty et al. 2008, p. 16). }\end{array}$ & & $\mathrm{X}$ & & $\mathrm{X}$ & \\
\hline \multirow{2}{*}{$\begin{array}{l}\text { Consumer- } \\
\text { generated } \\
\text { ads }\end{array}$} & $\begin{array}{l}\text { 1. Consumer-generated ads are "any publicly disseminated, consumer-generated advertising messages whose subject is a } \\
\text { collectively recognized brand" (Berthon et al. 2008, p .8). }\end{array}$ & $\mathrm{X}$ & $\mathrm{X}$ & & & \\
\hline & $\begin{array}{l}\text { 2. "Consumer-generated advertising is ... defined to include any user-generated brand-related content, in the form of online brand } \\
\text { testimonials, product reviews, and user-generated commercials" (Salwen and Sacks 2008, p. 199). }\end{array}$ & $\mathrm{X}$ & $\mathrm{X}$ & & $\mathrm{X}$ & Yes \\
\hline \multirow{5}{*}{ Other } & 1. Buzz “involves informal communication among consumers about products and services” (Liu 2006, p. 74). & $\mathrm{X}$ & $\mathrm{X}$ & $\mathrm{X}$ & & \\
\hline & 2. Social voice is "online ... brand mentions and conversations ... among consumers" (Keller and Fay 2012, p. 462). & & $\mathrm{X}$ & $\mathrm{X}$ & $\mathrm{X}$ & \\
\hline & $\begin{array}{l}\text { 3. Consumer-to-consumer know-how exchange is "the interactions among individuals that serve as an information source that } \\
\text { enhances competency and knowledge" (Gruen et al. 2006, p. 451). }\end{array}$ & & $\mathrm{X}$ & $\mathrm{X}$ & & \\
\hline & $\begin{array}{l}\text { 4. Travel blogs are "individual entries which relate to planned, current or past travel [and are] commonly written by tourists to } \\
\text { report back to friends and families about activities and experiences during trips" (Pühringer and Taylor 2008, p. 179). }\end{array}$ & $\mathrm{X}$ & $\mathrm{X}$ & $\mathrm{X}$ & $\mathrm{X}$ & Yes \\
\hline & $\begin{array}{l}\text { 5. Virtual communities of consumption are "affiliative groups whose online interactions are based upon shared enthusiasm for, and } \\
\text { knowledge of, a specific consumption activity or related group of activities" (Kozinets 1999, p. 254). }\end{array}$ & $\mathrm{X}$ & & $\mathrm{X}$ & $X$ & Yes \\
\hline $\begin{array}{c}\text { Revised } \\
\text { definition }\end{array}$ & $\begin{array}{l}\text { eWOM is consumer-generated, consumption-related communication that employs digital tools and is directed primarily to } \\
\text { other consumers. }\end{array}$ & $X$ & $\mathrm{X}$ & $X$ & $X$ & Yes \\
\hline
\end{tabular}

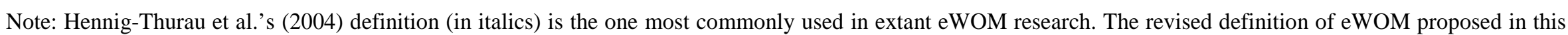
article is in bold. 


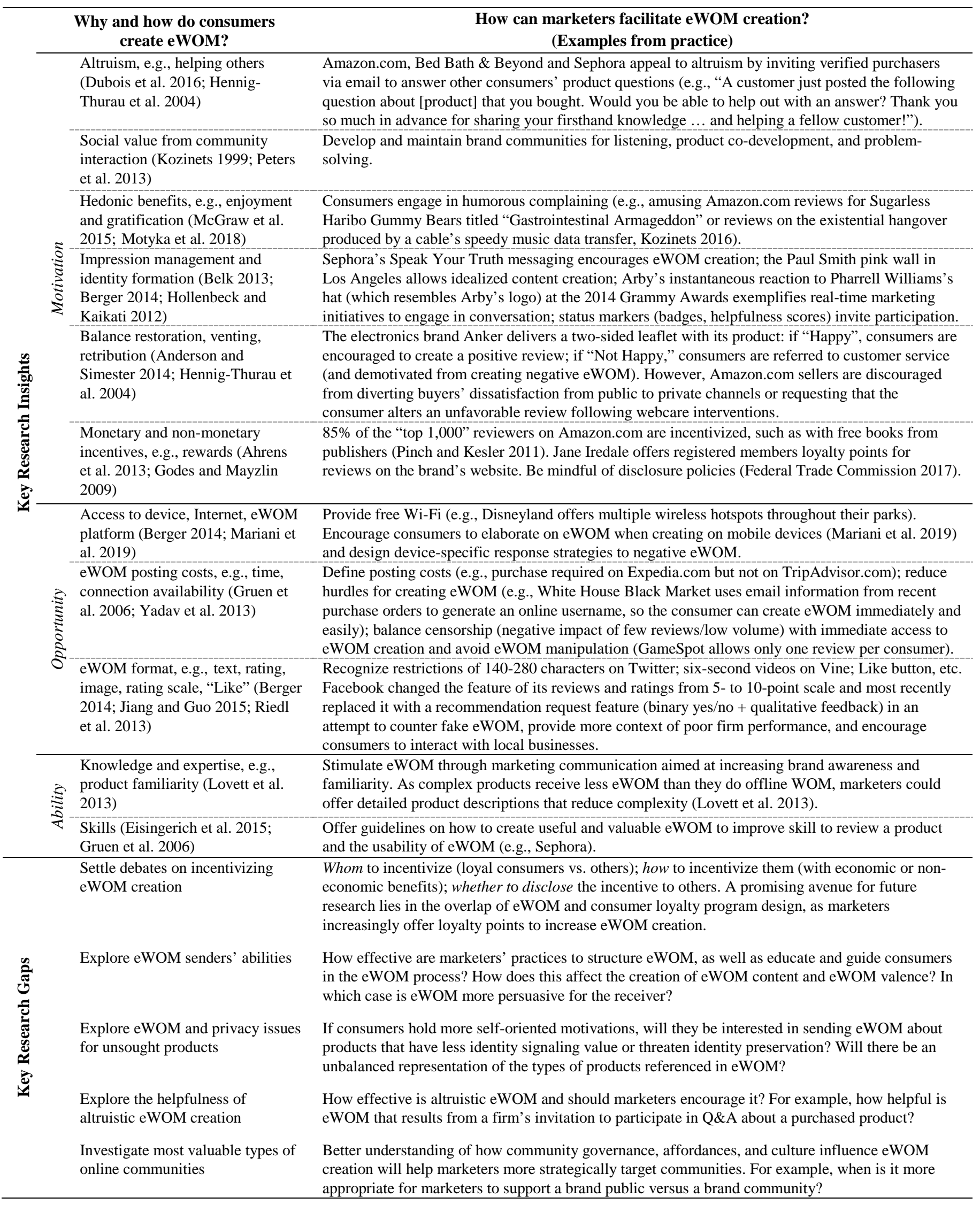


Table 3 Stage 2: eWOM exposure

\begin{tabular}{|c|c|c|c|}
\hline \multirow{10}{*}{ 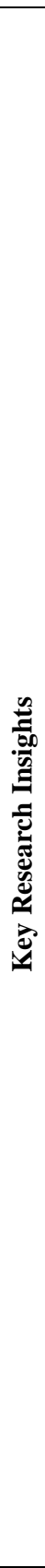 } & & $\begin{array}{l}\text { Why and how do consumers } \\
\text { search for and get exposed to eWOM? }\end{array}$ & $\begin{array}{l}\text { How can marketers facilitate eWOM exposure? } \\
\text { (Examples from practice) }\end{array}$ \\
\hline & \multirow{5}{*}{ 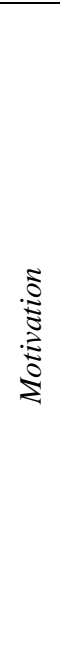 } & $\begin{array}{l}\text { Individual traits, e.g., high need for cognition } \\
\text { (Gupta and Harris 2010), perceived expertise, } \\
\text { market mavenism (Adjei et al. 2010) }\end{array}$ & $\begin{array}{l}\text { Invite consumers to check other shoppers' opinions (e.g., the shoe retailer Aldo [2017] } \\
\text { recently stated in its newsletter: “Don't just take our word for it, see what shoppers are } \\
\text { saying about these summer styles”). }\end{array}$ \\
\hline & & $\begin{array}{l}\text { Reduction of uncertainty and perceived risk } \\
\text { (Fong and Burton 2008; Hennig-Thurau et al. } \\
\text { 2004; Moe and Trusov 2011). }\end{array}$ & $\begin{array}{l}\text { Some platforms, such as StumbleUpon and Mix, attract consumers by showing them } \\
\text { "interesting content selected by friends and like-minded people” (Mix.com 2019). } \\
\text { Marketers should be aware that eWOM seeking may be culturally determined (e.g., } \\
\text { higher in China than U.S.; Fong and Burton 2008). }\end{array}$ \\
\hline & & $\begin{array}{l}\text { Reduction of cognitive dissonance in the } \\
\text { post-purchase stage (Bailey 2005), problem } \\
\text { solve (Mathwick et al. 2008) }\end{array}$ & $\begin{array}{l}\text { Dell has pioneered with offering discussion forums on their website that give customers } \\
\text { access to peer support in addition to employee-staffed helpdesks and after-sales } \\
\text { services. }\end{array}$ \\
\hline & & $\begin{array}{l}\text { Leisure (Goldmsith and Horrowitz 2006; } \\
\text { McGraw et al. 2015) }\end{array}$ & $\begin{array}{l}\text { Marketers may work with influencers who combine a large audience, authority, and } \\
\text { trustworthiness in the product category with an entertaining, interesting, and } \\
\text { inspirational posting style. }\end{array}$ \\
\hline & & $\begin{array}{l}\text { Accidental exposure (Beyens et al. 2016; } \\
\text { Chen and Berger 2016; Goldmsith and } \\
\text { Horrowitz 2006) }\end{array}$ & $\begin{array}{l}\text { Marketers may feature eWOM in their promotional materials, from newsletters to } \\
\text { search engine advertising (e.g., star ratings displayed in Google ads). On social media } \\
\text { platforms, consumers may see when others in their network are seeking } \\
\text { recommendations (e.g., on Facebook). }\end{array}$ \\
\hline & \multirow{3}{*}{ 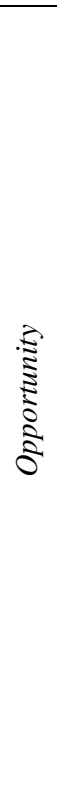 } & $\begin{array}{l}\text { Visibility (Anderson and Magruder 2012; } \\
\text { Clemons et al. 2006; Hansen and Sia 2015; } \\
\text { Lu et al. 2013) }\end{array}$ & $\begin{array}{l}\text { Open platform vs. restricted; sort feature (e.g., by date, similarity-family status, } \\
\text { consumption goals as done by Sephora, Travelocity, HolidayCheck); eWOM display } \\
\text { (show only after a threshold has been reached, e.g., } 4 \text { ratings per restaurant or } 10 \\
\text { reviews per eWOM sender); amount of eWOM displayed per page (e.g., } 5 \text { reviews per } \\
\text { page on Travelocity, } 10 \text { per page on TripAdvisor, Ghose et al. 2012); censorship, } \\
\text { rounding off numerical ratings to the nearest half-star (e.g., on Yelp, an average rating } \\
\text { of } 3.24 \text { displays a 3-star average). } \\
\text { For example, in Hummel (sportswear brand) stores, customers can upload pictures of } \\
\text { themselves or of products via the Instagram hashtag \#hummelsport which is then } \\
\text { displayed on a live screen in store and on Hummel's global website. This way, visual } \\
\text { eWOM is showcased instantaneously across digital channels (Hansen and Sia 2015). }\end{array}$ \\
\hline & & $\begin{array}{l}\text { Network characteristics (strength-of-weak- } \\
\text { ties theory [Granovetter 1973], Dubois et al. } \\
\text { 2016; network size, Peters et al. 2013, } \\
\text { Stephen and Lehmann 2016; network } \\
\text { centrality, Lu et al. 2013, Schulze et al. 2014) }\end{array}$ & $\begin{array}{l}\text { By enhancing eWOM visibility, specifically of eWOM created by friends in the eWOM } \\
\text { receiver's network, marketers can leverage network characteristics and increase } \\
\text { contagion (e.g., "interesting content selected by friends and like-minded people," } \\
\text { Mix.com 2019). }\end{array}$ \\
\hline & & $\begin{array}{l}\text { Contagion characteristics, e.g., depth of } \\
\text { influence, velocity, uniformity of } \\
\text { direction/dominant opinion (Kumar et al. } \\
\text { 2013; Langley et al. 2014) }\end{array}$ & $\begin{array}{l}\text { Exploit the spreadability of marketer-generated communication efforts (e.g., buzz / } \\
\text { guerilla marketing, hashtag hijakcing). Oreo's Dunking in the Dark tweet during the } \\
2013 \text { Superbowl power outage set a new standard for real-time marketing that leverages } \\
\text { intense moments where consumers use relevant fodder to keep a conversation going. } \\
\text { The Oreo tweet was retweeted 15,000 times and reached thousands of consumers. }\end{array}$ \\
\hline & 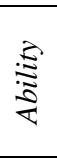 & $\begin{array}{l}\text { Individual characteristics, e.g., age, literacy, } \\
\text { language and Internet proficiency, ability to } \\
\text { join a social network and navigate eWOM } \\
\text { formats (Zhu and Zhang 2010) }\end{array}$ & $\begin{array}{l}\text { Educate consumers on searching through large amounts of eWOM (e.g., how to use the } \\
\text { hashtag to retrieve tweets on a certain topic or how to sort online reviews on a retailer } \\
\text { platform). }\end{array}$ \\
\hline \multirow{4}{*}{ 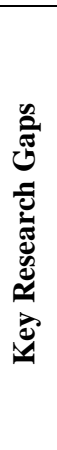 } & & $\begin{array}{l}\text { Investigate maximizing vs. satisficing } \\
\text { eWOM search behaviors }\end{array}$ & $\begin{array}{l}\text { What behaviors do consumers engage in to search for eWOM to reduce risk? What } \\
\text { choices do they make in terms of searching eWOM on one versus multiple platforms? } \\
\text { What is the role of eWOM in light of new risk-reducing options other than eWOM? }\end{array}$ \\
\hline & & Investigate curated and altered eWOM & $\begin{array}{l}\text { What is the effectiveness of cross-channel or omni-channel marketers' curated displays } \\
\text { of eWOM? }\end{array}$ \\
\hline & & $\begin{array}{l}\text { Investigate optimal platform design in social- } \\
\text { risk contexts }\end{array}$ & $\begin{array}{l}\text { How to reduce uncertainty with eWOM for luxury products in which high eWOM } \\
\text { volume may signal accessibility and eWOM content may deteriorate brand image? }\end{array}$ \\
\hline & & $\begin{array}{l}\text { Distinguish eWOM as a proxy vs. as a } \\
\text { market influence }\end{array}$ & $\begin{array}{l}\text { More insight is necessary into how consumers respond to eWOM that they have } \\
\text { actually read, seen, or heard versus eWOM that was merely present on a platform but } \\
\text { never seen. }\end{array}$ \\
\hline
\end{tabular}


Table 4 Stage 3: eWOM evaluation

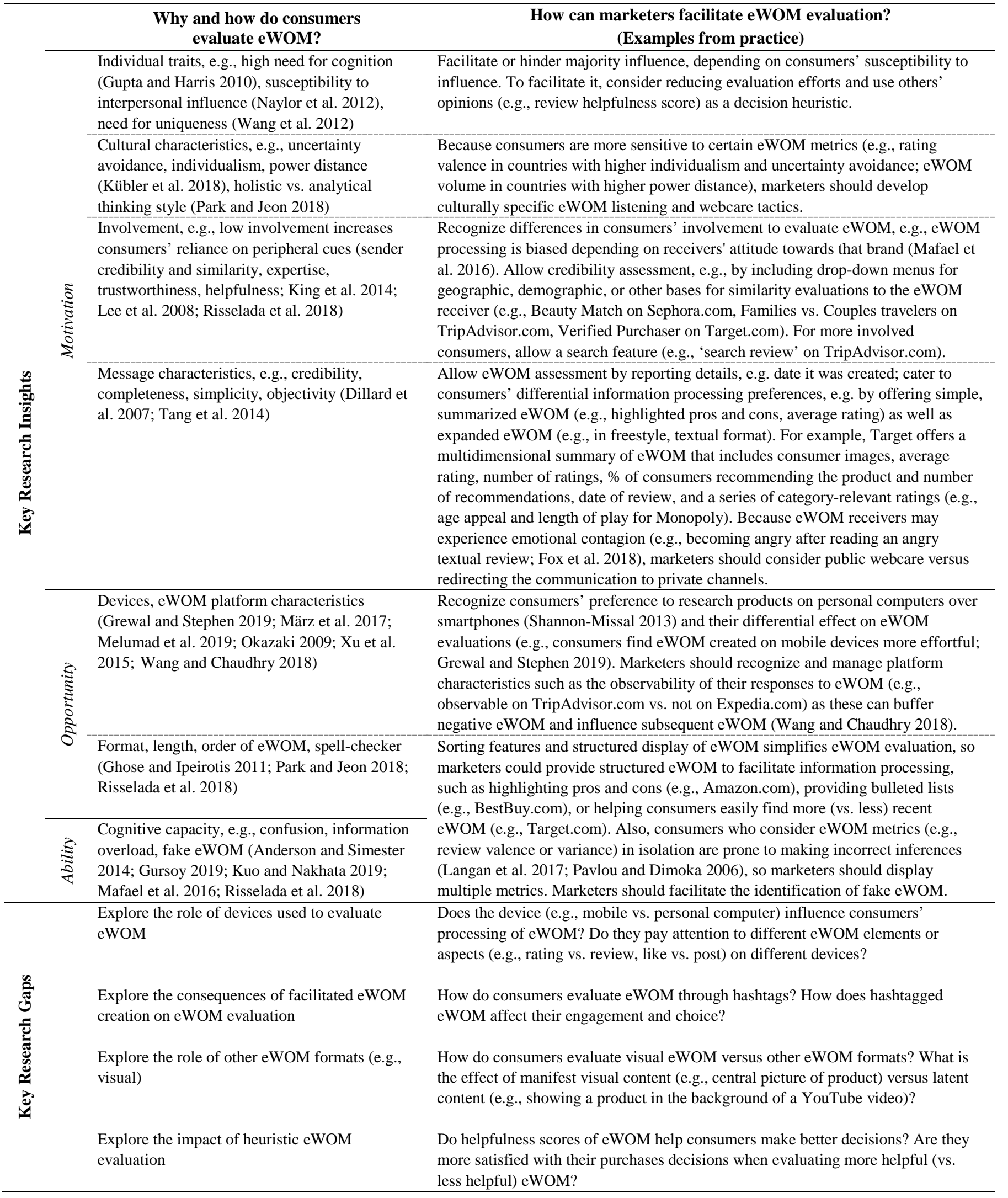


Fig. 1 Organizing framework

CONSUMERS:

MOA

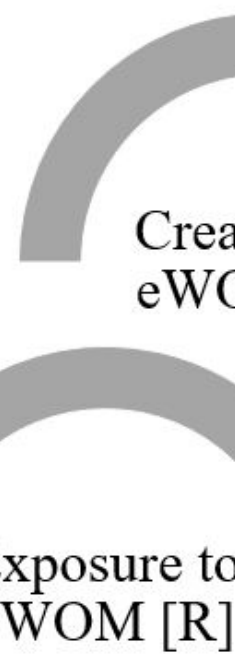

\section{eWOM $[R]$}
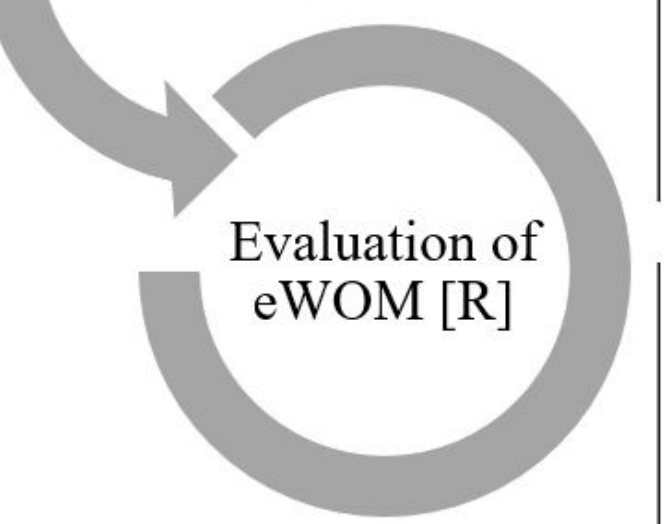

\section{Why and how do consumers create eWOM?}

We Know:

Consumers create original and share existing content; are motivated to create eWOM by altruism, social value from interaction, hedonic benefits, impression management and identity formation (e.g., high-status products), balance restoration, venting, retribtion, economic of eWOM formats; able to create based on product knowledge, tech skill, proficiencies, competencies.

\section{We Need to Know:}

How consumers' abilities impact their eWOM creation.

\section{Why and how do consumers get exposed to eWOM?}

\section{We Know:}

Consumers are motivated to actively seek exposure to eWOM to increase cognition, reduce pre. be accilen exp Therens are exposed to etrom when able to search, navigate eWOM formats (age, language, Internet proficiency).

\section{We Need to Know:}

How consumers search for eWOM to mitigate risk (maximizing vs. satisficing search); how product characteristics shape $\mathrm{eWOM}$ search behavior, how consumers respond to eWOM

hey've read vs. eWOM that was sent but not received.

\section{Why and how do consumers evaluate eWOM?}

\section{We Know:}

mers' motivations to evaluate eWOM (readiness, interest, desire, willingness to process eWOM) are influenced by receiver (susceptibility to interpersonal influence, need for queness, gender, culture, involvement), sender (credibility, similarity), message

characteristics (credibility, similarity, detail, objectivity, helpfulness, simplicity); opportunities determined by context (access device, eWOM format, length, order of presentation); ability to evaluate determined by cognitive resources, skills, Intemet and eWOM proficiency, prior knowledge.

\section{We Need to Know:}

Crices to evaluate eWOM; how consumers evaluate facilitated eWOM (e.g., (ab)used tagging systems), non-textual and non-numerical eWOM; explore consequences of more helpful reviews for both consumers and marketers.
MARKETERS:

\section{LEVERAGING MOA}

\section{How can marketers facilitate eWOM creation?}

We Know:

Marketers can motvate consumers with communication (e.g., nudges, $Q \& A$ ), community uilding (e.g., product co-development), (non)monetary incentives; demotivate consumers from

ffordances, barriers to entry community, prescribing eWOM format (e.g., text length, rating scale); educate consumers on eWOM creation to increase their ability

\section{We Need to Know:}

How incentives impact eWOM senders; how to motivate consumers to create eWOM for unsought products; how effective is marketer-encouraged altruistic eWOM creation; which type of online communities are most valuable.

\section{How can marketers facilitate eWOM exposure?}

We Know:

Marketers can motivate consumers to seek eWOM through traditional marketing mix and direct vitation; increase opportunities for exposure by making eWOM more visible and searchable e.g., online indexing, display, owned media, search engine advertising, sort function, reduce gnal-to-noise ration on own platform); restrict exposure to certain eWOM (e.g., minimum threshold display per page); facilitate access educate consumers on eWOM search to increase their ability.

\section{We Need to Know:}

How effective are marketers' curated and altered displays of eWOM (e.g., in newsletters and ads); how to reduce eWOM uncertainty while preserving brand where consumers perceive high social risk (e.g., optimal online review interface for luxury).

\section{How can marketers facilitate eWOM evaluation?}

We Know:

Weters can motivate consumers to evaluate eWOM through incentives; increase opportunities by shaping platform's technological affordances (include status markers, social cues, spel increase abilities by simplifying ewaluation (e g, thoture eWOMG, allow sorting by helnfulness). Marketers should use advanced methodologies to evaluate eWOM across platforms, respond and provide webcare.

We Need to Know:
How can marketers facilitate eWOM processing through structure, highlights, lists, etc. How will this influence consumers' attitudes toward eWOM and their willingens to use eWOM their decision-makin 


\section{Web Appendix 1}

Publication outlets represented in this systematic review on eWOM

\begin{tabular}{|c|c|}
\hline A: Marketing \& Consumer Research & B: Economics \& Management \\
\hline Publication Outlet & Publication Outlet \\
\hline Academy of Marketing Studies Journal & Academy of Management Journal \\
\hline Advances in Consumer Research & American Economic Review \\
\hline Consumer Tribes & California Management Review \\
\hline Consumption, Markets and Culture & Corporate Communications: An International Journal \\
\hline European Journal of Marketing & European Management Journal \\
\hline Industrial Marketing Management & Harvard Business Review \\
\hline International Journal of Advertising & Journal of Business Ethics \\
\hline International Journal of Marketing Research & Journal of Business Research \\
\hline International Journal of Research in Marketing & MIS Quarterly \\
\hline International Marketing Review & MIS Quarterly Executive \\
\hline Irish Marketing Review & MIT Sloan \\
\hline Journal of Advertising & Management Science \\
\hline Journal of Advertising Research & Strategic Management Journal \\
\hline \multicolumn{2}{|l|}{ Journal of Applied Psychology } \\
\hline Journal of Brand Management & C: IS \& Computer Science \\
\hline Journal of Consumer Behavior & Publication Outlet \\
\hline Journal of Consumer Culture & Computers in Human Behavior \\
\hline Journal of Consumer Marketing & Decision Support Systems \\
\hline Journal of Consumer Policy & Electronic Commerce Research \\
\hline Journal of Consumer Psychology & Electronic Commerce Research and Applications \\
\hline Journal of Consumer Research & Electronic Markets \\
\hline Journal of Direct, Data, and Digital Marketing Practice & Expert Systems with Applications \\
\hline Journal of Interactive Advertising & IEEE Transactions on Knowledge and Data Engineering \\
\hline Journal of Interactive Marketing & Information Systems Research \\
\hline Journal of Macromarketing & International Journal of Electronic Commerce \\
\hline Journal of Marketing & International Journal of Information Management \\
\hline Journal of Marketing Communications & Internet Research \\
\hline Journal of Marketing Management & Journal of Computer-Mediated Communications \\
\hline Journal of Marketing Research & Journal of Management Information Systems \\
\hline \multicolumn{2}{|l|}{ Journal of Marketing Theory and Practice } \\
\hline Journal of Product Innovation Management & D: Tourism \\
\hline Journal of Product and Brand Management & Publication Outlet \\
\hline Journal of Public Policy and Marketing & Annals of Tourism Research \\
\hline Journal of Research in Interactive Marketing & Current Issues in Tourism \\
\hline Journal of Retailing & International Journal of Culture, Tourism, and Hospitality Res. \\
\hline Journal of Retailing and Consumer Services & International Journal of Contemporary Hospitality Man. \\
\hline Journal of Service Research & International Journal of Hospitality Management \\
\hline Journal of Services Marketing & International Journal of Tourism Research \\
\hline Journal of Strategic Marketing & Journal of Hospitality Marketing \& Management \\
\hline Journal of Vacation Marketing & Journal of Hospitality and Tourism Research \\
\hline Journal of the Academy of Marketing Science & Journal of Hospitality and Tourism Technology \\
\hline Marketing Letters & Journal of Travel Research \\
\hline Marketing Science & Journal of Travel and Tourism Marketing \\
\hline Mercati e Competitività & Tourism Management \\
\hline Psychology and Marketing & Tourism Management Perspectives \\
\hline \multicolumn{2}{|l|}{ Research in Consumer Behavior } \\
\hline The Marketing Review & \\
\hline
\end{tabular}

The full list of studies is available in Web Appendix 2. 


\section{Web Appendix 2}

\section{Articles represented in this systematic review on eWOM}

\begin{tabular}{|c|c|c|c|}
\hline Authors & Year & $\begin{array}{c}\text { Title } \\
\end{array}$ & Publication outlet \\
\hline Laughlin and MacDonald & 2010 & $\begin{array}{l}\text { Identifying market mavens online by their social behaviors in } \\
\text { community-generated media }\end{array}$ & $\begin{array}{l}\text { Academy of Marketing Studies } \\
\text { Journal }\end{array}$ \\
\hline Ballantine and Martin & 2005 & Forming Parasocial Relationships in Online Communities & $\begin{array}{l}\text { Advances in Consumer } \\
\text { Research }\end{array}$ \\
\hline Chakravarty, Liu, and Mazumdar & 2009 & $\begin{array}{l}\text { Persuasive Influences of Online Word of Mouth and Professional } \\
\text { Reviews }\end{array}$ & $\begin{array}{l}\text { Advances in Consumer } \\
\text { Research }\end{array}$ \\
\hline Chatterjee & 2001 & Online Reviews: Do Consumers Use Them? & $\begin{array}{l}\text { Advances in Consumer } \\
\text { Research }\end{array}$ \\
\hline Coker & 2012 & $\begin{array}{l}\text { Seeking the Opinions of Others Online: Evidence of Evaluation } \\
\text { Overshoot }\end{array}$ & $\begin{array}{l}\text { Advances in Consumer } \\
\text { Research }\end{array}$ \\
\hline Dambrin and De Valck & 2007 & $\begin{array}{l}\text { Look Who’s Talking! Technology-Supported Impression Formation in } \\
\text { Virtual Communities }\end{array}$ & $\begin{array}{l}\text { Advances in Consumer } \\
\text { Research }\end{array}$ \\
\hline $\begin{array}{l}\text { Domma, Morschett, Schramm-Klein, and } \\
\text { Zentes }\end{array}$ & 2012 & $\begin{array}{l}\text { The Effect of an Integrated Virtual Community on The Evaluation of } \\
\text { an Online Store: Findings from an Internet Experiment }\end{array}$ & $\begin{array}{l}\text { Advances in Consumer } \\
\text { Research }\end{array}$ \\
\hline Faraji-Rad and Dimitriu & 2011 & $\begin{array}{l}\text { The Impact of Negative Online Reviews: When Does Reviewer } \\
\text { Similarity Make a Difference? }\end{array}$ & $\begin{array}{l}\text { Advances in Consumer } \\
\text { Research }\end{array}$ \\
\hline Granitz and Ward & 1996 & Virtual Community: A Sociocognitive Analysis & $\begin{array}{l}\text { Advances in Consumer } \\
\text { Research }\end{array}$ \\
\hline Hoffman and Daugherty & 2013 & $\begin{array}{l}\text { Is a Picture Always Worth a Thousand Words? Attention to Structural } \\
\text { Elements of eWOM for Consumer Brands within Social Media }\end{array}$ & $\begin{array}{l}\text { Advances in Consumer } \\
\text { Research }\end{array}$ \\
\hline Kim, Bickart, and Brunel & 2011 & $\begin{array}{l}\text { Too Much Information? How Expertise Disclosures Affect the } \\
\text { Persuasiveness of Online Consumer Reviews }\end{array}$ & $\begin{array}{l}\text { Advances in Consumer } \\
\text { Research }\end{array}$ \\
\hline Kozinets & 1997 & $\begin{array}{l}\text { "I Want to Believe": A Netnography of The X-Philes' Subculture of } \\
\text { Consumption }\end{array}$ & $\begin{array}{l}\text { Advances in Consumer } \\
\text { Research }\end{array}$ \\
\hline Kozinets & 1998 & $\begin{array}{l}\text { On Netnography: Initial Reflections on Consumer Research } \\
\text { Investigations of Cyberculture }\end{array}$ & $\begin{array}{l}\text { Advances in Consumer } \\
\text { Research }\end{array}$ \\
\hline Kozinets and Handelman & 1998 & $\begin{array}{l}\text { Ensouling Consumption: A Netnographic Exploration of The Meaning } \\
\text { of Boycotting Behavior }\end{array}$ & $\begin{array}{l}\text { Advances in Consumer } \\
\text { Research }\end{array}$ \\
\hline Li and Hung & 2006 & $\begin{array}{l}\text { Netnographic Study of a Community of Beauty Product Enthusiasts in } \\
\text { China: Consumer Reflexivity and Social Concerns }\end{array}$ & $\begin{array}{l}\text { Advances in Consumer } \\
\text { Research }\end{array}$ \\
\hline Liu, Lurie, and Ransbotham & 2013 & The Content and Impact of Mobile Versus Desktop Reviews & $\begin{array}{l}\text { Advances in Consumer } \\
\text { Research }\end{array}$ \\
\hline Madupu and Krishnan & 2008 & $\begin{array}{l}\text { The Relationship between Online Brand Community Participation and } \\
\text { Consciousness of Kind, Moral Responsibility, and Shared Rituals and } \\
\text { Traditions }\end{array}$ & $\begin{array}{l}\text { Advances in Consumer } \\
\text { Research }\end{array}$ \\
\hline Mochon and Schwartz & 2014 & The Individual Dynamics of Online Reviews & $\begin{array}{l}\text { Advances in Consumer } \\
\text { Research }\end{array}$ \\
\hline Oberhofer, Füller, and Hofmann & 2014 & $\begin{array}{l}\text { Tryvertising - What Makes Consumers Share Product Innovations with } \\
\text { Others? }\end{array}$ & $\begin{array}{l}\text { Advances in Consumer } \\
\text { Research }\end{array}$ \\
\hline Okleshen and Grossbart & 1998 & Usenet Groups, Virtual Community and Consumer Behaviors & $\begin{array}{l}\text { Advances in Consumer } \\
\text { Research }\end{array}$ \\
\hline Park and Park & 2008 & $\begin{array}{l}\text { The Multiple Source Effect of Online Consumer Reviews on Brand } \\
\text { Evaluations: Test of the Risk Diversification Hypothesis }\end{array}$ & $\begin{array}{l}\text { Advances in Consumer } \\
\text { Research }\end{array}$ \\
\hline Park, Yoon, and Lee & 2009 & $\begin{array}{l}\text { The Effect of Gender and Product Categories on Consumer Online } \\
\text { Information Search }\end{array}$ & $\begin{array}{l}\text { Advances in Consumer } \\
\text { Research }\end{array}$ \\
\hline Schau and Muniz & 2002 & $\begin{array}{l}\text { Brand Communities and Personal Identities: Negotiations in } \\
\text { Cyberspace }\end{array}$ & $\begin{array}{l}\text { Advances in Consumer } \\
\text { Research }\end{array}$ \\
\hline Schlosser & 2005 & $\begin{array}{l}\text { Source Perceptions and the Persuasiveness of Internet Word-of-Mouth } \\
\text { Communication }\end{array}$ & $\begin{array}{l}\text { Advances in Consumer } \\
\text { Research }\end{array}$ \\
\hline Schneider and Kozinets & 2011 & Beyond Enemy Lines: Sociality in Consumer Activism & $\begin{array}{l}\text { Advances in Consumer } \\
\text { Research }\end{array}$ \\
\hline Schwob & 2010 & $\begin{array}{l}\text { For a Deeper Understanding of the Sociality that Emanates from } \\
\text { Virtual Communities of Consumption }\end{array}$ & $\begin{array}{l}\text { Advances in Consumer } \\
\text { Research }\end{array}$ \\
\hline Sen & 2009 & $\begin{array}{l}\text { Gendered Differences in the Trust of e-Word-of-Mouth from Virtual } \\
\text { Reviewers }\end{array}$ & $\begin{array}{l}\text { Advances in Consumer } \\
\text { Research }\end{array}$ \\
\hline Sen & 2012 & $\begin{array}{l}\text { Trust of the Virtual eWOM Reviewer and the Role of Gendered Self- } \\
\text { Construal }\end{array}$ & $\begin{array}{l}\text { Advances in Consumer } \\
\text { Research }\end{array}$ \\
\hline Siddiqui, Turley, and Rifai & 2008 & $\begin{array}{l}\text { Cries from the Goblin Market: Consumer Narratives in the } \\
\text { Marketplace }\end{array}$ & $\begin{array}{l}\text { Advances in Consumer } \\
\text { Research }\end{array}$ \\
\hline Sussan, Gould, and Weisfeld-Spolter & 2006 & $\begin{array}{l}\text { Location, Location, Location: The Relative Roles of Virtual Location, } \\
\text { Online Word-of-Mouth (eWOM) and Advertising in the New-Product } \\
\text { Adoption Process }\end{array}$ & $\begin{array}{l}\text { Advances in Consumer } \\
\text { Research }\end{array}$ \\
\hline Thompson and Ward & 2008 & $\begin{array}{l}\text { The Evolution of New Product Rumors in Online Consumer } \\
\text { Communities: Social Identity or Social Impact? }\end{array}$ & $\begin{array}{l}\text { Advances in Consumer } \\
\text { Research }\end{array}$ \\
\hline Willemsen, Neijens, and Bronner & 2001 & $\begin{array}{l}\text { The Effects of Expertise Claims and Expertise Warrants on Attitude } \\
\text { towards Online Product Reviews }\end{array}$ & $\begin{array}{l}\text { Advances in Consumer } \\
\text { Research }\end{array}$ \\
\hline Yin, Bond, and Zhang & 2012 & $\begin{array}{l}\text { Are Bad Reviews Stronger than Good? Asymmetric Negativity Biases } \\
\text { in the Formation of Online Consumer Trust }\end{array}$ & $\begin{array}{l}\text { Advances in Consumer } \\
\text { Research }\end{array}$ \\
\hline De Valck & 2007 & The war of the eTribes: online conflicts and communal consumption & Consumer Tribes \\
\hline Pace, Fratocchi, and Cocciola & 2007 & $\begin{array}{l}\text { Internationalization of a craft enterprise through a virtual tribe: 'Le } \\
\text { Nuvole' and the pipe-smoker tribe }\end{array}$ & Consumer Tribes \\
\hline Bean, Khorramian, and O’Donnell & 2018 & Kinfolk magazine: Anchoring a taste regime & $\begin{array}{l}\text { Consumption, Markets and } \\
\text { Culture }\end{array}$ \\
\hline
\end{tabular}




\begin{tabular}{|c|c|c|c|}
\hline Bengtsson, Ostberg, and Kjeldgaard & 2005 & $\begin{array}{l}\text { Prisoners in Paradise: Subcultural Resistance to the Marketization of } \\
\text { Tattooing }\end{array}$ & $\begin{array}{l}\text { Consumption, Markets and } \\
\text { Culture }\end{array}$ \\
\hline Holak & 2014 & $\begin{array}{l}\text { From Brighton beach to blogs: exploring food-related nostalgia in the } \\
\text { Russian diaspora }\end{array}$ & $\begin{array}{l}\text { Consumption, Markets and } \\
\text { Culture }\end{array}$ \\
\hline Hollenbeck and Zinkhan & 2010 & $\begin{array}{l}\text { Anti-brand communities, negotiation of brand meaning, and the } \\
\text { learning process: The case of Wal-Mart }\end{array}$ & $\begin{array}{l}\text { Consumption, Markets and } \\
\text { Culture }\end{array}$ \\
\hline Perfetto and Dholakia & 2010 & Exploring the cultural contradictions of medical tourism & $\begin{array}{l}\text { Consumption, Markets and } \\
\text { Culture }\end{array}$ \\
\hline $\begin{array}{l}\text { Abrantes, Seabra, Lages, and } \\
\text { Jayawardhena }\end{array}$ & 2013 & $\begin{array}{l}\text { Drivers of in-group and out-of-group electronic word-of-mouth } \\
\text { (eWOM) }\end{array}$ & European Journal of Marketing \\
\hline Ahrens, Coyle, and Strahilevitz & 2013 & $\begin{array}{l}\text { Electronic word of mouth: The effects of incentives on e-referrals by } \\
\text { senders and receivers }\end{array}$ & European Journal of Marketing \\
\hline Barrot, Becker, and Meyners & 2013 & Impact of service pricing on referral behaviour & European Journal of Marketing \\
\hline Campbell, Ferraro, and Sands & 2014 & Segmenting consumer reactions to social network marketing & European Journal of Marketing \\
\hline Chen and Huang & 2013 & An investigation into online reviewers' behavior & European Journal of Marketing \\
\hline Chiu, Pant, Hsieh, Lee, Hsioa, and Roan & 2014 & $\begin{array}{l}\text { Snowball to avalanche: Understanding the different predictors of the } \\
\text { intention to propagate online marketing messages }\end{array}$ & European Journal of Marketing \\
\hline $\begin{array}{l}\text { Christodoulides, Michaelidou, and } \\
\text { Argyriou }\end{array}$ & 2012 & Cross-national differences in e-WOM influence & European Journal of Marketing \\
\hline Colliander and Wien & 2013 & $\begin{array}{l}\text { Trash talk rebuffed: consumers' defense of companies criticized in } \\
\text { online communities }\end{array}$ & European Journal of Marketing \\
\hline Cova and Pace & 2006 & $\begin{array}{l}\text { Brand community of convenience products: new forms of customer } \\
\text { empowerment - the case "my Nutella The Community" }\end{array}$ & European Journal of Marketing \\
\hline $\begin{array}{l}\text { Farace, Van Laer, De Ruyter, and } \\
\text { Wetzels }\end{array}$ & 2017 & $\begin{array}{l}\text { Assessing the effect of narrative transportation, portrayed action, and } \\
\text { photographic style on the likelihood to comment on posted selfies }\end{array}$ & European Journal of Marketing \\
\hline Fox, Deitz, Royne, and Fox & 2018 & $\begin{array}{l}\text { The face of contagion: consumer response to service failure depiction } \\
\text { in online reviews }\end{array}$ & European Journal of Marketing \\
\hline Huang, Cai, Tsang, and Zhou & 2011 & Making your online voice loud: The critical role of WOM information & European Journal of Marketing \\
\hline Kerr, Mortimer, Dickinson, and Waller & 2012 & $\begin{array}{l}\text { Buy, boycott or blog: Exploring online consumer power to share, } \\
\text { discuss and distribute controversial advertising messages }\end{array}$ & European Journal of Marketing \\
\hline Khan and Vong & 2014 & Virality over YouTube: An empirical analysis & European Journal of Marketing \\
\hline Koo & 2015 & $\begin{array}{l}\text { The strength of no tie relationship in an online recommendation: } \\
\text { Focused on interactional effects of valence, tie strength, and type of } \\
\text { service }\end{array}$ & European Journal of Marketing \\
\hline Lopez and Sicilia & 2013 & $\begin{array}{l}\text { How WOM marketing contributes to new product adoption: Testing } \\
\text { competitive communication strategies }\end{array}$ & European Journal of Marketing \\
\hline $\begin{array}{l}\text { Marder, Marchant, Archer-Brown, and } \\
\text { Colliander }\end{array}$ & 2018 & Conspicuous political brand interactions on social network sites & European Journal of Marketing \\
\hline Moon, Park, and Kim & 2014 & The impact of text product reviews on sales & European Journal of Marketing \\
\hline Presi, Saridakis, and Hartmans & 2014 & User-generated content behaviour of the dissatisfied service customer & European Journal of Marketing \\
\hline Qiu and Leszcyc & 2016 & Send-for-review decisions, brand equity, and pricing & European Journal of Marketing \\
\hline Qu, Wang, Wang, and Zhang & 2013 & $\begin{array}{l}\text { Implications of online social activities for e-tailers' business } \\
\text { performance }\end{array}$ & European Journal of Marketing \\
\hline Risselada, De Vries, and Verstappen & 2018 & $\begin{array}{l}\text { The impact of social influence on the perceived helpfulness of online } \\
\text { consumer reviews }\end{array}$ & European Journal of Marketing \\
\hline Rogers, Daunt, Morga, and Beynon & 2017 & $\begin{array}{l}\text { Examining the existence of double jeopardy and negative double } \\
\text { jeopardy within Twitter }\end{array}$ & European Journal of Marketing \\
\hline Shen and Luan & 2018 & $\begin{array}{l}\text { Influence of aggregated ratings on purchase decisions: an event-related } \\
\text { potential study }\end{array}$ & European Journal of Marketing \\
\hline Tsang and Prendergast & 2009 & $\begin{array}{l}\text { Is a "star" worth a thousand words? The interplay between product- } \\
\text { review texts and rating valences }\end{array}$ & European Journal of Marketing \\
\hline Wallace, Buil, and Chernatony & 2017 & $\begin{array}{l}\text { Consumers' self-congruence with a "Liked” brand Cognitive network } \\
\text { influence and brand outcomes }\end{array}$ & European Journal of Marketing \\
\hline Yang, Kim, Amblee, and Jeong & 2010 & $\begin{array}{l}\text { The heterogeneous effect of WOM on product sales: why the effect of } \\
\text { WOM valence is mixed? }\end{array}$ & European Journal of Marketing \\
\hline Zhang, Ma, and Cartwright & 2013 & The Impact of Online User Reviews on Cameras Sales & European Journal of Marketing \\
\hline Bruhn, Schnebelen, and Schäfer & 2013 & $\begin{array}{l}\text { Antecedents and consequences of the quality of e-customer-to- } \\
\text { customer interactions in B2B brand communities }\end{array}$ & $\begin{array}{l}\text { Industrial Marketing } \\
\text { Management }\end{array}$ \\
\hline Chatterjee & 2011 & $\begin{array}{l}\text { Drivers of new product recommending and referral behaviour on social } \\
\text { network sites }\end{array}$ & $\begin{array}{l}\text { International Journal of } \\
\text { Advertising }\end{array}$ \\
\hline Chu and Kim & 2011 & $\begin{array}{l}\text { Determinants of consumer engagement in electronic word-of-mouth } \\
\text { (eWOM) in social networking sites }\end{array}$ & $\begin{array}{l}\text { International Journal of } \\
\text { Advertising }\end{array}$ \\
\hline Chu and Kim & 2018 & $\begin{array}{l}\text { The current state of knowledge on electronic word-of-mouth in } \\
\text { advertising research }\end{array}$ & $\begin{array}{l}\text { International Journal of } \\
\text { Advertising }\end{array}$ \\
\hline Chu, Lien, and Cao & 2019 & $\begin{array}{l}\text { Electronic word-of-mouth (eWOM) on WeChat: } \\
\text { examining the influence of sense of belonging, } \\
\text { need for self-enhancement, and consumer } \\
\text { engagement on Chinese travellers' eWOM }\end{array}$ & $\begin{array}{l}\text { International Journal of } \\
\text { Advertising }\end{array}$ \\
\hline Kim, Cheong, and Kim & 2015 & $\begin{array}{l}\text { User-generated product reviews on the internet: the drivers and } \\
\text { outcomes of the perceived usefulness of product reviews }\end{array}$ & $\begin{array}{l}\text { International Journal of } \\
\text { Advertising }\end{array}$ \\
\hline Kwon, Kim, Sung, and Yoo & 2014 & $\begin{array}{l}\text { Brand followers: Consumer motivation and attitude towards brand } \\
\text { communications on Twitter }\end{array}$ & $\begin{array}{l}\text { International Journal of } \\
\text { Advertising }\end{array}$ \\
\hline Lee and Youn & 2009 & $\begin{array}{l}\text { Electronic word of mouth (eWOM): How eWOM platforms influence } \\
\text { consumer product judgement }\end{array}$ & $\begin{array}{l}\text { International Journal of } \\
\text { Advertising }\end{array}$ \\
\hline Levy and Gvili & 2019 & $\begin{array}{l}\text { Online shopper engagement in price negotiation: the roles of culture, } \\
\text { involvement and eWOM }\end{array}$ & $\begin{array}{l}\text { International Journal of } \\
\text { Advertising }\end{array}$ \\
\hline Okazaki & 2009 & $\begin{array}{l}\text { Social influence model and electronic word of mouth: PC versus } \\
\text { mobile internet }\end{array}$ & $\begin{array}{l}\text { International Journal of } \\
\text { Advertising }\end{array}$ \\
\hline Phillips, Miller, and McQuarrie & 2014 & Dreaming out loud on Pinterest: New forms of indirect persuasion & $\begin{array}{l}\text { International Journal of } \\
\text { Advertising }\end{array}$ \\
\hline
\end{tabular}




\begin{tabular}{|c|c|c|c|}
\hline Prendergast, Ko, and Yuen & 2010 & Online word of mouth and consumer purchase intentions & $\begin{array}{l}\text { International Journal of } \\
\text { Advertising }\end{array}$ \\
\hline $\begin{array}{l}\text { Steyn, Ewing, Heerden, Pitt, and } \\
\text { Windisch }\end{array}$ & 2011 & $\begin{array}{l}\text { From whence it came understanding source effects in consumer- } \\
\text { generated advertising }\end{array}$ & $\begin{array}{l}\text { International Journal of } \\
\text { Advertising }\end{array}$ \\
\hline Strutton, Taylor, and Thompson & 2011 & $\begin{array}{l}\text { Investigating generational differences in e-WOM behaviours: For } \\
\text { advertising purposes, does } \mathrm{X}=\mathrm{Y} \text { ? }\end{array}$ & $\begin{array}{l}\text { International Journal of } \\
\text { Advertising }\end{array}$ \\
\hline Breazeale & 2009 & $\begin{array}{l}\text { Word of Mouse - An Assessment of Electronic Word-of-Mouth } \\
\text { Research }\end{array}$ & $\begin{array}{l}\text { International Journal of } \\
\text { Marketing Research }\end{array}$ \\
\hline Decker and Trusov & 2010 & $\begin{array}{l}\text { Estimating aggregate consumer preferences from online product } \\
\text { reviews }\end{array}$ & $\begin{array}{l}\text { International Journal of } \\
\text { Research in Marketing }\end{array}$ \\
\hline Dhar and Weinberg & 2016 & $\begin{array}{l}\text { Measurement of interactions in non-linear marketing models: The } \\
\text { effect of critics' ratings and consumer sentiment on movie demand }\end{array}$ & $\begin{array}{l}\text { International Journal of } \\
\text { Research in Marketing }\end{array}$ \\
\hline Dholakia, Bagozzi, and Pearo & 2004 & $\begin{array}{l}\text { A social influence model of consumer participation in network- and } \\
\text { small-group-based virtual communities }\end{array}$ & $\begin{array}{l}\text { International Journal of } \\
\text { Research in Marketing }\end{array}$ \\
\hline Eelen, Özturan, and Verlegh & 2017 & $\begin{array}{l}\text { The differential impact of brand loyalty on traditional and online word } \\
\text { of mouth: The moderating roles of self-brand connection and the desire } \\
\text { to help the brand }\end{array}$ & $\begin{array}{l}\text { International Journal of } \\
\text { Research in Marketing }\end{array}$ \\
\hline Heimbach and Hinz & 2016 & The impact of content sentiment and emotionality on content virality & $\begin{array}{l}\text { International Journal of } \\
\text { Research in Marketing }\end{array}$ \\
\hline Hervas-Drane & 2015 & $\begin{array}{l}\text { Recommended for you: The effect of word of mouth on sales } \\
\text { concentration }\end{array}$ & $\begin{array}{l}\text { International Journal of } \\
\text { Research in Marketing }\end{array}$ \\
\hline Hollenbeck and Kaikati & 2012 & $\begin{array}{l}\text { Consumers' use of brands to reflect their actual and ideal selves on } \\
\text { Facebook }\end{array}$ & $\begin{array}{l}\text { International Journal of } \\
\text { Research in Marketing }\end{array}$ \\
\hline Hsu and Lawrence & 2016 & $\begin{array}{l}\text { The role of social media and brand equity during a product recall } \\
\text { crisis: A shareholder value perspective }\end{array}$ & $\begin{array}{l}\text { International Journal of } \\
\text { Research in Marketing }\end{array}$ \\
\hline Kannan and $\mathrm{Li}$ & 2017 & Digital marketing: A framework, review and research agenda & $\begin{array}{l}\text { International Journal of } \\
\text { Research in Marketing }\end{array}$ \\
\hline Karniouchina & 2011 & $\begin{array}{l}\text { Impact of star and movie buzz on motion picture distribution and box } \\
\text { office revenue }\end{array}$ & $\begin{array}{l}\text { International Journal of } \\
\text { Research in Marketing }\end{array}$ \\
\hline Kostyra, Reiner, Natter, and Klapper & 2015 & $\begin{array}{l}\text { Decomposing the Effects of Online Customer Reviews on Brand, } \\
\text { Price, and Product Attributes }\end{array}$ & $\begin{array}{l}\text { International Journal of } \\
\text { Research in Marketing }\end{array}$ \\
\hline Kostyra, Reiner, Natter, and Klapper & 2016 & $\begin{array}{l}\text { Decomposing the effects of online customer reviews on brand, price, } \\
\text { and product attributes }\end{array}$ & $\begin{array}{l}\text { International Journal of } \\
\text { Research in Marketing }\end{array}$ \\
\hline Kwortnik and Ross & 2007 & The role of positive emotions in experiential decisions & $\begin{array}{l}\text { International Journal of } \\
\text { Research in Marketing }\end{array}$ \\
\hline Langan, Besharat, and Varki & 2017 & $\begin{array}{l}\text { The effect of review valence and variance on product evaluations: An } \\
\text { examination of intrinsic and extrinsic cues }\end{array}$ & $\begin{array}{l}\text { International Journal of } \\
\text { Research in Marketing }\end{array}$ \\
\hline $\begin{array}{l}\text { Legoux, Larocque, Laporte, Belmati, and } \\
\text { Boquet }\end{array}$ & 2015 & $\begin{array}{l}\text { The effect of critical reviews on exhibitors' decisions: Do reviews } \\
\text { affect the survival of a movie on screen? }\end{array}$ & $\begin{array}{l}\text { International Journal of } \\
\text { Research in Marketing }\end{array}$ \\
\hline Marchand & 2015 & $\begin{array}{l}\text { The power of an installed base to combat lifecycle decline: The case of } \\
\text { video games }\end{array}$ & $\begin{array}{l}\text { International Journal of } \\
\text { Research in Marketing }\end{array}$ \\
\hline Marchand, Hennig-Thurau, and Wiertz & 2017 & $\begin{array}{l}\text { Not all digital word of mouth is created equal: Understanding the } \\
\text { respective impact of consumer reviews and microblogs on new product } \\
\text { success }\end{array}$ & $\begin{array}{l}\text { International Journal of } \\
\text { Research in Marketing }\end{array}$ \\
\hline $\begin{array}{l}\text { Moldovan, Goldenberg, and } \\
\text { Chattopadhyay }\end{array}$ & 2011 & $\begin{array}{l}\text { The different roles of product originality and usefulness in generating } \\
\text { word-of-mouth }\end{array}$ & $\begin{array}{l}\text { International Journal of } \\
\text { Research in Marketing }\end{array}$ \\
\hline Moon and Kamakura & 2017 & $\begin{array}{l}\text { A picture is worth a thousand words: Translating product reviews into } \\
\text { a product positioning map }\end{array}$ & $\begin{array}{l}\text { International Journal of } \\
\text { Research in Marketing }\end{array}$ \\
\hline Mukhopadhyay and Chung & 2016 & Preference instability, consumption and online rating behavior & $\begin{array}{l}\text { International Journal of } \\
\text { Research in Marketing }\end{array}$ \\
\hline Nejad, Amini, and Sherrell & 2015 & $\begin{array}{l}\text { The profit impact of revenue heterogeneity and assortativity in the } \\
\text { presence of negative word-of-mouth }\end{array}$ & $\begin{array}{l}\text { International Journal of } \\
\text { Research in Marketing }\end{array}$ \\
\hline Onishi and Manchanda & 2012 & Marketing Activity, Blogging and Sales & $\begin{array}{l}\text { International Journal of } \\
\text { Research in Marketing }\end{array}$ \\
\hline Pauwels, Akeshirli, and Lackman & 2016 & $\begin{array}{l}\text { Like the ad or the brand? Marketing stimulates different electronic } \\
\text { word-of-mouth content to drive online and offline performance }\end{array}$ & $\begin{array}{l}\text { International Journal of } \\
\text { Research in Marketing }\end{array}$ \\
\hline Peluso, Bonezzi, Angelis, and Rucker & 2016 & Compensatory word of mouth: Advice as a device to restore control & $\begin{array}{l}\text { International Journal of } \\
\text { Research in Marketing }\end{array}$ \\
\hline Relling, Schnittka, Sattler, and Johnen & 2016 & $\begin{array}{l}\text { Each can help or hurt: Negative and positive word of mouth in social } \\
\text { network brand communities }\end{array}$ & $\begin{array}{l}\text { International Journal of } \\
\text { Research in Marketing }\end{array}$ \\
\hline Saboo, Kumar, and Ramani & 2015 & Evaluating the impact of social media activities on human brand sales & $\begin{array}{l}\text { International Journal of } \\
\text { Research in Marketing }\end{array}$ \\
\hline Stephen and Lehmann & 2016 & $\begin{array}{l}\text { How word-of-mouth transmission encouragement affects consumers' } \\
\text { transmission decisions, receiver selection, and diffusion speed }\end{array}$ & $\begin{array}{l}\text { International Journal of } \\
\text { Research in Marketing }\end{array}$ \\
\hline Van Lear and De Ruyter & 2010 & $\begin{array}{l}\text { In stories we trust: How narrative apologies provide cover for } \\
\text { competitive vulnerability after integrity-violating blog posts }\end{array}$ & $\begin{array}{l}\text { International Journal of } \\
\text { Research in Marketing }\end{array}$ \\
\hline Keh, Ji, Wang, Sy-Changco, and Singh & 2015 & $\begin{array}{l}\text { Online movie ratings: a cross-cultural, emerging Asian markets } \\
\text { perspective }\end{array}$ & International Marketing Review \\
\hline Park and Jeon & 2018 & $\begin{array}{l}\text { The impact of mixed eWOM sequence on brand attitude change: cross- } \\
\text { cultural differences }\end{array}$ & International Marketing Review \\
\hline O'Brien & 2011 & The emergence of the social media empowered consumer & Irish Marketing Review \\
\hline Campbell, Pitt, Parent, and Berthon & 2011 & Understanding consumer conversations around ads in a Web 2.0 world & Journal of Advertising \\
\hline Fernando, Suganthi, and Sivakumaran & 2014 & $\begin{array}{l}\text { If You Blog, Will They Follow? Using Online Media to Set the } \\
\text { Agenda for Consumer Concerns on “Greenwashed” Environmental } \\
\text { Claims }\end{array}$ & Journal of Advertising \\
\hline Hung, Li, and Tse & 2011 & $\begin{array}{l}\text { Interpersonal trust and platform credibility in a Chinese multibrand } \\
\text { online community: Effects on Brand Variety Seeking and Time Spent }\end{array}$ & Journal of Advertising \\
\hline Kareklas, Muehling, and Weber & 2015 & $\begin{array}{l}\text { Reexamining Health Messages in the Digital Age: A Fresh Look at } \\
\text { Source Credibility Effects }\end{array}$ & Journal of Advertising \\
\hline Lawrence, Fournier, and Brunel & 2013 & $\begin{array}{l}\text { When Companies Don't Make the Ad: A Multimethod Inquiry into the } \\
\text { Differential Effectiveness of Consumer-Generated Advertising }\end{array}$ & Journal of Advertising \\
\hline
\end{tabular}




\begin{tabular}{|c|c|c|c|}
\hline Minton, Lee, Orth, Kim, and Kahle & 2012 & $\begin{array}{l}\text { Sustainable Marketing and Social Media: A Cross-Country Analysis of } \\
\text { Motives for Sustainable Behaviors }\end{array}$ & Journal of Advertising \\
\hline Muniz and Schau & 2007 & Vigilante Marketing and Consumer-Created Communications & Journal of Advertising \\
\hline $\begin{array}{l}\text { San Jose-Cabezudo and Camarero- } \\
\text { Izquierdo }\end{array}$ & 2012 & Determinants of Opening-Forwarding E-mail Messages & Journal of Advertising \\
\hline Brettel, Reich, Gavilanes, and Flatten & 2015 & $\begin{array}{l}\text { What Drives Advertising Success on Facebook? An Advertising- } \\
\text { Effectiveness Model Measuring the Effects on Sales Of "Likes" and } \\
\text { Other Social-Network Stimuli }\end{array}$ & Journal of Advertising Research \\
\hline Campbell, Cohen, and Ma & 2014 & $\begin{array}{l}\text { Advertisements Just Aren’t Advertisements Anymore: A New } \\
\text { Typology for Evolving Forms of Online “Advertising” }\end{array}$ & Journal of Advertising Research \\
\hline Campbell, Pitt, Parent, and Berthon & 2011 & $\begin{array}{l}\text { Tracking Back-Talk in Consumer-Generated Advertising: An analysis } \\
\text { of Two Interpretative approaches }\end{array}$ & Journal of Advertising Research \\
\hline Christodoulides, Jevons, and Blackshaw & 2011 & $\begin{array}{l}\text { The Voice of the Consumer Speaks Forcefully in Brand Identity: User- } \\
\text { Generated Content Forces Smart Marketers to listen }\end{array}$ & Journal of Advertising Research \\
\hline Christodoulides, Jevons, and Bonhomme & 2012 & $\begin{array}{l}\text { Memo to Marketers: Quantitative Evidence for Change: How User- } \\
\text { Generated Content Really Affects Brands }\end{array}$ & Journal of Advertising Research \\
\hline Colliander and Dahlen & 2011 & $\begin{array}{l}\text { Following the Fashionable Friend: The Power of Social Media } \\
\text { Weighing Publicity Effectiveness of Blogs versus online Magazines }\end{array}$ & Journal of Advertising Research \\
\hline Corstjens and Umblijs & 2012 & $\begin{array}{l}\text { The Power of Evil the Damage of Negative Social Media Strongly } \\
\text { outweigh Positive Contributions }\end{array}$ & Journal of Advertising Research \\
\hline Craig, Greene, and Versaci & 2015 & $\begin{array}{l}\text { E-Word of Mouth: Early Predictor of Audience Engagement How Pre- } \\
\text { Release “E-WOM" Drives Box-Office Outcomes of Movies }\end{array}$ & Journal of Advertising Research \\
\hline Dickinson-Delaporte and Kerr & 2014 & $\begin{array}{l}\text { Agency-Generated Research of Consumer-Generated Content the } \\
\text { Risks, Best Practices, and Ethics }\end{array}$ & Journal of Advertising Research \\
\hline Fulgoni and Lipsman & 2015 & $\begin{array}{l}\text { Digital Word of Mouth and Its Offline Amplification A Holistic } \\
\text { Approach to Leveraging and Amplifying All Forms of WOM }\end{array}$ & Journal of Advertising Research \\
\hline Graham and Havlena & 2007 & $\begin{array}{l}\text { Finding the "Missing Link": Advertising's Impact on Word of Mouth, } \\
\text { Web Searches, and Site Visits }\end{array}$ & Journal of Advertising Research \\
\hline Harrison & 2013 & $\begin{array}{l}\text { Digging Deeper Down into the Empirical Generalization of Brand } \\
\text { Recall Adding Owned and Earned Media to Paid-Media Touchpoints }\end{array}$ & Journal of Advertising Research \\
\hline Huang, Shen, Lin, and Chang & 2007 & Bloggers' Motivations and Behaviors: A Model & Journal of Advertising Research \\
\hline Hung and $\mathrm{Li}$ & 2007 & $\begin{array}{l}\text { The Influence of eWOM on Virtual Consumer Communities: Social } \\
\text { Capital, Consumer Learning, and Behavioral Outcomes }\end{array}$ & Journal of Advertising Research \\
\hline Hutton and Fosdick & 2011 & $\begin{array}{l}\text { The Globalization of Social Media Consumer Relationships with } \\
\text { Brands Evolve in the Digital Space }\end{array}$ & Journal of Advertising Research \\
\hline Jayanti & 2010 & $\begin{array}{l}\text { A Netnographic Exploration: Listening to Online Consumer } \\
\text { Conversations }\end{array}$ & Journal of Advertising Research \\
\hline Keller & 2007 & $\begin{array}{l}\text { Unleashing the Power of Word of Mouth: Creating Brand Advocacy to } \\
\text { Drive Growth }\end{array}$ & Journal of Advertising Research \\
\hline Keller and Fay & 2012 & Word-of-Mouth Advocacy A New Key to Advertising Effectiveness & Journal of Advertising Research \\
\hline Kozinets & 2006 & Click to Connect: Netnography and Tribal Advertising & Journal of Advertising Research \\
\hline Levy and Gvili & 2015 & $\begin{array}{l}\text { How Credible is E-Word of Mouth Across Digital-Marketing } \\
\text { Channels? The Roles of Social Capital, Information Richness, and } \\
\text { Interactivity }\end{array}$ & Journal of Advertising Research \\
\hline $\mathrm{Li}$ & 2011 & The Interactive Web Toward a new Discipline & Journal of Advertising Research \\
\hline Li and Zhan & 2011 & $\begin{array}{l}\text { Online Persuasion: How the Written Word Drives WoM Evidence } \\
\text { from Consumer-Generated Product Reviews }\end{array}$ & Journal of Advertising Research \\
\hline Lipsman, Mudd, Rich, and Bruich & 2012 & $\begin{array}{l}\text { The Power of "Like": How Brands Reach (and Influence) Fans } \\
\text { Through Social-Media Marketing }\end{array}$ & Journal of Advertising Research \\
\hline Moran, Muzellec, and Nolan & 2014 & $\begin{array}{l}\text { Consumer Moments of Truth in the Digital Context: How "Search" } \\
\text { and "E-Word of Mouth" Can Fuel Consumer Decision Making }\end{array}$ & Journal of Advertising Research \\
\hline Nagy and Midha & 2015 & $\begin{array}{l}\text { The Value of Earned Audiences: How Social Interactions Amplify TV } \\
\text { Impact What Programmers and Advertisers Can Gain from Earned } \\
\text { Social Impressions }\end{array}$ & Journal of Advertising Research \\
\hline Nail & 2007 & $\begin{array}{l}\text { Visibility versus Surprise: Which Drives the Greatest Discussion of } \\
\text { Super Bowl Advertisements? }\end{array}$ & Journal of Advertising Research \\
\hline Nelson-Field, Riebe, and Sharp & 2012 & $\begin{array}{l}\text { What's Not to "Like?" Can a Facebook Fan Base Give a Brand the } \\
\text { Advertising reach it Needs? }\end{array}$ & Journal of Advertising Research \\
\hline $\begin{array}{l}\text { Niederhoffer, Mooth, Wiesenfeld, and } \\
\text { Gordon }\end{array}$ & 2007 & $\begin{array}{l}\text { The Origin and Impact of CPG New-Product Buzz: Emerging Trends } \\
\text { and Implications }\end{array}$ & Journal of Advertising Research \\
\hline Okazaki & 2009 & $\begin{array}{l}\text { The Tactical Use of Mobile Marketing: How Adolescents' Social } \\
\text { Networking Can Best Shape Brand Extensions }\end{array}$ & Journal of Advertising Research \\
\hline $\begin{array}{l}\text { Phelps, Lewis, Mobilio, Perry, and } \\
\text { Raman }\end{array}$ & 2004 & $\begin{array}{l}\text { Viral Marketing or Electronic Word-of-Mouth Advertising: Examining } \\
\text { Consumer Responses and Motivations to Pass Along Email }\end{array}$ & Journal of Advertising Research \\
\hline Rappaport & 2010 & Listening Solutions: A Marketer's Guide to Software and Services & Journal of Advertising Research \\
\hline Riegner & 2007 & $\begin{array}{l}\text { Word of Mouth on the Web: The Impact of Web } 2.0 \text { on Consumer } \\
\text { Purchase Decisions }\end{array}$ & Journal of Advertising Research \\
\hline Shi and Wojnicki & 2014 & $\begin{array}{l}\text { Money Talks... to Online Opinion Leaders What Motivates Opinion } \\
\text { Leaders to Make Social-Network Referrals? }\end{array}$ & Journal of Advertising Research \\
\hline $\begin{array}{l}\text { Siefert, Kothuri, Jacobs, Levine, } \\
\text { Plummer, and Marci }\end{array}$ & 2009 & $\begin{array}{l}\text { Winning the Super "Buzz" Bowl: How Biometrically-Based Emotional } \\
\text { Engagement Correlates with Online Views and Comments for Super } \\
\text { Bowl Advertisements }\end{array}$ & Journal of Advertising Research \\
\hline Spotts, Purvis, and Patnaik & 2014 & $\begin{array}{l}\text { How Digital Conversations Reinforce Super Bowl Advertising the } \\
\text { Power of Earned Media Drives Television Engagement }\end{array}$ & Journal of Advertising Research \\
\hline Thorbjornsen, Ketelaar, and Dahlen & 2015 & $\begin{array}{l}\text { How Do Teaser Advertisements Boost Word of Mouth about New } \\
\text { Products? For Consumers, the Future Is More Exciting Than the } \\
\text { Present }\end{array}$ & Journal of Advertising Research \\
\hline Tran and Strutton & 2013 & $\begin{array}{l}\text { What Factors Affect Consumer Acceptance of In-Game } \\
\text { Advertisements? Click "Like" to Manage Digital Content for Players }\end{array}$ & Journal of Advertising Research \\
\hline $\begin{array}{l}\text { Bagozzi, Bergami, Marzocchi, and } \\
\text { Morandin }\end{array}$ & 2012 & $\begin{array}{l}\text { Customer-Organization Relationships: Development and Test of a } \\
\text { Theory of Extended Identities }\end{array}$ & Journal of Applied Psychology \\
\hline
\end{tabular}




\begin{tabular}{|c|c|c|c|}
\hline Boyd, Clarke, and Spekman & 2014 & $\begin{array}{l}\text { The emergence and impact of consumer brand empowerment in online } \\
\text { social networks: A proposed ontology }\end{array}$ & Journal of Brand Management \\
\hline Cova and Paranque & 2012 & $\begin{array}{l}\text { Value creation versus destruction: The relationship between } \\
\text { consumers, marketers and financiers }\end{array}$ & Journal of Brand Management \\
\hline De Vries and Carlson & 2014 & $\begin{array}{l}\text { Examining the drivers and brand performance implications of } \\
\text { customer engagement with brands in the social media environment }\end{array}$ & Journal of Brand Management \\
\hline Dwyer & 2012 & Inferring brand proximities from user-generated content & Journal of Brand Management \\
\hline Foster, West, and Francescucci & 2011 & Exploring social media user segmentation and online brand profiles & Journal of Brand Management \\
\hline Kucuk & 2010 & Negative Double Jeopardy revisited: A longitudinal analysis & Journal of Brand Management \\
\hline Lee, Lee, Taylor, and Lee & 2011 & $\begin{array}{l}\text { Do online brand communities help build and maintain relationships } \\
\text { with consumers? A network theory approach }\end{array}$ & Journal of Brand Management \\
\hline Siano, Vollero, and Palazzo & 2011 & $\begin{array}{l}\text { Exploring the role of online consumer empowerment in reputation } \\
\text { building: Research questions and hypotheses }\end{array}$ & Journal of Brand Management \\
\hline Wallace, Buil, and Chernatony & 2012 & Facebook 'friendship' and brand advocacy & Journal of Brand Management \\
\hline Wang, Butt, and Wei & 2011 & $\begin{array}{l}\text { My identity is my membership: A longitudinal explanation of online } \\
\text { brand community members' behavioral characteristics }\end{array}$ & Journal of Brand Management \\
\hline Ballantine and Stephenson & 2011 & Help me, I’m fat! Social support in online weight loss networks & Journal of Consumer Behavior \\
\hline Black & 2011 & Sorry not today: Self and temporary consumption denial & Journal of Consumer Behavior \\
\hline Catterall and Maclaran & 2001 & Researching consumers in virtual worlds: A cyberspace odyssey & Journal of Consumer Behavior \\
\hline Chen, Kim, and Lin & 2015 & $\begin{array}{l}\text { The effects of affective and cognitive elaborations from Facebook } \\
\text { posts on consumer attitude formation }\end{array}$ & Journal of Consumer Behavior \\
\hline Cosenza, Solomon, and Kwon & 2015 & $\begin{array}{l}\text { Credibility in the blogosphere: A study of measurement and influence } \\
\text { of wine blogs as an information source }\end{array}$ & Journal of Consumer Behavior \\
\hline Harris and Dennis & 2011 & Engaging customers on Facebook: Challenges for e-retailers & Journal of Consumer Behavior \\
\hline Harvey, Stewart, and Ewing & 2011 & $\begin{array}{l}\text { Forward or delete: What drives peer-to-peer message propagation } \\
\text { across social networks? }\end{array}$ & Journal of Consumer Behavior \\
\hline Heinonen & 2011 & $\begin{array}{l}\text { Consumer activity in social media: Managerial approaches to } \\
\text { consumers' social media behavior }\end{array}$ & Journal of Consumer Behavior \\
\hline Key, Boostrom, Adjei, and Campbell & 2013 & $\begin{array}{l}\text { Watch out: Themes in timepiece communities of counterfeit } \\
\text { consumption }\end{array}$ & Journal of Consumer Behavior \\
\hline Liang and Scammon & 2011 & $\begin{array}{l}\text { E-Word-of-Mouth on health social networking sites: An opportunity } \\
\text { for tailored health communication }\end{array}$ & Journal of Consumer Behavior \\
\hline Lyons and Henderson & 2005 & Opinion leadership in a computer-mediated environment & Journal of Consumer Behavior \\
\hline Meissner, Heinzle, and Decker & 2013 & $\begin{array}{l}\text { Not worth the extra cost? Diluting the differentiation ability of highly } \\
\text { rated products by altering the meaning of rating scale levels }\end{array}$ & Journal of Consumer Behavior \\
\hline Narvanen, Kartastenpaa, and Kuusela & 2013 & $\begin{array}{l}\text { Online lifestyle consumption community dynamics: A practice-based } \\
\text { analysis }\end{array}$ & Journal of Consumer Behavior \\
\hline Pehlivan, Sarican, and Berthon & 2011 & $\begin{array}{l}\text { Mining messages: Exploring consumer response to consumer- vs. } \\
\text { firm-generated ads }\end{array}$ & Journal of Consumer Behavior \\
\hline Racherla, Mandiwalla, and Connolly & 2012 & Factors affecting consumers' trust in online product reviews & Journal of Consumer Behavior \\
\hline Schindler and Bickart & 2012 & $\begin{array}{l}\text { Perceived helpfulness of online consumer reviews: The role of } \\
\text { message content and style }\end{array}$ & Journal of Consumer Behavior \\
\hline Thomas & 2004 & Building the buzz in the hive mind & Journal of Consumer Behavior \\
\hline Ziegele and Weber & 2015 & $\begin{array}{l}\text { Example, please! Comparing the effects of single customer reviews } \\
\text { and aggregate review scores on online shoppers' product evaluations }\end{array}$ & Journal of Consumer Behavior \\
\hline Hardey & 2010 & Consuming Professions User-review websites and health services & Journal of Consumer Culture \\
\hline Hewer and Brownlie & 2013 & $\begin{array}{l}\text { Spaces of hope, enlivenment and entanglement: Explorations in the } \\
\text { spatial logic of celebrity culinary brands }\end{array}$ & Journal of Consumer Culture \\
\hline Pecoraro and Uusitalo & 2014 & $\begin{array}{l}\text { Conflicting values of ethical consumption in diverse worlds - A } \\
\text { cultural approach }\end{array}$ & Journal of Consumer Culture \\
\hline Ahuja, Michels, Walker, and Weissbuch & 2007 & Teen perceptions of disclosure in buzz marketing & Journal of Consumer Marketing \\
\hline Felix & 2012 & $\begin{array}{l}\text { Brand communities for mainstream brands: the example of the } \\
\text { Yamaha R1 brand community }\end{array}$ & Journal of Consumer Marketing \\
\hline Flurry, Swimberghe, and Parker & 2014 & $\begin{array}{l}\text { Examining brand communities among children and adolescents: an } \\
\text { exploratory study }\end{array}$ & Journal of Consumer Marketing \\
\hline Karakaya and Barnes & 2010 & $\begin{array}{l}\text { Impact of online reviews of customer care experience on brand or } \\
\text { company selection }\end{array}$ & Journal of Consumer Marketing \\
\hline Moore & 2011 & Interactive media usage among millennial consumers & Journal of Consumer Marketing \\
\hline Mosteller and Mathwick & 2014 & $\begin{array}{l}\text { Reviewer online engagement: the role of rank, well-being, and market } \\
\text { helping behavior }\end{array}$ & Journal of Consumer Marketing \\
\hline Park and Cho & 2012 & $\begin{array}{l}\text { Social network online communities: information sources for apparel } \\
\text { shopping }\end{array}$ & Journal of Consumer Marketing \\
\hline Patino, Pitta, and Quinones & 2012 & Social media’s emerging importance in market research & Journal of Consumer Marketing \\
\hline Thakur, Summey, and John & 2013 & $\begin{array}{l}\text { A perceptual approach to understanding user-generated media } \\
\text { behavior }\end{array}$ & Journal of Consumer Marketing \\
\hline Malbon & 2013 & Taking Fake Online Consumer Reviews Seriously & Journal of Consumer Policy \\
\hline Riefa & 2008 & $\begin{array}{l}\text { "To Be or Not to Be an Auctioneer?" Some Thoughts on the Legal } \\
\text { Nature of Online "eBay" Auctions and the Protection of Consumers }\end{array}$ & Journal of Consumer Policy \\
\hline Berger & 2014 & $\begin{array}{l}\text { Word of mouth and interpersonal communication: A review and } \\
\text { directions for future research }\end{array}$ & $\begin{array}{l}\text { Journal of Consumer } \\
\text { Psychology }\end{array}$ \\
\hline Buechel and Berger & 2017 & Microblogging and the Value of Undirected Communication & $\begin{array}{l}\text { Journal of Consumer } \\
\text { Psychology }\end{array}$ \\
\hline Chen and Kirmani & 2015 & Posting strategically: The consumer as an online media planner & $\begin{array}{l}\text { Journal of Consumer } \\
\text { Psychology }\end{array}$ \\
\hline Eisingerich, Chun, Liu, Jia, and Bell & 2015 & $\begin{array}{l}\text { Why recommend a brand face-to-face but not on Facebook? How } \\
\text { word-of-mouth on online social sites differs from traditional word-of- } \\
\text { mouth }\end{array}$ & $\begin{array}{l}\text { Journal of Consumer } \\
\text { Psychology }\end{array}$ \\
\hline $\begin{array}{l}\text { Gershoff, Mukherjee, and } \\
\text { Mukhopadhyay }\end{array}$ & 2003 & $\begin{array}{l}\text { Consumer Acceptance of Online Agent Advice: Extremity and } \\
\text { Positivity Effects }\end{array}$ & $\begin{array}{l}\text { Journal of Consumer } \\
\text { Psychology }\end{array}$ \\
\hline He and Bond & 2013 & Word-of-mouth and the forecasting of consumption enjoyment & $\begin{array}{l}\text { Journal of Consumer } \\
\text { Psychology }\end{array}$ \\
\hline
\end{tabular}




\begin{tabular}{|c|c|c|c|}
\hline Huang, Burtch, Hong, and Polman & 2016 & $\begin{array}{l}\text { Effects of multiple psychological distances on construal and consumer } \\
\text { evaluation: A field study of online reviews }\end{array}$ & $\begin{array}{l}\text { Journal of Consumer } \\
\text { Psychology }\end{array}$ \\
\hline Mafael & 2019 & $\begin{array}{l}\text { How Regulatory Orientation and Feelings of Gratitude Shape Online } \\
\text { Review Helpfulness }\end{array}$ & $\begin{array}{l}\text { Journal of Consumer } \\
\text { Psychology }\end{array}$ \\
\hline Packard and Wooten & 2013 & Compensatory knowledge signaling in consumer word-of-mouth & $\begin{array}{l}\text { Journal of Consumer } \\
\text { Psychology }\end{array}$ \\
\hline Schlosser & 2011 & $\begin{array}{l}\text { Can including pros and cons increase the helpfulness and } \\
\text { persuasiveness of online reviews? The interactive effects of ratings and } \\
\text { arguments }\end{array}$ & $\begin{array}{l}\text { Journal of Consumer } \\
\text { Psychology }\end{array}$ \\
\hline Shoham, Moldovan, and Steinhart & 2016 & $\begin{array}{l}\text { Positively useless: irrelevant negative information enhances positive } \\
\text { impressions }\end{array}$ & $\begin{array}{l}\text { Journal of Consumer } \\
\text { Psychology }\end{array}$ \\
\hline Zinkhan, Kwak, Morrison, and Peters & 2003 & Web-Based Chatting: Consumer Communication in Cyberspace & $\begin{array}{l}\text { Journal of Consumer } \\
\text { Psychology }\end{array}$ \\
\hline Arsel and Bean & 2013 & Taste Regimes and Market-Mediated Practice & Journal of Consumer Research \\
\hline Arvidsson and Caliandro & 2016 & Brand Public & Journal of Consumer Research \\
\hline Belk & 2013 & Extended Self in a Digital World & Journal of Consumer Research \\
\hline Berger and Iyengar & 2013 & $\begin{array}{l}\text { Communication Channels and Word of Mouth: How the Medium } \\
\text { Shapes the Message }\end{array}$ & Journal of Consumer Research \\
\hline Chen & 2017 & $\begin{array}{l}\text { Social Acceptance and Word of Mouth: How the Motive to Belong } \\
\text { Leads to Divergent WOM with Strangers and Friends }\end{array}$ & Journal of Consumer Research \\
\hline Chen and Berger & 2016 & How Content Acquisition Method Affects Word of Mouth & Journal of Consumer Research \\
\hline Chen, Duan, and Zhou & 2017 & $\begin{array}{l}\text { The Interplay Between Free Sampling and Word of Mouth in the } \\
\text { Online Software Market }\end{array}$ & Journal of Consumer Research \\
\hline De Langhe, Fernbach, and Lichtenstein & 2015 & $\begin{array}{l}\text { Navigating by the Stars: Investigating the Actual and Perceived } \\
\text { Validity of Online User Ratings }\end{array}$ & Journal of Consumer Research \\
\hline De Langhe, Fernbach, and Lichtenstein & 2016 & Star Wars: Response to Simonson, Winer/ Fader, and Kozinets & Journal of Consumer Research \\
\hline Dolbec and Fischer & 2015 & $\begin{array}{l}\text { Refashioning a Field? Connected Consumers and Institutional } \\
\text { Dynamics in Markets }\end{array}$ & Journal of Consumer Research \\
\hline He and Bond & 2015 & $\begin{array}{l}\text { Why Is the Crowd Divided? Attribution for Dispersion in Online Word } \\
\text { of Mouth }\end{array}$ & Journal of Consumer Research \\
\hline Humphreys and Wang & 2018 & Automated Text Analysis for Consumer Research & Journal of Consumer Research \\
\hline Jayanti and Singh & 2010 & $\begin{array}{l}\text { Pragmatic Learning Theory: An Inquiry-Action Framework for } \\
\text { Distributed Consumer Learning in Online Communities }\end{array}$ & Journal of Consumer Research \\
\hline Kozinets & 2016 & $\begin{array}{l}\text { Amazonian Forests and Trees: Multiplicity and Objectivity in Studies } \\
\text { of Online Consumer-Generated Ratings and Reviews, A Commentary } \\
\text { on de Langhe, Fernbach, and Lichtenstein }\end{array}$ & Journal of Consumer Research \\
\hline Kronrod and Danziger & 2013 & $\begin{array}{l}\text { "Wii Will Rock You!” The Use and Effect of Figurative Language in } \\
\text { Consumer Reviews of Hedonic and Utilitarian Consumption }\end{array}$ & Journal of Consumer Research \\
\hline Kupor and Tormala & 2018 & $\begin{array}{l}\text { When Moderation Fosters Persuasion: The } \\
\text { Persuasive Power of Deviatory Reviews }\end{array}$ & Journal of Consumer Research \\
\hline Mathwick, Wiertz, and De Ruyter & 2008 & Social Capital Production in a Virtual P3 Community & Journal of Consumer Research \\
\hline McGraw, Warren, and Kan & 2015 & Humorous Complaining & Journal of Consumer Research \\
\hline McQuarrie, Miller, and Phillips & 2013 & The Megaphone Effect: Taste and Audience in Fashion Blogging & Journal of Consumer Research \\
\hline Moore & 2012 & $\begin{array}{l}\text { Some Things Are Better Left Unsaid: How Word of Mouth Influences } \\
\text { the Storyteller }\end{array}$ & Journal of Consumer Research \\
\hline Muniz and O'Guinn & 2001 & Brand Community & Journal of Consumer Research \\
\hline Muniz and Schau & 2005 & Religiosity in the Abandoned Apple Newton Brand Community & Journal of Consumer Research \\
\hline Parmentier and Fischer & 2015 & Things Fall Apart: The Dynamics of Brand Audience Dissipation & Journal of Consumer Research \\
\hline Rozenkrants, Wheeler, and Shive & 2017 & $\begin{array}{l}\text { Self-Expression Cues in Product Rating Distributions: When People } \\
\text { Prefer Polarizing Products }\end{array}$ & Journal of Consumer Research \\
\hline Russell and Schau & 2014 & $\begin{array}{l}\text { When Narrative Brands End: The Impact of Narrative Closure and } \\
\text { Consumption Sociality on Loss Accommodation }\end{array}$ & Journal of Consumer Research \\
\hline Scaraboto and Fischer & 2013 & $\begin{array}{l}\text { Frustrated Fatshionistas: An Institutional Theory Perspective on } \\
\text { Consumer Quests for Greater Choice in Mainstream Markets }\end{array}$ & Journal of Consumer Research \\
\hline Schau and Gilly & 2003 & We Are What We Post? Self-Presentation in Personal Web Space & Journal of Consumer Research \\
\hline Schlosser & 2005 & $\begin{array}{l}\text { Posting versus Lurking: Communicating in a Multiple Audience } \\
\text { Context }\end{array}$ & Journal of Consumer Research \\
\hline Simonson & 2016 & $\begin{array}{l}\text { Imperfect Progress: An Objective Quality Assessment of the Role of } \\
\text { User Reviews in Consumer Decision Making, A Commentary on de } \\
\text { Langhe, Fernbach, and Lichtenstein }\end{array}$ & Journal of Consumer Research \\
\hline Thomas, Price, and Schau & 2013 & $\begin{array}{l}\text { When Differences Unite: Resource Dependence in Heterogeneous } \\
\text { Consumption Communities }\end{array}$ & Journal of Consumer Research \\
\hline $\begin{array}{l}\text { Villarroel Ordenes, Ludwig, De Ruyter, } \\
\text { Grewal, and Wetzels }\end{array}$ & 2017 & $\begin{array}{l}\text { Unveiling What Is Written in the Stars: Analyzing Explicit, Implicit, } \\
\text { and Discourse Patterns of Sentiment in Social Media }\end{array}$ & Journal of Consumer Research \\
\hline Ward and Ostrom & 2006 & $\begin{array}{l}\text { Complaining to the Masses: The Role of Protest Framing in Customer- } \\
\text { Created Complaint Web Sites }\end{array}$ & Journal of Consumer Research \\
\hline Di Pietro and Pantano & 2013 & $\begin{array}{l}\text { Social network influences on young tourists: An exploratory analysis } \\
\text { of determinants of the purchasing intention }\end{array}$ & $\begin{array}{l}\text { Journal of Direct, Data, and } \\
\text { Digital Marketing Practice }\end{array}$ \\
\hline Duhan and Singh & 2014 & $\begin{array}{l}\text { Virtual communities' antecedents and marketing dynamism: An } \\
\text { empirical study of tourists visiting Varanasi }\end{array}$ & $\begin{array}{l}\text { Journal of Direct, Data, and } \\
\text { Digital Marketing Practice }\end{array}$ \\
\hline Foux & 2005 & $\begin{array}{l}\text { Customer Communities Herald New Ground Rules for Successful } \\
\text { Marketing }\end{array}$ & $\begin{array}{l}\text { Journal of Direct, Data, and } \\
\text { Digital Marketing Practice }\end{array}$ \\
\hline Rogers, Chapman, and Giosas & 2012 & $\begin{array}{l}\text { Measuring the diffusion of marketing messages across a social } \\
\text { network }\end{array}$ & $\begin{array}{l}\text { Journal of Direct, Data, and } \\
\text { Digital Marketing Practice }\end{array}$ \\
\hline $\begin{array}{l}\text { Vorvoreanu, Boisvenue, Wojtalewicz, } \\
\text { and Dietz }\end{array}$ & 2013 & $\begin{array}{l}\text { Social media marketing analytics: A case study of the public’s } \\
\text { perception of Indianapolis as Super Bowl XLVIII host city }\end{array}$ & $\begin{array}{l}\text { Journal of Direct, Data, and } \\
\text { Digital Marketing Practice }\end{array}$ \\
\hline Zanette, Brito, and Coutinho & 2013 & New influentials: An exploratory study on blogs & $\begin{array}{l}\text { Journal of Direct, Data, and } \\
\text { Digital Marketing Practice }\end{array}$ \\
\hline Bailey & 2005 & Consumer Awareness and Use of Product Review Websites & $\begin{array}{l}\text { Journal of Interactive } \\
\text { Advertising }\end{array}$ \\
\hline
\end{tabular}




\begin{tabular}{|c|c|c|c|}
\hline Carr and Hayes & 2014 & $\begin{array}{l}\text { The Effect of Disclosure of Third-Party Influence on an Opinion } \\
\text { Leader's Credibility and Electronic Word of Mouth in Two-Step Flow }\end{array}$ & $\begin{array}{l}\text { Journal of Interactive } \\
\text { Advertising }\end{array}$ \\
\hline Cheong and Morrison & 2008 & $\begin{array}{l}\text { Consumers' Reliance on Product Information and Recommendations } \\
\text { Found in UGC }\end{array}$ & $\begin{array}{l}\text { Journal of Interactive } \\
\text { Advertising }\end{array}$ \\
\hline Chu and Kamal & 2008 & $\begin{array}{l}\text { The effect of perceived blogger credibility and argument quality on } \\
\text { message elaboration and brand attitudes: An exploratory study }\end{array}$ & $\begin{array}{l}\text { Journal of Interactive } \\
\text { Advertising }\end{array}$ \\
\hline Daugherty, Eastin, and Bright & 2010 & Exploring consumer motivations for creating user-generated content & $\begin{array}{l}\text { Journal of Interactive } \\
\text { Advertising }\end{array}$ \\
\hline Goldsmith and Horowitz & 2006 & Measuring Motivations for Online Opinion Seeking & $\begin{array}{l}\text { Journal of Interactive } \\
\text { Advertising }\end{array}$ \\
\hline Grant, Botha, and Kietzmann & 2015 & $\begin{array}{l}\text { Branded Flash Mobs: Moving Toward a Deeper Understanding of } \\
\text { Consumers' Responses to Video Advertising }\end{array}$ & $\begin{array}{l}\text { Journal of Interactive } \\
\text { Advertising }\end{array}$ \\
\hline Hayes and King & 2014 & $\begin{array}{l}\text { The Social Exchange of Viral Ads: Referral and Coreferral of Ads } \\
\text { Among College Students }\end{array}$ & $\begin{array}{l}\text { Journal of Interactive } \\
\text { Advertising }\end{array}$ \\
\hline Lopez and Sicilia & 2014 & $\begin{array}{l}\text { eWOM as Source of Influence: The Impact of Participation in eWOM } \\
\text { and Perceived Source Trustworthiness on Decision Making }\end{array}$ & $\begin{array}{l}\text { Journal of Interactive } \\
\text { Advertising }\end{array}$ \\
\hline Morrison, Cheong, and McMillan & 2013 & $\begin{array}{l}\text { Posting, Lurking, and Networking: Behaviors and Characteristics of } \\
\text { Consumers in the Context of User-Generated Content }\end{array}$ & $\begin{array}{l}\text { Journal of Interactive } \\
\text { Advertising }\end{array}$ \\
\hline Muk and Chung & 2014 & $\begin{array}{l}\text { Driving Consumers to Become Fans of Brand Pages: A Theoretical } \\
\text { Framework }\end{array}$ & $\begin{array}{l}\text { Journal of Interactive } \\
\text { Advertising }\end{array}$ \\
\hline Porter and Golan & 2006 & $\begin{array}{l}\text { From Subservient Chickens to Brawny Men: A Comparison of Viral } \\
\text { Advertising to Television Advertising }\end{array}$ & $\begin{array}{l}\text { Journal of Interactive } \\
\text { Advertising }\end{array}$ \\
\hline Shan and King & 2015 & $\begin{array}{l}\text { The Effects of Interpersonal Tie Strength and Subjective Norms on } \\
\text { Consumers' Brand-Related eWOM Referral Intentions }\end{array}$ & $\begin{array}{l}\text { Journal of Interactive } \\
\text { Advertising }\end{array}$ \\
\hline Steyer, Garcia-Bardidia, and Quester & 2006 & $\begin{array}{l}\text { Online Discussion Groups as Social Networks: An Empirical } \\
\text { Investigation of Word-of-Mouth on the Internet }\end{array}$ & $\begin{array}{l}\text { Journal of Interactive } \\
\text { Advertising }\end{array}$ \\
\hline Tsai and Men & 2013 & $\begin{array}{l}\text { Motivations and Antecedents of Consumer Engagement With Brand } \\
\text { Pages on Social Networking Sites }\end{array}$ & $\begin{array}{l}\text { Journal of Interactive } \\
\text { Advertising }\end{array}$ \\
\hline Vilpponen, Winter, and Sundqvist & 2006 & $\begin{array}{l}\text { Electronic word-of-mouth in online environments: exploring referral } \\
\text { network structure and adoption behavior }\end{array}$ & $\begin{array}{l}\text { Journal of Interactive } \\
\text { Advertising }\end{array}$ \\
\hline Wang, Zhang, Li, and Zhu & 2010 & $\begin{array}{l}\text { Why do moviegoers go to the theater? The role of prerelease media } \\
\text { publicity and online word of mouth in driving movie going behavior }\end{array}$ & $\begin{array}{l}\text { Journal of Interactive } \\
\text { Advertising }\end{array}$ \\
\hline Xia and Bechwati & 2008 & $\begin{array}{l}\text { Word of Mouse: The Role of Cognitive Personalization in Online } \\
\text { Consumer Reviews }\end{array}$ & $\begin{array}{l}\text { Journal of Interactive } \\
\text { Advertising }\end{array}$ \\
\hline Aletia, Pallant, Tuan, and Van Laer & 2019 & $\begin{array}{l}\text { Tweeting with the Stars: Automated Text Analysis of the Effect of } \\
\text { Celebrity Social Media Communications on Consumer Word of Mouth }\end{array}$ & Journal of Interactive Marketing \\
\hline Balague and De Valck & 2013 & $\begin{array}{l}\text { Using Blogs to Solicit Consumer Feedback: The Role of Directive } \\
\text { Questioning Versus No Questioning }\end{array}$ & Journal of Interactive Marketing \\
\hline Barcelos, Dantas, and Sénécal & 2017 & $\begin{array}{l}\text { Watch Your Tone: How a Brand's Tone of Voice on Social Media } \\
\text { Influences Consumer Responses }\end{array}$ & Journal of Interactive Marketing \\
\hline Beukeboom, Kerkhof, and De Vries & 2015 & $\begin{array}{l}\text { Does a Virtual Like Cause Actual Liking? How Following a Brand's } \\
\text { Facebook Updates Enhances Brand Evaluations and Purchase } \\
\text { Intention }\end{array}$ & Journal of Interactive Marketing \\
\hline Bickart and Schindler & 2001 & Internet Forums as Influential Sources of Consumer Information & Journal of Interactive Marketing \\
\hline Bolton and Saxena-Iyer & 2009 & Interactive Services: A Framework, Synthesis and Research Directions & Journal of Interactive Marketing \\
\hline Brown, Broderick, and Lee & 2007 & $\begin{array}{l}\text { Word of Mouth Communication Within Online Communities: } \\
\text { Conceptualizing the Online Social Network }\end{array}$ & Journal of Interactive Marketing \\
\hline Bruce, Haruvy, and Rao & 2004 & Seller Rating, Price, and Default in Online Auctions & Journal of Interactive Marketing \\
\hline Chakravarty, Liu, and Mazumdar & 2010 & $\begin{array}{l}\text { The Differential Effects of Online Word-of-Mouth and Critics' } \\
\text { Reviews on Pre-release Movie Evaluation }\end{array}$ & Journal of Interactive Marketing \\
\hline Chen, Fay, and Wang & 2011 & $\begin{array}{l}\text { The Role of Marketing in Social Media: How Online Consumer } \\
\text { Reviews Evolve }\end{array}$ & Journal of Interactive Marketing \\
\hline Chiou and Cheng & 2003 & Should a company have message boards on its web sites? & Journal of Interactive Marketing \\
\hline De Vries, Gensler, and Leeflang & 2012 & $\begin{array}{l}\text { Popularity of Brand Posts on Brand Fan Pages: An Investigation of the } \\
\text { Effects of Social Media Marketing }\end{array}$ & Journal of Interactive Marketing \\
\hline Dellarocas, Zhang, and Awad & 2007 & $\begin{array}{l}\text { Exploring the Value of Online Product Reviews in Forecasting Sales: } \\
\text { The Case of Motion Pictures }\end{array}$ & Journal of Interactive Marketing \\
\hline Dhar and Chang & 2009 & $\begin{array}{l}\text { Does Chatter Matter? The Impact of User-Generated Content on Music } \\
\text { Sales }\end{array}$ & Journal of Interactive Marketing \\
\hline Dholakia & 2005 & $\begin{array}{l}\text { The usefulness of bidders' reputation ratings to sellers in online } \\
\text { auctions }\end{array}$ & Journal of Interactive Marketing \\
\hline Dwyer & 2007 & $\begin{array}{l}\text { Measuring the value of electronic word of mouth and its impact in } \\
\text { consumer communities }\end{array}$ & Journal of Interactive Marketing \\
\hline Ertimur and Gilly & 2012 & $\begin{array}{l}\text { So Whaddya Think? Consumers Create Ads and Other Consumers } \\
\text { Critique Them }\end{array}$ & Journal of Interactive Marketing \\
\hline Feng and Papatla & 2011 & Advertising: Stimulant or Suppressant of Online Word of Mouth? & Journal of Interactive Marketing \\
\hline Feng and Papatla & 2012 & $\begin{array}{l}\text { Is Online Word of Mouth Higher for New Models or Redesigns? An } \\
\text { Investigation of the Automobile Industry }\end{array}$ & Journal of Interactive Marketing \\
\hline $\begin{array}{l}\text { Gensler, Volckner, Liu-Thompkins, and } \\
\text { Wiertz }\end{array}$ & 2013 & Managing Brands in the Social Media Environment & Journal of Interactive Marketing \\
\hline Guan and Lam & 2019 & Product Rating Statistics as Consumer Search Aids & Journal of Interactive Marketing \\
\hline Hautz, Fueller, Hutter, and Thuerridl & 2014 & $\begin{array}{l}\text { Let Users Generate Your Video Ads? The Impact of Video Source and } \\
\text { Quality on Consumers' Perceptions and Intended Behaviors }\end{array}$ & Journal of Interactive Marketing \\
\hline Hayes, King, and Ramirez & 2016 & $\begin{array}{l}\text { Brands, Friends, \& Viral Advertising: A Social Exchange Perspective } \\
\text { on the Ad Referral Processes }\end{array}$ & Journal of Interactive Marketing \\
\hline $\begin{array}{l}\text { Hennig-Thurau, Gwinner, Walsh, and } \\
\text { Gremler }\end{array}$ & 2004 & $\begin{array}{l}\text { Electronic word-of-mouth via consumer-opinion platforms: what } \\
\text { motivates consumers to articulate themselves on the internet? }\end{array}$ & Journal of Interactive Marketing \\
\hline Huang, Su, Zhou, and Liu & 2013 & $\begin{array}{l}\text { Attitude Toward the Viral Ad: Expanding Traditional Advertising } \\
\text { Models to Interactive Advertising }\end{array}$ & Journal of Interactive Marketing \\
\hline Jimenez and Mendoza & 2013 & $\begin{array}{l}\text { Too Popular to Ignore: The Influence of Online Reviews on Purchase } \\
\text { Intentions of Search and Experience Products }\end{array}$ & Journal of Interactive Marketing \\
\hline
\end{tabular}




\begin{tabular}{|c|c|c|c|}
\hline Johnson and Lowe & 2015 & $\begin{array}{l}\text { Emotional Support, Perceived Corporate Ownership and Skepticism } \\
\text { toward Out-groups in Virtual Communities }\end{array}$ & Journal of Interactive Marketing \\
\hline Kim and Hanssens & 2017 & $\begin{array}{l}\text { Advertising and Word-of-Mouth Effects on Pre-launch Consumer } \\
\text { Interest and Initial Sales of Experience Products }\end{array}$ & Journal of Interactive Marketing \\
\hline King, Racherla, and Bush & 2014 & $\begin{array}{l}\text { What We Know and Don't Know About Online Word-of-Mouth: A } \\
\text { Review and Synthesis of the Literature }\end{array}$ & Journal of Interactive Marketing \\
\hline Koch and Benlian & 2015 & $\begin{array}{l}\text { Promotional Tactics for Online Viral Marketing Campaigns: How } \\
\text { Scarcity and Personalization Affect Seed Stage Referrals }\end{array}$ & Journal of Interactive Marketing \\
\hline Labrecque & 2014 & $\begin{array}{l}\text { Fostering Consumer-Brand Relationships in Social Media } \\
\text { Environments: The Role of Parasocial Interaction }\end{array}$ & Journal of Interactive Marketing \\
\hline $\begin{array}{l}\text { Labrecque, Vor Dem Esche, Mathwick, } \\
\text { Novak, and Hofacker }\end{array}$ & 2013 & Consumer Power: Evolution in the Digital Age & Journal of Interactive Marketing \\
\hline $\begin{array}{l}\text { Langley, Hoeve, Ortt, Pals, and Van Der } \\
\text { Vecht }\end{array}$ & 2014 & Patterns of Herding and their Occurrence in an Online Setting & Journal of Interactive Marketing \\
\hline Liu, Xie, and Zhang & 2019 & $\begin{array}{l}\text { It's Not Just What You Say, But How You Say It: The Effect of } \\
\text { Language Style Matching on Perceived Quality of Consumer Reviews }\end{array}$ & Journal of Interactive Marketing \\
\hline Liu-Thompkins and Rogerson & 2012 & $\begin{array}{l}\text { Rising to Stardom: An Empirical Investigation of the Diffusion of } \\
\text { User-generated Content }\end{array}$ & Journal of Interactive Marketing \\
\hline Mafael, Gottschalk, and Kreis & 2016 & Examining Biased Assimilation of Brand-related Online Reviews & Journal of Interactive Marketing \\
\hline $\begin{array}{l}\text { Malthouse, Haenlein, Skiera, Wege, and } \\
\text { Zhang }\end{array}$ & 2013 & $\begin{array}{l}\text { Managing Customer Relationships in the Social Media Era: } \\
\text { Introducing the Social CRM House }\end{array}$ & Journal of Interactive Marketing \\
\hline Mathwick & 2002 & $\begin{array}{l}\text { Understanding the online consumer: a typology of online relational } \\
\text { norms and behavior }\end{array}$ & Journal of Interactive Marketing \\
\hline Nambisan and Baron & 2007 & $\begin{array}{l}\text { Interactions in virtual customer environments: implications for product } \\
\text { support and customer relationship management }\end{array}$ & Journal of Interactive Marketing \\
\hline $\begin{array}{l}\text { Ordovas de Almeida, Dholakia, } \\
\text { Hernandez, and Mazzon }\end{array}$ & 2014 & $\begin{array}{l}\text { The Mixed Effects of Participant Diversity and Expressive Freedom in } \\
\text { Online Peer-to-Peer Problem Solving Communities }\end{array}$ & Journal of Interactive Marketing \\
\hline Pan and Chiou & 2011 & $\begin{array}{l}\text { How Much Can You Trust Online Information? Cues for Perceived } \\
\text { Trustworthiness of Consumer-generated Online Information }\end{array}$ & Journal of Interactive Marketing \\
\hline Park and Lee & 2009 & $\begin{array}{l}\text { Antecedents of Online Reviews' Usage and Purchase Influence: An } \\
\text { Empirical Comparison of U.S. and Korean Consumers }\end{array}$ & Journal of Interactive Marketing \\
\hline $\begin{array}{l}\text { Peters, Chen, Kaplan, Ognibeni, and } \\
\text { Pauwels }\end{array}$ & 2013 & $\begin{array}{l}\text { Social Media Metrics - A Framework and Guidelines for Managing } \\
\text { Social Media }\end{array}$ & Journal of Interactive Marketing \\
\hline Purnawirawan, De Pelsmacker, and Dens & 2012 & $\begin{array}{l}\text { Balance and Sequence in Online Reviews: How Perceived Usefulness } \\
\text { Affects Attitudes and Intentions }\end{array}$ & Journal of Interactive Marketing \\
\hline $\begin{array}{l}\text { Purnawirawan, Eisend, De Pelsmacker, } \\
\text { and Dens }\end{array}$ & 2015 & $\begin{array}{l}\text { A Meta-analytic Investigation of the Role of Valence in Online } \\
\text { Reviews }\end{array}$ & Journal of Interactive Marketing \\
\hline Quesenberry and Coolsen & 2019 & $\begin{array}{l}\text { Drama Goes Viral: Effects of Story Development on Shares and Views } \\
\text { of Online Advertising Videos }\end{array}$ & Journal of Interactive Marketing \\
\hline Scarpi & 2010 & $\begin{array}{l}\text { Does Size Matter? An Examination of Small and Large Web-Based } \\
\text { Brand Communities }\end{array}$ & Journal of Interactive Marketing \\
\hline Schamari and Schaefers & 2015 & $\begin{array}{l}\text { Leaving the Home Turf: How Brands Can Use Webcare on Consumer- } \\
\text { generated Platforms to Increase Positive Consumer Engagement }\end{array}$ & Journal of Interactive Marketing \\
\hline Sen and Lerman & 2007 & $\begin{array}{l}\text { Why are you telling me this? An examination into negative consumer } \\
\text { reviews on the web }\end{array}$ & Journal of Interactive Marketing \\
\hline Seraj & 2012 & $\begin{array}{l}\text { We Create, We Connect, We Respect, Therefore We Are: Intellectual, } \\
\text { Social, and Cultural Value in Online Communities }\end{array}$ & Journal of Interactive Marketing \\
\hline Shehu, Bijmolt, and Clement & 2016 & $\begin{array}{l}\text { Effects of Likeability Dynamics on Consumers' Intention to Share } \\
\text { Online Video Advertisements }\end{array}$ & Journal of Interactive Marketing \\
\hline Smith, Fischer, and Yongjian & 2012 & $\begin{array}{l}\text { How Does Brand-related User-generated Content Differ across } \\
\text { YouTube, Facebook, and Twitter? }\end{array}$ & Journal of Interactive Marketing \\
\hline Smith, Menon, and Sivakumar & 2005 & $\begin{array}{l}\text { Online peer and editorial recommendations, trust, and choice in virtual } \\
\text { markets }\end{array}$ & Journal of Interactive Marketing \\
\hline Srivastava and Kalro & 2019 & $\begin{array}{l}\text { Enhancing the Helpfulness of Online Consumer Reviews: The Role of } \\
\text { Latent (Content) Factors }\end{array}$ & Journal of Interactive Marketing \\
\hline Thompson, Loveland, and Fombelle & 2014 & $\begin{array}{l}\text { Thematic Discrepancy Analysis: A Method to Gain Insights into } \\
\text { Lurkers and Test for Non-Response Bias }\end{array}$ & Journal of Interactive Marketing \\
\hline Van Laer, De Ruyter, and Cox & 2013 & $\begin{array}{l}\text { A Walk in Customers' Shoes: How Attentional Bias Modification } \\
\text { Affects Ownership of Integrity-violating Social Media Posts }\end{array}$ & Journal of Interactive Marketing \\
\hline Van Meter, Grisaffe, and Chonko & 2015 & $\begin{array}{l}\text { Of "Likes” and "Pins": The Effects of Consumers' Attachment to } \\
\text { Social Media }\end{array}$ & Journal of Interactive Marketing \\
\hline Van Noort and Willemsen & 2011 & $\begin{array}{l}\text { Online Damage Control: The Effects of Proactive Versus Reactive } \\
\text { Webcare Interventions in Consumer-generated and Brand-generated } \\
\text { Platforms }\end{array}$ & Journal of Interactive Marketing \\
\hline Van Noort, Voorveld, and Reijmersdal & 2012 & $\begin{array}{l}\text { Interactivity in Brand Web Sites: Cognitive, Affective, and Behavioral } \\
\text { Responses Explained by Consumers' Online Flow Experience }\end{array}$ & Journal of Interactive Marketing \\
\hline Vuylsteke, Wen, Baesens, and Poelmans & 2010 & $\begin{array}{l}\text { Consumers' Search for Information on the Internet: How and Why } \\
\text { China Differs from Western Europe }\end{array}$ & Journal of Interactive Marketing \\
\hline Wang, Yu, and Wei & 2012 & $\begin{array}{l}\text { Social Media Peer Communication and Impacts on Purchase } \\
\text { Intentions: A Consumer Socialization Framework }\end{array}$ & Journal of Interactive Marketing \\
\hline $\begin{array}{l}\text { Yadav, De Valck, Hennig-Thurau, } \\
\text { Hoffman, and Spann }\end{array}$ & 2013 & $\begin{array}{l}\text { Social Commerce: A Contingency Framework for Assessing } \\
\text { Marketing Potential }\end{array}$ & Journal of Interactive Marketing \\
\hline Yun, Park, and Ha & 2008 & $\begin{array}{l}\text { Influence of cultural dimensions on online interactive review feature } \\
\text { implementations: A comparison of Korean and U.S. retail web sites }\end{array}$ & Journal of Interactive Marketing \\
\hline Zablocki, Makri, and Houston & 2019 & $\begin{array}{l}\text { Emotions Within Online Reviews and their Influence on Product } \\
\text { Attitudes in Austria, USA and Thailand }\end{array}$ & Journal of Interactive Marketing \\
\hline Zhang and Jiang & 2014 & $\begin{array}{l}\text { Increasing Price Transparency: Implications of Consumer Price } \\
\text { Posting for Consumers' Haggling Behavior and a Seller's Pricing } \\
\text { Strategies }\end{array}$ & Journal of Interactive Marketing \\
\hline Zhao and Renard & 2018 & $\begin{array}{l}\text { Viral Promotional Advergames: How Intrinsic Playfulness and the } \\
\text { Extrinsic Value of Prizes Elicit Behavioral Responses }\end{array}$ & Journal of Interactive Marketing \\
\hline
\end{tabular}




\begin{tabular}{|c|c|c|c|}
\hline Kozinets, Hemetsberger, and Schau & 2008 & $\begin{array}{l}\text { The Wisdom of Consumer Crowds Collective Innovation in the Age of } \\
\text { Networked Marketing }\end{array}$ & Journal of Macromarketing \\
\hline Loane, Webster, and D’Alessandro & 2015 & $\begin{array}{l}\text { Identifying Consumer Value Co-created through Social Support within } \\
\text { Online Health Communities }\end{array}$ & Journal of Macromarketing \\
\hline $\begin{array}{l}\text { Berger, Humphreys, Ludwig, Moe, } \\
\text { Netzer, and Schweidel }\end{array}$ & 2019 & Uniting the Tribes: Using Text for Marketing Insight & Journal of Marketing \\
\hline Bleier, Harmeling, and Palmatier & 2019 & $\begin{array}{l}\text { Creating Effective Online } \\
\text { Customer Experiences }\end{array}$ & Journal of Marketing \\
\hline Colicev, Malshe, Pauwels, and O'Conner & 2018 & $\begin{array}{l}\text { Improving Consumer Mindset Metrics and Shareholder Value Through } \\
\text { Social Media: The Different Roles of Owned and Earned Media }\end{array}$ & Journal of Marketing \\
\hline De Vries, Gensler, and Leeflang & 2017 & $\begin{array}{l}\text { Effects of Traditional Advertising and Social Messages on Brand- } \\
\text { Building Metrics and Customer Acquisition }\end{array}$ & Journal of Marketing \\
\hline $\begin{array}{l}\text { Herhausen, Ludwig, Grewal, Wulf, and } \\
\text { Schoegel }\end{array}$ & 2019 & $\begin{array}{l}\text { Detecting, Preventing, and Mitigating Online Firestorms in Brand } \\
\text { Communities }\end{array}$ & Journal of Marketing \\
\hline Ho-Dac, Carson, and Moore & 2013 & $\begin{array}{l}\text { The Effects of Positive and Negative Online Customer Reviews: Do } \\
\text { Brand Strength and Category Maturity Matter? }\end{array}$ & Journal of Marketing \\
\hline Hoffman and Novak & 1996 & $\begin{array}{l}\text { Marketing in Hypermedia Computer-Mediated Environments: } \\
\text { Conceptual Foundations }\end{array}$ & Journal of Marketing \\
\hline Huang, Lurie, and Mitra & 2009 & $\begin{array}{l}\text { Searching for Experience on the Web: An Empirical Examination of } \\
\text { Consumer Behavior for Search and Experience Goods }\end{array}$ & Journal of Marketing \\
\hline Hughes, Swaminathan, and Brooks & 2019 & $\begin{array}{l}\text { Driving Brand Engagement Through Online Social Influencers: An } \\
\text { Empirical Investigation of Sponsored Blogging Campaigns }\end{array}$ & Journal of Marketing \\
\hline Kozinets & 2001 & $\begin{array}{l}\text { Utopian Enterprise: Articulating the Meanings of Star Trek's Culture } \\
\text { of Consumption }\end{array}$ & Journal of Marketing \\
\hline $\begin{array}{l}\text { Kozinets, De Valck, Wojnicki, and } \\
\text { Wilner }\end{array}$ & 2010 & $\begin{array}{l}\text { Networked Narratives: Understanding Word-of-Mouth Marketing in } \\
\text { Online Communities }\end{array}$ & Journal of Marketing \\
\hline Kübler, Pauwels, Yildirim, and Fandrich & 2018 & $\begin{array}{l}\text { App Popularity: Where in the world are consumers most sensitive to } \\
\text { price and user ratings }\end{array}$ & Journal of Marketing \\
\hline $\begin{array}{l}\text { Kupfer, Holte, Kübler, and Henning- } \\
\text { Thurau }\end{array}$ & 2018 & The Role of the PartnerBrand'sSocial Media Power in Brand Alliances & Journal of Marketing \\
\hline Lamberton and Stephen & 2016 & $\begin{array}{l}\text { A thematic exploration of digital, social media, and mobile marketing } \\
\text { research's evolution from } 2000 \text { to } 2015 \text { and an agenda for future } \\
\text { research }\end{array}$ & Journal of Marketing \\
\hline Liu & 2006 & $\begin{array}{l}\text { Word of Mouth for Movies: Its Dynamics and Impact on Box Office } \\
\text { Revenue }\end{array}$ & Journal of Marketing \\
\hline $\begin{array}{l}\text { Ludwig, De Ruyter, Friedman, } \\
\text { Brueggen, Wetzels, and Pfann }\end{array}$ & 2013 & $\begin{array}{l}\text { More Than Words: The Influence of Affective Content and Linguistic } \\
\text { Style Matches in Online Reviews on Conversion Rates }\end{array}$ & Journal of Marketing \\
\hline Luo, Andrews, Song, and Aspara & 2014 & Group-Buying Deal Popularity & Journal of Marketing \\
\hline Moon, Bergey, and Iacobucci & 2010 & $\begin{array}{l}\text { Dynamic Effects Among Movie Ratings, Movie Revenues, and Viewer } \\
\text { Satisfaction }\end{array}$ & Journal of Marketing \\
\hline Nam and Kannan & 2014 & The Informational Value of Social Tagging Networks & Journal of Marketing \\
\hline Naylor, Lamberton, and West & 2012 & $\begin{array}{l}\text { Beyond the "Like" Button: The Impact of Mere Virtual Presence on } \\
\text { Brand Evaluations and Purchase Intentions in Social Media Settings }\end{array}$ & Journal of Marketing \\
\hline Schau, Muniz, and Arnould & 2009 & How Brand Community Practices Create Value & Journal of Marketing \\
\hline Schulze, Scholer, and Skiera & 2014 & Not All Fun and Games: Viral Marketing for Utilitarian Products & Journal of Marketing \\
\hline Sridhar and Srinivasan & 2012 & Social Influence Effects in Online Product Ratings & Journal of Marketing \\
\hline Tang, Fang, and Wang & 2014 & $\begin{array}{l}\text { Is Neutral Really Neutral? The Effects of Neutral User-Generated } \\
\text { Content on Product Sales }\end{array}$ & Journal of Marketing \\
\hline Tellis, MacInnis, Tirunillai, and Zhang & 2019 & $\begin{array}{l}\text { What drives virality (sharing) of online digital content? The critical } \\
\text { role of information, emotion, and brand prominence }\end{array}$ & Journal of Marketing \\
\hline Trusov, Bucklin, and Pauwels & 2009 & $\begin{array}{l}\text { Effects of Word-of-Mouth Versus Traditional Marketing: Findings } \\
\text { from an Internet Social Networking Site }\end{array}$ & Journal of Marketing \\
\hline Watson, Pocheptsova Ghosh, and Trusov & 2018 & $\begin{array}{l}\text { Swayed by the Numbers: The Consequences of Displaying Product } \\
\text { Review Attributes }\end{array}$ & Journal of Marketing \\
\hline Yadav and Pavlou & 2013 & $\begin{array}{l}\text { Marketing in Computer-Mediated Environments: Research Synthesis } \\
\text { and New Directions }\end{array}$ & Journal of Marketing \\
\hline You, Vadakkepatt, and Joshi & 2015 & A Meta-Analysis of Electronic Word-of-Mouth Elasticity & Journal of Marketing \\
\hline Zhu and Zhang & 2010 & $\begin{array}{l}\text { Impact of Online Consumer Reviews on Sales: The Moderating Role } \\
\text { of Product and Consumer Characteristics }\end{array}$ & Journal of Marketing \\
\hline Abendroth and Heyman & 2013 & $\begin{array}{l}\text { Honesty is the best policy: The effects of disclosure in word-of-mouth } \\
\text { marketing }\end{array}$ & $\begin{array}{l}\text { Journal of Marketing } \\
\text { Communications }\end{array}$ \\
\hline Anghelcev & 2015 & $\begin{array}{l}\text { Unintended effects of incentivizing consumers to recommend a } \\
\text { favorite brand }\end{array}$ & $\begin{array}{l}\text { Journal of Marketing } \\
\text { Communications }\end{array}$ \\
\hline Bailey & 2004 & $\begin{array}{l}\text { Thiscompanysucks.com: the use of the Internet in negative consumer- } \\
\text { to-consumer articulations }\end{array}$ & $\begin{array}{l}\text { Journal of Marketing } \\
\text { Communications }\end{array}$ \\
\hline Barnes and Jacobsen & 2014 & $\begin{array}{l}\text { Missed eWOM opportunities: A cross-sector analysis of online } \\
\text { monitoring behavior }\end{array}$ & $\begin{array}{l}\text { Journal of Marketing } \\
\text { Communications }\end{array}$ \\
\hline Casalo, Flavian, and Guinaliu & 2008 & $\begin{array}{l}\text { Promoting Consumer's Participation in Virtual Brand Communities: A } \\
\text { New Paradigm in Branding Strategy }\end{array}$ & $\begin{array}{l}\text { Journal of Marketing } \\
\text { Communications }\end{array}$ \\
\hline Colliander and Erlandsson & 2015 & $\begin{array}{l}\text { The blog and the bountiful: Exploring the effects of disguised product } \\
\text { placement on blogs that are revealed by a third party }\end{array}$ & $\begin{array}{l}\text { Journal of Marketing } \\
\text { Communications }\end{array}$ \\
\hline Daugherty and Hoffman & 2014 & $\begin{array}{l}\text { eWOM and the importance of capturing consumer attention within } \\
\text { social media }\end{array}$ & $\begin{array}{l}\text { Journal of Marketing } \\
\text { Communications }\end{array}$ \\
\hline Donlan and Crowther & 2014 & $\begin{array}{l}\text { Leveraging sponsorship to achieve consumer relationship objectives } \\
\text { through the creation of 'marketing spaces': An exploratory study }\end{array}$ & $\begin{array}{l}\text { Journal of Marketing } \\
\text { Communications }\end{array}$ \\
\hline Goodrich and De Mooij & 2014 & $\begin{array}{l}\text { How 'social' are social media? A cross-cultural comparison of online } \\
\text { and offline purchase decision influences }\end{array}$ & $\begin{array}{l}\text { Journal of Marketing } \\
\text { Communications }\end{array}$ \\
\hline Groeger and Buttle & 2014 & $\begin{array}{l}\text { Word-of-mouth marketing influence on offline and online } \\
\text { communications: Evidence from case study research }\end{array}$ & $\begin{array}{l}\text { Journal of Marketing } \\
\text { Communications }\end{array}$ \\
\hline Jepsen & 2006 & $\begin{array}{l}\text { Information Search in Virtual Communities: Is it Replacing Use of } \\
\text { Off-Line Communication? }\end{array}$ & $\begin{array}{l}\text { Journal of Marketing } \\
\text { Communications }\end{array}$ \\
\hline
\end{tabular}




\begin{tabular}{|c|c|c|c|}
\hline Kimmel and Kitchen & 2014 & $\begin{array}{l}\text { WOM and social media: Presaging future directions for research and } \\
\text { practice }\end{array}$ & $\begin{array}{l}\text { Journal of Marketing } \\
\text { Communications }\end{array}$ \\
\hline Lorenzon and Russell & 2012 & $\begin{array}{l}\text { From apathy to ambivalence: How is persuasion knowledge reflected } \\
\text { in consumers' comments about in-game advertising? }\end{array}$ & $\begin{array}{l}\text { Journal of Marketing } \\
\text { Communications }\end{array}$ \\
\hline Lueck & 2015 & $\begin{array}{l}\text { Friend-zone with benefits: The parasocial advertising of Kim } \\
\text { Kardashian }\end{array}$ & $\begin{array}{l}\text { Journal of Marketing } \\
\text { Communications }\end{array}$ \\
\hline Mason & 2008 & Word of mouth as a promotional tool for turbulent markets & $\begin{array}{l}\text { Journal of Marketing } \\
\text { Communications }\end{array}$ \\
\hline Pace, Balboni, and Gistri & 2014 & $\begin{array}{l}\text { The effects of social media on brand attitude and WOM during a brand } \\
\text { crisis: Evidences from the Barilla case }\end{array}$ & $\begin{array}{l}\text { Journal of Marketing } \\
\text { Communications }\end{array}$ \\
\hline Pfeffer, Zorbach, and Carley & 2014 & $\begin{array}{l}\text { Understanding online firestorms: Negative word-of-mouth dynamics in } \\
\text { social media networks }\end{array}$ & $\begin{array}{l}\text { Journal of Marketing } \\
\text { Communications }\end{array}$ \\
\hline Reichelt, Sievert, and Jacob & 2014 & $\begin{array}{l}\text { How credibility affects eWOM reading: The influences of expertise, } \\
\text { trustworthiness, and similarity on utilitarian and social functions }\end{array}$ & $\begin{array}{l}\text { Journal of Marketing } \\
\text { Communications }\end{array}$ \\
\hline Toder-Alon, Brunel, and Fournier & 2014 & Word-of-mouth rhetorics in social media talk & $\begin{array}{l}\text { Journal of Marketing } \\
\text { Communications }\end{array}$ \\
\hline Uzunoglu and Oksuz & 2014 & $\begin{array}{l}\text { New opportunities in social media for ad-restricted alcohol products: } \\
\text { The case of 'Yeni Rakı' }\end{array}$ & $\begin{array}{l}\text { Journal of Marketing } \\
\text { Communications }\end{array}$ \\
\hline $\begin{array}{l}\text { Van Noort, Angteunis, and Van } \\
\text { Reijmersdal }\end{array}$ & 2012 & $\begin{array}{l}\text { Social connections and the persuasiveness of viral campaigns in social } \\
\text { network sites: Persuasive intent as the underlying mechanism }\end{array}$ & $\begin{array}{l}\text { Journal of Marketing } \\
\text { Communications }\end{array}$ \\
\hline Yeh and Choi & 2011 & $\begin{array}{l}\text { MINI-lovers, maxi-mouths: An investigation of antecedents to eWOM } \\
\text { intention among brand community members }\end{array}$ & $\begin{array}{l}\text { Journal of Marketing } \\
\text { Communications }\end{array}$ \\
\hline Archer-Brown, Piercy, and Joinson & 2013 & $\begin{array}{l}\text { Examining the information value of virtual communities: Factual } \\
\text { versus opinion-based message content }\end{array}$ & $\begin{array}{l}\text { Journal of Marketing } \\
\text { Management }\end{array}$ \\
\hline $\begin{array}{l}\text { Bianchi, Andrews, Wiese, and Fazal-E- } \\
\text { Hasan }\end{array}$ & 2017 & Consumer intentions to engage in s-commerce: a cross-national study & $\begin{array}{l}\text { Journal of Marketing } \\
\text { Management }\end{array}$ \\
\hline Burton and Khammash & 2010 & Why do people read reviews posted on consumer-opinion portals? & $\begin{array}{l}\text { Journal of Marketing } \\
\text { Management }\end{array}$ \\
\hline Buttle and Groeger & 2017 & $\begin{array}{l}\text { Who says what to whom in what channel? A rules theoretic } \\
\text { perspective on word-of-mouth marketing }\end{array}$ & $\begin{array}{l}\text { Journal of Marketing } \\
\text { Management }\end{array}$ \\
\hline Canhoto and Clark & 2013 & Customer service 140 characters at a time: The users' perspective & $\begin{array}{l}\text { Journal of Marketing } \\
\text { Management }\end{array}$ \\
\hline Cluley and Brown & 2015 & The dividualised consumer: sketching the new mask of the consumer & $\begin{array}{l}\text { Journal of Marketing } \\
\text { Management }\end{array}$ \\
\hline Cova and White & 2010 & $\begin{array}{l}\text { Counter-brand and alter-brand communities: The impact of Web } 2.0 \\
\text { on tribal marketing approaches }\end{array}$ & $\begin{array}{l}\text { Journal of Marketing } \\
\text { Management }\end{array}$ \\
\hline Croft & 2013 & $\begin{array}{l}\text { Blessed are the geeks: An ethnographic study of consumer networks in } \\
\text { social media, 2006-2012 }\end{array}$ & $\begin{array}{l}\text { Journal of Marketing } \\
\text { Management }\end{array}$ \\
\hline Floh, Koller, and Zauner & 2013 & $\begin{array}{l}\text { Taking a deeper look at online reviews: The asymmetric effect of } \\
\text { valence intensity on shopping behaviour }\end{array}$ & $\begin{array}{l}\text { Journal of Marketing } \\
\text { Management }\end{array}$ \\
\hline Grant, Clarke, and Kyriazis & 2007 & $\begin{array}{l}\text { A review of factors affecting online consumer search behaviour from } \\
\text { an information value perspective }\end{array}$ & $\begin{array}{l}\text { Journal of Marketing } \\
\text { Management }\end{array}$ \\
\hline Hamilton and Hewer & 2010 & $\begin{array}{l}\text { Tribal mattering spaces: Social-networking sites, celebrity affiliations, } \\
\text { and tribal innovations }\end{array}$ & $\begin{array}{l}\text { Journal of Marketing } \\
\text { Management }\end{array}$ \\
\hline Harwood and Garry & 2010 & $\begin{array}{l}\text { It's Mine!' - Participation and ownership within virtual co-creation } \\
\text { environments }\end{array}$ & $\begin{array}{l}\text { Journal of Marketing } \\
\text { Management }\end{array}$ \\
\hline Hewer and Brownlie & 2010 & $\begin{array}{l}\text { On market forces and adjustments: acknowledging consumer creativity } \\
\text { through the aesthetics of 'debadging' }\end{array}$ & $\begin{array}{l}\text { Journal of Marketing } \\
\text { Management }\end{array}$ \\
\hline Huang & 2010 & $\begin{array}{l}\text { Social contagion effects in experiential information exchange on } \\
\text { bulletin board systems }\end{array}$ & $\begin{array}{l}\text { Journal of Marketing } \\
\text { Management }\end{array}$ \\
\hline Jones, Temperley, and Lima & 2009 & Corporate reputation in the era of Web 2.0: the case of Primark & $\begin{array}{l}\text { Journal of Marketing } \\
\text { Management }\end{array}$ \\
\hline Jung, Ineson, and Green & 2013 & Online social networking: Relationship marketing in UK hotels & $\begin{array}{l}\text { Journal of Marketing } \\
\text { Management }\end{array}$ \\
\hline Kim, Choi, Qualls, and Han & 2008 & $\begin{array}{l}\text { It takes a marketplace community to raise brand commitment: the role } \\
\text { of online communities }\end{array}$ & $\begin{array}{l}\text { Journal of Marketing } \\
\text { Management }\end{array}$ \\
\hline Kozinets, Scaraboto, and Parmentier & 2018 & $\begin{array}{l}\text { Evolving netnography: how brand autonetnography, a netnographic } \\
\text { sensibility, and more-than-human netnography can transform your } \\
\text { research }\end{array}$ & $\begin{array}{l}\text { Journal of Marketing } \\
\text { Management }\end{array}$ \\
\hline Laing, Keeling, and Newholm & 2011 & $\begin{array}{l}\text { Virtual communities come of age: Parallel service, value, and } \\
\text { propositions offered in communal online space }\end{array}$ & $\begin{array}{l}\text { Journal of Marketing } \\
\text { Management }\end{array}$ \\
\hline Liang, Ekinci, Occhiocupo, and Whyatt & 2013 & Antecedents of travellers' electronic word-of-mouth communication & $\begin{array}{l}\text { Journal of Marketing } \\
\text { Management }\end{array}$ \\
\hline Lugosi and Quinton & 2018 & More-than-human netnography & $\begin{array}{l}\text { Journal of Marketing } \\
\text { Management }\end{array}$ \\
\hline Oakes, Dennis, and Oakes & 2013 & Web-based forums and metaphysical branding & $\begin{array}{l}\text { Journal of Marketing } \\
\text { Management }\end{array}$ \\
\hline O'Sullivan & 2010 & $\begin{array}{l}\text { Dangling conversations: Web-forum use by a symphony orchestra's } \\
\text { audience members }\end{array}$ & $\begin{array}{l}\text { Journal of Marketing } \\
\text { Management }\end{array}$ \\
\hline Palmer and Huo & 2013 & $\begin{array}{l}\text { A study of trust over time within a social network mediated } \\
\text { environment }\end{array}$ & $\begin{array}{l}\text { Journal of Marketing } \\
\text { Management }\end{array}$ \\
\hline Palmer and Koenig-Lewis & 2011 & $\begin{array}{l}\text { The effects of pre-enrollment emotions and peer group interaction on } \\
\text { students' satisfaction }\end{array}$ & $\begin{array}{l}\text { Journal of Marketing } \\
\text { Management }\end{array}$ \\
\hline Phillips and Broderick & 2014 & $\begin{array}{l}\text { Has Mumsnet changed me? SNS influence on identity adaptation and } \\
\text { consumption }\end{array}$ & $\begin{array}{l}\text { Journal of Marketing } \\
\text { Management }\end{array}$ \\
\hline Quinton & 2013 & $\begin{array}{l}\text { The community brand paradigm: A response to brand management's } \\
\text { dilemma in the digital era }\end{array}$ & $\begin{array}{l}\text { Journal of Marketing } \\
\text { Management }\end{array}$ \\
\hline Reid and Duffy & 2018 & $\begin{array}{l}\text { A netnographic sensibility: developing the netnographic/ social } \\
\text { listening boundaries }\end{array}$ & $\begin{array}{l}\text { Journal of Marketing } \\
\text { Management }\end{array}$ \\
\hline Rokka, Karlsson, and Tienari & 2014 & Balancing acts: Managing employees and reputation in social media & $\begin{array}{l}\text { Journal of Marketing } \\
\text { Management }\end{array}$ \\
\hline
\end{tabular}




\begin{tabular}{|c|c|c|c|}
\hline Soboleva, Burton, Mallik, and Khan & 2017 & $\begin{array}{l}\text { 'Retweet for a Chance to...': an analysis of what triggers consumers to } \\
\text { engage in seeded eWOM on Twitter }\end{array}$ & $\begin{array}{l}\text { Journal of Marketing } \\
\text { Management }\end{array}$ \\
\hline Valos, Maplestone, Polonsky, and Ewing & 2017 & $\begin{array}{l}\text { Integrating social media within an integrated marketing } \\
\text { communication decision-making framework }\end{array}$ & $\begin{array}{l}\text { Journal of Marketing } \\
\text { Management }\end{array}$ \\
\hline $\begin{array}{l}\text { Valos, Polonsky, Mavondo, and } \\
\text { Lipscomb }\end{array}$ & 2015 & $\begin{array}{l}\text { Senior marketers' insights into the challenges of social media } \\
\text { implementation in large organisations: assessing generic and electronic } \\
\text { orientation models as potential solutions }\end{array}$ & $\begin{array}{l}\text { Journal of Marketing } \\
\text { Management }\end{array}$ \\
\hline Villegas & 2017 & $\begin{array}{l}\text { From the self to the screen: a journey guide for auto-netnography in } \\
\text { online communities }\end{array}$ & $\begin{array}{l}\text { Journal of Marketing } \\
\text { Management }\end{array}$ \\
\hline Wolny and Mueller & 2013 & $\begin{array}{l}\text { Analysis of fashion consumers' motives to engage in electronic word- } \\
\text { of-mouth communication through social media platforms }\end{array}$ & $\begin{array}{l}\text { Journal of Marketing } \\
\text { Management }\end{array}$ \\
\hline Yang, Lin, Carlson, and Ross & 2015 & $\begin{array}{l}\text { Brand engagement on social media: will firms' social media efforts } \\
\text { influence search engine advertising effectiveness? }\end{array}$ & $\begin{array}{l}\text { Journal of Marketing } \\
\text { Management }\end{array}$ \\
\hline Akpinar and Berger & 2017 & Valuable Virality & Journal of Marketing Research \\
\hline Anderson and Simester & 2014 & $\begin{array}{l}\text { Reviews Without a Purchase: Low Ratings, Loyal Customers, and } \\
\text { Deception }\end{array}$ & Journal of Marketing Research \\
\hline Ansari, Essegaier, and Kohli & 2000 & Internet Recommendation Systems & Journal of Marketing Research \\
\hline $\begin{array}{l}\text { Babic Rosario, Sotgiu, De Valck, and } \\
\text { Bijmolt }\end{array}$ & 2016 & $\begin{array}{l}\text { The Effect of Electronic Word of Mouth on Sales: A Meta-Analytic } \\
\text { Review of Platform, Product, and Metric Factors }\end{array}$ & Journal of Marketing Research \\
\hline Baker, Donthu, and Kumar & 2016 & $\begin{array}{l}\text { Investigating How Word-of-Mouth Conversations About Brands } \\
\text { Influence Purchase and Retransmission Intentions }\end{array}$ & Journal of Marketing Research \\
\hline Barasch and Berger & 2014 & $\begin{array}{l}\text { Broadcasting and Narrowcasting: How Audience Size Affects What } \\
\text { People Share }\end{array}$ & Journal of Marketing Research \\
\hline Berger and Milkman & 2012 & What Makes Online Content Viral? & Journal of Marketing Research \\
\hline Berger and Schwartz & 2011 & What drives immediate and ongoing word of Mouth? & Journal of Marketing Research \\
\hline Bond, He, and Wen & 2019 & $\begin{array}{l}\text { Speaking for "Free": Word of Mouth } \\
\text { in Free- and Paid-Product Settings }\end{array}$ & Journal of Marketing Research \\
\hline Borah and Tellis & 2016 & $\begin{array}{l}\text { Halo (Spillover) Effects in Social Media: Do Product Recalls of One } \\
\text { Brand Hurt or Help Rival Brands? }\end{array}$ & Journal of Marketing Research \\
\hline Bruce, Foutz, and Kolsarici & 2012 & $\begin{array}{l}\text { Dynamic Effectiveness of Advertising and Word of Mouth in } \\
\text { Sequential Distribution of New Products }\end{array}$ & Journal of Marketing Research \\
\hline Chen and Lurie & 2013 & $\begin{array}{l}\text { Temporal Contiguity and Negativity Bias in the Impact of Online } \\
\text { Word of Mouth }\end{array}$ & Journal of Marketing Research \\
\hline Chen, Lans, and Phan & 2017 & $\begin{array}{l}\text { Uncovering the Importance of Relationship Characteristics in Social } \\
\text { Networks: Implications for Seeding Strategies }\end{array}$ & Journal of Marketing Research \\
\hline Chen, Wang, and Xie & 2011 & $\begin{array}{l}\text { Online Social Interactions: A Natural Experiment on Word of Mouth } \\
\text { Versus Observational Learning }\end{array}$ & Journal of Marketing Research \\
\hline Chevalier and Mayzlin & 2006 & The Effect of Word of Mouth on Sales: Online Book Reviews & Journal of Marketing Research \\
\hline Chica and Rand & 2017 & $\begin{array}{l}\text { Building Agent-Based Decision Support Systems for Word-of-Mouth } \\
\text { Programs: A Freemium Application }\end{array}$ & Journal of Marketing Research \\
\hline Chung and Rao & 2012 & $\begin{array}{l}\text { A General Consumer Preference Model for Experience Products: } \\
\text { Application to Internet Recommendation Services }\end{array}$ & Journal of Marketing Research \\
\hline $\begin{array}{l}\text { De Angelis, Bonezzi, Peluso, Rucker, } \\
\text { and Costabile }\end{array}$ & 2012 & $\begin{array}{l}\text { On Braggarts and Gossips: A Self- Enhancement Account of Word-of- } \\
\text { Mouth Generation and Transmission }\end{array}$ & Journal of Marketing Research \\
\hline Dubois, Bonezzi, and Angelis & 2016 & $\begin{array}{l}\text { Sharing with Friends Versus Strangers: How Interpersonal Closeness } \\
\text { Influences Word-of-Mouth Valence }\end{array}$ & Journal of Marketing Research \\
\hline Dubois, Rucker, and Tormala & 2011 & $\begin{array}{l}\text { From Rumors to Facts, and Facts to Rumors: The Role of Certainty } \\
\text { Decay in Consumer Communications }\end{array}$ & Journal of Marketing Research \\
\hline Gelper, Peres, and Eliashberg & 2018 & $\begin{array}{l}\text { Talk Bursts: The Role of Spikes in Pre-release Word-of-Mouth } \\
\text { Dynamics }\end{array}$ & Journal of Marketing Research \\
\hline Gong, Zhang, Zhao, and Jiang & 2017 & Tweeting as a Marketing Tool: A Field Experiment in the TV Industry & Journal of Marketing Research \\
\hline Grewal and Stephen & 2019 & $\begin{array}{l}\text { In Mobile We Trust: The Effects of Mobile Versus Nonmobile } \\
\text { Reviews on Consumer Purchase Intentions }\end{array}$ & Journal of Marketing Research \\
\hline Grewal, Stephen, and Coleman & 2019 & $\begin{array}{l}\text { When Posting About Products on Social Media Backfires: The } \\
\text { Negative Effects of Consumer Identity Signaling on Product Interest }\end{array}$ & Journal of Marketing Research \\
\hline Hamilton, Schlosser, and Chen & 2017 & $\begin{array}{l}\text { Who's Driving This Conversation? Systematic Biases in the Content } \\
\text { of Online Consumer Discussions }\end{array}$ & Journal of Marketing Research \\
\hline Hollenbeck & 2018 & $\begin{array}{l}\text { Online Reputation Mechanisms and the Decreasing Value of Chain } \\
\text { Affiliation }\end{array}$ & Journal of Marketing Research \\
\hline Homburg, Ehm, and Artz & 2015 & $\begin{array}{l}\text { Measuring and Managing Consumer Sentiment in an Online } \\
\text { Community Environment }\end{array}$ & Journal of Marketing Research \\
\hline Kozinets & 2002 & $\begin{array}{l}\text { The Field Behind the Screen: Using Netnography for Marketing } \\
\text { Research in Online Communities }\end{array}$ & Journal of Marketing Research \\
\hline Lee and Bradlow & 2011 & Automated marketing research: Using online customer reviews & Journal of Marketing Research \\
\hline Liu, Steenkamp, and Zhang & 2018 & $\begin{array}{l}\text { Agglomeration as a Driver of the Volume of ElectronicWord of Mouth } \\
\text { in the Restaurant Industry }\end{array}$ & Journal of Marketing Research \\
\hline Lovett, Peres, and Shachar & 2013 & On Brands and Word of Mouth & Journal of Marketing Research \\
\hline Luo, Chen, Han, and Park & 2010 & $\begin{array}{l}\text { Dilution and Enhancement of Celebrity Brands Through Sequential } \\
\text { Movie Releases }\end{array}$ & Journal of Marketing Research \\
\hline Melumad, Inman, and Pham & 2019 & $\begin{array}{l}\text { Selectively emotional: How smartphone use changes user-generated } \\
\text { content }\end{array}$ & Journal of Marketing Research \\
\hline Mochon, Johnson, Schwartz, and Ariely & 2017 & What Are Likes Worth? A Facebook Page Field Experiment & Journal of Marketing Research \\
\hline Moe and Trusov & 2011 & The Value of Social Dynamics in Online Product Ratings Forums & Journal of Marketing Research \\
\hline Naylor, Lamberton, and Norton & 2011 & $\begin{array}{l}\text { Seeing ourselves in others: Reviewer ambiguity, egocentric anchoring, } \\
\text { and Persuasion }\end{array}$ & Journal of Marketing Research \\
\hline Packard and Berger & 2017 & How Language Shapes Word of Mouth’s Impact & Journal of Marketing Research \\
\hline Paharia, Avery, and Keinan & 2014 & Positioning Brands Against Large Competitors to Increase Sales & Journal of Marketing Research \\
\hline Peng, Agarwal, Hosanagar, and Iyengar & 2018 & Network Overlap and Content Sharing on Social Media Platforms & Journal of Marketing Research \\
\hline Schweidel and Moe & 2014 & $\begin{array}{l}\text { Listening in on Social Media: A Joint Model of Sentiment and Venue } \\
\text { Format Choice }\end{array}$ & Journal of Marketing Research \\
\hline
\end{tabular}




\begin{tabular}{|c|c|c|c|}
\hline Stephen and Galak & 2012 & $\begin{array}{l}\text { The Effects of Traditional and Social Earned Media on Sales: A Study } \\
\text { of a Microlending Marketplace }\end{array}$ & Journal of Marketing Research \\
\hline Tirunillai and Tellis & 2014 & $\begin{array}{l}\text { Mining Marketing Meaning from Online Chatter: Strategic Brand } \\
\text { Analysis of Big Data Using Latent Dirichlet Allocation }\end{array}$ & Journal of Marketing Research \\
\hline Wang and Chaudhry & 2018 & $\begin{array}{l}\text { When and How Managers' Responses to Online Reviews Affect } \\
\text { Subsequent Reviews }\end{array}$ & Journal of Marketing Research \\
\hline Yin, Bond, and Zhang & 2017 & $\begin{array}{l}\text { Keep Your Cool or Let It Out: Nonlinear Effects of Expressed Arousal } \\
\text { on Perceptions of Consumer Reviews }\end{array}$ & Journal of Marketing Research \\
\hline Ying, Feinberg, and Wedel & 2006 & $\begin{array}{l}\text { Leveraging Missing Ratings to Improve Online Recommendation } \\
\text { Systems }\end{array}$ & Journal of Marketing Research \\
\hline Zhao and Xie & 2011 & $\begin{array}{l}\text { Effects of Social and Temporal Distance on Consumers' Responses to } \\
\text { Peer Recommendations }\end{array}$ & Journal of Marketing Research \\
\hline Zhu, Dholakia, Chen, and Algesheimer & 2012 & $\begin{array}{l}\text { Does Online Community Participation Foster Risky Financial } \\
\text { Behavior? }\end{array}$ & Journal of Marketing Research \\
\hline Barry and Gironda & 2018 & $\begin{array}{l}\text { A dyadic examination of inspirational factors driving B2B social } \\
\text { media influence }\end{array}$ & $\begin{array}{l}\text { Journal of Marketing Theory } \\
\text { and Practice }\end{array}$ \\
\hline Barry and Graca & 2018 & Humor effectiveness in social video engagement & $\begin{array}{l}\text { Journal of Marketing Theory } \\
\text { and Practice }\end{array}$ \\
\hline Bruce and Solomon & 2013 & Managing for media anarchy: a corporate marketing perspective & $\begin{array}{l}\text { Journal of Marketing Theory } \\
\text { and Practice }\end{array}$ \\
\hline Carvalho and Fernandes & 2018 & $\begin{array}{l}\text { Understanding Customer Brand Engagement with Virtual Social } \\
\text { Communities: A Comprehensive Model of Drivers, Outcomes and } \\
\text { Moderators }\end{array}$ & $\begin{array}{l}\text { Journal of Marketing Theory } \\
\text { and Practice }\end{array}$ \\
\hline Dabholkar & 2006 & $\begin{array}{l}\text { Factors influencing consumer choice of a "rating web site": an } \\
\text { experimental investigation of an online interactive decision aid }\end{array}$ & $\begin{array}{l}\text { Journal of Marketing Theory } \\
\text { and Practice }\end{array}$ \\
\hline Fujita, Harrigan, and Soutar & 2018 & $\begin{array}{l}\text { Capturing and co-creating student experiences in social media: A } \\
\text { social identity theory perspective }\end{array}$ & $\begin{array}{l}\text { Journal of Marketing Theory } \\
\text { and Practice }\end{array}$ \\
\hline Kim and Chandler & 2018 & $\begin{array}{l}\text { How social community and social publishing influence new product } \\
\text { launch: The case of Twitter during the Playstation } 4 \text { and Xbox One } \\
\text { launches }\end{array}$ & $\begin{array}{l}\text { Journal of Marketing Theory } \\
\text { and Practice }\end{array}$ \\
\hline Kuo and Nakhata & 2019 & The Impact of Electronic Word-of-Mouth on Customer Satisfaction & $\begin{array}{l}\text { Journal of Marketing Theory } \\
\text { and Practice }\end{array}$ \\
\hline Pihlaja, Saarijarvi, Spence, and Yrjola & 2017 & From electronic WOM to social WOM: Bridging the trust deficit & $\begin{array}{l}\text { Journal of Marketing Theory } \\
\text { and Practice }\end{array}$ \\
\hline Porter, Donthu, and Baker & 2012 & Gender differences in trust formation in virtual communities & $\begin{array}{l}\text { Journal of Marketing Theory } \\
\text { and Practice }\end{array}$ \\
\hline Ramirez, Gau, Hadjimarcou, and $\mathrm{Xu}$ & 2018 & User-generated content as word-of-mouth & $\begin{array}{l}\text { Journal of Marketing Theory } \\
\text { and Practice }\end{array}$ \\
\hline Syrdal and Briggs & 2018 & Engagement with Social Media Content: A Qualitative Exploration & $\begin{array}{l}\text { Journal of Marketing Theory } \\
\text { and Practice }\end{array}$ \\
\hline Thakur, Hale, and Summey & 2018 & What Motivates Consumers to Partake in Cyber shilling? & $\begin{array}{l}\text { Journal of Marketing Theory } \\
\text { and Practice }\end{array}$ \\
\hline Wilk, Harrigan, and Soutar & 2018 & Navigating online brand advocacy (OBA): An exploratory analysis & $\begin{array}{l}\text { Journal of Marketing Theory } \\
\text { and Practice }\end{array}$ \\
\hline Chauhan and Pillai & 2013 & $\begin{array}{l}\text { Role of content strategy in social media brand communities: a case of } \\
\text { higher education institutes in India }\end{array}$ & $\begin{array}{l}\text { Journal of Product and Brand } \\
\text { Management }\end{array}$ \\
\hline De Maeyer & 2012 & $\begin{array}{l}\text { Impact of online consumer reviews on sales and price strategies: a } \\
\text { review and directions for future research }\end{array}$ & $\begin{array}{l}\text { Journal of Product and Brand } \\
\text { Management }\end{array}$ \\
\hline Dessart, Veloutsou, and Morgan-Thomas & 2015 & $\begin{array}{l}\text { Consumer engagement in online brand communities: a social media } \\
\text { perspective }\end{array}$ & $\begin{array}{l}\text { Journal of Product and Brand } \\
\text { Management }\end{array}$ \\
\hline Hollebeek and Chen & 2014 & $\begin{array}{l}\text { Exploring positively- versus negatively-valenced brand engagement: a } \\
\text { conceptual model }\end{array}$ & $\begin{array}{l}\text { Journal of Product and Brand } \\
\text { Management }\end{array}$ \\
\hline Ullrich and Brunner & 2015 & Negative online consumer reviews: effects of different responses & $\begin{array}{l}\text { Journal of Product and Brand } \\
\text { Management }\end{array}$ \\
\hline Wallace, Buil, and Chernatony & 2014 & $\begin{array}{l}\text { Consumer engagement with self-expressive brands: brand love and } \\
\text { WOM outcomes }\end{array}$ & $\begin{array}{l}\text { Journal of Product and Brand } \\
\text { Management }\end{array}$ \\
\hline Droge, Stanko, and Pollitte & 2010 & $\begin{array}{l}\text { Lead Users and Early Adopters on the Web: The Role of New } \\
\text { Technology Product Blogs }\end{array}$ & $\begin{array}{l}\text { Journal of Product Innovation } \\
\text { Management }\end{array}$ \\
\hline Fueller, Matzler, and Hoppe & 2008 & Brand Community Members as a Source of Innovation & $\begin{array}{l}\text { Journal of Product Innovation } \\
\text { Management }\end{array}$ \\
\hline Ashley and Leonard & 2009 & $\begin{array}{l}\text { Betrayed by the Buzz? Covert Content and Consumer-Brand } \\
\text { Relationships }\end{array}$ & $\begin{array}{l}\text { Journal of Public Policy and } \\
\text { Marketing }\end{array}$ \\
\hline $\mathrm{Lin}, \mathrm{Lu}$, and $\mathrm{Wu}$ & 2012 & The Effects of Visual Information in eWOM Communication & $\begin{array}{l}\text { Journal of Research in } \\
\text { Interactive Marketing }\end{array}$ \\
\hline Duan, Gu, and Whinston & 2008 & $\begin{array}{l}\text { The Dynamics of Online Word-of-Mouth and Product Sales - An } \\
\text { Empirical Investigation of the Movie Industry }\end{array}$ & Journal of Retailing \\
\hline $\begin{array}{l}\text { Floyd, Freling, Alhoqail, Cho, and } \\
\text { Freling }\end{array}$ & 2014 & How Online Product Reviews Affect Retail Sales: A Meta-analysis & Journal of Retailing \\
\hline Jin, $\mathrm{Hu}$, and $\mathrm{He}$ & 2014 & $\begin{array}{l}\text { The Recent versus The Out-Dated: An Experimental Examination of } \\
\text { the Time-Variant Effects of Online Consumer Reviews }\end{array}$ & Journal of Retailing \\
\hline Khare, Labrecque, and Asare & 2011 & $\begin{array}{l}\text { The Assimilative and Contrastive Effects of Word-of-Mouth Volume: } \\
\text { An Experimental Examination of Online Consumer Ratings }\end{array}$ & Journal of Retailing \\
\hline Minnema, Bijmolt, Gensler, and Wiesel & 2016 & $\begin{array}{l}\text { To keep or not to keep: Effects of online customer reviews on product } \\
\text { returns }\end{array}$ & Journal of Retailing \\
\hline Moon and Song & 2015 & $\begin{array}{l}\text { The Roles of Cultural Elements in International Retailing of Cultural } \\
\text { Products: An Application to the Motion Picture Industry }\end{array}$ & Journal of Retailing \\
\hline Nejad, Amini, and Babakus & 2015 & Success Factors in Product Seeding: The Role of Homophily & Journal of Retailing \\
\hline Pan and Zhang & 2011 & $\begin{array}{l}\text { Born Unequal: A Study of the Helpfulness of User-Generated Product } \\
\text { Reviews }\end{array}$ & Journal of Retailing \\
\hline Senecal and Nantel & 2004 & $\begin{array}{l}\text { The influence of online product recommendations on consumers' } \\
\text { online choices }\end{array}$ & Journal of Retailing \\
\hline
\end{tabular}




\begin{tabular}{|c|c|c|c|}
\hline Wang, Liu, and Fang & 2015 & $\begin{array}{l}\text { User Reviews Variance, Critic Reviews Variance, and Product Sales: } \\
\text { An Exploration of Customer Breadth and Depth Effects }\end{array}$ & Journal of Retailing \\
\hline $\begin{array}{l}\text { Ahani, Nilashi, Yadegaridehkordi, } \\
\text { Sanzogni, Tarik, Knox, Samad, and } \\
\text { Ibrahim }\end{array}$ & 2019 & $\begin{array}{l}\text { Revealing customers' satisfaction and preferences through online } \\
\text { review analysis: The case of Canary Islands hotels }\end{array}$ & $\begin{array}{l}\text { Journal of Retailing and } \\
\text { Consumer Services }\end{array}$ \\
\hline Augusto and Torres & 2018 & $\begin{array}{l}\text { Effects of brand attitude and eWOM on consumers' willingness to pay } \\
\text { in the banking industry: Mediating role of consumer-brand } \\
\text { identification and brand equity }\end{array}$ & $\begin{array}{l}\text { Journal of Retailing and } \\
\text { Consumer Services }\end{array}$ \\
\hline Bambauer-Sachse and Mangold & 2013 & $\begin{array}{l}\text { Do consumers still believe what is said in online product reviews? } \\
\text { A persuasion knowledge approach }\end{array}$ & $\begin{array}{l}\text { Journal of Retailing and } \\
\text { Consumer Services }\end{array}$ \\
\hline Bone, Fombelle, Ray, and Lemon & 2015 & $\begin{array}{l}\text { How Customer Participation in B2B Peer-to-Peer Problem-Solving } \\
\text { Communities Influences the Need for Traditional Customer Service }\end{array}$ & Journal of Service Research \\
\hline Cho & 2014 & $\begin{array}{l}\text { Service Quality and Price Perceptions by Internet Retail Customers: } \\
\text { Linking the Three Stages of Service Interaction }\end{array}$ & Journal of Service Research \\
\hline $\begin{array}{l}\text { Dholakia, Blazevic, Wiertz, and } \\
\text { Algesheimer }\end{array}$ & 2009 & $\begin{array}{l}\text { Communal Service Delivery How Customers Benefit from } \\
\text { Participation in Firm-Hosted Virtual P3 Communities }\end{array}$ & Journal of Service Research \\
\hline $\begin{array}{l}\text { Hennig-Thurau, Malthouse, Friege, } \\
\text { Gensler, Lobschat, Rangaswamy, and } \\
\text { Skiera }\end{array}$ & 2010 & The Impact of New Media on Customer Relationships & Journal of Service Research \\
\hline $\begin{array}{l}\text { Libai, Bolton, Bügel, De Ruyter, Gotz, } \\
\text { Risselada, and Stephen }\end{array}$ & 2010 & $\begin{array}{l}\text { Customer-to-Customer Interactions: Broadening the Scope of Word of } \\
\text { Mouth Research }\end{array}$ & Journal of Service Research \\
\hline $\begin{array}{l}\text { López-López, Ruiz-de-Maya, and } \\
\text { Warlop }\end{array}$ & 2014 & $\begin{array}{l}\text { When Sharing Consumption Emotions with Strangers Is More } \\
\text { Satisfying Than Sharing Them with Friends }\end{array}$ & Journal of Service Research \\
\hline Verhoef, Reinartz, and Krafft & 2010 & Customer Engagement as a New Perspective in Customer Management & Journal of Service Research \\
\hline Harwood and Garry & 2015 & $\begin{array}{l}\text { An investigation into gamification as a customer engagement } \\
\text { experience environment }\end{array}$ & Journal of Services Marketing \\
\hline Keeling, Khan, and Newholm & 2013 & Internet forums and negotiation of healthcare knowledge cultures & Journal of Services Marketing \\
\hline Magnini & 2011 & $\begin{array}{l}\text { The implications of company-sponsored messages disguised as word- } \\
\text { of-mouth }\end{array}$ & Journal of Services Marketing \\
\hline Ramanathan and Ramanathan & 2013 & $\begin{array}{l}\text { Investigating the impact of resource capabilities on customer loyalty: a } \\
\text { structural equation approach for the UK hotels using online ratings }\end{array}$ & Journal of Services Marketing \\
\hline Shen & 2014 & $\begin{array}{l}\text { Recommendations as personalized marketing: insights from customer } \\
\text { experiences }\end{array}$ & Journal of Services Marketing \\
\hline Tuzovic & 2010 & $\begin{array}{l}\text { Frequent (flier) frustration and the dark side of word-of-web: exploring } \\
\text { online dysfunctional behavior in online feedback forums }\end{array}$ & Journal of Services Marketing \\
\hline Yang, Peterson, and Cai & 2003 & $\begin{array}{l}\text { Services quality dimensions of Internet retailing: an exploratory } \\
\text { analysis }\end{array}$ & Journal of Services Marketing \\
\hline Choudhury and Harrigan & 2014 & $\begin{array}{l}\text { CRM to social CRM: the integration of new technologies into } \\
\text { customer relationship management }\end{array}$ & Journal of Strategic Marketing \\
\hline Huang, Zhang, Liu, and Liang & 2014 & $\begin{array}{l}\text { The effect of online and offline word-of-mouth on new product } \\
\text { diffusion }\end{array}$ & Journal of Strategic Marketing \\
\hline Poch and Martin & 2015 & Effects of intrinsic and extrinsic motivation on user-generated content & Journal of Strategic Marketing \\
\hline Roy, Butaney, Sekhon, and Butaney & 2014 & $\begin{array}{l}\text { Word-of-mouth and viral marketing activity of the on-line consumer: } \\
\text { the role of loyalty chain stages theory }\end{array}$ & Journal of Strategic Marketing \\
\hline Schau and Muniz & 2006 & A tale of tales: The Apple Newton narratives & Journal of Strategic Marketing \\
\hline Smith & 2011 & $\begin{array}{l}\text { Digital marketing strategies that Millennials find appealing, } \\
\text { motivating, or just annoying }\end{array}$ & Journal of Strategic Marketing \\
\hline Adjei, Noble, and Noble & 2010 & $\begin{array}{l}\text { The influence of C2C communications in online brand communities on } \\
\text { customer purchase behavior }\end{array}$ & $\begin{array}{l}\text { Journal of the Academy of } \\
\text { Marketing Science }\end{array}$ \\
\hline Beckers, Van Doorn, and Verhoef & 2018 & $\begin{array}{l}\text { Good, better, engaged? The effect of company-initiated customer } \\
\text { engagement behavior on shareholder value }\end{array}$ & $\begin{array}{l}\text { Journal of the Academy of } \\
\text { Marketing Science }\end{array}$ \\
\hline Gruner, Homburg, and Lukas & 2014 & Firm-hosted online brand communities and new product success & $\begin{array}{l}\text { Journal of the Academy of } \\
\text { Marketing Science }\end{array}$ \\
\hline Hanson, Jiang, and Dahl & 2019 & $\begin{array}{l}\text { Enhancing consumer engagement in an online brand community via } \\
\text { user reputation signals: A multi-method analysis }\end{array}$ & $\begin{array}{l}\text { Journal of the Academy of } \\
\text { Marketing Science }\end{array}$ \\
\hline Hennig-Thurau, Wiertz, and Feldhaus & 2015 & $\begin{array}{l}\text { Does Twitter Matter? An Investigation of the Impact of Microblogging } \\
\text { Word of Mouth on Consumers' Adoption of New Products }\end{array}$ & $\begin{array}{l}\text { Journal of the Academy of } \\
\text { Marketing Science }\end{array}$ \\
\hline $\begin{array}{l}\text { Motyka, Grewal, Aguirre, Mahr, De } \\
\text { Ruyter, and Wetzels }\end{array}$ & 2018 & $\begin{array}{l}\text { The Emotional Review-Reward Effect: How Do Reviews Increase } \\
\text { Impulsivity? }\end{array}$ & $\begin{array}{l}\text { Journal of the Academy of } \\
\text { Marketing Science }\end{array}$ \\
\hline Song, Moon, Chen, and Houston & 2017 & $\begin{array}{l}\text { When marketing strategy meets culture: the role of culture in product } \\
\text { evaluations }\end{array}$ & $\begin{array}{l}\text { Journal of the Academy of } \\
\text { Marketing Science }\end{array}$ \\
\hline Wilson, Giebelhausen, and Brady & 2017 & $\begin{array}{l}\text { Negative word of mouth can be a positive for consumers connected to } \\
\text { the brand }\end{array}$ & $\begin{array}{l}\text { Journal of the Academy of } \\
\text { Marketing Science }\end{array}$ \\
\hline $\begin{array}{l}\text { Kusumasondjaja, Shanka, and } \\
\text { Marchegiani }\end{array}$ & 2012 & $\begin{array}{l}\text { Credibility of online reviews and initial trust: The roles of reviewer's } \\
\text { identity and review valence }\end{array}$ & Journal of Vacation Marketing \\
\hline Cadario & 2013 & $\begin{array}{l}\text { The Impact of Online Word of Mouth on Television Show Viewership: } \\
\text { An Inverted U-Shaped Temporal Dynamic }\end{array}$ & Marketing Letters \\
\hline $\begin{array}{l}\text { Godes, Mayzlin, Chen, Das, Dellarocas, } \\
\text { Pfeiffer, Libai, Sen, Shi, and Verlegh }\end{array}$ & 2005 & The Firm's Management of Social Interactions & Marketing Letters \\
\hline $\begin{array}{l}\text { Hartmann, Manchanda, Nair, Bothner, } \\
\text { Dodds, Godes, Hosanagar, and } \\
\text { Tucker }\end{array}$ & 2008 & $\begin{array}{l}\text { Modeling social interactions: Identification, empirical methods and } \\
\text { policy implications }\end{array}$ & Marketing Letters \\
\hline Jang, Prasad, and Ratchford & 2012 & How consumers use product reviews in the purchase decision process & Marketing Letters \\
\hline Kim and Slotegraaf & 2015 & $\begin{array}{l}\text { Brand-embedded interaction: a dynamic and personalized interaction } \\
\text { for co-creation }\end{array}$ & Marketing Letters \\
\hline Kim, Naylor, Sivadas, and Sugumaran & 2016 & The unrealized value of incentivized eWOM recommendations & Marketing Letters \\
\hline $\begin{array}{l}\text { Lambrecht, Goldfarb, Bonatti, Ghose, } \\
\text { Goldstein, Lewis, Rao, Sahni, and Yao }\end{array}$ & 2014 & How do firms make money selling digital goods online? & Marketing Letters \\
\hline Lim, Al-Aali, and Heinrichs & 2015 & $\begin{array}{l}\text { Impact of satisfaction with e-retailers' touch points on purchase } \\
\text { behavior: the moderating effect of search and experience product type }\end{array}$ & Marketing Letters \\
\hline López-López and Ruiz-de-Maya & 2012 & When hedonic products help regulate my mood & Marketing Letters \\
\hline
\end{tabular}




\begin{tabular}{|c|c|c|c|}
\hline McAlister, Sonnier, and Shively & 2012 & The relationship between online chatter and firm value & Marketing Letters \\
\hline $\begin{array}{l}\text { Naik, Wedel, Bacon, Bodapati, Bradlow, } \\
\text { Kamakura, Kreulen, Lenk, Madigan, and } \\
\text { Montgomery }\end{array}$ & 2008 & Challenges and opportunities in high-dimensional choice data analyses & Marketing Letters \\
\hline 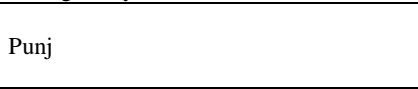 & 2013 & $\begin{array}{l}\text { Do consumers who conduct online research also post online reviews? } \\
\text { A model of the relationship between online research and review } \\
\text { posting behavior }\end{array}$ & Marketing Letters \\
\hline Shin, Song, and Biswas & 2014 & $\begin{array}{l}\text { Electronic word-of-mouth (eWOM) generation in new media } \\
\text { platforms: The role of regulatory focus and collective dissonance }\end{array}$ & Marketing Letters \\
\hline Tang and Guo & 2015 & $\begin{array}{l}\text { Digging for gold with a simple tool: Validating text mining in studying } \\
\text { electronic word-of-mouth (eWOM) communication }\end{array}$ & Marketing Letters \\
\hline Algesheimer, Borle, Dholakia, and Singh & 2010 & $\begin{array}{l}\text { The Impact of Customer Community Participation on Customer } \\
\text { Behaviors: An Empirical Investigation }\end{array}$ & Marketing Science \\
\hline $\begin{array}{l}\text { Chintagunta, Gopinath, and } \\
\text { Venkataraman }\end{array}$ & 2010 & $\begin{array}{l}\text { The Effects of Online User Reviews on Movie Box Office } \\
\text { Performance: Accounting for Sequential Rollout and Aggregation } \\
\text { Across Local Markets }\end{array}$ & Marketing Science \\
\hline Ghose, Ipeirotis, and $\mathrm{Li}$ & 2012 & $\begin{array}{l}\text { Designing Ranking Systems for Hotels on Travel Search Engines by } \\
\text { Mining User-Generated and Crowdsourced Content }\end{array}$ & Marketing Science \\
\hline Godes and Mayzlin & 2004 & Using Online Conversations to Study Word-of-Mouth Communication & Marketing Science \\
\hline Godes and Mayzlin & 2009 & $\begin{array}{l}\text { Firm-Created Word-of-Mouth Communication: Evidence from a Field } \\
\text { Test }\end{array}$ & Marketing Science \\
\hline Godes and Silva & 2012 & Sequential and Temporal Dynamics of Online Opinion & Marketing Science \\
\hline Gopinath, Thomas, and Krishnamurthi & 2014 & $\begin{array}{l}\text { Investigating the Relationship Between the Content of Online Word of } \\
\text { Mouth, Advertising, and Brand Performance }\end{array}$ & Marketing Science \\
\hline Jiang, Jerath, and Srinivasan & 2011 & Firm Strategies in the "Mid Tail” of Platform-Based Retailing & Marketing Science \\
\hline Kuksov and Xie & 2010 & Pricing, Frills, and Customer Ratings & Marketing Science \\
\hline Kuksov, Shachar, and Wang & 2013 & Advertising and Consumers' Communications & Marketing Science \\
\hline $\begin{array}{l}\text { Kumar, Bhaskaran, Mirchandani, and } \\
\text { Shah }\end{array}$ & 2013 & $\begin{array}{l}\text { Creating a Measurable Social Media Marketing Strategy: Increasing } \\
\text { the Value and ROI of Intangibles and Tangibles for Hokey Pokey }\end{array}$ & Marketing Science \\
\hline Ma, Sun, and Kekre & 2015 & $\begin{array}{l}\text { The Squeaky Wheel Gets the Grease-An Empirical Analysis of } \\
\text { Customer Voice and Firm Intervention on Twitter }\end{array}$ & Marketing Science \\
\hline Mayzlin & 2006 & Promotional Chat on the Internet & Marketing Science \\
\hline Moe and Schweidel & 2012 & Online Product Opinions: Incidence, Evaluation, and Evolution & Marketing Science \\
\hline $\begin{array}{l}\text { Netzer, Feldman, Goldenberg, and } \\
\text { Fresko }\end{array}$ & 2012 & $\begin{array}{l}\text { Mine Your Own Business: Market-Structure Surveillance Through } \\
\text { Text Mining }\end{array}$ & Marketing Science \\
\hline Singh, Hilmer, and Wang & 2011 & $\begin{array}{l}\text { Efficient Methods for Sampling Responses from Large-Scale } \\
\text { Qualitative Data }\end{array}$ & Marketing Science \\
\hline Sonnier, McAlister, and Rutz & 2011 & $\begin{array}{l}\text { A Dynamic Model of the Effect of Online Communications on Firm } \\
\text { Sales }\end{array}$ & Marketing Science \\
\hline Sun, Dong, and McIntyre & 2017 & $\begin{array}{l}\text { Motivation of user-generated content: Social connectedness moderates } \\
\text { the effects of monetary rewards }\end{array}$ & Marketing Science \\
\hline Timoshenko and Hauser & 2019 & Identifying Customer Needs from User-Generated Content & Marketing Science \\
\hline Tirunillai and Tellis & 2012 & $\begin{array}{l}\text { Does Chatter Really Matter? Dynamics of User-Generated Content and } \\
\text { Stock Performance }\end{array}$ & Marketing Science \\
\hline $\begin{array}{l}\text { Van Der Lans, Van Bruggen, Eliashberg, } \\
\text { and Wierenga }\end{array}$ & 2010 & $\begin{array}{l}\text { A Viral Branching Model for Predicting the Spread of Electronic Word } \\
\text { of Mouth }\end{array}$ & Marketing Science \\
\hline $\mathrm{Wu}$, Che, Chan, and $\mathrm{Lu}$ & 2015 & The Economic Value of Online Reviews & Marketing Science \\
\hline Xiong and Bharadwaj & 2014 & Prerelease Buzz Evolution Patterns and New Product Performance & Marketing Science \\
\hline Zeithammer and Adams & 2010 & The Sealed-Bid Abstraction in Online Auctions & Marketing Science \\
\hline Zhao, Yang, Narayan, and Zhao & 2013 & Modeling Consumer Learning from Online Product Reviews & Marketing Science \\
\hline Corciolani, Gistri, and Pace & 2016 & $\begin{array}{l}\text { Exploring the palm oil crisis through the lens of different social media: } \\
\text { An analysis of Facebook, YouTube, and Twitter contents }\end{array}$ & Mercati e Competitività \\
\hline Ashley and Tuten & 2015 & $\begin{array}{l}\text { Creative Strategies in Social Media Marketing: An Exploratory Study } \\
\text { of Branded Social Content and Consumer Engagement }\end{array}$ & Psychology and Marketing \\
\hline Badrinarayanan, Sierra, and Taute & 2014 & $\begin{array}{l}\text { Determinants and Outcomes of Online Brand Tribalism: Exploring } \\
\text { Communities of Massively Multiplayer Online Role-Playing Games } \\
\text { (MMORPGs) }\end{array}$ & Psychology and Marketing \\
\hline Balabanis and Chatzopolou & 2019 & $\begin{array}{l}\text { Under the influence of a blogger: The role of } \\
\text { information-seeking goals and issue involvement }\end{array}$ & Psychology and Marketing \\
\hline Berthon, Pitt, and Des Autels & 2011 & Unveiling Videos: Consumer-Generated Ads as Qualitative Inquiry & Psychology and Marketing \\
\hline Boon & 2013 & $\begin{array}{l}\text { A Qualitative Study of Consumer-Generated Videos about Daily Deal } \\
\text { Web sites }\end{array}$ & Psychology and Marketing \\
\hline Dinhopl, Gretzel, and Whelan & 2015 & Labeling as a Social Practice in Online Consumption Communities & Psychology and Marketing \\
\hline Gong and $\mathrm{Li}$ & 2017 & $\begin{array}{l}\text { Engaging fans on microblog: the synthetic influence of parasocial } \\
\text { interaction and source characteristics on celebrity endorsement }\end{array}$ & Psychology and Marketing \\
\hline Hall, Gough, and Seymour Smith & 2013 & Stake Management in Men’s Online Cosmetics Testimonials & Psychology and Marketing \\
\hline Hartmann, Wiertz, and Arnould & 2015 & $\begin{array}{l}\text { Exploring Consumptive Moments of Value-Creating Practice in } \\
\text { Online Community }\end{array}$ & Psychology and Marketing \\
\hline $\begin{array}{l}\text { Herrmann, Hildebrand, Sprott, and } \\
\text { Spangenberg }\end{array}$ & 2013 & $\begin{array}{l}\text { Option Framing and Product Feature Recommendations: Product } \\
\text { Configuration and Choice }\end{array}$ & Psychology and Marketing \\
\hline Huang and Chen & 2006 & Herding in Online Product Choice & Psychology and Marketing \\
\hline Husemann, Ladstaetter, and Luedicke & 2015 & $\begin{array}{l}\text { Conflict Culture and Conflict Management in Consumption } \\
\text { Communities }\end{array}$ & Psychology and Marketing \\
\hline Keeling, Laing, and Newholm & 2015 & $\begin{array}{l}\text { Health Communities as Permissible Space: Supporting Negotiation to } \\
\text { Balance Asymmetries }\end{array}$ & Psychology and Marketing \\
\hline Larson and Denton & 2014 & $\begin{array}{l}\text { eWOM Watchdogs: Ego-Threatening Product Domains and the } \\
\text { Policing of Positive Online Reviews }\end{array}$ & Psychology and Marketing \\
\hline März, Schubach, and Schumann & 2017 & $\begin{array}{l}\text { "Why Would I Read a Mobile Review?” Device Compatibility } \\
\text { Perceptions and Effects on Perceived Helpfulness }\end{array}$ & Psychology and Marketing \\
\hline $\begin{array}{l}\text { Meenaghan, McLoughlin, and } \\
\text { McCormack }\end{array}$ & 2013 & $\begin{array}{l}\text { New Challenges in Sponsorship Evaluation Actors, New Media, and } \\
\text { the Context of Praxis }\end{array}$ & Psychology and Marketing \\
\hline
\end{tabular}




\begin{tabular}{|c|c|c|c|}
\hline Megehee and Woodside & 2010 & $\begin{array}{l}\text { Creating visual narrative art for decoding stories that consumers and } \\
\text { brands tell }\end{array}$ & Psychology and Marketing \\
\hline O’Sullivan & 2015 & $\begin{array}{l}\text { The Market Maven Crowd: Collaborative Risk-Aversion and } \\
\text { Enhanced Consumption Context Control in an Illicit Market }\end{array}$ & Psychology and Marketing \\
\hline Park and Park & 2013 & $\begin{array}{l}\text { The Effect of Low- versus High-Variance in Product Reviews on } \\
\text { Product Evaluation }\end{array}$ & Psychology and Marketing \\
\hline Park, Shin, and Ju & 2015 & $\begin{array}{l}\text { A Taxonomy of Social Networking Site Users: Social Surveillance and } \\
\text { Self-surveillance Perspective }\end{array}$ & Psychology and Marketing \\
\hline Saenger, Thomas, and Johnson & 2013 & $\begin{array}{l}\text { Consumption-Focused Self-Expression Word of Mouth: A New Scale } \\
\text { and Its Role in Consumer Research }\end{array}$ & Psychology and Marketing \\
\hline Sibai, De Valck, Farrell, and Rudd & 2015 & $\begin{array}{l}\text { Social Control in Online Communities of Consumption: A Framework } \\
\text { for Community Management }\end{array}$ & Psychology and Marketing \\
\hline Steinmann, Mau, and Schramm-Klein & 2015 & $\begin{array}{l}\text { Brand Communication Success in Online Consumption Communities: } \\
\text { An Experimental Analysis of the Effects of Communication Style and } \\
\text { Brand Pictorial Representation }\end{array}$ & Psychology and Marketing \\
\hline Stokburger-Sauer & 2010 & Brand Community: Drivers and Outcomes & Psychology and Marketing \\
\hline Sweeney, Webb, Mazzarol, and Soutar & 2014 & $\begin{array}{l}\text { Self-Determination Theory and Word of Mouth about Energy-Saving } \\
\text { Behaviors: An Online Experiment }\end{array}$ & Psychology and Marketing \\
\hline $\begin{array}{l}\text { Teichmann, Stokburger-Sauer, Plank, } \\
\text { and Strobl }\end{array}$ & 2015 & $\begin{array}{l}\text { Motivational Drivers of Content Contribution to Company- Versus } \\
\text { Consumer-Hosted Online Communities }\end{array}$ & Psychology and Marketing \\
\hline Woodside, Sood, and Miller & 2008 & $\begin{array}{l}\text { When consumers and brands talk: Storytelling theory and research in } \\
\text { psychology and marketing }\end{array}$ & Psychology and Marketing \\
\hline Wu & 2013 & $\begin{array}{l}\text { In Search of Negativity Bias: An Empirical Study of Perceived } \\
\text { Helpfulness of Online Reviews }\end{array}$ & Psychology and Marketing \\
\hline Alon and Brunel & 2006 & $\begin{array}{l}\text { Uncovering Rhetorical Methods of Word-of-Mouth Talk in an Online } \\
\text { Community }\end{array}$ & Research in Consumer Behavior \\
\hline Bajde & 2013 & (Micro)Financing to Give: Kiva as a Gift-Market Hybrid & Research in Consumer Behavior \\
\hline Bradford, Grier, and Henderson & 2012 & Gifts and Gifting in Online Communities & Research in Consumer Behavior \\
\hline $\begin{array}{l}\text { Fyrberg-Yngfalk, Cova, Pace, and } \\
\text { Skalen }\end{array}$ & 2013 & $\begin{array}{l}\text { Control and Power in Online Consumer Tribes: The Role of } \\
\text { Confessions }\end{array}$ & Research in Consumer Behavior \\
\hline ( & 2011 & $\begin{array}{l}\text { Buying the Girlfriend Experience: An Exploration of the Consumption } \\
\text { Experiences of Male Customers of Escorts }\end{array}$ & Research in Consumer Behavior \\
\hline Kelleher, Whalley, and Helkkula & 2011 & $\begin{array}{l}\text { Collaborative Value Co-Creation in Crowd-Sourced Online } \\
\text { Communities - Acknowledging and Resolving Competing } \\
\text { Commercial and Communal Orientations }\end{array}$ & Research in Consumer Behavior \\
\hline Knudsen and Kjeldgaard & 2014 & $\begin{array}{l}\text { Online Reception Analysis: Big Data in Qualitative Marketing } \\
\text { Research }\end{array}$ & Research in Consumer Behavior \\
\hline Kretz and De Valck & 2010 & $\begin{array}{l}\text { "Pixelize me!": Digital storytelling and the creation of archetypal } \\
\text { myths through explicit and implicit self-brand association in fashion } \\
\text { and luxury blogs }\end{array}$ & Research in Consumer Behavior \\
\hline Lindblad and Ostberg & 2011 & $\begin{array}{l}\text { The Cultural Role of Stigmatized Youth Groups: The Case of the } \\
\text { Partille Johnnys of Sweden }\end{array}$ & Research in Consumer Behavior \\
\hline Schwob and De Valck & 2010 & $\begin{array}{l}\text { Better understanding construction of the self in daily contingencies: an } \\
\text { investigation of the materiality of consumption experiences in online } \\
\text { discussion forums }\end{array}$ & Research in Consumer Behavior \\
\hline Strandby and Askegaard & 2013 & Weddings as Waste & Research in Consumer Behavior \\
\hline Weijo and Rintamaki & 2014 & Hold the Line! Exploring the Brand Community Coping Process & Research in Consumer Behavior \\
\hline Hallier Willi, Melewar, and Broderick & 2013 & $\begin{array}{l}\text { Virtual brand-communities using blogs as communication platforms } \\
\text { and their impact on the two-step communication process: A research } \\
\text { agenda }\end{array}$ & The Marketing Review \\
\hline $\begin{array}{l}\text { Brett, Olekalns, Friedman, Goates, } \\
\text { Anderson, and Lisco }\end{array}$ & 2007 & Sticks and Stones: Language, Face, and Online Dispute Resolution & $\begin{array}{l}\text { Academy of Management } \\
\text { Journal }\end{array}$ \\
\hline Avery, Resnick, and Zeckhauser & 1999 & The Market for Evaluations & American Economic Review \\
\hline Chen, Harper, Konstan, and Li & 2010 & $\begin{array}{l}\text { Social Comparisons and Contributions to Online Communities: A } \\
\text { Field Experiment on MovieLens }\end{array}$ & American Economic Review \\
\hline Lewis & 2011 & $\begin{array}{l}\text { Asymmetric Information, Adverse Selection and Online Disclosure: } \\
\text { The Case of eBay Motors }\end{array}$ & American Economic Review \\
\hline Mayzlin, Dover, and Chevalier & 2014 & $\begin{array}{l}\text { Promotional Reviews: An Empirical Investigation of Online Review } \\
\text { Manipulation }\end{array}$ & American Economic Review \\
\hline Berthon, Pitt, and Campbell & 2008 & Ad Lib: When customers create the ad & California Management Review \\
\hline Brown and Morgan & 2006 & Reputation in Online Auctions: The Market for Trust & California Management Review \\
\hline Kolk, Lee, and Van Dolen & 2012 & A Fat Debate on Big Food? Unraveling blogosphere reactions & California Management Review \\
\hline Porter, Donthu, MacElroy, and Wydra & 2011 & How to Foster and Sustain Engagement in Virtual Communities & California Management Review \\
\hline Sicilia and Palazon & 2008 & $\begin{array}{l}\text { Brand communities on the internet: A case study of Coca-Cola's } \\
\text { Spanish virtual community }\end{array}$ & $\begin{array}{l}\text { Corporate Communications: An } \\
\text { International Journal }\end{array}$ \\
\hline Kozinets & 1999 & $\begin{array}{l}\text { E-Tribalized Marketing? The Strategic Implications of Virtual } \\
\text { Communities of Consumption }\end{array}$ & European Management Journal \\
\hline $\begin{array}{l}\text { Leeflang, Verhoef, Dahlstrom and } \\
\text { Freundt }\end{array}$ & 2014 & Challenges and solutions for marketing in a digital era & European Management Journal \\
\hline $\begin{array}{l}\text { Sabate, Berbegal-Mirabent, Canabate, } \\
\text { and Lebherz }\end{array}$ & 2014 & $\begin{array}{l}\text { Factors influencing popularity of branded content in Facebook fan } \\
\text { pages }\end{array}$ & European Management Journal \\
\hline Aral & 2013 & What Would Ashton Do- - and Does It Matter? & Harvard Business Review \\
\hline Ariely & 2007 & The Customers' Revenge & Harvard Business Review \\
\hline Armstrong and Hagel & 1996 & The real value of on-line communities & Harvard Business Review \\
\hline Barwise and Meehan & 2010 & The One Thing You Must Get Right When Building a Brand & Harvard Business Review \\
\hline Dholakia and Durham & 2010 & One Café Chain’s Facebook Experiment & Harvard Business Review \\
\hline Dye & 2000 & The Buzz on Buzz & Harvard Business Review \\
\hline Fournier and Lee & 2009 & Getting Brand Communities Right & Harvard Business Review \\
\hline Seijts & 2014 & When the Twitterverse Turns on You & Harvard Business Review \\
\hline Sevitt and Samuel & 2013 & How Pinterest Puts People in Stores & Harvard Business Review \\
\hline Simester & 2011 & When You Shouldn't Listen to Your Critics & Harvard Business Review \\
\hline
\end{tabular}




\begin{tabular}{|c|c|c|c|}
\hline Simonson and Rosen & 2014 & What Marketers Misunderstand About Online Reviews & Harvard Business Review \\
\hline Yang & 2018 & $\begin{array}{l}\text { More Is Less: Only Moderate Polarized Online Product Reviews Can } \\
\text { Affect Sales }\end{array}$ & $\begin{array}{l}\text { International Journal of } \\
\text { Business and Management }\end{array}$ \\
\hline Eberle, Berens, and Li & 2013 & $\begin{array}{l}\text { The Impact of Interactive Corporate Social Responsibility } \\
\text { Communication on Corporate Reputation }\end{array}$ & Journal of Business Ethics \\
\hline Gummerus, Liljander, and Sihlman & 2015 & $\begin{array}{l}\text { Do Ethical Social Media Communities Pay Off? An Exploratory Study } \\
\text { of the Ability of Facebook Ethical Communities to Strengthen } \\
\text { Consumers' Ethical Consumption Behavior }\end{array}$ & Journal of Business Ethics \\
\hline Lee, Van Dolen, and Kolk & 2013 & $\begin{array}{l}\text { On the Role of Social Media in the 'Responsible' Food Business: } \\
\text { Blogger Buzz on Health and Obesity Issues }\end{array}$ & Journal of Business Ethics \\
\hline Meza and Park & 2015 & Organic Products in Mexico and South Korea on Twitter & Journal of Business Ethics \\
\hline $\begin{array}{l}\text { Alves Leal, Hor-Meyll, and de Paula } \\
\text { Pessôa }\end{array}$ & 2014 & $\begin{array}{l}\text { Influence of virtual communities in purchasing decisions: The } \\
\text { participants' perspective }\end{array}$ & Journal of Business Research \\
\hline Baldus, Voorhees, and Calantone & 2015 & $\begin{array}{l}\text { Online brand community engagement: Scale development and } \\
\text { validation }\end{array}$ & Journal of Business Research \\
\hline Benedicktus & 2011 & $\begin{array}{l}\text { The effects of 3rd party consensus information on service expectations } \\
\text { and online trust }\end{array}$ & Journal of Business Research \\
\hline Bianchi and Andrews & 2015 & $\begin{array}{l}\text { Investigating marketing managers' perspectives on social media in } \\
\text { Chile }\end{array}$ & Journal of Business Research \\
\hline Braunsberger and Buckler & 2011 & $\begin{array}{l}\text { What motivates consumers to participate in boycotts: Lessons from the } \\
\text { ongoing Canadian seafood boycott }\end{array}$ & Journal of Business Research \\
\hline Brodie, Ilic, Juric, and Hollebeek & 2013 & $\begin{array}{l}\text { Consumer engagement in a virtual brand community: An exploratory } \\
\text { analysis }\end{array}$ & Journal of Business Research \\
\hline Capriello, Mason, Davis, and Crotts & 2013 & $\begin{array}{l}\text { Farm tourism experiences in travel reviews: A cross-comparison of } \\
\text { three alternative methods for data analysis }\end{array}$ & Journal of Business Research \\
\hline Chan and Li & 2013 & $\begin{array}{l}\text { Understanding consumer-to-consumer interactions in virtual } \\
\text { communities: The salience of reciprocity }\end{array}$ & Journal of Business Research \\
\hline Chang, Yu, and Lu & 2015 & $\begin{array}{l}\text { Persuasive messages, popularity cohesion, and message diffusion in } \\
\text { social media marketing }\end{array}$ & Journal of Business Research \\
\hline Cheng and Ho & 2015 & Social influence's impact on reader perceptions of online reviews & Journal of Business Research \\
\hline Chung & 2011 & $\begin{array}{l}\text { Investigating the roles of online buzz for new product diffusion and its } \\
\text { cross-country dynamics }\end{array}$ & Journal of Business Research \\
\hline Elliot, Li, and Choi & 2013 & $\begin{array}{l}\text { Understanding service quality in a virtual travel community } \\
\text { environment }\end{array}$ & Journal of Business Research \\
\hline Filieri & 2015 & $\begin{array}{l}\text { What makes online reviews helpful? A diagnosticity-adoption } \\
\text { framework to explain informational and normative influences in e- } \\
\text { WOM }\end{array}$ & Journal of Business Research \\
\hline Fong and Burton & 2008 & $\begin{array}{l}\text { A cross-cultural comparison of electronic word-of-mouth and country- } \\
\text { of-origin effects }\end{array}$ & Journal of Business Research \\
\hline Gebauer, Fueller, and Pezzei & 2013 & $\begin{array}{l}\text { The dark and the bright side of co-creation: Triggers of member } \\
\text { behavior in online innovation communities }\end{array}$ & Journal of Business Research \\
\hline Gruen, Osmonbekov, and Czaplewski & 2006 & $\begin{array}{l}\text { eWOM: The impact of customer-to-customer online know-how } \\
\text { exchange on customer value and loyalty }\end{array}$ & Journal of Business Research \\
\hline Gunawan and Huarng & 2015 & $\begin{array}{l}\text { Viral effects of social network and media on consumers' purchase } \\
\text { intention }\end{array}$ & Journal of Business Research \\
\hline Gupta and Harris & 2010 & $\begin{array}{l}\text { How e-WOM recommendations influence product consideration and } \\
\text { quality of choice: A motivation to process information perspective }\end{array}$ & Journal of Business Research \\
\hline $\begin{array}{l}\text { Hall-Phillips, Park, Chung, Anaza, and } \\
\text { Rathod }\end{array}$ & 2015 & I (heart) social ventures: Identification and social media engagement & Journal of Business Research \\
\hline Hamby, Daniloski, and Brinberg & 2015 & How consumer reviews persuade through narratives & Journal of Business Research \\
\hline Healy and McDonagh & 2013 & $\begin{array}{l}\text { Consumer roles in brand culture and value co-creation in virtual } \\
\text { communities }\end{array}$ & Journal of Business Research \\
\hline Hu, Liu, Tripathy, and Yao & 2011 & Value relevance of blog visibility & Journal of Business Research \\
\hline Jeong, Paek, and Lee & 2013 & Corporate social responsibility effects on social network sites & Journal of Business Research \\
\hline Kim and Gupta & 2012 & $\begin{array}{l}\text { Emotional expressions in online user reviews: How they influence } \\
\text { consumers' product evaluations }\end{array}$ & Journal of Business Research \\
\hline Kim and Ko & 2012 & $\begin{array}{l}\text { Do social media marketing activities enhance customer equity? An } \\
\text { empirical study of luxury fashion brand }\end{array}$ & Journal of Business Research \\
\hline Lee, Lee, Kim, and Lee & 2013 & $\begin{array}{l}\text { The moderating role of socio-semantic networks on online buzz } \\
\text { diffusion }\end{array}$ & Journal of Business Research \\
\hline Lin and Huang & 2006 & Internet blogs as a tourism marketing medium: A case study & Journal of Business Research \\
\hline Lin, $\mathrm{Wu}, \mathrm{Li}$, and Cheng & 2015 & A fair reputation system for use in online auctions & Journal of Business Research \\
\hline Manes and Tchetchik & 2018 & $\begin{array}{l}\text { The role of electronic word of mouth in reducing information } \\
\text { asymmetry: An empirical investigation of online hotel booking }\end{array}$ & Journal of Business Research \\
\hline Martin and Lueg & 2013 & Modeling word-of-mouth usage & Journal of Business Research \\
\hline Megehee and Spake & 2012 & Consumer enactments of archetypes using luxury brands & Journal of Business Research \\
\hline Nambisan and Watt & 2011 & Managing customer experiences in online product communities & Journal of Business Research \\
\hline Nelson and Otnes & 2005 & $\begin{array}{l}\text { Exploring cross-cultural ambivalence: a netnography of intercultural } \\
\text { wedding message boards }\end{array}$ & Journal of Business Research \\
\hline Park and Lee & 2009 & $\begin{array}{l}\text { Information direction, website reputation and eWOM effect: A } \\
\text { moderating role of product type }\end{array}$ & Journal of Business Research \\
\hline Raïes, Mühlbacher, and Gavard-Perret & 2015 & $\begin{array}{l}\text { Consumption community commitment: Newbies' and longstanding } \\
\text { members' brand engagement and loyalty }\end{array}$ & Journal of Business Research \\
\hline Townsend, Neal, and Morgan & 2019 & $\begin{array}{l}\text { The impact of the mere presence of social media share icons on } \\
\text { product interest and valuation }\end{array}$ & Journal of Business Research \\
\hline Tsang and Zhou & 2005 & $\begin{array}{l}\text { Newsgroup participants as opinion leaders and seekers in online and } \\
\text { offline communication environments }\end{array}$ & Journal of Business Research \\
\hline Vallaster and Von Wallpach & 2013 & $\begin{array}{l}\text { An online discursive inquiry into the social dynamics of multi- } \\
\text { stakeholder brand meaning co-creation }\end{array}$ & Journal of Business Research \\
\hline Wang, Ting, and Wu & 2013 & $\begin{array}{l}\text { Discovering interest groups for marketing in virtual communities: An } \\
\text { integrated approach }\end{array}$ & Journal of Business Research \\
\hline
\end{tabular}




\begin{tabular}{|c|c|c|c|}
\hline Weijo, Hietanen, and Mattila & 2014 & New insights into online consumption communities and netnography & Journal of Business Research \\
\hline Weinberg and Davis & 2005 & Exploring the WOW in online-auction feedback & Journal of Business Research \\
\hline $\mathrm{Wu}$ & 2015 & $\begin{array}{l}\text { Facebook users' intentions in risk communication and food-safety } \\
\text { issues }\end{array}$ & Journal of Business Research \\
\hline Wu, Chen, Chen, and Cheng & 2014 & $\begin{array}{l}\text { Perceived value, transaction cost, and repurchase-intention in online } \\
\text { shopping: A relational exchange perspective }\end{array}$ & Journal of Business Research \\
\hline Yang and Mai & 2010 & $\begin{array}{l}\text { Experiential goods with network externalities effects: An empirical } \\
\text { study of online rating system }\end{array}$ & Journal of Business Research \\
\hline Zaglia & 2013 & Brand communities embedded in social networks & Journal of Business Research \\
\hline Zhang, Craciun, and Shin & 2010 & $\begin{array}{l}\text { When does electronic word-of-mouth matter? A study of consumer } \\
\text { product reviews }\end{array}$ & Journal of Business Research \\
\hline Zhou, Zhang, Su, and Zhou & 2012 & $\begin{array}{l}\text { How do brand communities generate brand relationships? Intermediate } \\
\text { mechanisms }\end{array}$ & Journal of Business Research \\
\hline Aperjis and Johari & 2010 & Optimal Windows for Aggregating Ratings in Electronic Marketplaces & Management Science \\
\hline Aral and Walker & 2011 & $\begin{array}{l}\text { Creating Social Contagion Through Viral Product Design: A } \\
\text { Randomized Trial of Peer Influence in Networks }\end{array}$ & Management Science \\
\hline Archak, Ghose, and Ipeirotis & 2011 & $\begin{array}{l}\text { Deriving the Pricing Power of Product Features by Mining Consumer } \\
\text { Reviews }\end{array}$ & Management Science \\
\hline Chen and Xie & 2008 & $\begin{array}{l}\text { Online Consumer Review: Word-of-Mouth as a New Element of } \\
\text { Marketing Communication Mix }\end{array}$ & Management Science \\
\hline Choi, Bell, and Lodish & 2012 & Traditional and IS-Enabled Customer Acquisition on the Internet & Management Science \\
\hline Das and Chen & 2007 & Yahoo! For Amazon: Sentiment extraction from small talk on the web & Management Science \\
\hline Dellarocas & 2003 & $\begin{array}{l}\text { The Digitization of Word of Mouth: Promise and Challenges of Online } \\
\text { Feedback Mechanisms }\end{array}$ & Management Science \\
\hline Dellarocas & 2006 & $\begin{array}{l}\text { Strategic Manipulation of Internet Opinion Forums: Implications for } \\
\text { Consumers and Firms }\end{array}$ & Management Science \\
\hline Dellarocas and Wood & 2008 & $\begin{array}{l}\text { The Sound of Silence in Online Feedback: Estimating Trading Risks in } \\
\text { the Presence of Reporting Bias }\end{array}$ & Management Science \\
\hline Ghose, Ipeirotis, and Li & 2014 & $\begin{array}{l}\text { Examining the Impact of Ranking on Consumer Behavior and Search } \\
\text { Engine Revenue }\end{array}$ & Management Science \\
\hline $\begin{array}{l}\text { Gopinath, Chintagunta, and } \\
\text { Venkataraman }\end{array}$ & 2013 & Blogs, Advertising, and Local-Market Movie Box-Office Performance & Management Science \\
\hline Lee, Hosanagar, and Tan & 2015 & $\begin{array}{l}\text { Do I Follow My Friends or the Crowd? Information Cascades in } \\
\text { Online Movie Ratings }\end{array}$ & Management Science \\
\hline Lehman, Kovács, and Carroll & 2014 & $\begin{array}{l}\text { Conflicting Social Codes and Organizations: Hygiene and Authenticity } \\
\text { in Consumer Evaluations of Restaurant }\end{array}$ & Management Science \\
\hline Lu, Jerath, and Singh & 2014 & $\begin{array}{l}\text { The Emergence of Opinion Leaders in a Networked Online } \\
\text { Community: A Dyadic Model with Time Dynamics and a Heuristic for } \\
\text { Fast Estimation }\end{array}$ & Management Science \\
\hline Porter and Donthu & 2008 & Cultivating Trust and Harvesting Value in Virtual Communities & Management Science \\
\hline Shriver, Nair, and Hofstetter & 2013 & $\begin{array}{l}\text { Social Ties and User-Generated Content: Evidence from an Online } \\
\text { Social Network }\end{array}$ & Management Science \\
\hline Sun & 2012 & How Does the Variance of Product Ratings Matter? & Management Science \\
\hline Ba and Pavlou & 2002 & $\begin{array}{l}\text { Evidence of the effect of trust building technology in electronic } \\
\text { markets: price premiums and buyer behavior }\end{array}$ & MIS Quarterly \\
\hline Chau and $\mathrm{Xu}$ & 2012 & $\begin{array}{l}\text { Business intelligence in blogs: understanding consumer interactions } \\
\text { and communities }\end{array}$ & MIS Quarterly \\
\hline Dewan and Ramaprasad & 2014 & Social media, traditional media, and music sales & MIS Quarterly \\
\hline Duan, Gu, and Whinston & 2009 & $\begin{array}{l}\text { Informational cascades and software adoption on the internet: an } \\
\text { empirical investigation }\end{array}$ & MIS Quarterly \\
\hline Ghose & 2009 & $\begin{array}{l}\text { Internet exchanges for used goods: an empirical analysis of trade } \\
\text { patterns and adverse selection }\end{array}$ & MIS Quarterly \\
\hline Jabr and Zheng & 2014 & $\begin{array}{l}\text { Know yourself and know your enemy: an analysis of firm } \\
\text { recommendations and consumer reviews in a competitive environment }\end{array}$ & MIS Quarterly \\
\hline $\mathrm{Li}$ and Hitt & 2010 & $\begin{array}{l}\text { Price effects in online product reviews: an analytical model and } \\
\text { empirical analysis }\end{array}$ & MIS Quarterly \\
\hline $\begin{array}{l}\text { Ludwig, De Ruyter, Mahr, Wetzels, } \\
\text { Brüggen, and De Ruyck }\end{array}$ & 2014 & $\begin{array}{l}\text { Take their word for it: the symbolic role of linguistic style matches in } \\
\text { user communities }\end{array}$ & MIS Quarterly \\
\hline Mudambi and Schuff & 2010 & $\begin{array}{l}\text { What makes a helpful online review? A study of customer reviews on } \\
\text { amazon.com }\end{array}$ & MIS Quarterly \\
\hline Oestreicher-Singer and Zalmanson & 2013 & $\begin{array}{l}\text { Content or community? A digital business strategy for content } \\
\text { providers in the social age }\end{array}$ & MIS Quarterly \\
\hline Orlikowski and Scott & 2015 & $\begin{array}{l}\text { The algorithm and the crowd: considering the materiality of service } \\
\text { innovation }\end{array}$ & MIS Quarterly \\
\hline Ou, Pavlou, and Davison & 2014 & $\begin{array}{l}\text { Swift guanxi in online marketplaces: the role of computer-mediated } \\
\text { communication technologies }\end{array}$ & MIS Quarterly \\
\hline $\begin{array}{l}\text { Ren, Harper, Drenner, Terveen, Kiesler, } \\
\text { Riedl, and Kraut }\end{array}$ & 2012 & $\begin{array}{l}\text { Building member attachment in online communities: applying theories } \\
\text { of group identity and interpersonal bonds }\end{array}$ & MIS Quarterly \\
\hline Sahoo, Singh, and Mukhopadhyay & 2012 & A hidden Markov model for collaborative filtering & MIS Quarterly \\
\hline Scott and Orlikowski & 2014 & $\begin{array}{l}\text { Entanglements in practice: performing anonymity through social } \\
\text { media }\end{array}$ & MIS Quarterly \\
\hline Ye, Gao, and Viswanathan & 2014 & $\begin{array}{l}\text { Strategic behavior in online reputation systems: evidence from } \\
\text { revoking on ebay }\end{array}$ & MIS Quarterly \\
\hline Yin, Bond, and Zhang & 2014 & $\begin{array}{l}\text { Anxious or Angry? Effects of Discrete Emotions on the Perceived } \\
\text { Helpfulness of Online Reviews }\end{array}$ & MIS Quarterly \\
\hline Gallaugher and Ransbotham & 2010 & Social Media and Customer Dialog Management at Starbucks & MIS Quarterly Executive \\
\hline Hansen and Sia & 2015 & $\begin{array}{l}\text { Hummel's Digital Transformation Toward Omnichannel Retailing: } \\
\text { Key Lessons Learned }\end{array}$ & MIS Quarterly Executive \\
\hline Mandviwalla and Watson & 2014 & Generating Capital from Social Media & MIS Quarterly Executive \\
\hline Piccoli and Ott & 2014 & Impact of Mobility and Timing on User-Generated Content & MIS Quarterly Executive \\
\hline
\end{tabular}




\begin{tabular}{|c|c|c|c|}
\hline Dellarocas & 2010 & $\begin{array}{l}\text { Online Reputation Systems: How to Design One That Does What You } \\
\text { Need }\end{array}$ & MIT Sloan \\
\hline Fradkin, Grewal, and Holz & 2018 & $\begin{array}{l}\text { The Determinants of Online Review Informativeness: Evidence from } \\
\text { Field Experiments on Airbnb }\end{array}$ & MIT Sloan \\
\hline Hoffman and Fodor & 2010 & Can You Measure the ROI of Your Social Media Marketing & MIT Sloan \\
\hline Malhotra, Kubowicz Malhotra, and See & 2012 & How to Get Your Messages Retweeted & MIT Sloan \\
\hline Malhotra, Kubowicz Malhotra, and See & 2013 & How to Create Brand Engagement on Facebook & MIT Sloan \\
\hline McWilliam & 2000 & Building stronger brands through online communities & MIT Sloan \\
\hline Tripp and Gregoire & 2011 & When Unhappy Customers Strike Back on the Internet & MIT Sloan \\
\hline Miller, Fabian, and Lin & 2009 & Strategies for online communities & Strategic Management Journal \\
\hline Kim, Sung, and Kang & 2014 & $\begin{array}{l}\text { Brand followers' retweeting behavior on Twitter: How brand } \\
\text { relationships influence brand electronic word-of-mouth }\end{array}$ & Computers in Human Behavior \\
\hline Luan, Shan, Wang, and Xiao & 2019 & $\begin{array}{l}\text { How easy-to-process information influences consumers over time: } \\
\text { Online review vs. brand popularity }\end{array}$ & Computers in Human Behavior \\
\hline Ye, Law, Gu, and Chen & 2011 & $\begin{array}{l}\text { The influence of user-generated content on traveler behavior: An } \\
\text { empirical investigation on the effects of e-word-of-mouth to hotel } \\
\text { online bookings }\end{array}$ & Computers in Human Behavior \\
\hline Abrahams, Jiao, Fan, Wang, and Zhang & 2013 & $\begin{array}{l}\text { What's buzzing in the blizzard of buzz? Automotive component } \\
\text { isolation in social media postings }\end{array}$ & Decision Support Systems \\
\hline Abrahams, Jiao, Wang, and Fan & 2012 & Vehicle defect discovery from social media & Decision Support Systems \\
\hline Ba and Wang & 2013 & Digital health communities: The effect of their motivation mechanisms & Decision Support Systems \\
\hline Bai & 2011 & Predicting consumer sentiments from online text & Decision Support Systems \\
\hline Bao and Chang & 2014 & $\begin{array}{l}\text { Finding disseminators via electronic word of mouth message for } \\
\text { effective marketing communications }\end{array}$ & Decision Support Systems \\
\hline Bao and Chang & 2014 & $\begin{array}{l}\text { Why Amazon uses both the New York Times Best Seller List and } \\
\text { customer reviews: An empirical study of multiplier effects on product } \\
\text { sales from multiple earned media }\end{array}$ & Decision Support Systems \\
\hline Bauer and Nanopoulos & 2014 & $\begin{array}{l}\text { Recommender systems based on quantitative implicit customer } \\
\text { feedback }\end{array}$ & Decision Support Systems \\
\hline Bock, Lee, Kuan, and Kim & 2012 & $\begin{array}{l}\text { The progression of online trust in the multi-channel retailer context } \\
\text { and the role of product uncertainty }\end{array}$ & Decision Support Systems \\
\hline Cai, Lau, Liao, Li, Leung, and Ma & 2014 & Object typicality for effective Web of Things recommendations & Decision Support Systems \\
\hline Cao, Duan, and Gan & 2011 & $\begin{array}{l}\text { Exploring determinants of voting for the "helpfulness" of online user } \\
\text { reviews: A text mining approach }\end{array}$ & Decision Support Systems \\
\hline Castillo, Meer, and Castellanos & 2018 & $\begin{array}{l}\text { ExUP recommendations: Inferring user's product metadata preferences } \\
\text { from single-criterion rating systems }\end{array}$ & Decision Support Systems \\
\hline Chang, Tsai, Wong, Wang, and Cho & 2015 & $\begin{array}{l}\text { The effects of response strategies and severity of failure on consumer } \\
\text { attribution with regard to negative word-of-mouth }\end{array}$ & Decision Support Systems \\
\hline Cheung and Lee & 2012 & $\begin{array}{l}\text { What drives consumers to spread electronic word of mouth in online } \\
\text { consumer-opinion platforms }\end{array}$ & Decision Support Systems \\
\hline Cheung and Thadani & 2012 & $\begin{array}{l}\text { The impact of electronic word-of-mouth communication: A literature } \\
\text { analysis and integrative model }\end{array}$ & Decision Support Systems \\
\hline Cheung, Xiao, and Liu & 2014 & $\begin{array}{l}\text { Do actions speak louder than voices? The signaling role of social } \\
\text { information cues in influencing consumer purchase decisions }\end{array}$ & Decision Support Systems \\
\hline De Valck, Van Bruggen, and Wierenga & 2009 & Virtual communities: A marketing perspective & Decision Support Systems \\
\hline Du, Huang, and Li & 2013 & $\begin{array}{l}\text { Can online trading survive bad-mouthing? An experimental } \\
\text { investigation }\end{array}$ & Decision Support Systems \\
\hline Duan, Gu, and Whinston & 2008 & Do online reviews matter?-An empirical investigation of panel data & Decision Support Systems \\
\hline Fang, Guo, and Zhang & 2015 & Multi-faceted trust and distrust prediction for recommender systems & Decision Support Systems \\
\hline Gao, Hu, and Bose & 2016 & $\begin{array}{l}\text { Follow the herd or be myself? An analysis of consistency in behavior } \\
\text { of reviewers and helpfulness of their reviews }\end{array}$ & Decision Support Systems \\
\hline Garfinkel, Gopal, Pathak, and Yin & 2008 & $\begin{array}{l}\text { Shopbot 2.0: Integrating recommendations and promotions with } \\
\text { comparison shopping }\end{array}$ & Decision Support Systems \\
\hline Goes, Tu, and Tung & 2013 & $\begin{array}{l}\text { Seller heterogeneity in electronic marketplaces: A study of new and } \\
\text { experienced sellers in eBay }\end{array}$ & Decision Support Systems \\
\hline Gu, Tang, and Whinston & 2013 & The influence of online word-of-mouth on long tail formation & Decision Support Systems \\
\hline Guo & 2012 & Optimal decision making for online referral marketing & Decision Support Systems \\
\hline Han, Wang, Crespi, Park, and Cuevas & 2015 & $\begin{array}{l}\text { Alike people, alike interests? Inferring interest similarity in online } \\
\text { social networks }\end{array}$ & Decision Support Systems \\
\hline Ho, Damien, Gu, and Konana & 2017 & $\begin{array}{l}\text { The time-varying nature of social media sentiments in modeling stock } \\
\text { returns }\end{array}$ & Decision Support Systems \\
\hline Hong, Xu, Wang, and Fan & 2017 & $\begin{array}{l}\text { Understanding the determinants of online review helpfulness: A meta- } \\
\text { analytic investigation }\end{array}$ & Decision Support Systems \\
\hline $\mathrm{Hu}$, Bose, Gao, and Liu & 2011 & $\begin{array}{l}\text { Manipulation in digital word-of-mouth: A reality check for book } \\
\text { reviews }\end{array}$ & Decision Support Systems \\
\hline $\mathrm{Hu}$, Bose, Koh, and Liu & 2012 & $\begin{array}{l}\text { Manipulation of online reviews: An analysis of ratings, readability, } \\
\text { and sentiments }\end{array}$ & Decision Support Systems \\
\hline Hu, Koh, and Reddy & 2014 & $\begin{array}{l}\text { Ratings lead you to the product, reviews help you clinch it? The } \\
\text { mediating role of online review sentiments on product sales }\end{array}$ & Decision Support Systems \\
\hline Hu, Liu, and Sambamurthy & 2011 & Fraud detection in online consumer reviews & Decision Support Systems \\
\hline Jiang, Chen, Nunamaker, and Zimbra & 2014 & $\begin{array}{l}\text { Analyzing firm-specific social media and market: A stakeholder-based } \\
\text { event analysis framework }\end{array}$ & Decision Support Systems \\
\hline Josang, Ismail, and Boyd & 2007 & A survey of trust and reputation systems for online service provision & Decision Support Systems \\
\hline Klang & 2001 & Who do you trust? Beyond encryption, secure e-business & Decision Support Systems \\
\hline $\mathrm{Ku}$, Wei, and Hsiao & 2012 & $\begin{array}{l}\text { To whom should I listen? Finding reputable reviewers in opinion- } \\
\text { sharing communities }\end{array}$ & Decision Support Systems \\
\hline Lau, Li, and Liao & 2014 & $\begin{array}{l}\text { Social analytics: Learning fuzzy product ontologies for aspect-oriented } \\
\text { sentiment analysis }\end{array}$ & Decision Support Systems \\
\hline Lee, Lee, and Shin & 2011 & $\begin{array}{l}\text { The long tail or the short tail: The category-specific impact of eWOM } \\
\text { on sales distribution }\end{array}$ & Decision Support Systems \\
\hline Lee, Yang, Tsai, and Lai & 2014 & Discovering content-based behavioral roles in social networks & Decision Support Systems \\
\hline
\end{tabular}




\begin{tabular}{|c|c|c|c|}
\hline $\mathrm{Li}$ and $\mathrm{Du}$ & 2011 & $\begin{array}{l}\text { Who is talking? An ontology-based opinion leader identification } \\
\text { framework for word-of-mouth marketing in online social blogs }\end{array}$ & Decision Support Systems \\
\hline $\mathrm{Li}$ and $\mathrm{Du}$ & 2014 & Listen to me - Evaluating the influence of micro-blogs & Decision Support Systems \\
\hline Li and Lai & 2014 & $\begin{array}{l}\text { A social appraisal mechanism for online purchase decision support in } \\
\text { the micro-blogosphere }\end{array}$ & Decision Support Systems \\
\hline $\mathrm{Li}$ and $\mathrm{Li}$ & 2013 & Deriving market intelligence from microblogs & Decision Support Systems \\
\hline Li and Shiu & 2012 & A diffusion mechanism for social advertising over microblogs & Decision Support Systems \\
\hline $\mathrm{Li}$ and $\mathrm{Wu}$ & 2010 & $\begin{array}{l}\text { Using text mining and sentiment analysis for online forums hotspot } \\
\text { detection and forecast }\end{array}$ & Decision Support Systems \\
\hline Li, Chen, Liou, and Lin & 2014 & Creating social intelligence for product portfolio design & Decision Support Systems \\
\hline Li, Wang, and Liang & 2014 & $\begin{array}{l}\text { A multi-theoretical kernel-based approach to social network-based } \\
\text { recommendation }\end{array}$ & Decision Support Systems \\
\hline Lin & 2014 & $\begin{array}{l}\text { An empirical investigation of user and system recommendations in e- } \\
\text { commerce }\end{array}$ & Decision Support Systems \\
\hline Liu, Wu, and Liu & 2013 & $\begin{array}{l}\text { Bayesian Probabilistic Matrix Factorization with Social Relations and } \\
\text { Item Contents for Recommendation }\end{array}$ & Decision Support Systems \\
\hline Luo, Luo, Schatzberg, and Sia & 2013 & $\begin{array}{l}\text { Impact of informational factors on online recommendation credibility: } \\
\text { The moderating role of source credibility }\end{array}$ & Decision Support Systems \\
\hline Ngo-Ye and Sinha & 2014 & $\begin{array}{l}\text { The influence of reviewer engagement characteristics on online review } \\
\text { helpfulness: A text regression model }\end{array}$ & Decision Support Systems \\
\hline O’Leary & 2011 & $\begin{array}{l}\text { Blog mining-review and extensions: "From each according to his } \\
\text { opinion” }\end{array}$ & Decision Support Systems \\
\hline Piramuthu, Kapoor, Zhou, and Mauw & 2012 & Input online review data and related bias in recommender systems & Decision Support Systems \\
\hline Qiu, Pang, and Lim & 2012 & $\begin{array}{l}\text { Effects of conflicting aggregated rating on eWOM review credibility } \\
\text { and diagnosticity: The moderating role of review valence }\end{array}$ & Decision Support Systems \\
\hline Qu, Zhang, and Li & 2008 & $\begin{array}{l}\text { Determinants of online merchant rating: Content analysis of consumer } \\
\text { comments about Yahoo merchants }\end{array}$ & Decision Support Systems \\
\hline Reyes and Rosso & 2012 & $\begin{array}{l}\text { Making objective decisions from subjective data: Detecting irony in } \\
\text { customer reviews }\end{array}$ & Decision Support Systems \\
\hline Rui, Liu, and Whinston & 2013 & $\begin{array}{l}\text { Whose and What Chatter Matters? The Effect of Tweets on Movie } \\
\text { Sales }\end{array}$ & Decision Support Systems \\
\hline Sadovykh, Sundaram, and Piramuthu & 2015 & Do online social networks support decision-making? & Decision Support Systems \\
\hline Sadovykh, Sundaram, and Piramuthu & 2015 & $\begin{array}{l}\text { Do decision-making structure and sequence exist in health online } \\
\text { social networks? }\end{array}$ & Decision Support Systems \\
\hline Siering, Muntermann, and Rajagopalan & 2018 & $\begin{array}{l}\text { Explaining and predicting online review helpfulness: The role of } \\
\text { content and reviewer-related signals }\end{array}$ & Decision Support Systems \\
\hline Van Dam and Van de Velden & 2015 & Online profiling and clustering of Facebook users & Decision Support Systems \\
\hline Vandic, Van Dam, and Frasincar & 2012 & Faceted product search powered by the Semantic Web & Decision Support Systems \\
\hline Wang, Shen, and Sun & 2013 & $\begin{array}{l}\text { Transition of electronic word-of-mouth services from web to mobile } \\
\text { context: A trust transfer perspective }\end{array}$ & Decision Support Systems \\
\hline Wang, Sun, $\mathrm{Ma}, \mathrm{Xu}$, and $\mathrm{Gu}$ & 2014 & Sentiment classification: The contribution of ensemble learning & Decision Support Systems \\
\hline Wang, Wang, Fang, and Chau & 2013 & Store survival in online marketplace: An empirical investigation & Decision Support Systems \\
\hline Wijnhoven and Bloemen & 2014 & $\begin{array}{l}\text { External validity of sentiment mining reports: Can current methods } \\
\text { identify demographic biases, event biases, and manipulation of } \\
\text { reviews? }\end{array}$ & Decision Support Systems \\
\hline Wu, Huang, Song, and Liu & 2016 & $\begin{array}{l}\text { Towards building a high-quality microblog-specific Chinese sentiment } \\
\text { lexicon }\end{array}$ & Decision Support Systems \\
\hline $\mathrm{Wu}, \mathrm{Wu}$, Sun, and Yang & 2013 & $\begin{array}{l}\text { User reviews and uncertainty assessment: A two stage model of } \\
\text { consumers' willingness-to-pay in online markets }\end{array}$ & Decision Support Systems \\
\hline $\mathrm{Xu}$, Chen, and Santhanam & 2015 & $\begin{array}{l}\text { Will video be the next generation of e-commerce product reviews? } \\
\text { Presentation format and the role of product type }\end{array}$ & Decision Support Systems \\
\hline $\mathrm{Xu}$, Liao, Li, and Song & 2011 & $\begin{array}{l}\text { Mining comparative opinions from customer reviews for Competitive } \\
\text { Intelligence }\end{array}$ & Decision Support Systems \\
\hline Yang, Hu, and Zhang & 2007 & $\begin{array}{l}\text { Effects of a reputation feedback system on an online consumer-to- } \\
\text { consumer auction market }\end{array}$ & Decision Support Systems \\
\hline Ye, Cheng, and Fang & 2013 & $\begin{array}{l}\text { Learning from other buyers: The effect of purchase history records in } \\
\text { online marketplaces }\end{array}$ & Decision Support Systems \\
\hline Yoo, Sanders, and Moon & 2013 & $\begin{array}{l}\text { Exploring the effect of e-WOM participation on e-Loyalty in e- } \\
\text { commerce }\end{array}$ & Decision Support Systems \\
\hline Yu, Duan, and Cao & 2013 & $\begin{array}{l}\text { The impact of social and conventional media on firm equity value: A } \\
\text { sentiment analysis approach }\end{array}$ & Decision Support Systems \\
\hline Yu, Shen, Miao, An, and Leung & 2014 & Filtering trust opinions through reinforcement learning & Decision Support Systems \\
\hline Zadeh and Sharda & 2014 & Modeling brand post popularity dynamics in online social networks & Decision Support Systems \\
\hline Zhang, Prater, and Lipkin & 2013 & $\begin{array}{l}\text { Feedback reviews and bidding in online auctions: An integrated } \\
\text { hedonic regression and fuzzy logic expert system approach }\end{array}$ & Decision Support Systems \\
\hline Zhang, Zhao, Cheung, and Lee & 2014 & $\begin{array}{l}\text { Examining the influence of online reviews on consumers' decision- } \\
\text { making: A heuristic-systematic model }\end{array}$ & Decision Support Systems \\
\hline Zheng, Zhu, and Lin & 2013 & $\begin{array}{l}\text { Capturing the essence of word-of-mouth for social commerce: } \\
\text { Assessing the quality of online e-commerce reviews by a semi- } \\
\text { supervised approach }\end{array}$ & Decision Support Systems \\
\hline Ziegler and Golbeck & 2007 & Investigating interactions of trust and interest similarity & Decision Support Systems \\
\hline Zimbra, Saranges, Jindal & 2017 & $\begin{array}{l}\text { Movie Aspects, Tweet Metrics, and Movie Revenues: The Influence of } \\
\text { iOS vs. Android }\end{array}$ & Decision Support Systems \\
\hline Bae and Lee & 2011 & $\begin{array}{l}\text { Gender differences in consumers’ perception of online consumer } \\
\text { reviews }\end{array}$ & Electronic Commerce Research \\
\hline Tsao and Hsieh & 2015 & $\begin{array}{l}\text { eWOM persuasiveness: do eWOM platforms } \\
\text { and product type matter? }\end{array}$ & Electronic Commerce Research \\
\hline Wang, Wang, and Yao & 2019 & $\begin{array}{l}\text { What makes a helpful online review? A meta-analysis of review } \\
\text { characteristics }\end{array}$ & Electronic Commerce Research \\
\hline Chang and Wong & 2010 & $\begin{array}{l}\text { Selecting appropriate sellers in online auctions through a multi- } \\
\text { attribute reputation calculation method }\end{array}$ & $\begin{array}{l}\text { Electronic Commerce Research } \\
\text { and Applications }\end{array}$ \\
\hline
\end{tabular}




\begin{tabular}{|c|c|c|c|}
\hline Chen, Kou, Shang, and Chen & 2014 & $\begin{array}{l}\text { Visualizing market structure through online product reviews: Integrate } \\
\text { topic modeling, TOPSIS, and multi-dimensional scaling approaches }\end{array}$ & $\begin{array}{l}\text { Electronic Commerce Research } \\
\text { and Applications }\end{array}$ \\
\hline Chen, Tang, Wu, and Jheng & 2014 & $\begin{array}{l}\text { Predicting the influence of users' posted information for eWOM } \\
\text { advertising in social networks }\end{array}$ & $\begin{array}{l}\text { Electronic Commerce Research } \\
\text { and Applications }\end{array}$ \\
\hline Chu and Sung & 2015 & $\begin{array}{l}\text { Using a consumer socialization framework to understand electronic } \\
\text { word-of-mouth (eWOM) group membership among brand followers } \\
\text { on Twitter }\end{array}$ & $\begin{array}{l}\text { Electronic Commerce Research } \\
\text { and Applications }\end{array}$ \\
\hline Clemons and Gao & 2007 & $\begin{array}{l}\text { Consumer informedness and diverse consumer purchasing behaviors: } \\
\text { Traditional mass-market, trading down, and trading out into the long } \\
\text { tail }\end{array}$ & $\begin{array}{l}\text { Electronic Commerce Research } \\
\text { and Applications }\end{array}$ \\
\hline Curty and Zhang & 2013 & $\begin{array}{l}\text { Website features that gave rise to social commerce: a historical } \\
\text { analysis }\end{array}$ & $\begin{array}{l}\text { Electronic Commerce Research } \\
\text { and Applications }\end{array}$ \\
\hline Fang, Zhang, Bao, and Zhu & 2013 & $\begin{array}{l}\text { Towards effective online review systems in the Chinese context: A } \\
\text { cross-cultural empirical study }\end{array}$ & $\begin{array}{l}\text { Electronic Commerce Research } \\
\text { and Applications }\end{array}$ \\
\hline Hsu and Lin & 2014 & $\begin{array}{l}\text { What drives purchase intention for paid mobile apps? - An expectation } \\
\text { confirmation model with perceived value }\end{array}$ & $\begin{array}{l}\text { Electronic Commerce Research } \\
\text { and Applications }\end{array}$ \\
\hline Hsueh and Chen & 2010 & $\begin{array}{l}\text { Sharing secure m-coupons for peer-generated targeting via eWOM } \\
\text { communications }\end{array}$ & $\begin{array}{l}\text { Electronic Commerce Research } \\
\text { and Applications }\end{array}$ \\
\hline Huang, Lin, and Lin & 2008 & $\begin{array}{l}\text { Factors affecting pass-along email intentions (PAEIs): Integrating the } \\
\text { social capital and social cognition theories }\end{array}$ & $\begin{array}{l}\text { Electronic Commerce Research } \\
\text { and Applications }\end{array}$ \\
\hline Kim & 2019 & $\begin{array}{l}\text { Does national culture explain consumers' reliance on online reviews? } \\
\text { Cross-cultural variations in the effect of online review ratings on } \\
\text { consumer choice }\end{array}$ & $\begin{array}{l}\text { Electronic Commerce Research } \\
\text { and Applications }\end{array}$ \\
\hline Koh, Hu, and Clemons & 2010 & $\begin{array}{l}\text { Do online reviews reflect a product's true perceived quality? An } \\
\text { investigation of online movie reviews across cultures }\end{array}$ & $\begin{array}{l}\text { Electronic Commerce Research } \\
\text { and Applications }\end{array}$ \\
\hline $\begin{array}{l}\text { Korfiatis, García-Bariocanal, and } \\
\text { Sánchez-Alonso }\end{array}$ & 2011 & $\begin{array}{l}\text { Evaluating content quality and helpfulness of online product reviews: } \\
\text { The interplay of review helpfulness vs. review content }\end{array}$ & $\begin{array}{l}\text { Electronic Commerce Research } \\
\text { and Applications }\end{array}$ \\
\hline Lee, Park, and Han & 2008 & $\begin{array}{l}\text { The effect of negative online consumer reviews on product attitude: } \\
\text { An information processing view }\end{array}$ & $\begin{array}{l}\text { Electronic Commerce Research } \\
\text { and Applications }\end{array}$ \\
\hline $\mathrm{Li}$, Lin, and Lai & 2010 & Identifying influential reviewers for word-of-mouth marketing & $\begin{array}{l}\text { Electronic Commerce Research } \\
\text { and Applications }\end{array}$ \\
\hline Liu, He, Wang, Song, and Du & 2012 & $\begin{array}{l}\text { Combining user preferences and user opinions for accurate } \\
\text { recommendation }\end{array}$ & $\begin{array}{l}\text { Electronic Commerce Research } \\
\text { and Applications }\end{array}$ \\
\hline Ma and Wei & 2012 & $\begin{array}{l}\text { Measuring the coverage and redundancy of information search services } \\
\text { on e-commerce platforms }\end{array}$ & $\begin{array}{l}\text { Electronic Commerce Research } \\
\text { and Applications }\end{array}$ \\
\hline Mochalova and Nanopoulos & 2014 & A targeted approach to viral marketing & $\begin{array}{l}\text { Electronic Commerce Research } \\
\text { and Applications }\end{array}$ \\
\hline Moody, Galletta, and Lowry & 2014 & $\begin{array}{l}\text { When trust and distrust collide online: The engenderment and role of } \\
\text { consumer ambivalence in online consumer behavior }\end{array}$ & $\begin{array}{l}\text { Electronic Commerce Research } \\
\text { and Applications }\end{array}$ \\
\hline Park and Kim & 2008 & $\begin{array}{l}\text { The effects of consumer knowledge on message processing of } \\
\text { electronic word-of-mouth via online consumer reviews }\end{array}$ & $\begin{array}{l}\text { Electronic Commerce Research } \\
\text { and Applications }\end{array}$ \\
\hline Park and Lee & 2008 & $\begin{array}{l}\text { eWOM overload and its effect on consumer behavioral intention } \\
\text { depending on consumer involvement }\end{array}$ & $\begin{array}{l}\text { Electronic Commerce Research } \\
\text { and Applications }\end{array}$ \\
\hline Park, Gu, and Lee & 2011 & $\begin{array}{l}\text { The relationship between retailer-hosted and third-party hosted WOM } \\
\text { sources and their influence on retailer sales }\end{array}$ & $\begin{array}{l}\text { Electronic Commerce Research } \\
\text { and Applications }\end{array}$ \\
\hline Peddibhotla & 2012 & Why different motives matter in sustaining online contributions & $\begin{array}{l}\text { Electronic Commerce Research } \\
\text { and Applications }\end{array}$ \\
\hline Pöyry, Parvinen, and Malmivaara & 2013 & $\begin{array}{l}\text { Can we get from liking to buying? Behavioral differences in hedonic } \\
\text { and utilitarian Facebook usage }\end{array}$ & $\begin{array}{l}\text { Electronic Commerce Research } \\
\text { and Applications }\end{array}$ \\
\hline Racherla and Friske & 2012 & $\begin{array}{l}\text { Perceived ‘usefulness’ of online consumer reviews: An exploratory } \\
\text { investigation across three services categories }\end{array}$ & $\begin{array}{l}\text { Electronic Commerce Research } \\
\text { and Applications }\end{array}$ \\
\hline Sanchez-Franco and Rondan-Cataluña & 2009 & $\begin{array}{l}\text { Virtual travel communities and customer loyalty: Customer purchase } \\
\text { involvement and web site design }\end{array}$ & $\begin{array}{l}\text { Electronic Commerce Research } \\
\text { and Applications }\end{array}$ \\
\hline Utz, Kerkhof, and Van den Bos & 2011 & $\begin{array}{l}\text { Consumers rule: How consumer reviews influence perceived } \\
\text { trustworthiness of online stores }\end{array}$ & $\begin{array}{l}\text { Electronic Commerce Research } \\
\text { and Applications }\end{array}$ \\
\hline $\mathrm{Wu}, \mathrm{Li}$, and Kuo & 2010 & $\begin{array}{l}\text { Reputation evaluation for choosing a trustworthy counterparty in C2C } \\
\text { e-commerce }\end{array}$ & $\begin{array}{l}\text { Electronic Commerce Research } \\
\text { and Applications }\end{array}$ \\
\hline $\mathrm{Xu}, \mathrm{Guo}, \mathrm{Li}, \mathrm{Lau}$, and Liao & 2012 & $\begin{array}{l}\text { Discovering target groups in social networking sites: An effective } \\
\text { method for maximizing joint influential power }\end{array}$ & $\begin{array}{l}\text { Electronic Commerce Research } \\
\text { and Applications }\end{array}$ \\
\hline Yan, Wang, and Liu & 2014 & Research on the interactive effects of online scores & $\begin{array}{l}\text { Electronic Commerce Research } \\
\text { and Applications }\end{array}$ \\
\hline Zhang, Bian, and Zhu & 2012 & Trust fraud: A crucial challenge for China's e-commerce market & $\begin{array}{l}\text { Electronic Commerce Research } \\
\text { and Applications }\end{array}$ \\
\hline Zhou and Duan & 2011 & $\begin{array}{l}\text { Online user reviews, product variety, and the long tail: An empirical } \\
\text { investigation on online software downloads }\end{array}$ & $\begin{array}{l}\text { Electronic Commerce Research } \\
\text { and Applications }\end{array}$ \\
\hline Albert, Aggarwal, and Hill & 2014 & $\begin{array}{l}\text { Influencing customer's purchase intentions through firm participation } \\
\text { in online consumer communities }\end{array}$ & Electronic Markets \\
\hline Davis and Khazanchi & 2008 & $\begin{array}{l}\text { An Empirical Study of Online Word of Mouth as a Predictor for Multi- } \\
\text { product Category e-Commerce Sales }\end{array}$ & Electronic Markets \\
\hline Helm & 2000 & $\begin{array}{l}\text { Viral Marketing - Establishing Customer Relationships by Word-of- } \\
\text { mouse }\end{array}$ & Electronic Markets \\
\hline JONES AND RAFAELI & 2000 & $\begin{array}{l}\text { Time to Split, Virtually: ‘Discourse Architecture’ and ‘Community } \\
\text { Building' Create Vibrant Virtual Publics }\end{array}$ & Electronic Markets \\
\hline KOMIAK, KOMIAK, AND IMHOF & 2008 & $\begin{array}{l}\text { Conducting International Business at eBay: The Determinants of } \\
\text { Success of e-Stores }\end{array}$ & Electronic Markets \\
\hline MACINNES & 2005 & Causes of Disputes in Online Auctions & Electronic Markets \\
\hline Manthiou, Tang, and Bosselman & 2014 & $\begin{array}{l}\text { Reason and reaction: the dual route of the decision-making process on } \\
\text { Facebook fan pages }\end{array}$ & Electronic Markets \\
\hline Peddibhotla & 2013 & How individuals choose topics to contribute at an online context & Electronic Markets \\
\hline Zhang, Jansen, and Chowdhury & 2011 & Business engagement on Twitter: a path analysis & Electronic Markets \\
\hline
\end{tabular}




\begin{tabular}{|c|c|c|c|}
\hline Huang and Yang & 2011 & $\begin{array}{l}\text { The effects of electronic word-of-mouth messages, psychological } \\
\text { endowment, and anticipated regret on online bidding behavior }\end{array}$ & $\begin{array}{l}\text { Expert Systems with } \\
\text { Applications }\end{array}$ \\
\hline Ghose and Ipeirotis & 2011 & $\begin{array}{l}\text { Estimating the helpfulness and economic impact of product reviews: } \\
\text { Mining text and reviewer characteristics }\end{array}$ & $\begin{array}{l}\text { IEEE Transactions on } \\
\text { Knowledge and Data } \\
\text { Engineering }\end{array}$ \\
\hline Stieglitz, Meske, Ross, and Mirbabaie & 2018 & $\begin{array}{l}\text { Going Back in Time to Predict the Future - The Complex Role of the } \\
\text { Data } \\
\text { Collection Period in Social Media Analytics }\end{array}$ & Information Systems Frontiers \\
\hline Aggarwal, Gopal, Gupta, and Singh & 2012 & $\begin{array}{l}\text { Putting Money Where the Mouths Are: The Relation Between Venture } \\
\text { Financing and Electronic Word-of-Mouth }\end{array}$ & Information Systems Research \\
\hline Chen, De, and Hu & 2013 & $\begin{array}{l}\text { IT-Enabled Broadcasting in Social Media: An Empirical Study of } \\
\text { Artists’ Activities and Music Sales }\end{array}$ & Information Systems Research \\
\hline Dewan and Ramaprasad & 2012 & Music Blogging, Online Sampling, and the Long Tail & Information Systems Research \\
\hline Du, Das, Gopal, and Ramesh & 2014 & $\begin{array}{l}\text { Optimal Management of Digital Content on Tiered Infrastructure } \\
\text { Platforms }\end{array}$ & Information Systems Research \\
\hline Forman, Ghose, and Wiesenfeld & 2008 & $\begin{array}{l}\text { Examining the relationship between reviews and sales: The role of } \\
\text { reviewer identity disclosure in electronic markets }\end{array}$ & Information Systems Research \\
\hline Goes, Lin, and Au Yeung & 2014 & $\begin{array}{l}\text { "Popularity Effect" in User-Generated Content: Evidence from Online } \\
\text { Product Reviews }\end{array}$ & Information Systems Research \\
\hline Gu, Konana, Raghunathan, and Chen & 2014 & $\begin{array}{l}\text { The Allure of Homophily in Social Media: Evidence from Investor } \\
\text { Responses on Virtual Communities }\end{array}$ & Information Systems Research \\
\hline Gu, Park, and Konana & 2012 & $\begin{array}{l}\text { The Impact of External Word-of-Mouth Sources on Retailer Sales of } \\
\text { High-Involvement Products }\end{array}$ & Information Systems Research \\
\hline He, Rui, and Whinston & 2018 & Social Media Strategies in Product-Harm Crises & Information Systems Research \\
\hline $\mathrm{Ho}, \mathrm{Wu}$, and Tan & 2017 & $\begin{array}{l}\text { Disconfirmation Effect on Online Rating Behavior: A Structural } \\
\text { Model }\end{array}$ & Information Systems Research \\
\hline Jiang and Guo & 2015 & Design of Consumer Review Systems and Product Pricing & Information Systems Research \\
\hline Johnson, Safadi, and Faraj & 2015 & The Emergence of Online Community Leadership & Information Systems Research \\
\hline Lappas, Sabnis, and Valkanas & 2016 & $\begin{array}{l}\text { The Impact of Fake Reviews on Online Visibility: A Vulnerability } \\
\text { Assessment of the Hotel Industry }\end{array}$ & Information Systems Research \\
\hline Levina and Arriaga & 2014 & $\begin{array}{l}\text { Distinction and Status Production on User-Generated Content } \\
\text { Platforms: Using Bourdieu’s Theory of Cultural Production to } \\
\text { Understand Social Dynamics in Online Fields }\end{array}$ & Information Systems Research \\
\hline $\mathrm{Li}$ and Hitt & 2008 & Self-Selection and Information Role of Online Product Reviews & Information Systems Research \\
\hline Liu, Feng, and Liao & 2017 & $\begin{array}{l}\text { When Online Reviews Meet Sales Volume Information: Is More or } \\
\text { Accurate Information Always Better? }\end{array}$ & Information Systems Research \\
\hline Lu, Ba, Huang, and Feng & 2013 & $\begin{array}{l}\text { Promotional Marketing or Word-of-Mouth? Evidence from Online } \\
\text { Restaurant Reviews }\end{array}$ & Information Systems Research \\
\hline Pavlou and Dimoka & 2006 & $\begin{array}{l}\text { The nature and role of feedback text comments in online marketplaces: } \\
\text { Implications for trust building, price premiums, and seller } \\
\text { differentiation }\end{array}$ & Information Systems Research \\
\hline Phang, Kankanhalli, and Tan & 2015 & $\begin{array}{l}\text { What Motivates Contributors vs. Lurkers? An Investigation of Online } \\
\text { Feedback Forums }\end{array}$ & Information Systems Research \\
\hline Sabnis and Grewal & 2015 & $\begin{array}{l}\text { Cable News Wars on the Internet: Competition and User-Generated } \\
\text { Content }\end{array}$ & Information Systems Research \\
\hline Yan and Tan & 2014 & $\begin{array}{l}\text { Feeling Blue? Go Online: An Empirical Study of Social Support } \\
\text { Among Patients }\end{array}$ & Information Systems Research \\
\hline Yin, Mitra, and Zhang & 2017 & $\begin{array}{l}\text { When Do Consumers Value Positive } \\
\text { vs. Negative Reviews? An Empirical Investigation of Confirmation } \\
\text { Bias in Online Word of Mouth }\end{array}$ & Information Systems Research \\
\hline Zheng, Pavlou, and Gu & 2014 & $\begin{array}{l}\text { Latent Growth Modeling for Information Systems: Theoretical } \\
\text { Extensions and Practical Applications }\end{array}$ & Information Systems Research \\
\hline Aljukhadar, Senecal, and Ouellette & 2010 & $\begin{array}{l}\text { Can the Media Richness of a Privacy Disclosure Enhance Outcome? A } \\
\text { Multifaceted View of Trust in Rich Media Environments }\end{array}$ & $\begin{array}{l}\text { International Journal of } \\
\text { Electronic Commerce }\end{array}$ \\
\hline Amblee and Bui & 2008 & Can Brand Reputation Improve the Odds of Being Reviewed On-Line? & $\begin{array}{l}\text { International Journal of } \\
\text { Electronic Commerce }\end{array}$ \\
\hline Amblee and Bui & 2012 & $\begin{array}{l}\text { Harnessing the Influence of Social Proof in Online Shopping: The } \\
\text { Effect of Electronic Word of Mouth on Sales of Digital Microproducts }\end{array}$ & $\begin{array}{l}\text { International Journal of } \\
\text { Electronic Commerce }\end{array}$ \\
\hline Baek, Ahn, and Choi & 2012 & $\begin{array}{l}\text { Helpfulness of Online Consumer Reviews: Readers' Objectives and } \\
\text { Review Cues }\end{array}$ & $\begin{array}{l}\text { International Journal of } \\
\text { Electronic Commerce }\end{array}$ \\
\hline Balasubramanian and Mahajan & 2001 & The Economic Leverage of the Virtual Community & $\begin{array}{l}\text { International Journal of } \\
\text { Electronic Commerce }\end{array}$ \\
\hline Baum and Spann & 2014 & $\begin{array}{l}\text { The Interplay Between Online Consumer Reviews and Recommender } \\
\text { Systems: An Experimental Analysis }\end{array}$ & $\begin{array}{l}\text { International Journal of } \\
\text { Electronic Commerce }\end{array}$ \\
\hline Benlian and Hess & 2011 & $\begin{array}{l}\text { The Signaling Role of IT Features in Influencing Trust and } \\
\text { Participation in Online Communities }\end{array}$ & $\begin{array}{l}\text { International Journal of } \\
\text { Electronic Commerce }\end{array}$ \\
\hline Casalo, Flavian, and Guinaliu & 2011 & $\begin{array}{l}\text { Antecedents and Consequences of Consumer Participation in On-Line } \\
\text { Communities: The Case of the Travel Sector }\end{array}$ & $\begin{array}{l}\text { International Journal of } \\
\text { Electronic Commerce }\end{array}$ \\
\hline Chang, Hsieh, and Lin & 2013 & $\begin{array}{l}\text { Personality Traits That Lead Members of Online Brand Communities } \\
\text { to Participate in Information Sending and Receiving }\end{array}$ & $\begin{array}{l}\text { International Journal of } \\
\text { Electronic Commerce }\end{array}$ \\
\hline Cheung, Luo, Sia, and Chen & 2009 & $\begin{array}{l}\text { Credibility of Electronic Word-of-Mouth: Informational and } \\
\text { Normative Determinants of On-line Consumer Recommendations }\end{array}$ & $\begin{array}{l}\text { International Journal of } \\
\text { Electronic Commerce }\end{array}$ \\
\hline Chu, Roh, and Park & 2015 & $\begin{array}{l}\text { The Effect of the Dispersion of Review Ratings on Evaluations of } \\
\text { Hedonic Versus Utilitarian Products }\end{array}$ & $\begin{array}{l}\text { International Journal of } \\
\text { Electronic Commerce }\end{array}$ \\
\hline Cui, Lui, and Guo & 2012 & The Effect of Online Consumer Reviews on New Product Sales & $\begin{array}{l}\text { International Journal of } \\
\text { Electronic Commerce }\end{array}$ \\
\hline Delort, Arunasalam, and Paris & 2011 & Automatic Moderation of Online Discussion Sites & $\begin{array}{l}\text { International Journal of } \\
\text { Electronic Commerce }\end{array}$ \\
\hline Fang & 2014 & $\begin{array}{l}\text { Beyond the Credibility of Electronic Word of Mouth: Exploring } \\
\text { eWOM Adoption on Social Networking Sites from Affective and } \\
\text { Curiosity Perspectives }\end{array}$ & $\begin{array}{l}\text { International Journal of } \\
\text { Electronic Commerce }\end{array}$ \\
\hline
\end{tabular}




\begin{tabular}{|c|c|c|c|}
\hline Garnefeld, Iseke, and Krebs & 2012 & Explicit Incentives in Online Communities: Boon or Bane? & $\begin{array}{l}\text { International Journal of } \\
\text { Electronic Commerce }\end{array}$ \\
\hline Greiner and Wang & 2011 & $\begin{array}{l}\text { Building Consumer-to-Consumer Trust in E-Finance Marketplaces: An } \\
\text { Empirical Analysis }\end{array}$ & $\begin{array}{l}\text { International Journal of } \\
\text { Electronic Commerce }\end{array}$ \\
\hline Hennig-Thurau and Walsh & 2003 & $\begin{array}{l}\text { Electronic Word-of-Mouth: Motives for and Consequences of Reading } \\
\text { Customer Articulations on the Internet }\end{array}$ & $\begin{array}{l}\text { International Journal of } \\
\text { Electronic Commerce }\end{array}$ \\
\hline Hill and Ready-Campbell & 2011 & Expert Stock Picker: The Wisdom of (Experts in) Crowds & $\begin{array}{l}\text { International Journal of } \\
\text { Electronic Commerce }\end{array}$ \\
\hline Huang and Korfiatis & 2015 & $\begin{array}{l}\text { Trying Before Buying: The Moderating Role of Online Reviews in } \\
\text { Trial Attitude Formation Toward Mobile Applications }\end{array}$ & $\begin{array}{l}\text { International Journal of } \\
\text { Electronic Commerce }\end{array}$ \\
\hline Kwon and Sung & 2012 & $\begin{array}{l}\text { Shifting Selves and Product Reviews: How the Effects of Product } \\
\text { Reviews Vary Depending on the Self-Views and Self-Regulatory } \\
\text { Goals of Consumers }\end{array}$ & $\begin{array}{l}\text { International Journal of } \\
\text { Electronic Commerce }\end{array}$ \\
\hline Li, Berens, and De Maertelaere & 2014 & $\begin{array}{l}\text { Corporate Twitter Channels: The Impact of Engagement and } \\
\text { Informedness on Corporate Reputation }\end{array}$ & $\begin{array}{l}\text { International Journal of } \\
\text { Electronic Commerce }\end{array}$ \\
\hline Li, Huang, Tan, and Wei & 2013 & $\begin{array}{l}\text { Helpfulness of Online Product Reviews as Seen by Consumers: Source } \\
\text { and Content Features }\end{array}$ & $\begin{array}{l}\text { International Journal of } \\
\text { Electronic Commerce }\end{array}$ \\
\hline $\mathrm{Li}$, Lin, and Chiu & 2014 & Enhancing Targeted Advertising with Social Context Endorsement & $\begin{array}{l}\text { International Journal of } \\
\text { Electronic Commerce }\end{array}$ \\
\hline Liang, Ho, Li, and Turban & 2012 & $\begin{array}{l}\text { What Drives Social Commerce: The Role of Social Support and } \\
\text { Relationship Quality }\end{array}$ & $\begin{array}{l}\text { International Journal of } \\
\text { Electronic Commerce }\end{array}$ \\
\hline Liu, Mehandjiev, and Xu & 2013 & $\begin{array}{l}\text { Context Similarity Metric for Multidimensional Service } \\
\text { Recommendation }\end{array}$ & $\begin{array}{l}\text { International Journal of } \\
\text { Electronic Commerce }\end{array}$ \\
\hline Luarn, Yang, and Chiu & 2015 & Why People Check in to Social Network Sites & $\begin{array}{l}\text { International Journal of } \\
\text { Electronic Commerce }\end{array}$ \\
\hline Muthitachareon, Barut, and Saeed & 2014 & $\begin{array}{l}\text { The Role of Uncertainty Stemming from Product Monetary Value in } \\
\text { Online Auctions: The Case of Search Goods }\end{array}$ & $\begin{array}{l}\text { International Journal of } \\
\text { Electronic Commerce }\end{array}$ \\
\hline Olbrich and Holsing & 2012 & $\begin{array}{l}\text { Modeling Consumer Purchasing Behavior in Social Shopping } \\
\text { Communities with Clickstream Data }\end{array}$ & $\begin{array}{l}\text { International Journal of } \\
\text { Electronic Commerce }\end{array}$ \\
\hline Pagani and Mirabello & 2012 & $\begin{array}{l}\text { The Influence of Personal and Social-Interactive Engagement in Social } \\
\text { TV Web Sites }\end{array}$ & $\begin{array}{l}\text { International Journal of } \\
\text { Electronic Commerce }\end{array}$ \\
\hline Park, Lee, and Han & 2007 & $\begin{array}{l}\text { The Effect of Online Consumer Reviews on Consumer Purchasing } \\
\text { Intention: The Moderating Role of Involvement }\end{array}$ & $\begin{array}{l}\text { International Journal of } \\
\text { Electronic Commerce }\end{array}$ \\
\hline Pentina, Gammoh, Zhang, and Mallin & 2013 & $\begin{array}{l}\text { Drivers and Outcomes of Brand Relationship Quality in the Context of } \\
\text { Online Social Networks }\end{array}$ & $\begin{array}{l}\text { International Journal of } \\
\text { Electronic Commerce }\end{array}$ \\
\hline Pousttchi and Hufenbach & 2014 & $\begin{array}{l}\text { Engineering the Value Network of the Customer Interface and } \\
\text { Marketing in the Data-Rich Retail Environment }\end{array}$ & $\begin{array}{l}\text { International Journal of } \\
\text { Electronic Commerce }\end{array}$ \\
\hline Purnawirawan, Dens, and De Pelsmacker & 2013 & Balance and Sequence in Online Reviews: The Wrap Effect & $\begin{array}{l}\text { International Journal of } \\
\text { Electronic Commerce }\end{array}$ \\
\hline Riedl, Blohm, Leimeister, and Krcmar & 2013 & $\begin{array}{l}\text { The Effect of Rating Scales on Decision Quality and User Attitudes in } \\
\text { Online Innovation Communities }\end{array}$ & $\begin{array}{l}\text { International Journal of } \\
\text { Electronic Commerce }\end{array}$ \\
\hline Shen, Huang, Chu, and Liao & 2010 & Virtual Community Loyalty: An Interpersonal-Interaction Perspective & $\begin{array}{l}\text { International Journal of } \\
\text { Electronic Commerce }\end{array}$ \\
\hline Shih, Lai, and Cheng & 2013 & $\begin{array}{l}\text { Informational and Relational Influences on Electronic Word of Mouth: } \\
\text { An Empirical Study of an Online Consumer Discussion Forum }\end{array}$ & $\begin{array}{l}\text { International Journal of } \\
\text { Electronic Commerce }\end{array}$ \\
\hline Xia & 2013 & $\begin{array}{l}\text { Effects of Companies’ Responses to Consumer Criticism in Social } \\
\text { Media }\end{array}$ & $\begin{array}{l}\text { International Journal of } \\
\text { Electronic Commerce }\end{array}$ \\
\hline Yang, Tang, Dai, Yang, and Jiang & 2014 & $\begin{array}{l}\text { Identifying Implicit and Explicit Relationships Through User } \\
\text { Activities in Social Media }\end{array}$ & $\begin{array}{l}\text { International Journal of } \\
\text { Electronic Commerce }\end{array}$ \\
\hline Yen, Hsu, and Huang & 2011 & $\begin{array}{l}\text { Good Soldiers on the Web: Understanding the Drivers of Participation } \\
\text { in Online Communities of Consumption }\end{array}$ & $\begin{array}{l}\text { International Journal of } \\
\text { Electronic Commerce }\end{array}$ \\
\hline Davis and Agrawal & 2018 & $\begin{array}{l}\text { Understanding the role of interpersonal identification in online review } \\
\text { evaluation: An information processing perspective }\end{array}$ & $\begin{array}{l}\text { International Journal of } \\
\text { Information Management }\end{array}$ \\
\hline He, Zha, and Li & 2013 & $\begin{array}{l}\text { Social media competitive analysis and text mining: A case study in the } \\
\text { pizza industry }\end{array}$ & $\begin{array}{l}\text { International Journal of } \\
\text { Information Management }\end{array}$ \\
\hline Chang, Hsieh, and Tseng & 2013 & $\begin{array}{l}\text { Online brand community response to negative brand events: the role of } \\
\text { group eWOM }\end{array}$ & Internet Research \\
\hline Cheung, Lee, and Rabjohn & 2008 & $\begin{array}{l}\text { The impact of electronic word-of-mouth: The adoption of online } \\
\text { opinions in online customer communities }\end{array}$ & Internet Research \\
\hline Chiou, Hsiao, and Su & 2014 & $\begin{array}{l}\text { Whose online reviews have the most influences on consumers in } \\
\text { cultural offerings? Professional vs consumer commentators }\end{array}$ & Internet Research \\
\hline Chung & 2015 & $\begin{array}{l}\text { Solving strategy for unintended criticism in online space: Consumer } \\
\text { response to firm crisis in online discussion forum }\end{array}$ & Internet Research \\
\hline Hsiao, Lu, and Lan & 2013 & $\begin{array}{l}\text { The influence of the components of storytelling blogs on readers' travel } \\
\text { intentions }\end{array}$ & Internet Research \\
\hline Hsu, Lin, and Chiang & 2013 & $\begin{array}{l}\text { The effects of blogger recommendations on customers' online } \\
\text { shopping intentions }\end{array}$ & Internet Research \\
\hline Jalilvand and Samiei & 2012 & $\begin{array}{l}\text { The impact of electronic word of mouth on a tourism destination } \\
\text { choice Testing the theory of planned behavior (TPB) }\end{array}$ & Internet Research \\
\hline Jeong and Koo & 2015 & $\begin{array}{l}\text { Combined effects of valence and attributes of e-WOM on consumer } \\
\text { judgment for message and product: The moderating effect of brand } \\
\text { community type }\end{array}$ & Internet Research \\
\hline Kaiser and Bodendorf & 2012 & Mining consumer dialog in online forums & Internet Research \\
\hline Kalampokis, Tambouris, and Tarabanis & 2013 & Understanding the predictive power of social media & Internet Research \\
\hline Keng and Ting & 2009 & $\begin{array}{l}\text { The acceptance of blogs: using a customer experiential value } \\
\text { perspective }\end{array}$ & Internet Research \\
\hline Keng, Ting, and Chen & 2011 & $\begin{array}{l}\text { Effects of virtual-experience combinations on consumer-related "sense } \\
\text { of virtual community" }\end{array}$ & Internet Research \\
\hline Ko, Yin, and Kuo & 2008 & Exploring individual communication power in the blogosphere & Internet Research \\
\hline $\mathrm{Ku}$ & 2011 & $\begin{array}{l}\text { Recommendations from a virtual community as a catalytic agent of } \\
\text { travel decisions }\end{array}$ & Internet Research \\
\hline
\end{tabular}




\begin{tabular}{|c|c|c|c|}
\hline $\mathrm{Ku}$ & 2012 & $\begin{array}{l}\text { Beyond price: how does trust encourage online group's buying } \\
\text { intention? }\end{array}$ & Internet Research \\
\hline Lee, Cheung, Lim, and Sia & 2006 & $\begin{array}{l}\text { Understanding customer knowledge sharing in web-based discussion } \\
\text { boards - An exploratory study }\end{array}$ & Internet Research \\
\hline Lee, Kim, and Peng & 2013 & $\begin{array}{l}\text { Consumer reviews: reviewer avatar facial expression and review } \\
\text { valence }\end{array}$ & Internet Research \\
\hline Lee, Park, and Han & 2011 & $\begin{array}{l}\text { The different effects of online consumer reviews on consumers' } \\
\text { purchase intentions depending on trust in online shopping malls: An } \\
\text { advertising perspective }\end{array}$ & Internet Research \\
\hline Liu, Chen, and Chiu & 2013 & Recommending quality book reviews from heterogeneous websites & Internet Research \\
\hline McCarthy, Rowley, Ashworth, and Pioch & 2014 & $\begin{array}{l}\text { Managing brand presence through social media: the case of UK } \\
\text { football clubs }\end{array}$ & Internet Research \\
\hline Shang, Chen, and Liao & 2006 & $\begin{array}{l}\text { The value of participation in virtual consumer communities on brand } \\
\text { loyalty }\end{array}$ & Internet Research \\
\hline Shen, Chiou, and Kuo & 2011 & $\begin{array}{l}\text { Remedies for information asymmetry in online transaction: An } \\
\text { investigation into the impact of web page signals on auction outcome }\end{array}$ & Internet Research \\
\hline Steffes and Burgee & 2009 & Social ties and online word of mouth & Internet Research \\
\hline Tamimi and Sebastianelli & 2015 & $\begin{array}{l}\text { The relative importance of e-tailer website attributes on the likelihood } \\
\text { of online purchase }\end{array}$ & Internet Research \\
\hline Sun, Youn, Wu, and Kuntaraporn & 2006 & $\begin{array}{l}\text { Online word-of-mouth (or mouse): An exploration of its antecedents } \\
\text { and consequences }\end{array}$ & $\begin{array}{l}\text { Journal of Computer-Mediated } \\
\text { Communications }\end{array}$ \\
\hline Abbasi, Chen, and Nunamaker & 2008 & $\begin{array}{l}\text { Stylometric Identification in Electronic Markets: Scalability and } \\
\text { Robustness }\end{array}$ & $\begin{array}{l}\text { Journal of Management } \\
\text { Information Systems }\end{array}$ \\
\hline Awad and Ragowsky & 2008 & $\begin{array}{l}\text { Establishing Trust in Electronic Commerce Through Online Word of } \\
\text { Mouth:sE:An Examination Across Genders }\end{array}$ & $\begin{array}{l}\text { Journal of Management } \\
\text { Information Systems }\end{array}$ \\
\hline Benlian, Titah, and Hess & 2012 & $\begin{array}{l}\text { Differential Effects of Provider Recommendations and Consumer } \\
\text { Reviews in E-Commerce Transactions: An Experimental Study }\end{array}$ & $\begin{array}{l}\text { Journal of Management } \\
\text { Information Systems }\end{array}$ \\
\hline Chen, $\mathrm{Xu}$, and Whinston & 2011 & $\begin{array}{l}\text { Moderated Online Communities and Quality of User-Generated } \\
\text { Content }\end{array}$ & $\begin{array}{l}\text { Journal of Management } \\
\text { Information Systems }\end{array}$ \\
\hline Clemons, Gao, and Hitt & 2006 & $\begin{array}{l}\text { When Online Reviews Meet Hyperdifferentiation: A Study of the Craft } \\
\text { Beer Industry }\end{array}$ & $\begin{array}{l}\text { Journal of Management } \\
\text { Information Systems }\end{array}$ \\
\hline Dellarocas, Gao, and Narayan & 2010 & $\begin{array}{l}\text { Are Consumers More Likely to Contribute Online Reviews for Hit or } \\
\text { Niche Products? }\end{array}$ & $\begin{array}{l}\text { Journal of Management } \\
\text { Information Systems }\end{array}$ \\
\hline Geng, Whinston, and Zhang & 2005 & Health of Electronic Communities: An Evolutionary Game Approach & $\begin{array}{l}\text { Journal of Management } \\
\text { Information Systems }\end{array}$ \\
\hline Huang, Tan, Ke, and Wei & 2014 & $\begin{array}{l}\text { Comprehension and Assessment of Product Reviews: A Review- } \\
\text { Product Congruity Proposition }\end{array}$ & $\begin{array}{l}\text { Journal of Management } \\
\text { Information Systems }\end{array}$ \\
\hline Jensen, Averbeck, Zhang, and Wright & 2013 & $\begin{array}{l}\text { Credibility of Anonymous Online Product Reviews: A Language } \\
\text { Expectancy Perspective }\end{array}$ & $\begin{array}{l}\text { Journal of Management } \\
\text { Information Systems }\end{array}$ \\
\hline Kuan, Zhong, and Chau & 2014 & $\begin{array}{l}\text { Informational and Normative Social Influence in Group-Buying: } \\
\text { Evidence from Self-Reported and EEG Data }\end{array}$ & $\begin{array}{l}\text { Journal of Management } \\
\text { Information Systems }\end{array}$ \\
\hline Kumar, Venugopal, Qiu, and Kumar & 2018 & $\begin{array}{l}\text { Detecting Review Manipulation on Online Platforms with Hierarchical } \\
\text { Supervised Learning }\end{array}$ & $\begin{array}{l}\text { Journal of Management } \\
\text { Information Systems }\end{array}$ \\
\hline Lee and Raghu & 2014 & $\begin{array}{l}\text { Determinants of Mobile Apps' Success: Evidence from the App Store } \\
\text { Market }\end{array}$ & $\begin{array}{l}\text { Journal of Management } \\
\text { Information Systems }\end{array}$ \\
\hline Lee and Tan & 2014 & $\begin{array}{l}\text { Effects of Different Types of Free Trials and Ratings in Sampling of } \\
\text { Consumer Software: An Empirical Study }\end{array}$ & $\begin{array}{l}\text { Journal of Management } \\
\text { Information Systems }\end{array}$ \\
\hline Li, Hitt, and Zhang & 2011 & $\begin{array}{l}\text { Product Reviews and Competition in Markets for Repeat Purchase } \\
\text { Products }\end{array}$ & $\begin{array}{l}\text { Journal of Management } \\
\text { Information Systems }\end{array}$ \\
\hline Liu, Au, and Choi & 2014 & $\begin{array}{l}\text { Effects of Freemium Strategy in the Mobile App Market: An Empirical } \\
\text { Study of Google Play }\end{array}$ & $\begin{array}{l}\text { Journal of Management } \\
\text { Information Systems }\end{array}$ \\
\hline Luo and Zhang & 2013 & $\begin{array}{l}\text { How Do Consumer Buzz and Traffic in Social Media Marketing } \\
\text { Predict the Value of the Firm? }\end{array}$ & $\begin{array}{l}\text { Journal of Management } \\
\text { Information Systems }\end{array}$ \\
\hline Ma, Khansa, Deng, and Kim & 2014 & $\begin{array}{l}\text { Impact of Prior Reviews on the Subsequent Review Process in } \\
\text { Reputation Systems }\end{array}$ & $\begin{array}{l}\text { Journal of Management } \\
\text { Information Systems }\end{array}$ \\
\hline $\begin{array}{l}\text { Pathak, Garfinkel, Gopal, Venkatesan, } \\
\text { and Yin }\end{array}$ & 2010 & Empirical Analysis of the Impact of Recommender Systems on Sales & $\begin{array}{l}\text { Journal of Management } \\
\text { Information Systems }\end{array}$ \\
\hline Porter, Devaraj, and Sun & 2013 & A Test of Two Models of Value Creation in Virtual Communities & $\begin{array}{l}\text { Journal of Management } \\
\text { Information Systems }\end{array}$ \\
\hline Qahri-Saremi and Montazemi & 2019 & $\begin{array}{l}\text { Factors Affecting the Adoption of an Electronic } \\
\text { Word of Mouth Message: A Meta-Analysis }\end{array}$ & $\begin{array}{l}\text { Journal of Management } \\
\text { Information Systems }\end{array}$ \\
\hline Park and Nicolau & 2015 & Asymmetric effects of online consumer reviews & Annals of Tourism Research \\
\hline Bridges and Vasquez & 2016 & $\begin{array}{l}\text { If nearly all Airbnb reviews are positive, does that make them } \\
\text { meaningless? }\end{array}$ & Current Issues in Tourism \\
\hline Gössling, Hall, and Andersson & 2018 & $\begin{array}{l}\text { The manager's dilemma: A conceptualization of online review } \\
\text { manipulation strategies }\end{array}$ & Current Issues in Tourism \\
\hline Litvin, Goldsmith, and Pan & 2018 & $\begin{array}{l}\text { A Retrospective View of Electronic Word-of-mouth in Hospitality and } \\
\text { Tourism Management }\end{array}$ & $\begin{array}{l}\text { International Journal of } \\
\text { Contemporary } \\
\text { Hospitality Management } \\
\end{array}$ \\
\hline $\begin{array}{l}\text { Afonso Dias, Perdigao Ribeiro, and } \\
\text { Correia }\end{array}$ & 2013 & Online reviews of short-term visits: exploring sense of place & $\begin{array}{l}\text { International Journal of Culture, } \\
\text { Tourism, and Hospitality } \\
\text { Research }\end{array}$ \\
\hline Cheng and Jin & 2019 & $\begin{array}{l}\text { What do Airbnb users care about? An analysis of online review } \\
\text { comments }\end{array}$ & $\begin{array}{l}\text { International Journal of } \\
\text { Hospitality Management }\end{array}$ \\
\hline Gursoy & 2018 & $\begin{array}{l}\text { A critical review of determinants of information search behavior and } \\
\text { utilization of online reviews in decision making process }\end{array}$ & $\begin{array}{l}\text { International Journal of } \\
\text { Hospitality Management }\end{array}$ \\
\hline Xie, Zhang, and Zhang & 2015 & $\begin{array}{l}\text { The business value of online consumer reviews and management } \\
\text { response to hotel performance }\end{array}$ & $\begin{array}{l}\text { International Journal of } \\
\text { Hospitality Management }\end{array}$ \\
\hline Ye, Law, and Gu & 2009 & The Impact of Online User Reviews on Hotel Room Sales & $\begin{array}{l}\text { International Journal of } \\
\text { Hospitality Management }\end{array}$ \\
\hline
\end{tabular}




\begin{tabular}{|c|c|c|c|}
\hline Burgess, Sellitto, Cox, and Buultjens & 2014 & $\begin{array}{l}\text { Strategies for Adopting Consumer-generated Media in Small-sized to } \\
\text { Medium-sized Tourism Enterprises }\end{array}$ & $\begin{array}{l}\text { International Journal of } \\
\text { Tourism Research }\end{array}$ \\
\hline $\mathrm{Ku}$ & 2014 & Distributed Fascinating Knowledge Over an Online Travel Community & $\begin{array}{l}\text { International Journal of } \\
\text { Tourism Research }\end{array}$ \\
\hline Leung, Law, and Lee & 2011 & The Perceived Destination Image of Hong Kong on Ctrip.com & $\begin{array}{l}\text { International Journal of } \\
\text { Tourism Research }\end{array}$ \\
\hline Leung, Wang, Wu, Bai, Stahura, and Xie & 2012 & $\begin{array}{l}\text { A Social Network Analysis of Overseas Tourist Movement Patterns in } \\
\text { Beijing: The Impact of the Olympic Games }\end{array}$ & $\begin{array}{l}\text { International Journal of } \\
\text { Tourism Research }\end{array}$ \\
\hline Nusair, Bilgihan, and Okumus & 2012 & $\begin{array}{l}\text { The Role of Online Social Network Travel Websites in Creating Social } \\
\text { Interaction for Gen Y Travelers }\end{array}$ & $\begin{array}{l}\text { International Journal of } \\
\text { Tourism Research }\end{array}$ \\
\hline Sigala & 2012 & $\begin{array}{l}\text { Exploiting Web } 2.0 \text { for New Service Development: Findings and } \\
\text { Implications from the Greek Tourism Industry }\end{array}$ & $\begin{array}{l}\text { International Journal of } \\
\text { Tourism Research }\end{array}$ \\
\hline Tsaur, Wu, Yen, and Wu & 2013 & $\begin{array}{l}\text { Promoting Relationship Marketing of Tour Leaders' Blog: The Role of } \\
\text { Charisma }\end{array}$ & $\begin{array}{l}\text { International Journal of } \\
\text { Tourism Research }\end{array}$ \\
\hline Berezan, Raab, Tanford, and Kim & 2015 & $\begin{array}{l}\text { Evaluating Loyalty Constructs Among Hotel Reward Program } \\
\text { Members Using eWOM }\end{array}$ & $\begin{array}{l}\text { Journal of Hospitality and } \\
\text { Tourism Research }\end{array}$ \\
\hline Kim and Lee & 2015 & $\begin{array}{l}\text { How do consumers process online hotel reviews? The Effects of } \\
\text { eWOM consensus and sequence }\end{array}$ & $\begin{array}{l}\text { Journal of Hospitality and } \\
\text { Tourism Research }\end{array}$ \\
\hline Lee and Cranage & 2014 & $\begin{array}{l}\text { Toward Understanding Consumer Processing of Negative Online } \\
\text { Word-Of-Mouth Communication: The Roles of Opinion Consensus } \\
\text { and Organizational Response Strategies }\end{array}$ & $\begin{array}{l}\text { Journal of Hospitality and } \\
\text { Tourism Research }\end{array}$ \\
\hline Leung, Bai, and Stahura & 2015 & $\begin{array}{l}\text { The marketing effectiveness of social media in the hotel industry: a } \\
\text { comparison of Facebook and Twitter }\end{array}$ & $\begin{array}{l}\text { Journal of Hospitality and } \\
\text { Tourism Research }\end{array}$ \\
\hline Mkono & 2013 & $\begin{array}{l}\text { Using net-based ethnography (netnography) to understand the staging } \\
\text { and marketing of "authentic african" dining experiences to tourists at } \\
\text { Victoria Falls }\end{array}$ & $\begin{array}{l}\text { Journal of Hospitality and } \\
\text { Tourism Research }\end{array}$ \\
\hline Noone and McGuire & 2014 & $\begin{array}{l}\text { Effects of price and user-generated content on consumers' repurchase } \\
\text { evaluations of variably priced services }\end{array}$ & $\begin{array}{l}\text { Journal of Hospitality and } \\
\text { Tourism Research }\end{array}$ \\
\hline Ye, Li, Wang, and Law & 2014 & $\begin{array}{l}\text { The influence of hotel price on perceived service quality and value in } \\
\text { e-tourism: an empirical investigation based on online traveler reviews }\end{array}$ & $\begin{array}{l}\text { Journal of Hospitality and } \\
\text { Tourism Research }\end{array}$ \\
\hline Memarzadeh, Blum, and Adams & 2015 & $\begin{array}{l}\text { The impact of positive and negative e-comments on business travelers' } \\
\text { intention to purchase a hotel room }\end{array}$ & $\begin{array}{l}\text { Journal of Hospitality and } \\
\text { Tourism Technology }\end{array}$ \\
\hline Pantano and Di Pietro & 2013 & $\begin{array}{l}\text { From e-tourism to f-tourism: emerging issues from negative tourists' } \\
\text { online reviews }\end{array}$ & $\begin{array}{l}\text { Journal of Hospitality and } \\
\text { Tourism Technology }\end{array}$ \\
\hline Dinçer and Alrawadieh & 2017 & $\begin{array}{l}\text { Negative word of mouse in the hotel industry: A content analysis of } \\
\text { online reviews on luxury hotels in Jordan }\end{array}$ & $\begin{array}{l}\text { Journal of Hospitality } \\
\text { Marketing \& Management }\end{array}$ \\
\hline Liang, Choi, and Joppe & 2018 & $\begin{array}{l}\text { Understanding repurchase intention of Airbnb consumers: perceived } \\
\text { authenticity, electronic word-of-mouth, and price sensitivity }\end{array}$ & $\begin{array}{l}\text { Journal of Travel \& Tourism } \\
\text { Marketing }\end{array}$ \\
\hline Cheng and Loi & 2014 & $\begin{array}{l}\text { Handling Negative Online Customer Reviews: The Effects of } \\
\text { Elaboration Likelihood Model and Distributive Justice }\end{array}$ & $\begin{array}{l}\text { Journal of Travel and Tourism } \\
\text { Marketing }\end{array}$ \\
\hline Schuckert, Liu, and Law & 2015 & $\begin{array}{l}\text { Hospitality and Tourism Online Reviews: Recent Trends and Future } \\
\text { Directions }\end{array}$ & $\begin{array}{l}\text { Journal of Travel and Tourism } \\
\text { Marketing }\end{array}$ \\
\hline Schuckert, Liu, and Law & 2015 & Stars, Votes, and Badges: How Online Badges Affect Hotel Reviewers & $\begin{array}{l}\text { Journal of Travel and Tourism } \\
\text { Marketing }\end{array}$ \\
\hline Abrate and Viglia & 2017 & $\begin{array}{l}\text { Personal or Product Reputation? Optimizing Revenues in the Sharing } \\
\text { Economy }\end{array}$ & Journal of Travel Research \\
\hline Arsal, Woosnam, Baldwin, and Backman & 2010 & $\begin{array}{l}\text { Residents as Travel Destination Information Providers: An Online } \\
\text { Community Perspective }\end{array}$ & Journal of Travel Research \\
\hline Ayeh, Au, and Law & 2013 & $\begin{array}{l}\text { “Do We Believe in TripAdvisor?” Examining Credibility Perceptions } \\
\text { and Online Travelers' Attitude toward Using User-Generated Content }\end{array}$ & Journal of Travel Research \\
\hline Banyai and Glover & 2012 & Evaluating Research Methods on Travel Blogs & Journal of Travel Research \\
\hline Bronner and De Hoog & 2011 & Vacationers and eWOM: Who Posts, and Why, Where, and What? & Journal of Travel Research \\
\hline Crotts, Mason, and Davis & 2009 & $\begin{array}{l}\text { Measuring Guest Satisfaction and Competitive Position in the } \\
\text { Hospitality and Tourism Industry: An Application of Stance-Shift } \\
\text { Analysis to Travel Blog Narratives }\end{array}$ & Journal of Travel Research \\
\hline Duverger & 2013 & $\begin{array}{l}\text { Curvilinear Effects of User-Generated Content on Hotels’ Market } \\
\text { Share: A Dynamic Panel-Data Analysis }\end{array}$ & Journal of Travel Research \\
\hline Filieri and McLeay & 2013 & $\begin{array}{l}\text { E-WOM and Accommodation: An Analysis of the Factors That } \\
\text { Influence Travelers' Adoption of Information from Online Reviews }\end{array}$ & Journal of Travel Research \\
\hline Magnini, Crotts, and Zehrer & 2011 & $\begin{array}{l}\text { Understanding Customer Delight: An Application of Travel Blog } \\
\text { Analysis }\end{array}$ & Journal of Travel Research \\
\hline Pan, MacLaurin, and Crotts & 2007 & Travel Blogs and the Implications for Destination Marketing & Journal of Travel Research \\
\hline Sun, Ryan, and Pan & 2015 & $\begin{array}{l}\text { Using Chinese Travel Blogs to Examine Perceived Destination Image: } \\
\text { The Case of New Zealand }\end{array}$ & Journal of Travel Research \\
\hline Wang and Fesenmaier & 2004 & Modeling Participation in an Online Travel Community & Journal of Travel Research \\
\hline Chaves, Gomes, and Pedron & 2012 & $\begin{array}{l}\text { Analysing reviews in the Web 2.0: Small and medium hotels in } \\
\text { Portugal }\end{array}$ & Tourism Management \\
\hline Filieri, Alguezaui, and McLeay & 2015 & $\begin{array}{l}\text { Why do travelers trust TripAdvisor? Antecedents of trust towards } \\
\text { consumer-generated media and its influence on recommendation } \\
\text { adoption and word of mouth }\end{array}$ & Tourism Management \\
\hline Kim and Stepchenkova & 2015 & $\begin{array}{l}\text { Effect of tourist photographs on attitudes towards destination: Manifest } \\
\text { and latent content }\end{array}$ & Tourism Management \\
\hline Li, Law, Vu, Rong, and Zhao & 2015 & $\begin{array}{l}\text { Identifying emerging hotel preferences using Emerging Pattern Mining } \\
\text { technique }\end{array}$ & Tourism Management \\
\hline Litvin, Goldsmith, and Pan & 2008 & Electronic word-of-mouth in hospitality and tourism management & Tourism Management \\
\hline Liu and Park & 2015 & $\begin{array}{l}\text { What makes a useful online review? Implication for travel product } \\
\text { websites }\end{array}$ & Tourism Management \\
\hline $\begin{array}{l}\text { Llodra-Riera, Martinez-Ruiz, Jimenez- } \\
\text { Zarco, and Izquierdo-Yusta }\end{array}$ & 2015 & $\begin{array}{l}\text { A multidimensional analysis of the information sources construct and } \\
\text { its relevance for destination image formation }\end{array}$ & Tourism Management \\
\hline Lui, Bartosiak, Piccoli, and Sadhya & 2018 & $\begin{array}{l}\text { Online review response strategy and its effects on competitive } \\
\text { performance }\end{array}$ & Tourism Management \\
\hline
\end{tabular}




\begin{tabular}{|c|c|c|c|}
\hline Luo and Zhong & 2015 & $\begin{array}{l}\text { Using social network analysis to explain communication } \\
\text { characteristics of travel-related electronic word-of-mouth on social } \\
\text { networking sites }\end{array}$ & Tourism Management \\
\hline Mariani, Borghi, and Gretzel & 2019 & Online reviews: Differences by submission device & Tourism Management \\
\hline Munar and Jacobsen & 2014 & Motivations for sharing tourism experiences through social media & Tourism Management \\
\hline $\begin{array}{l}\text { Nieto, Hernández-Maestro, and Muñoz- } \\
\text { Gallego }\end{array}$ & 2014 & $\begin{array}{l}\text { Marketing decisions, customer reviews, and business performance: } \\
\text { The use of the Toprural website by Spanish rural lodging } \\
\text { establishments }\end{array}$ & Tourism Management \\
\hline Papathanassis and Knolle & 2011 & $\begin{array}{l}\text { Exploring the adoption and processing of online holiday reviews: A } \\
\text { grounded theory approach }\end{array}$ & Tourism Management \\
\hline Phillips, Zigan, Santos Silva, and Schegg & 2015 & $\begin{array}{l}\text { The interactive effects of online reviews on the determinants of Swiss } \\
\text { hotel performance: A neural network analysis }\end{array}$ & Tourism Management \\
\hline Rong, Vu, Law, and Li & 2012 & $\begin{array}{l}\text { A behavioral analysis of web sharers and browsers in Hong Kong } \\
\text { using targeted association rule mining }\end{array}$ & Tourism Management \\
\hline Sparks and Browning & 2011 & $\begin{array}{l}\text { The impact of online reviews on hotel booking intentions and } \\
\text { perception of trust }\end{array}$ & Tourism Management \\
\hline Sparks, Perkins, and Buckley & 2013 & $\begin{array}{l}\text { Online travel reviews as persuasive communication: The effects of } \\
\text { content type, source, and certification logos on consumer behavior }\end{array}$ & Tourism Management \\
\hline Stepchenkova and Zhan & 2013 & $\begin{array}{l}\text { Visual destination images of Peru: Comparative content analysis of } \\
\text { DMO and user-generated photography }\end{array}$ & Tourism Management \\
\hline Tseng, Wu, Morrison, Zhang, and Chen & 2015 & $\begin{array}{l}\text { Travel blogs on China as a destination image formation agent: A } \\
\text { qualitative analysis using Leximancer }\end{array}$ & Tourism Management \\
\hline Vermeulen and Seegers & 2009 & $\begin{array}{l}\text { Tried and tested: The impact of online hotel reviews on consumer } \\
\text { consideration }\end{array}$ & Tourism Management \\
\hline Yan, Zhou, and Wu & 2018 & $\begin{array}{l}\text { The influences of tourists' emotions on the selection of electronic } \\
\text { word of mouth platforms }\end{array}$ & Tourism Management \\
\hline Yang, Park, and $\mathrm{Hu}$ & 2018 & Electronic word of mouth and hotel performance: A meta-analysis & Tourism Management \\
\hline Callarisa, García, Cardiff, and Roshchina & 2012 & $\begin{array}{l}\text { Harnessing social media platforms to measure customer-based hotel } \\
\text { brand equity }\end{array}$ & $\begin{array}{l}\text { Tourism Management } \\
\text { Perspectives }\end{array}$ \\
\hline Jacobsen and Munar & 2012 & Tourist information search and destination choice in a digital age & $\begin{array}{l}\text { Tourism Management } \\
\text { Perspectives }\end{array}$ \\
\hline Mkono, Markwell, and Wilson & 2013 & $\begin{array}{l}\text { Applying Quan and Wang's structural model of the tourist experience: } \\
\text { A Zimbabwean netnography of food tourism }\end{array}$ & $\begin{array}{l}\text { Tourism Management } \\
\text { Perspectives }\end{array}$ \\
\hline Nguyen and Coudounaris & 2015 & The mechanism of online review management: A qualitative study & $\begin{array}{l}\text { Tourism Management } \\
\text { Perspectives }\end{array}$ \\
\hline Radojevic, Stanisic, and Stanic & 2015 & $\begin{array}{l}\text { Solo travellers assign higher ratings than families: Examining } \\
\text { customer satisfaction by demographic group }\end{array}$ & $\begin{array}{l}\text { Tourism Management } \\
\text { Perspectives }\end{array}$ \\
\hline Ukpabi and Karjaluoto & 2018 & $\begin{array}{l}\text { What drives travelers' adoption of user-generated content? A literature } \\
\text { review }\end{array}$ & $\begin{array}{l}\text { Tourism Management } \\
\text { Perspectives }\end{array}$ \\
\hline
\end{tabular}




\section{Web Appendix 3}

\section{Research evolution and major milestones}

In the late 1990s, before the transition of traditional (i.e., offline) WOM to the Internet became apparent, researchers highlighted the new WOM opportunities provided by online media and thus implied eWOM by noting various platforms and aggregations of consumers in cyberspacefor example, by using the term "virtual community of consumption” (Kozinets 1999, p. 253). Soon after 2000, scholars turned their attention to the motivation behind eWOM, leading to a proliferation of eWOM conceptual labels highlighting the consumer perspective (e.g., UGC, feedback). At that time, eWOM occurred primarily through online discussion platforms, which then gave way to the creation of cohesive consumer communities organized around brands or consumption activities (Kozinets 2002; McAlexander et al. 2002). Connecting with like-minded others online was a new experience that was an attraction in itself, and social benefit was the primary motivator of eWOM creation.

Halfway through the 2000s, a revolution occurred on social media platforms, and discussion forums and chat rooms lost their attraction. The new social networks (e.g., Facebook, Instagram, Twitter) afforded connections and communication differently. Whereas consumers typically formed strong social bonds in the early days of online communities, today they predominantly form publics (Arvidsson and Caliandro 2016; Hayes et al. 2016) — that is, looser gatherings of individuals temporarily linked through hashtags to give publicity to a shared interest, such as a brand, person, or cause (e.g., \#BeliebersHelpBeliebers, Langley et al. 2014). Berger (2014) qualifies this trend as driven by self-interested impression management.

Over time, eWOM also became increasingly negative, as eWOM environments matured and consumers began using eWOM to signal their expertise (Godes and Silva 2012; Moe and Schweidel 2012). Not surprisingly, a wealth of research has analyzed “sentiment” and "valence.” As rising Internet adoptions gave eWOM more reach, its buying influence substantially 
increased by 2005 (Chen et al. 2011a), causing the research focus to shift to the consequences of eWOM on the bottom line. The easier access to review data and the ability to use product rankings as a proxy for online sales made terms such as "rating” and "review” more popular in the eWOM literature.

As the field continued to expand, researchers began combining key terms to develop unique conceptual labels ${ }^{1}$ (e.g., “word-of-web recommendations within virtual consumer communities”; Dambrin and De Valck 2007, p. 451) to signal their specific topic of inquiry. In some studies, however, eWOM remained merely alluded to by mention of a specific type of platform that enables consumer-generated entries. Pühringer and Taylor (2008), for example, use “travel blogs” to signify tourists’ eWOM. In acknowledging this practice, McQuarrie et al. (2013, p. 136) define "blogging as one instance of a larger phenomenon that includes online reviews ... and extends to the consumption of [many product categories].”

The existence of various conceptual labels shows an overwhelming interest in the eWOM phenomenon. At the same time, this inconsistent nomenclature (Marchand et al. 2017) causes confusion; for example, the drop of publications on eWOM in the last few years could be due to the usage of different labels (e.g., "social media”) instead of decreasing academic interest.

Understanding related conceptual labels also informs meta-analytic work (Palmatier et al. 2006), in which the quest for empirical studies of the same phenomenon requires thoughtful consideration of construct labels. The proliferation of labels thus necessitates a discussion about what eWOM is and what it is not.

\footnotetext{
${ }^{1}$ As part of our content analysis, one coder first manually classified eWOM labels in a corpus. We then employed automated textual analysis to capture labels appearing in a publication's title, abstract, or keywords. We find that most of the 390 identified eWOM labels are used only a handful of times. This means that most eWOM labels are not catching on beyond a small number of academic articles.
} 


\section{Web Appendix 4}

\section{eWOM conceptual labels: aliases (1996-2019)}

\begin{tabular}{|c|c|}
\hline No. & eWOM Alias \\
\hline 1 & 3rd party consensus rating \\
\hline 2 & ad eWOM \\
\hline 3 & $\begin{array}{l}\text { aggregate consumer } \\
\text { preference }\end{array}$ \\
\hline 4 & aggregate polarity score \\
\hline 5 & aggregated rating \\
\hline 6 & amateur feedback \\
\hline 7 & amateur rating \\
\hline 8 & Amazon Like \\
\hline 9 & antibrand community \\
\hline 10 & average user grade \\
\hline 11 & average user review \\
\hline 12 & blog \\
\hline 13 & blog buzz \\
\hline 14 & blog conversation \\
\hline 15 & blog post \\
\hline 16 & blog reference \\
\hline 17 & blogger buzz \\
\hline 18 & blogger sentiment \\
\hline 19 & blogging \\
\hline 20 & blogosphere \\
\hline 21 & brand community \\
\hline 22 & brand evaluation \\
\hline 23 & brand eWOM \\
\hline 24 & brand public \\
\hline 25 & brand-embedded interaction \\
\hline 26 & $\begin{array}{l}\text { brand-related user-generated } \\
\text { content }\end{array}$ \\
\hline 27 & buyer-created information \\
\hline 28 & buzz \\
\hline 29 & buzz in online chatter \\
\hline 30 & buzz in social media \\
\hline 31 & buzz marketing \\
\hline 32 & C2C advocacy \\
\hline 33 & $\begin{array}{l}\mathrm{C} 2 \mathrm{C} \text { communications in } \\
\text { online brand } \\
\text { community }\end{array}$ \\
\hline 34 & CGM \\
\hline 35 & CGM content \\
\hline 36 & chatter \\
\hline 37 & commercial chatting \\
\hline 38 & community content \\
\hline 39 & community of consumption \\
\hline 40 & $\begin{array}{l}\text { computer mediated } \\
\text { communication }\end{array}$ \\
\hline 41 & $\begin{array}{l}\text { consumer activity in social } \\
\text { media }\end{array}$ \\
\hline 42 & consumer attitude \\
\hline 43 & consumer buzz \\
\hline 44 & consumer comment \\
\hline
\end{tabular}

\begin{tabular}{|c|c|}
\hline No. & eWOM Alias \\
\hline 45 & consumer commentary \\
\hline 46 & consumer communication \\
\hline 47 & consumer conversation \\
\hline 48 & consumer evaluation \\
\hline 49 & consumer eWOM \\
\hline 50 & consumer feedback \\
\hline 51 & consumer interaction \\
\hline 52 & consumer media \\
\hline 53 & consumer narrative \\
\hline 54 & $\begin{array}{l}\text { consumer online activity } \\
\text { around new products }\end{array}$ \\
\hline 55 & $\begin{array}{l}\text { consumer online product } \\
\text { rating }\end{array}$ \\
\hline 56 & consumer online talk \\
\hline 57 & $\begin{array}{l}\text { consumer online word of } \\
\text { mouth }\end{array}$ \\
\hline 58 & consumer opinion posting \\
\hline 59 & consumer post on Facebook \\
\hline 60 & consumer posting \\
\hline 61 & $\begin{array}{l}\text { consumer posts in social } \\
\text { media outlets }\end{array}$ \\
\hline 62 & consumer price posting \\
\hline 63 & consumer product judgment \\
\hline 64 & consumer product narrative \\
\hline 65 & $\begin{array}{l}\text { consumer product review in } \\
\text { the online market }\end{array}$ \\
\hline 66 & consumer rating \\
\hline 67 & consumer reaction \\
\hline 68 & consumer recommendation \\
\hline 69 & consumer response \\
\hline 70 & consumer review \\
\hline 71 & consumer sentiment \\
\hline 72 & consumer social interaction \\
\hline 73 & consumer storytelling \\
\hline 74 & consumer talk \\
\hline 75 & consumer text review \\
\hline 76 & consumer voice \\
\hline 77 & consumer word of mouth \\
\hline 78 & $\begin{array}{l}\text { consumer-created } \\
\text { communications }\end{array}$ \\
\hline 79 & consumer-created content \\
\hline 80 & consumer-created information \\
\hline 81 & consumer-driven eWOM \\
\hline 82 & $\begin{array}{l}\text { consumer-generated anti- } \\
\text { brand social networking site }\end{array}$ \\
\hline 83 & $\begin{array}{l}\text { consumer-generated brand- } \\
\text { related Pinterest page }\end{array}$ \\
\hline 84 & consumer-generated campaign \\
\hline 85 & consumer-generated content \\
\hline 86 & $\begin{array}{l}\text { consumer-generated electronic } \\
\text { word-of-mouth }\end{array}$ \\
\hline 87 & $\begin{array}{l}\text { consumer-generated } \\
\text { information }\end{array}$ \\
\hline
\end{tabular}

\begin{tabular}{|c|c|}
\hline No. & eWOM Alias \\
\hline 88 & consumer-generated media \\
\hline 89 & $\begin{array}{l}\text { consumer-generated media } \\
\text { content }\end{array}$ \\
\hline 90 & consumer-generated message \\
\hline 91 & consumer-generated narrative \\
\hline 92 & $\begin{array}{l}\text { consumer-generated online } \\
\text { review }\end{array}$ \\
\hline 93 & consumer-generated platform \\
\hline 94 & $\begin{array}{l}\text { consumer-generated product } \\
\text { page }\end{array}$ \\
\hline 95 & $\begin{array}{l}\text { consumer-generated product } \\
\text { rating }\end{array}$ \\
\hline 96 & $\begin{array}{l}\text { consumer-generated product } \\
\text { review }\end{array}$ \\
\hline 97 & consumer-generated review \\
\hline 98 & $\begin{array}{l}\text { consumer-generated word-of- } \\
\text { mouth }\end{array}$ \\
\hline 99 & $\begin{array}{l}\text { consumers' voicing of } \\
\text { discontent in blog posts }\end{array}$ \\
\hline 100 & $\begin{array}{l}\text { consumer-to-consumer } \\
\text { communication }\end{array}$ \\
\hline 101 & $\begin{array}{l}\text { consumer-to-consumer } \\
\text { interaction }\end{array}$ \\
\hline 102 & $\begin{array}{l}\text { consumer-to-consumer } \\
\text { narrative interaction }\end{array}$ \\
\hline 103 & $\begin{array}{l}\text { consumer-to-consumer online } \\
\text { communication }\end{array}$ \\
\hline 104 & $\begin{array}{l}\text { consumer-to-consumer WOM } \\
\text { conversation }\end{array}$ \\
\hline 105 & $\begin{array}{l}\text { consumer-to-consumer word } \\
\text { of mouth on the internet }\end{array}$ \\
\hline 106 & $\begin{array}{l}\text { contagious commentary about } \\
\text { products, services, brands, and } \\
\text { ideas }\end{array}$ \\
\hline 107 & $\begin{array}{l}\text { conversation Internet } \\
\text { community }\end{array}$ \\
\hline 108 & crowd-based wisdom \\
\hline 109 & customer expression \\
\hline 110 & customer feedback on the web \\
\hline 111 & customer knowledge sharing \\
\hline 112 & $\begin{array}{l}\text { customer opinions in social } \\
\text { media }\end{array}$ \\
\hline 113 & customer rating \\
\hline 114 & customer referral \\
\hline 115 & customer referral intensity \\
\hline 116 & customer review \\
\hline 117 & $\begin{array}{l}\text { customer-created complaint } \\
\text { web site }\end{array}$ \\
\hline 118 & $\begin{array}{l}\text { customer-generated brand } \\
\text { message }\end{array}$ \\
\hline 119 & customer-generated opinion \\
\hline 120 & $\begin{array}{l}\text { customer-to-customer know- } \\
\text { how exchange }\end{array}$ \\
\hline 121 & desktop eWOM \\
\hline 122 & digital community \\
\hline 123 & digital conversation \\
\hline 124 & digital storytelling \\
\hline 125 & digital word of mouth \\
\hline
\end{tabular}




\begin{tabular}{|c|c|}
\hline No. & eWOM Alias \\
\hline 126 & digitized word of mouth \\
\hline 127 & discussion forums \\
\hline 128 & discussions among consumers \\
\hline 129 & dispersion \\
\hline 130 & e-buzz \\
\hline 131 & e-comment \\
\hline 132 & $\begin{array}{l}\text { e-customer-to-customer } \\
\text { interaction in B2B brand } \\
\text { communities }\end{array}$ \\
\hline 133 & earned audience \\
\hline 134 & $\begin{array}{l}\text { earned media impressions on } \\
\text { Facebook }\end{array}$ \\
\hline 135 & $\begin{array}{l}\text { electronic consumer-to- } \\
\text { consumer communication }\end{array}$ \\
\hline 136 & electronic referral \\
\hline 137 & electronic word of mouth \\
\hline 138 & e-referral \\
\hline 139 & evaluative judgment \\
\hline 140 & eWOM \\
\hline 141 & eWOM conversation \\
\hline 142 & eWOM instrument \\
\hline 143 & eWOM of user message \\
\hline 144 & eWOM recommendation \\
\hline 145 & eWOM review \\
\hline 146 & external WOM \\
\hline 147 & Facebook fan \\
\hline 148 & Facebook fan page \\
\hline 149 & Facebook Like \\
\hline 150 & Facebook-mediated WOM \\
\hline 151 & fashion blog \\
\hline 152 & feedback \\
\hline 153 & feedback mechanism \\
\hline 154 & feedback review \\
\hline 155 & feedback score \\
\hline 156 & firm's consumer buzz \\
\hline 157 & hype on Twitter \\
\hline 158 & internal WOM \\
\hline 159 & Internet user opinion \\
\hline 160 & Internet WOM \\
\hline 161 & $\begin{array}{l}\text { Internet word-of-mouth } \\
\text { communication }\end{array}$ \\
\hline 162 & $\begin{array}{l}\text { Internet-enabled online word- } \\
\text { of-mouth communications } \\
\text { among consumers }\end{array}$ \\
\hline 163 & invite \\
\hline 164 & $\begin{array}{l}\text { member-generated } \\
\text { information }\end{array}$ \\
\hline 165 & microblog reaction \\
\hline 166 & microblogging \\
\hline 167 & microblogging word of mouth \\
\hline 168 & microblogosphere \\
\hline 169 & mobile eWOM \\
\hline 170 & mWOM \\
\hline 171 & $\begin{array}{l}\text { negative (online) brand } \\
\text { imagery }\end{array}$ \\
\hline
\end{tabular}

\begin{tabular}{|c|c|}
\hline No. & eWOM Alias \\
\hline 172 & new media \\
\hline 173 & numeric rating \\
\hline 174 & numeric review rating \\
\hline 175 & OCR \\
\hline 176 & online amateur review \\
\hline 177 & online articulation \\
\hline 178 & online attitude \\
\hline 179 & online blog posting \\
\hline 180 & online brand advocacy \\
\hline 181 & online brand evaluation \\
\hline 182 & online brand tribalism \\
\hline 183 & online buzz \\
\hline 184 & online buzz activity \\
\hline 185 & online C2C conversation \\
\hline 186 & online CGM \\
\hline 187 & online chatter \\
\hline 188 & online comment \\
\hline 189 & $\begin{array}{l}\text { online comment about a } \\
\text { product }\end{array}$ \\
\hline 190 & online communication \\
\hline 191 & $\begin{array}{l}\text { online community of } \\
\text { consumption }\end{array}$ \\
\hline 192 & online community post \\
\hline 193 & online complaining \\
\hline 194 & online consumer attitude \\
\hline 195 & online consumer content \\
\hline 196 & online consumer evaluation \\
\hline 197 & $\begin{array}{l}\text { online consumer product } \\
\text { review }\end{array}$ \\
\hline 198 & online consumer rating \\
\hline 199 & online consumer review \\
\hline 200 & online consumer voice \\
\hline 201 & $\begin{array}{l}\text { online consumer-generated } \\
\text { content }\end{array}$ \\
\hline 202 & $\begin{array}{l}\text { online consumer-generated } \\
\text { media }\end{array}$ \\
\hline 203 & $\begin{array}{l}\text { online consumer-generated } \\
\text { review }\end{array}$ \\
\hline 204 & online content \\
\hline 205 & online conversation \\
\hline 206 & online customer dialogue \\
\hline 207 & online discourse \\
\hline 208 & online discussion \\
\hline 209 & online feedback \\
\hline 210 & online feedback mechanism \\
\hline 211 & online forum \\
\hline 212 & online media \\
\hline 213 & online merchant review \\
\hline 214 & online message \\
\hline 215 & online message on products \\
\hline 216 & online opinion \\
\hline 217 & $\begin{array}{l}\text { online opinion-sharing } \\
\text { community }\end{array}$ \\
\hline
\end{tabular}

\begin{tabular}{|c|c|}
\hline No. & eWOM Alias \\
\hline 218 & online peer influence \\
\hline 219 & online posting \\
\hline 220 & online product rating \\
\hline 221 & online product review \\
\hline 222 & online product testimonial \\
\hline 223 & online recommendation \\
\hline 224 & online referral \\
\hline 225 & online reputation \\
\hline 226 & online review rating \\
\hline 227 & online review score \\
\hline 228 & online review sentiment \\
\hline 229 & online score \\
\hline 230 & online social influence \\
\hline 231 & online social interaction \\
\hline 232 & online social network \\
\hline 233 & online testimonial \\
\hline 234 & online text \\
\hline 235 & online user review \\
\hline 236 & online user-generated content \\
\hline 237 & online user-generated rating \\
\hline 238 & online user-generated review \\
\hline 239 & online user-generated WOM \\
\hline 240 & $\begin{array}{l}\text { online viral marketing } \\
\text { campaign }\end{array}$ \\
\hline 241 & online voice \\
\hline 242 & online WOM activity \\
\hline 243 & online WOM communication \\
\hline 244 & online WOM referral \\
\hline 245 & online word of mouth \\
\hline 246 & $\begin{array}{l}\text { online word-of-mouth } \\
\text { information }\end{array}$ \\
\hline 247 & $\begin{array}{l}\text { online word-of-mouth via } \\
\text { consumer-generated product } \\
\text { reviews }\end{array}$ \\
\hline 248 & opinion-sharing community \\
\hline 249 & OWOM \\
\hline 250 & peer comment \\
\hline 251 & $\begin{array}{l}\text { peer communication about } \\
\text { products via social media }\end{array}$ \\
\hline 252 & peer feedback \\
\hline 253 & peer information \\
\hline 254 & peer online opinion \\
\hline 255 & $\begin{array}{l}\text { peer-to-peer community } \\
\text { recommendation }\end{array}$ \\
\hline 256 & peer-to-peer message \\
\hline 257 & personalized referral \\
\hline 258 & $\begin{array}{l}\text { person-to-person } \\
\text { recommendation }\end{array}$ \\
\hline 259 & $\begin{array}{l}\text { person-to-person word of } \\
\text { mouth advertising }\end{array}$ \\
\hline 260 & polarity score \\
\hline 261 & population buzz \\
\hline 262 & post-release buzz \\
\hline 263 & pre-release buzz \\
\hline
\end{tabular}




\begin{tabular}{|c|c|}
\hline No. & eWOM Alias \\
\hline 264 & product comment \\
\hline 265 & product rating \\
\hline 266 & product recommendation \\
\hline 267 & product reference in blogs \\
\hline 268 & product review \\
\hline 269 & product review information \\
\hline 270 & $\begin{array}{l}\text { product-related word-of- } \\
\text { mouth conversation }\end{array}$ \\
\hline 271 & $\begin{array}{l}\text { promotional chat on the } \\
\text { internet }\end{array}$ \\
\hline 272 & purchase eWOM \\
\hline 273 & qualified buzz \\
\hline 274 & $\begin{array}{l}\text { quantified online consumer } \\
\text { review }\end{array}$ \\
\hline 275 & rating \\
\hline 276 & rating of consumers \\
\hline 277 & $\begin{array}{l}\text { rating of online consumer } \\
\text { review }\end{array}$ \\
\hline 278 & rating of online review \\
\hline 279 & $\begin{array}{l}\text { ratings and comments by } \\
\text { fellow consumers }\end{array}$ \\
\hline 280 & ratings from online forums \\
\hline 281 & $\begin{array}{l}\text { recommendation on the } \\
\text { Internet }\end{array}$ \\
\hline 282 & reference in blogs \\
\hline 283 & reputation \\
\hline 284 & reputation feedback \\
\hline 285 & reputation in social media \\
\hline 286 & reputation system \\
\hline 287 & retailer-hosted WOM \\
\hline 288 & review \\
\hline 289 & review comment \\
\hline 290 & review from buyers \\
\hline 291 & review information \\
\hline 292 & review on products \\
\hline 293 & review post \\
\hline 294 & salience of valence \\
\hline 295 & score \\
\hline 296 & seller average reputation \\
\hline 297 & seller rating \\
\hline 298 & sentiment \\
\hline 299 & social data \\
\hline 300 & social discussion \\
\hline 301 & social earned media \\
\hline 302 & social influence \\
\hline 303 & social interaction \\
\hline 304 & social media \\
\hline 305 & $\begin{array}{l}\text { social media consumer } \\
\text { conversation }\end{array}$ \\
\hline 306 & social media content \\
\hline 307 & social media conversation \\
\hline 308 & social media discussion \\
\hline 309 & $\begin{array}{l}\text { social media peer } \\
\text { communication }\end{array}$ \\
\hline 310 & social media post \\
\hline
\end{tabular}

\begin{tabular}{|c|c|}
\hline No. & eWOM Alias \\
\hline 311 & social network \\
\hline 312 & social network site \\
\hline 313 & $\begin{array}{l}\text { social network-based } \\
\text { recommendation }\end{array}$ \\
\hline 314 & social publishing \\
\hline 315 & $\begin{array}{l}\text { social referral within social } \\
\text { network }\end{array}$ \\
\hline 316 & social sharing \\
\hline 317 & social tag metric \\
\hline 318 & social voice \\
\hline 319 & social word of mouth \\
\hline 320 & social-network referral \\
\hline 321 & social-network WOM \\
\hline 322 & star rating \\
\hline 323 & star review \\
\hline 324 & sWOM \\
\hline 325 & third-party review \\
\hline 326 & tourist-generated content \\
\hline 327 & tweet \\
\hline 328 & UGC \\
\hline 329 & $\begin{array}{l}\text { unpaid brand impression on } \\
\text { Facebook }\end{array}$ \\
\hline 330 & unpaid market communication \\
\hline 331 & user eWOM \\
\hline 332 & user feedback \\
\hline 333 & user opinion \\
\hline 334 & user post \\
\hline 335 & user rating \\
\hline 336 & user recommendation \\
\hline 337 & user review \\
\hline 338 & user WOM interaction \\
\hline 339 & user word of mouth \\
\hline 340 & $\begin{array}{l}\text { user-contributed online } \\
\text { content }\end{array}$ \\
\hline 341 & user-created content \\
\hline 342 & user-generated advertising \\
\hline 343 & user-generated content \\
\hline 344 & $\begin{array}{l}\text { user-generated content in the } \\
\text { form of eWOM }\end{array}$ \\
\hline 345 & $\begin{array}{l}\text { user-generated feedback } \\
\text { review }\end{array}$ \\
\hline 346 & user-generated media \\
\hline 347 & $\begin{array}{l}\text { user-generated online product } \\
\text { review }\end{array}$ \\
\hline 348 & user-generated online review \\
\hline 349 & $\begin{array}{l}\text { user-generated online word- } \\
\text { of-mouth information }\end{array}$ \\
\hline 350 & $\begin{array}{l}\text { user-generated product } \\
\text { information on the Internet }\end{array}$ \\
\hline 351 & user-generated social media \\
\hline 352 & user-generated WOM \\
\hline 353 & $\begin{array}{l}\text { user-generated word-of-mouth } \\
\text { activity }\end{array}$ \\
\hline 354 & $\begin{array}{l}\text { user-generated word-of-mouth } \\
\text { interaction }\end{array}$ \\
\hline 355 & valence \\
\hline
\end{tabular}

\begin{tabular}{|c|c|}
\hline No. & eWOM Alias \\
\hline 356 & variance \\
\hline 357 & viral ad \\
\hline 358 & $\begin{array}{l}\text { viral advertising message on } \\
\text { social networking site }\end{array}$ \\
\hline 359 & viral buzz \\
\hline 360 & viral marketing \\
\hline 361 & virtual community \\
\hline 362 & virtual community post \\
\hline 363 & virtual eWOM review \\
\hline 364 & virtual public \\
\hline 365 & virtual review \\
\hline 366 & virtual word of mouth \\
\hline 367 & volume \\
\hline 368 & $\begin{array}{l}\text { web of things } \\
\text { recommendation }\end{array}$ \\
\hline 369 & web user comment on product \\
\hline 370 & web user WOM \\
\hline 371 & web-based brand community \\
\hline 372 & weblog post \\
\hline 373 & $\begin{array}{l}\text { WOM communication in the } \\
\text { context of the Internet and } \\
\text { online communities }\end{array}$ \\
\hline 374 & $\begin{array}{l}\text { WOM information on the } \\
\text { Internet }\end{array}$ \\
\hline 375 & WOM referral \\
\hline 376 & word of mouse \\
\hline 377 & word of mouth by consumers \\
\hline 378 & $\begin{array}{l}\text { word of mouth } \\
\text { communication }\end{array}$ \\
\hline 379 & word of mouth in social media \\
\hline 380 & $\begin{array}{l}\text { word of mouth marketing on } \\
\text { online social blogs }\end{array}$ \\
\hline 381 & $\begin{array}{l}\text { word of mouth on social- } \\
\text { networking sites }\end{array}$ \\
\hline 382 & word of mouth on the Internet \\
\hline 383 & $\begin{array}{l}\text { word of mouth within online } \\
\text { communities }\end{array}$ \\
\hline 384 & word of web \\
\hline 385 & word-of-mouth activity \\
\hline 386 & word-of-mouth conversation \\
\hline 387 & word-of-mouth information \\
\hline 388 & word-of-mouth interaction \\
\hline 389 & $\begin{array}{l}\text { word-of-mouth on online } \\
\text { social sites }\end{array}$ \\
\hline 390 & $\begin{array}{l}\text { word-of-web recommendation } \\
\text { within virtual consumer } \\
\text { communities }\end{array}$ \\
\hline
\end{tabular}




\section{Web Appendix 5}

Theoretical and methodological approaches used to study eWOM (1996-2019)

\begin{tabular}{|c|c|c|c|}
\hline & eWOM Creation & eWOM Exposure & eWOM Evaluation \\
\hline Investigated in ... & $51 \%$ articles & $31 \%$ articles & $81 \%$ articles \\
\hline $\begin{array}{l}\text { Theories used to } \\
\text { study the eWOM } \\
\text { phenomenon }\end{array}$ & $\begin{array}{l}\text { - Agglomeration theory } \\
\text { (Marshall 1920) } \\
\text { - } \quad \text { Uses and gratifications } \\
\text { theory (Katz and Foulkes } \\
\text { 1962) } \\
\text { - } \quad \text { Theory of WOM } \\
\text { involvement (Dichter } \\
\text { 1966) } \\
\text { - Social network theory } \\
\text { (Granovetter 1973) } \\
\text { - Theory of reasoned } \\
\text { action (Ajzen and } \\
\text { Fishbein 1980) }\end{array}$ & $\begin{array}{l}\text { - Accessibility-diagnosticity } \\
\text { theory (Kanouse and } \\
\text { Hanson 1972) } \\
\text { - Uncertainty reduction } \\
\text { theory (Berger and } \\
\text { Calabrese 1975) } \\
\text { - Conformity theory, a.k.a. } \\
\text { information cascades } \\
\text { theory (Akerlof 1980; Asch } \\
\text { 1956) } \\
\text { - Technology acceptance } \\
\text { model (Davis 1989) }\end{array}$ & $\begin{array}{ll}\text { - } & \text { Source credibility theory (Hovland et al. 1953) } \\
\text { - } & \text { Attribution theory (Kelley 1967) } \\
\text { - } & \text { Expectancy-disconfirmation theory (Anderson } \\
\text { 1973) } \\
\text { - } \quad \text { Flow theory (Csikszentmihalyi 1975) } \\
\text { - } & \text { Social exchange theory (Emerson 1976) } \\
\text { - } & \text { Dual-process theory of information processing } \\
\text { - } & \text { (Bettman and Park 1980; Petty and Cacioppo 1986) } \\
\text { - } & \text { Media richness theory (Daft and Lengel 1986) } \\
\text { - } & \text { Signaling theory (Boulding and Kirmani 1993; } \\
\text { - } & \text { Arbany 1986) } \\
\text { - } & \text { Cognitive fit theory (Vessey and Galletta 1991) } \\
\text { - } & \text { Regulatory focus theory (Higgins 1997) } \\
\text { - } & \text { (Temporal) construal theory (Liberman and Trope } \\
& \text { 1998) }\end{array}$ \\
\hline $\begin{array}{l}\text { Methodologies } \\
\text { used to study the } \\
\text { eWOM } \\
\text { phenomenon }\end{array}$ & $\begin{array}{ll}\text { - } & 6 \% \text { Conceptual } \\
\text { - } & 4 \% \text { Experimental } \\
\text { - } & 12 \% \text { Qualitative } \\
\text { - } & 25 \% \text { Modeling } \\
\text { - } & 4 \% \text { Mixed }\end{array}$ & $\begin{array}{ll}\text { - } & 4 \% \text { Conceptual } \\
\text { - } & 2 \% \text { Experimental } \\
\text { - } & 8 \% \text { Qualitative } \\
\text { - } & 15 \% \text { Modeling } \\
\text { - } & 2 \% \text { Mixed }\end{array}$ & $\begin{array}{ll}\text { - } & \text { 8\% Conceptual } \\
\text { - } & 14 \% \text { Experimental } \\
\text { - } & 13 \% \text { Qualitative } \\
\text { - } & 40 \% \text { Modeling } \\
\text { - } & 6 \% \text { Mixed }\end{array}$ \\
\hline
\end{tabular}

Note: This table reports the most common, landmark theoretical frameworks and methodological approaches applied in eWOM scholarship between 1996 and 2019 . All percentages are calculated to the total number of articles $(1,050)$. 


\section{References for theories cited in Web Appendix 5}

Ajzen, I., \& Fishbein, M. (1980). Understanding attitudes and predicting behavior. Englewood Cliffs, NJ: Prentice Hall.

Akerlof, G.A. (1980). A theory of social custom, of which unemployment may be one consequence. Quarterly Journal of Economics, 94(4), 749-775.

Anderson, R.E. (1973). Consumer dissatisfaction: The effect of disconfirmed expectancy on perceived product performance. Journal of Marketing Research, 10(1), 38-44.

Asch, S.E. (1956). Studies of independence and conformity: A minority of one against a unanimous majority. Psychological Monographs, 70(416), 1-70.

Berger, C., \& Calabrese, R.J. (1975). Some explorations in initial interactions and beyond: Towards a developmental theory of interpersonal communication. Human Communication Research, 1, 99-112.

Bettman, J.R., \& Park, C.W. (1980). Effects of prior knowledge and experience and phase of the choice process on consumer decision processes: A protocol analysis. Journal of Consumer Research, 7(3), 234-248.

Boulding, W., \& Kirmani, A. (1993). A consumer-side experimental examination of signaling theory: Do consumers perceive warranties as signals of quality? Journal of Consumer Research, 20(1), 111-123.

Csikszentmihalyi, M. (1975). Beyond boredom and anxiety. San Francisco: Jossey-Bass Publishers.

Daft, R. \& Lengel, R.H. (1986). Organizational information requirements, media richness, and structural design. Management Science, 32(5), 554-571.

Davis, F.D. (1989). Perceived usefulness, perceived ease of use, and user acceptance of information technology. MIS Quarterly, 13(3), 319-340.

Dichter, E. (1966). How word-of-mouth advertising works. Harvard Business Review, 44(6), 147-166.

Emerson, R.M. (1976). Social exchange theory. Annual Review of Sociology, 2(1), 335-362.

Granovetter, M.S. (1973). The strength of weak ties. American Journal of Sociology, 78(6), 1360-1380.

Higgins, E.T. (1997). Beyond pleasure and pain. American Psychologist, 52(12), 1280-300.

Hovland, C.I., Janis, I.I., \& Kelley, H.H. (1953). Communication and Persuasion. New Haven: Yale University Press.

Kanouse, D.E. \& Hanson, L.R. (1972). Negativity in evaluations. In Attribution: Perceiving the causes of behavior, NJ: General Learning Press.

Katz, E., \& Foulkes, D. (1962). On the use of the mass media as “escape”: Clarification of a concept. Public Opinion Quarterly, 26(3), 377-388.

Kelley, H.H. (1967). Attribution theory in social psychology. In D. Levine (Ed.), Nebraska symposium of motivation, Vol. 15 (pp. 192-238). Lincoln: University of Nebraska Press.

Latané, B. (1981). The Psychology of Social Impact. American Psychologist, 36(4), 343-356.

Latour, B. (1990). Technology is society made durable. The Sociological Review, 38(1), 103-131.

Liberman, N., \& Trope, Y. (1998). The role of feasibility and desirability considerations in near and distant future decisions: A test of temporal construal theory. Journal of Personality and Social Psychology, 75(1), 5-18.

Marshall, A. (1920). Principles of economics, 8th ed. London: Macmillan.

Petty, R.E., \& Cacioppo, J.T. (1986). The elaboration likelihood model of persuasion. In Communication and persuasion (pp. 1-24). Springer.

Tversky, A., \& Kahneman, D. (1974). Judgment under uncertainty: Heuristics and biases. Science, 185(4157), 1124-1131.

Urbany, J. E. (1986). An experimental examination of the economics of information. Journal of Consumer Research, 13(2), 257-271.

Vessey, I., \& Galletta, D. (1991). Cognitive fit: An empirical study of information acquisition. Information Systems Research, 2(1), 63-84. 